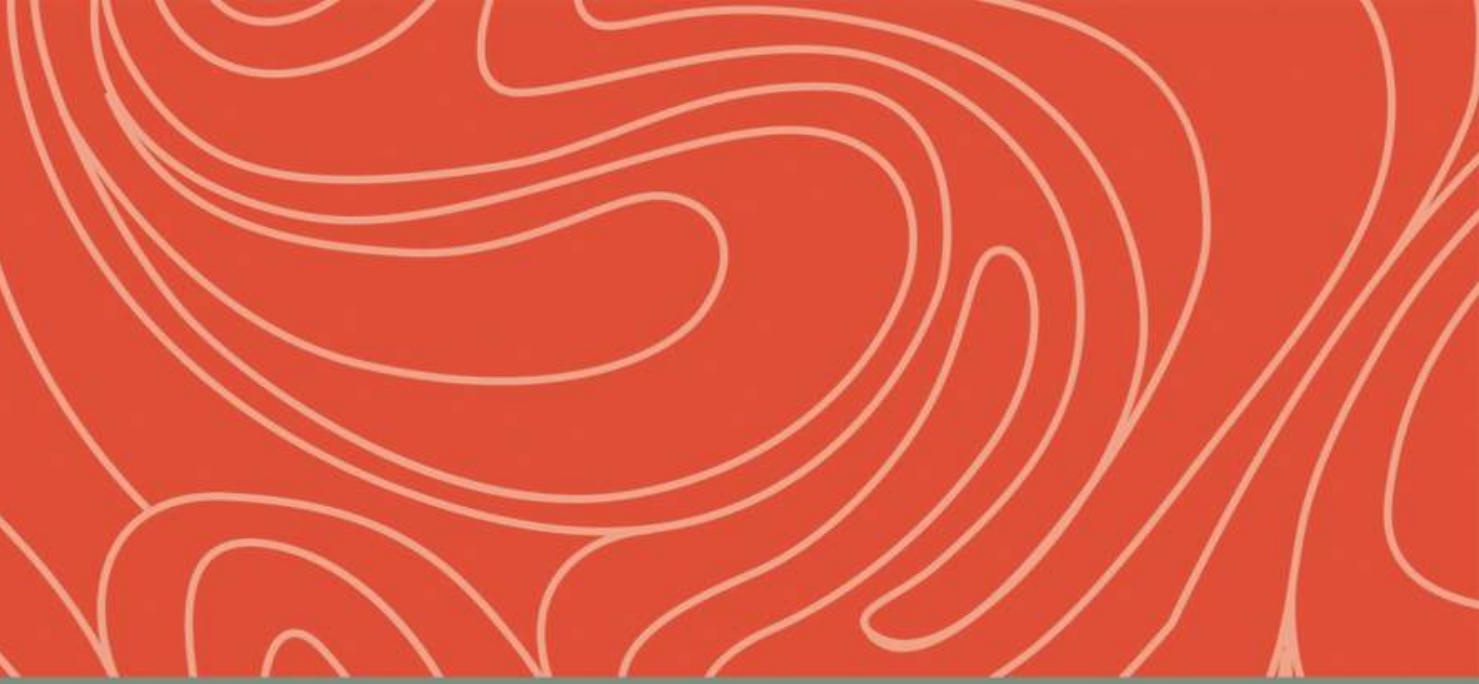

Routledge Studies in Gender and Global Politics

\title{
GENDER EQUALITY AND NATION BRANDING IN THE NORDIC REGION
}

Edited by

Eirinn Larsen, Sigrun Marie Moss and Inger Skjelsbæk

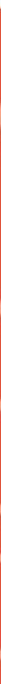




\section{Gender Equality and Nation Branding in the Nordic Region}

This book explores how gender equality, a central part of the Nordic imaginary, is used in the political communication of Nordic states. The analyses presented move beyond conventional images and discourses of Nordic gender- and women-friendliness by critically investigating how and to what extent gender equality serves nation-branding in the Nordic region.

Nation-branding is an unescapable part of globalisation, which is a market-oriented process dominated by the West and predicated on the creation of winners and losers. Hence, efforts to strengthen the national brand or reputation of specific Nordic countries with the aid of gender equality as a political and symbolic value inevitably help to reinforce already established global hierarchies where the Nordics play the role of moral superpower. This book comprises scholars from various fields of specialisation, and provides evidence and understanding for the growing interaction between gender-equality policies and nation-branding in all five Nordic countries. It does so by exploring a variety of policy fields and issues including women's rights, foreign policy, rape and legislation, female quotas and business policies, in addition to the index industry. The rise of the global indexes has reproduced forceful images of the Nordic countries as frontrunners of gender equality, which indeed help the Nordic countries to further position themselves as 'best at being good'.

This book will be of great interest to students and scholars of Nordic gender equality in political science, sociology, law, criminology, political psychology and history, as well as those interested in nation-branding, Nordic studies and exceptionalism.

Eirinn Larsen is Professor of History in the Department of Archaeology, Conservation and History at the University of Oslo, Norway.

Sigrun Marie Moss is Associate Professor in the Department of Psychology at the University of Oslo, Norway.

Inger Skjelsbak is Professor at the Center for Gender Research and the Center for Research on Extremism at the University of Oslo, Norway. 


\section{Routledge Studies in Gender and Global Politics \\ Series Editor: Laura J. Shepherd, University of Sydney, Australia}

This series aims to publish books that work with, and through, feminist insights on global politics, and illuminate the ways in which gender functions not just as a marker of identity but also as a constitutive logic in global political practices. The series welcomes scholarship on any aspect of global political practices, broadly conceived, that pays attention to the ways in which gender is central to, (re)produced in, and is productive of, such practices.

There is growing recognition both within the academy and in global political institutions that gender matters in and to the practices of global politics. From the governance of peace and security, to the provision of funds for development initiatives, via transnational advocacy networks linked through strategic engagement with new forms of media, these processes have a gendered dimension that is made visible through empirically grounded and theoretically sophisticated feminist work.

Civil Society, Care Labour, and the Women, Peace and Security Agenda Making 1325 Work

Caitlin Hamilton, Anuradha Mundkur and Laura J. Shepherd

Gender Equality and Nation Branding in the Nordic Region

Edited by Eirinn Larsen, Sigrun Marie Moss and Inger Skjelsbaek

\section{International Women's Rights Law and Gender Equality}

Making the Law Work for Women

Edited by Ramona Vijeyarasa

\section{Gender and Political Apology}

When the Patriarchal State Says "Sorry"

Emma Dolan

The European Union's International Promotion of LGBTI Rights

Promises and Pitfalls

Markus Thiel 


\title{
Gender Equality and Nation Branding in the Nordic Region
}

\author{
Edited by \\ Eirinn Larsen, Sigrun Marie Moss \\ and Inger Skjelsbak
}


First published 2021

by Routledge

2 Park Square, Milton Park, Abingdon, Oxon OX14 4RN

and by Routledge

605 Third Avenue, New York, NY 10158

Routledge is an imprint of the Taylor \& Francis Group, an informa business

(C) 2021 selection and editorial matter, Eirinn Larsen, Sigrun Marie

Moss and Inger Skjelsbæk; individual chapters, the contributors

The right of Eirinn Larsen, Sigrun Marie Moss and Inger Skjelsbæk

to be identified as the authors of the editorial material, and of the authors for their individual chapters, has been asserted in accordance with sections 77 and 78 of the Copyright, Designs and Patents Act 1988.

The Open Access version of this book, available at www.

taylorfrancis.com, has been made available under a Creative

Commons Attribution-Non Commercial-No Derivatives 4.0 license.

Trademark notice: Product or corporate names may be trademarks or registered trademarks, and are used only for identification and explanation without intent to infringe.

British Library Cataloguing-in-Publication Data

A catalogue record for this book is available from the British Library

Library of Congress Cataloging-in-Publication Data

Names: Enloe, Cynthia H., 1938- author. | Larsen, Eirinn, editor.|

Moss, Sigrun Marie, editor. | Skjelsbæk, Inger, editor.

Title: Gender equality and nation branding in the Nordic region /

edited by Eirinn Larsen, Sigrun Marie Moss and Inger Skjelsbæk.

Description: Abingdon, Oxon; New York, NY : Routledge, 2021. |

Series: Routledge studies in gender and global politics | Includes

bibliographical references.

Identifiers: LCCN 2021003247 (print) | LCCN 2021003248 (ebook) |

ISBN 9780367861353 (hardback) | ISBN 9781003017134 (ebook)

Subjects: LCSH: Women-Social conditions-Scandinavia.|

Place-marketing-Scandinavia.

Classification: LCC HQ1667.E55 2021 (print) | LCC HQ1667 (ebook) |

DDC 305.40948 - dc23

LC record available at https://lccn.loc.gov/2021003247

LC ebook record available at https://lccn.loc.gov/2021003248

ISBN: 978-0-367-86135-3 (hbk)

ISBN: 978-0-367-69293-3 (pbk)

ISBN: 978-1-003-01713-4 (ebk)

DOI: $10.4324 / 9781003017134$

Typeset in Times New Roman

by codeMantra 


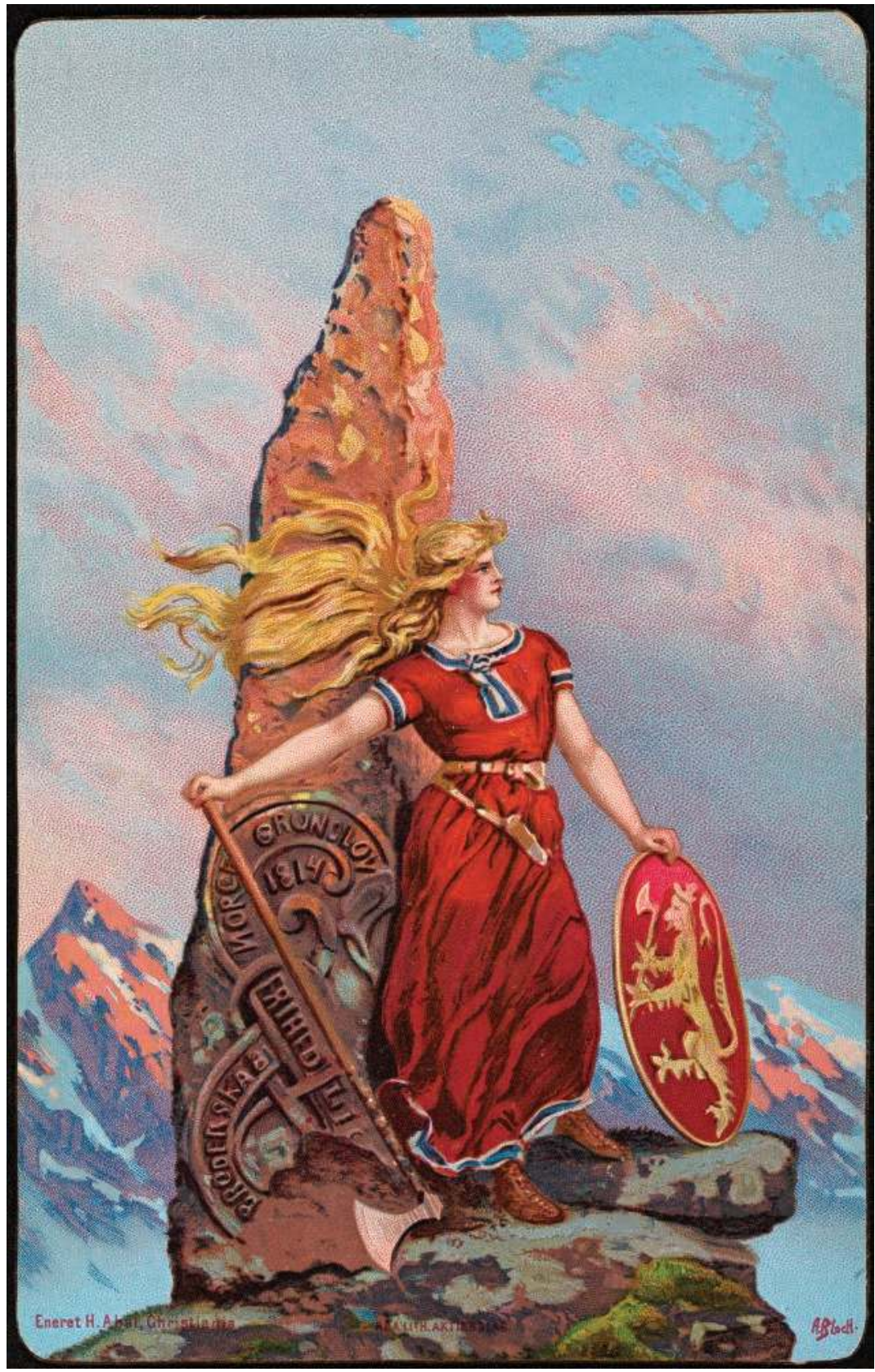

This picture shows "Mother Norway" who is a blond Valkyrie painted by Andreas Bloch in 1905 and symbolizes that it is women who decide who shall live and die in battle.

* Source: Artist: Andreas Bloch (1860-1917), used with permission of the National Library of Norway (owner institution). 

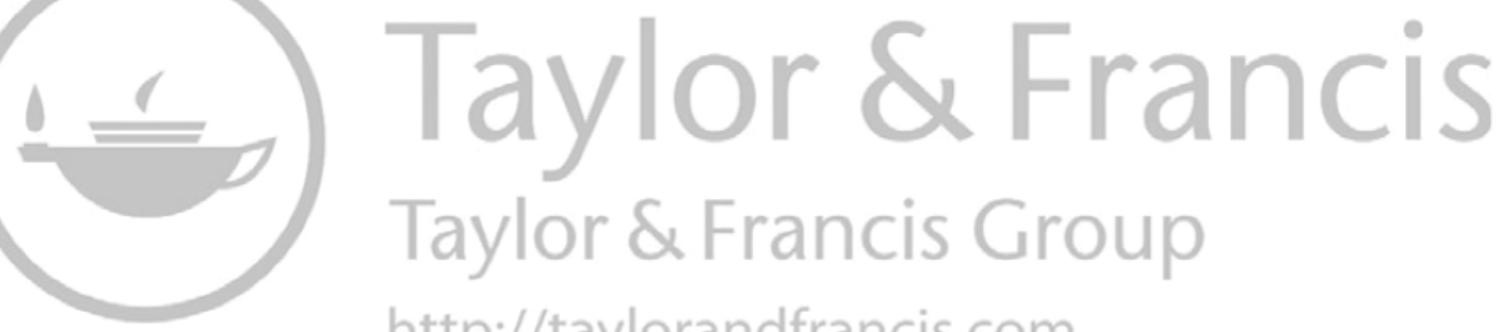

http://taylorandfrancis.com 


\section{Contents}

Notes on contributors ix

Foreword xiii

CYNTHIA ENLOE

Introduction 1

EIRINN LARSEN, SIGRUN MARIE MOSS AND INGER SKJELSBÆK

1 'The gender-progressive Nordics': A matter of history 13 EIRINN LARSEN

2 Variations on shared themes: Branding the Nordics as gender equal KATARZYNA JEZIERSKA AND ANN TOWNS

3 Applying the brand or not? Challenges of Nordicity and gender equality in Scandinavian diplomacy

SIGRUN MARIE MOSS

4 Keeping Sweden on top: Rape and legal innovation as nation-branding

MAY-LEN SKILBREI

5 Trouble in paradise? Icelandic gender-equality imaginaries, national rebranding and international reification

IRMA ERLINGSDÓTTIR

6 Protecting the brand? The hesitant incorporation of gender equality in the peace nation 


\section{viii Contents}

7 A useful tool? Images of the Nordics in Swiss quota debates STÉPHANIE GINALSKI

8 Silenced at the border: Norwegian gender-equality policies in national branding

CATHRINE HOLST AND MARI TEIGEN

9 Not so exceptional after all? Nordic gender equality and controversies linked to the Convention on the Elimination of All Forms of Discrimination Against Women

ANNE HELLUM

10 Creating gender exceptionalism: The role of global indexes

TORI LOVEN KIRKEB $\varnothing$, MALCOLM LANGFORD AND

HALDOR BYRKJEFLOT

Afterword: Gendering the brand? 


\section{Notes on contributors}

Haldor Byrkjeflot (b. 1959) is a Professor in the Department of Sociology and Human Geography at the University of Oslo, Norway. His research interests include the emergence and circulations of societal and organizational models, organization theory, bureaucracy and historical-comparative studies. He has published articles on comparative management, the globalization of the MBA, changing knowledge regimes in universities, comparative labour systems, the role of bureaucracy in modern societies and reforms and organizational dynamics in health and education.

Cynthia Enloe (b. 1932) is a Research Professor in the Department of International Development, Community, and Environment (IDCE), affiliated with Political Science and with Women's and Gender Studies, all at Clark University in Worcester, Massachusetts, USA. Her writings have been translated into Spanish, Turkish, French, Portuguese, Japanese, Korean, Czech, Swedish, Icelandic and German. She has published in Ms. magazine and the Village Voice, and appeared on National Public Radio, Al Jazeera, C-Span and the BBC.

Irma Erlingsdóttir (b. 1968) is a Professor at the University of Iceland and Director of the UNESCO-affiliated Gender Equality Studies and Training Programme (GRÓ- GEST); RIKK - Institute for Gender, Equality and Difference; and the EDDA Center in Contemporary Critical Research at the University of Iceland.

Stéphanie Ginalski (b. 1977) is a Swiss historian and Senior Lecturer at the University of Lausanne, Switzerland. Her main research interests are business elites, the transformation of capitalism during the twentieth century and corporate networks. She is a co-founder and member of the Swiss Elites Observatory (www.unil.ch/obelis).

Anne Hellum (b. 1952) is a Professor in the Department of Public and International Law at the University of Oslo, Norway. She was awarded the Dr. Juris Degree at the University of Oslo in 1998. She specializes in equality and anti-discrimination law, with a focus on the relationship between women's equal rights as individual citizens and as members of different 
social, ethnic and religious groups in Norwegian, Nordic and African contexts.

Cathrine Holst (b. 1974) is a Professor of Sociology at the University of Oslo, Norway. She is also connected to CORE - Centre for Research on Gender Equality at the Institute for Social Research, Oslo. Among Holst's research interests are democratic and political theory, the role of expert knowledge in policy-making and gender-equality policy.

Katarzyna Jezierska (b. 1979) is an Associate Professor of Political Science at University West, Sweden, and a Researcher at GenDip, University of Gothenburg, Sweden. Her research interests span democratic theory, civil society, policy advice and diplomacy, with an empirical focus on Central Europe.

Tori Loven Kirkebø (b. 1987) is a Research Fellow at the University of Oslo, Norway, and Coordinator for the UiO:Norden project 'Nordic Branding: Politics of Exceptionalism'. A political scientist, her research spans business and human rights, implementation and measurement/indexing of human rights, and empirical legal methods.

Malcolm Langford (b. 1972) is a Professor of Public Law at the University of Oslo, Norway, and leads the UiO:Norden project 'Nordic Branding: Politics of Exceptionalism'. He is also Director of the Centre on Experiential Legal Learning (CELL), a Centre of Excellence in Education (SFU), and Co-director of the Centre on Law and Social Transformation at the Chr. Michelsen Institute, Norway, and the University of Bergen, Norway. His publications span human rights and constitutionalism, international relations, investment and development, law and technology, and the politics of the legal profession.

Eirinn Larsen (b. 1969) is Professor of History in the Department of Archaeology, Conservation and History at the University of Oslo, Norway. She is Co-leader of the UiO:Norden project 'Nordic Branding: Politics of Exceptionalism'. Her publications span the history of business education and managerial elites in Europe during the nineteenth and twentieth centuries, women's entrepreneurship, suffrage and gender equality in the Nordic region, science policy and modern historiography.

Halvard Leira (b. 1976) is a Research Professor at the Norwegian Institute of International Affairs (NUPI). His varied research interests fall mainly within the field of historical international relations. He has published extensively in English and Norwegian on international political thought, historiography, conceptual history, foreign policy and diplomacy.

Sigrun Marie Moss (b. 1982) is Associate Professor in the Department of Psychology at the University of Oslo, Norway. She is associated with the UiO:Nordic project 'Nordic Branding: The Politics of Exceptionalism', 
where she focuses on gender equality in use and presentation in the Scandinavian ministries of foreign affairs. She is also interested in the methodological aspects involved in interviewing diplomats.

May-Len Skilbrei (b. 1971) is a Professor at and Head of the Department of Criminology and Sociology of Law at the University of Oslo, Norway. Her work revolves around sexuality, gender and law, and she currently heads a large multidisciplinary research project on the prosecution of rape.

Inger Skjelsbæk (b. 1969) is Professor at the Center for Gender Research and the Center for Research on Extremism at the University of Oslo, Norway. She is also a Research Professor in Peace and Conflict at the Peace Research Institute Oslo (PRIO). Her research has focused on the aftermath for survivors of conflict-related sexual violence and affected communities in Bosnia and Herzegovina, and on perpetrators of conflict-related sexual violence from Bosnia sentenced at the International Criminal Tribunal for the former Yugoslavia (ICTY).

Mari Teigen (b. 1963) is a Norwegian sociologist, Research Professor and Director of CORE - Centre for Research on Gender Equality at the Institute for Social Research, Oslo, Norway. Her research spans European gender-equality policies, social, corporate and political elites, and gendered labour markets.

Ann Towns (b. 1970) is a Professor of Political Science at the University of Gothenburg, Sweden, and a Wallenberg Academy Fellow. She leads GenDip, a research programme on gender in diplomacy (see https://www. gu.se/gendip), and was awarded a Bertha Lutz Prize by the International Studies Association in 2018. Her research focuses on diplomacy and gender, hierarchies, order and norms in international politics, and discourses of civilization in international politics.

Torunn L. Tryggestad (b. 1968) is a Norwegian political scientist and Senior Researcher at the Peace Research Institute Oslo (PRIO), Norway, where she is also Director of the PRIO Centre on Gender, Peace and Security. Her research specialization is in the UN and the Women, Peace and Security agenda, gender and peace processes, and gender and inclusive peace mediation. 

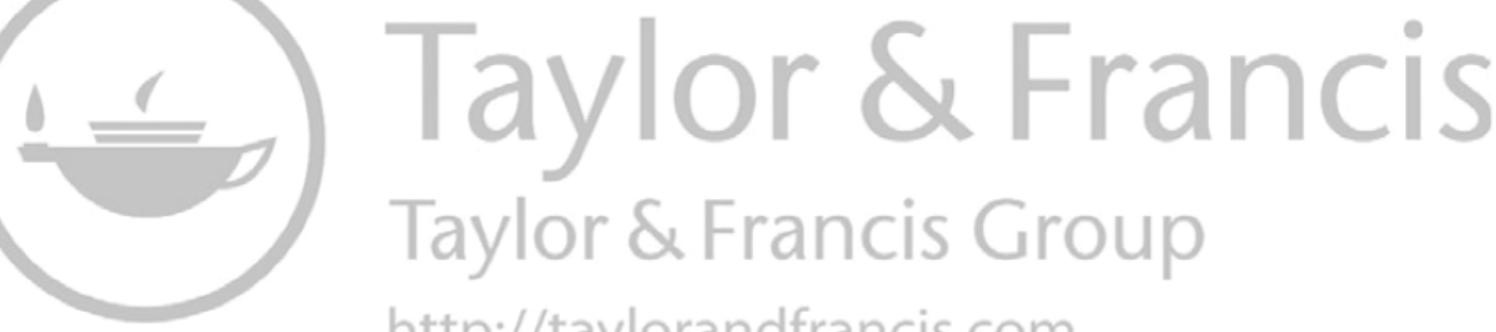

http://taylorandfrancis.com 


\section{Foreword}

We were sitting around the table after dinner, the red wine bottles not yet quite empty. The light-hearted banter turned to national stereotypes and the jokes people in each country told about each other. There were, I think, about six of us sharing the comfortable house, three train stations outside downtown Oslo. Most around the table were from Nordic countries. As a visiting researcher at the Peace Research Institute Oslo (PRIO), I was one of the two non-Nordics that evening. The other was a recent household arrival, a Turkish activist asylum-seeker, who now occupied the sofa in the front room. The laughter grew boisterous as people chimed in with examples from Finnish and Norwegian television shows and with witty, though not mean, regional jokes learned in schoolyards.

I was fascinated. Until then, I had lumped the countries of the Nordic region together. I probably even mistakenly labelled all five 'Scandinavian'.

This would have been October 1978.

Now, here we are in 2020. Over these last four decades, I have learned to say 'Nordic' when referring to the five northern countries. Over the same decades, Icelandic voters have chosen the world's first woman elected head of state; Norway's members of parliament have voted to conscript young women as well as young men in the country's military; a Swedish foreign minister has declared her commitment to a feminist foreign policy; the governments of Demark and Finland, each headed by women prime ministers, have received high marks for their public responses to the coronavirus pandemic - and, we learn from this fascinating book, 'Nordic' has been turned into a brand.

As I've been reading these engaging chapters, I've been pushed (I like being intellectually pushed!) to think carefully about the interplay of four central themes that take centre stage here. First, there are the politics of branding. I've wondered about gendered branding ever since I started exploring Chiquita's corporate campaign to brand a generic fruit, the banana. But taking deliberate steps to brand an entire geographic region - that is new to me. Second, there is the centrality of gender equality - as a reality and a civic commitment - to this deliberately constructed Nordic brand. Third, the contributors to this volume remind us, we have to grapple with this messy

DOI: $10.4324 / 9781003017134$ 
reality: despite Nordic branding efforts, the five countries have remained quite distinct, even in their allegedly shared gender-equality successes (for example, only Sweden uses 'feminist' in its official self-description). The five aren't quite the stereotypes that made my Oslo friends laugh out loud all those years ago, but they certainly are not carbon copies of each other. And, fourth, the authors reveal, there are both advantages and disadvantages to positive regional branding. A downside, it turns out, is that presenting oneself as ahead of everyone else can be quite off-putting for one's potential allies and partners.

These attentive contributors reveal, moreover, that the four dynamics are neither stable over time nor simply moving along on parallel tracks.

There is a good reason why this book is more valuable analytically for being written by gender specialists. Since the 1970s, each of the five Nordic countries has been pushed by its local women's movements to face up to, and address politically, the masculinizing processes that shaped each of their structures and cultures of business, family, politics and culture. Those five women's movements have not moved in lock step; their activists, I've learned, don't share a common regional language, and thus often can only talk to each other in English. Iceland's 1975 historic Women's Strike has not been repeated in the other four countries. The pressures to absorb new immigrants and address local racism and ethnocentrism have not been uniformly felt by feminists in all five societies. Notwithstanding these differences among women's movements, there have been shared activist experiences and conscious collaborations, as well as, as we see here, joint research enterprises. The contributors to this volume show us how those myriad sharings have worked their ways into a notable regional branding effort, an effort enacted not just by women activists, but by people who have come to see gender equality - or at least the veneer of gender equality - as useful for pursuing their own ends.

And all this has made me realize how much gender investigating we all still need to do. Thanks to the focused and rigorous investigations offered here, the editors and scholars involved in this work have made me more curious about the micro-workings of masculinities and femininities - and thus of patriarchy in all its guises. I'm greedy. Having now finished these eye-opening chapters, I want full gender analyses of every one of the Nordic ministries of foreign affairs. Furthermore, the gender workings of the full process of designing, approving and revising national websites have now caught my attention. I am also looking forward to someone conducting a feminist gender analysis of the Norwegian Tourism Board - maybe a team to compare the genderings of all five countries' tourism boards. I've become more curious, too, to see the findings of researchers who dig into the gender dynamics shaping the day-to-day relationships between business lobbyists and the Danish and Finnish ministries of foreign affairs. 
Foreword xv

Yes, I know. It does seem ungrateful of me to write a foreword that asks for more. But, really, that is the sign of an analytically valuable book, isn't it? These authors have left me wanting more.

Cynthia Enloe Cambridge, Massachusetts 12 September 2020 

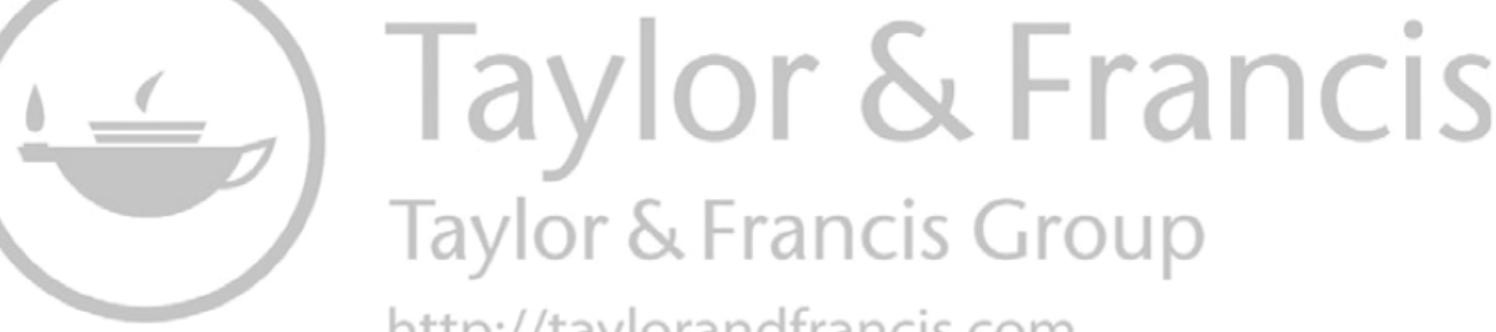

http://taylorandfrancis.com 


\title{
Introduction
}

\author{
Eirinn Larsen, Sigrun Marie Moss \\ and Inger Skjelsbak
}

Gender equality is an inevitable part of the Nordic imaginary - and partly for unmistakable reasons: The Nordic states enfranchised women ahead of most countries and regions in the world. And since the social transformations of the 1970s, the Nordics have all introduced generous welfare programmes and policies to overcome inequalities deriving from longstanding structures and cultures of gender difference. At the same time, there is reason to ask what role this predominantly progressive gender image currently plays in the political communication of the Nordic states abroad. Particularly in a time when branding has become a 'necessary marker of identification, a language for all nations on a global scale' (Aronczyk, 2018: 233), we need to investigate more critically the strategic use of gender equality in the Nordic region for the purposes of nation-branding and reputation management.

The Nordic countries top the rankings of all global indexes on gender equality. Their global reputation is underlined by the United Nations' description of Norway as a 'haven of gender equality' (UN CEDAW, 2003), while others have proclaimed them 'gender superpowers' (Vandapuye, 2016). ${ }^{1}$ The circulating force of these simplistic representations seems evident in a time when the political interaction within and between states increasingly takes place on Twitter, social media and the internet. Yet to portray the Nordic countries as forerunners or superpowers of gender equality is never an objective or neutral act, but the result of agency: of states, parliamentarians, politicians, civil society, NGOs or other interest groups, in addition to media and communication professionals. It is therefore important to ask not only what role the Nordic gender imaginary currently plays in the external communication of the Nordic region, but by whom the Nordic gender image is mobilized, for what purpose, and how the strategic use of gender equality has affected the brands of the region's five countries: Denmark, Sweden, Norway, Finland and Iceland. Further, if the Nordic brand has been successfully gendered, how does the individual Nordic country manage to differentiate itself from its fellow Nordic comrades by representing itself as a gender-equal nation? This is the core focus of this book on gender equality and nation branding in the Nordic region. 


\section{Moving beyond Nordic gender exceptionalism}

This book, put together by scholars from various fields of specialization, is motivated by an urge to move beyond conventional images and discourses of Nordic gender- and women-friendliness. At a time when nation-branding is regarded as vital for the global recognition of states, it seems even more important to shed a critical light on how and to what extent the Nordic countries draw on the Nordic gender image to enhance their own visibility in the world. Current attempts to brand the nation - also called nationbranding - involve efforts to create new or reinforce already existing associations and identities of the nation as a geographical, historical, cultural, political, economic and social entity. This is usually done by triggering or nourishing its positive values and associations to distinguish it from other countries on the global scene (Vuignier, 2016: 9). Nation-branding is thus also an unescapable part of globalization, which is a market-oriented process dominated by the West and predicated on the creation of winners and losers. Hence, efforts to strengthen the national brand or reputation of individual Nordic countries with the aid of gender equality as a political and symbolic value inevitably help to reinforce already established global hierarchies of the Nordics as moral superpowers.

When Nordic ministers or academic observers proclaim that the Nordics are 'gender superpowers', ${ }^{2}$ the images of gender equality are usually closely related to Nordic achievements and experiences within the welfare state, including stay-at-home dads and parental leaves. This indicates that gender equality also has become essential to the self-understandings of the Nordic countries, serving as a source of pride and national identity, and defined as a key element of economic prosperity and a well-functioning society. Nordic uniqueness on gender therefore tends to inflect and legitimate other aspects of the Nordic models, such as the Nordic model of welfare and social democracy.

This book addresses some of these intricate and sometimes complicated interactions between domestic self-identification and foreign promotion and projection of the Nordic models, regions and countries. Consequently, it leans more on the fast-growing scholarship of nation-branding and reputation management than on the literature on nation-building, although it does acknowledge the importance of national identities for nation-branding purposes. Few, if any, states brand themselves in stark opposition to how they see themselves domestically. But where nation-building has some room for idiosyncrasies and complexities, the market language of branding calls for simplicity to the level of distortion. It feels somehow important to state that we, as editors and authors of this book, do not necessarily identify with the processes discussed and analysed in its pages. For us, branding - including nation-branding - has foremost been an analytical tool to unlock the apparent ones of our own time, that is, concerns of how states present themselves to the outside world and the decoupling that often follows between what 
takes place at home, politically speaking, and what is promoted abroad. The danger of turning gender equality into a political symbol or brand is, of course, that this might lead to a sense that there is no need for improvement. The political force of gender equality as a normative value and vigour in society runs, in this way, the danger of ebbing out. The contribution of this book is more about the empirical richness of its ten chapters than its critique of nation-branding as theory and practice. The book shows how gender equality has been and is currently being used in the political communications of the Nordic countries. We draw upon empirical studies of Nordic domestic self-images within different areas, as well as external imaginings and uptakes of the Nordic gender imaginary within various policy fields.

In recent decades, the image of the Nordic countries as gender champions has circulated in and out of the Nordic region thanks to the global index industry, the media, and social science researchers like ourselves publishing internationally on various gender-related themes. In this book, however, we focus on three key actors - national governments, business organizations and civil society - without losing sight of the vast international literature on the Nordic model(s), on the one hand, and nation-branding, on the other. The process of imagining the Nordics as gender-progressive, as already stated, is closely related to the discourse of Nordic exceptionalism built on the notion of the 'Nordic models' (Browning, 2007; Clerc et al., 2015; Marklund, 2017). This scholarly literature and discourse focuses predominantly on social welfare, labour relations, penal culture and law, development aid, Nordic cuisine and aesthetics, the 'Nordic ways of doing things', and the general stickiness of the Nordic reputation (Marklund and Petersen, 2013; Skilbrei and Holmström, 2013; Ridderheim, 2014; Jónsson, 2014; Elgström and Delputte, 2016; Leer, 2016; Scharff Smith and Ugelvik, 2016; Solum, 2016; Stougaard-Nielsen, 2016). Few systematic efforts, however, have been made to bring gender into the expanding critical literature on nation-branding in the Nordic area (for exceptions, see Towns, 2002; Loftsdóttir, 2015; Jezierska and Towns, 2018; Einarsdóttir, 2020).

In their contribution to the emerging literature on public diplomacy and nation-branding in the Nordic region, Clerc and Glover (2015: 6) distinguish between domestic imaginings of the nation and the external imaging of it. In doing so, they optimize the delicate but ever so mutually dependent relationship between nation-building and nation-branding. In his seminal work Imagined Communities: Reflections on the Origin and Spread of Nationalism, Benedict Anderson (1983) saw nations as imagined communities; communities that were made possible as print capitalism in the sixteenth century created new ways of communicating identity and belonging among citizens. Nation-building and nation-branding can thus be said to have the imaginary aspect in common, yet as historical phenomena they must be kept apart. It was during the neoliberal turn of the late 1970s and early 1980s that business principles and communication strategies entered state management in the form of nation-branding, including in the realm of public policy-making. 
Nation-building, on the other hand, goes back to the nineteenth century and the rise of new nation-states, including in the Nordic region, defined by their distinct languages, cultures and pasts. In this sense, nations were de facto brands long before more systematic efforts began to cultivate certain of the nation's associations for nation-branding or reputation-management purposes, whether the aim of such activity is to attract foreign investment, to secure a chair at the table of powerful organizations or to increase the visibility of a country in the international arena.

Our book builds on Clerc and Glover's distinction between, on the one hand, domestic imagining of the Nordic countries related to ongoing processes of nation-building and, on the other, foreign or external imaging of the areas in question. The external pictures made of the Nordic region and countries are more detached from the national identity politics of the Nordic countries. At the same time, we recognize the danger of operating on the assumption that a watertight separation can be maintained between the two sides of the distinction. Activities of imagining and imaging the Nordics take place both inside and outside the region, and it is our task to capture some of the dynamics at play between various branding agents at the same time as we allow the actors studied to define and name their own activities. Thus, in this book, we deliberately recognize the multi-faceted nature of nation-branding, even when studying periods before the neoliberal turn of the 1980s and 1990s. That said, we are fully aware that nation-branding is a contemporary phenomenon and that most would read this book with that sense in mind, not necessarily viewing it as an analytical lens, as we have made use of it.

\section{Nation-branding versus nation brands}

There is considerable variation in the definitions of nation-branding, and many related concepts - such as public diplomacy, framing and reputation management, and status-seeking - are linked to the phenomenon it captures. The authors of this book have been given room to situate themselves and their topics in the broader scope of nation-branding and related conceptualizations, as we believe these different terms speak to the imagining of the Nordic in relation to gender equality. Again, this makes branding first and foremost an analytical device for grasping contemporary and past representations of the Nordics in relation to gender equality (Langford and Larsen, 2017; Viktorin et al., 2018: 11-20). We also relate to nation-branding as a contemporary phenomenon and characteristic of the neoliberal state (Varga, 2013). The practice of branding, however, is much older, first used in the Bronze Age to mark ownership, particularly of cattle. Etymologically speaking, the word brand originates from the Old Norse brandr, which simply means to burn with something hot - such as charred wood or iron. In the nineteenth century, branding turned into a business practice used to appeal to the consumer and to help sell increasingly similar products. The 
rise of department stores from the 1830 s onwards represented a revolution in retailing, offering a large range of goods for fixed prices, which made it increasingly important to provide each product with a unique image and personality. Yet it was the explosion of mass consumption during the 1950s and 1960s that helped branding become a tool of modern marketing, strategically used both for products and for cities and countries to attract buyers and tourists. The goal of branding, however, is to create a brand that, if it proves successful, provides strong associations with the product itself, such as Apple for computers, McDonalds for hamburgers, Nike for running shoes, etc. The breakthrough for nation-branding, however, came in the late 1980s and 1990s.

British politicians, in particular, in cooperation with communication and marketing experts, were early to use branding techniques in their efforts to remake the image of Britain. The Labour Party's success in the 1997 election was partly due to the use of such an approach. Tony Blair's New Labour corresponded to a large extent with a new image of Britain that not only gave voters new confidence (Leonard, 1997; Dinnie, 2016; Viktorin et al., 2018: 7-8). This also helped modernize the image of the UK in a way that, according to Dinnie (2016: 16), replaced 'Rule Britannia' with the media-made 'Cool Britannia' - the 'Old Britain' with a 'New Britain'. However, it was Margaret Thatcher that first introduced public diplomacy measures as a strategy of political communication in the UK. According to Cull (2013), this soon paved the way for using branding as a tool in promoting and communicating the nation. Later, Simon Anholt, an independent nation-branding consultant, came up with the idea of developing nation brands not only as a way of measuring the global reputations of nation-states but also to help countries improve their reputations by flashing specific favourable characteristics above others. In this way, corporate branding techniques were applied to countries, claims Mordhorst (2018: 245), who describes how such an approach was presented to governments and foreign ministries. Still, the Nation Brands Index launched by Anholt in 2005 as part of his own nation-branding consultancy was never able to provide evidence for any correlation between nation-branding campaigns and changes in a nation's image (Anholt, 2010: 2). The reason for this, of course, is that nation brands are complex constructions that cannot be propelled backwards or explained through reference to a specific programme or ambition of nation-branding. According to Keith Dinnie, a branding consultant who played a key role in the neoliberal globalization discourse around 2000, a nation brand is 'the unique, multidimensional blend of elements that provide the nation with culturally grounded differentiation and relevance for all of its target audiences' (Dinnie, 2016: 5; see also Mordhorst, 2018: 246). However, as branding consultants are hardly lords over nation brands, we as researchers need to do our part to keep nation-branding as a deliberate activity and the nation brand as the image or reputation of the nation separate. 


\section{Eirinn Larsen et al.}

The elements used to make nations recognizable on the global scene, however, are not always unique in themselves: it is the blend of the various ingredients that, according to the logic of the market, provides a nation with a competitive advantage through its ability to simply stand out. According to Svein Ivar Angell and Mads Mordhorst (2015), the Nordic countries have only to various degrees made use of professional branding consultants and programmes to improve their reputations as nations internationally. Angell and Mordhorst's research shows that the Danish government decided to make use of international branding gurus such as Simon Anholt, among others, after the cartoon crises of the early 2000s. In Norway, on the other hand, there has been no official branding programme, but policies were implemented around the same time to charter the country's international reputation (Angell and Mordhorst, 2015). Jezierska and Towns' chapter in this book goes further into the differences and similarities between the various branding programmes, policies and infrastructure of the Nordic countries. Suffice is to say that, today, in addition to their governmental and tourism websites, Iceland, Denmark, Finland and Sweden all have official country webpages and are more directly involved in programmes of nation-branding than Norway, which does not have an official country webpage (see Chapter 2 in this book for more on the online branding of the Nordic countries). Yet, despite these differences within the Nordic region, the logic and language of the market has contributed, albeit in different ways and to different degrees, to how the Nordic countries present their historical legacy as gender-equal nations - that is, as forerunners of gender equality.

\section{Different policy areas, competing Nordic images}

In this book, we have chosen to focus on how various policy fields enable, or drive, different and sometimes competing images and imaginings of the Nordics through the aid of gender equality and women's rights. To achieve this, we pay particular attention to foreign policy and diplomacy, peace and security, and legislative policies related to gender, rape, political rights and citizenship, as well as business and corporate boards, in addition to the international index industry. The various thematic approaches employed by the contributors include quantitative and qualitative methods, fieldwork and interviews, and historical, archival and literature studies. What are particularly valuable and innovative in our book are the ways in which processes of branding regions and nations are seen through gendered optics. Gender equality as branding has so far has gained little scholarly attention but much public and media interest. The book uses the concept of gender with care, not only analysing how notions of masculinity and femininity are coupled with, or decoupled from, the Nordic region or individual countries, but also pointing to contestations over the constructions of gender equality and 'Nordicity' historically, geographically, and in different policy fields and industries. 
The book consists of ten chapters and, as already noted, spans various disciplines and fields of research. Despite targeted attempts none of the chapters were written by Finnish or Danish contributors, though Finland and Denmark are included in analysis covered in various chapters of the book. In Chapter 1, Eirinn Larsen emphasizes the importance of history in Nordic gender branding. The strong and persistent external image of the Nordics as gender champions, she argues, has made history an increasingly important resource for individual Nordic countries seeking to distinguish themselves from other countries within the Nordic region and legitimate themselves as national promoters of gender equality in the world. However, the pasts being evoked when imagining the gender-equal Nordic nations differ considerably among the Nordic countries, although a particular structure is followed that aims to produce the impression that each country is best due to its seminal role in implementing modern standards of women's and gender rights. But, as Larsen asks, what was the importance of the role played by external actors in branding the Nordic countries as gender pioneers? She seeks to answer this question by tracing how the Nordic gender image or 'brand' first emerged around a 100 years ago within a context of rising nationalism and (trans)national women's suffragist activism. Her answer provides perspective and a background for the subsequent chapters, all of which are more contemporary in their focus.

Chapter 2, by Katarzyna Jezierska and Ann Towns, examines the different operational modes for nation-branding in contemporary Denmark, Sweden, Norway, Finland and Iceland, and how their respective uses of gender equality in their nation-branding efforts serve to position the countries quite differently. Through an examination of the official country websites that are set up to brand the individual Nordic nations, the chapter explores an important example of the deliberate branding in which the five Nordic countries are engaged. Through this material, Jezierska and Towns are able to identify differences and similarities between the five Nordic countries that provide an interesting backdrop for later chapters. They find that the degree to which and ways in which gender equality is highlighted differ quite drastically, with Sweden being the most assiduous user of gender equality for nation-branding purposes and Denmark the least, while Iceland, Finland and Norway lie somewhere in the middle of this spectrum.

Then follows Chapter 3 by Sigrun Marie Moss who discusses how gender equality has become part of diplomatic practice in the foreign services of the different Nordic countries, and how diplomats talk about the Nordic brand in relation to gender equality. When is the Nordic gender brand applied, and when is it avoided? Here, the Scandinavian diplomats interviewed express caution when talking about the Nordic brand, emphasizing that it can carry with it an air of moral superiority that can undermine the various ministries of foreign affairs' work on gender equality. Simultaneously, the strength of the Nordic region is emphasized, as the Nordic brand is also perceived as 
being useful when the countries come together to lobby or show in practice that women-friendly approaches can be economically viable.

Chapter 4, by May-Len Skilbrei, discusses how Sweden often presents itself, and is presented by others, as a role model in terms of gender equality. The steep increase in the number of rapes in the country that are reported to the police is therefore a concern: As Swedish NGOs and governmental institutions have invested considerably over several decades in promoting the idea that rape exists because of gender inequality, the seemingly high level of rape in Sweden makes it difficult to uphold a position as a gender-equality role model. In 2018, Sweden changed its legislation on rape to define the latter as non-voluntary sexual activity rather than coerced sex. The chapter explores how the revision of the rape law was debated and represented in the Swedish parliament and the media, with a particular focus on how the desired role as a norm entrepreneur was addressed.

Chapter 5, by Irma Erlingsdóttir, discusses how gender-equality images have been used in Icelandic national identity projections abroad. After an 'era of masculinities', which coincided with a neoliberal turn in the early 2000s, she shows that the 2008 financial crisis reopened a space for women in terms of political representation and participation, which led to a fundamental change in the gendered branding of Iceland internationally. This rebranding was largely made possible by feminist activists who put forward a societal critique that paved the way for the adoption of concrete genderequality policies as a crisis-response mechanism. Erlingsdóttir offers insights into the feminist struggles in Iceland, whose trajectories differ from those of the other Nordic countries, and shows how gender equality has, in the last decade, become a central part of Iceland's foreign policy.

In Chapter 6, Inger Skjelsbak and Torunn Tryggestad discuss what the promotion of gender equality entails for Norwegian peace mediation efforts, and what branding challenges and opportunities emerge from Norway's involvement in peace processes. In addition, the authors ask how the Norwegian engagement in such processes affects the gender branding of Norway as a peace nation. These questions are analysed in the light of the establishment and practice of the Nordic Women Mediators network and a set of Nordic national action plans to follow up on UN Security Council Resolution 1325 on Women, Peace and Security. The analysis concludes that Norway's ambitions in the area of peace and reconciliation take precedence over gender equality in the country's nation-branding efforts. In order to be an attractive peace facilitator in a competitive market, Norway must downplay its commitments to gender equality and leave the articulation of feminist foreign policy ambitions to the Swedes.

Chapter 7, by Stéphanie Ginalski, discusses the debate on gender quotas for businesses in Switzerland in the early 2000s, and how Nordic experiences with quotas were drawn on in public debates about the introduction of similar systems in Switzerland. Her findings indicate that the Nordic countries were important and useful points of reference in the parliamentary debates, 
although the imaging of the experiences of the Nordic region varied according to the speaker's position within the Swiss political landscape. The more to the political left, the more attractive were the Nordic countries as an example to emulate; the more to the right - that is, the more conservative the speaker was - the less attractive the experiences of these countries. Differences between the Nordic countries also affected which model Swiss parliamentarians chose to promote in the debate. While the left saw Norway as the most preferable of the Nordic countries, the right favoured the example of Sweden. The debates analysed by Ginalski thus provide an external view on the process of imagining and imaging the Nordic countries, which gives further insight into the contextual nature of the evaluation of the genderprogressiveness of the latter.

In Chapter 8, Cathrine Holst and Mari Teigen investigate how the national branding of Norway takes form through the voicing and silencing of various features of Norwegian gender-equality policies. Gender-equality policy is a hybrid policy field. In Norway, it consists of different areas, with equality legislation, the work-life balance, gender mainstreaming and gender balance in decision-making being the four most important. However, the focal point for Holst and Teigen's analysis is the Norwegian Ministry of Foreign Affairs' action plan on gender equality and selected speeches by the minister of foreign affairs and the minister of children and equality. These documents are core sites of communication about Norwegian gender-equality policies to foreign audiences, and the authors ask how their main messaging relates to existing knowledge about the features, merits and shortcomings of such policies.

Chapter 9, by Anne Hellum, focuses on the Convention on the Elimination of All Forms of Discrimination against Women (CEDAW) and its examination of the periodic state reports of four Nordic countries - Sweden, Denmark, Finland and Norway - with an in-depth look at Norway. With a focus on contestations regarding the relationship between CEDAW and these countries' gender-equality and anti-discrimination laws, Hellum's chapter discusses how the international equality and anti-discrimination standards that these countries support at the international level are resisted at the national level. A comparative study reveals that Norway to a much larger degree than the other three Nordic countries has modified its equality and anti-discrimination laws in response to the CEDAW Committee's criticisms. An examination of public debates in Norway regarding CEDAW's status in Norwegian law suggests that bringing the country's equality and anti-discrimination laws into line with the brand as a superpower on gender equality matters.

Chapter 10, by Tori Loven Kirkebø, Malcolm Langford and Haldor Byrkjeflot, asks how global indexes have helped build and shape the idea of Nordic gender exceptionalism. After tracing the rise of ranked indicators and the literature on their limitations and constructive power, the chapter examines 78 global and eight gender-specific indexes in which the Nordics perform 
strongly. It discusses which features of gender equality are (and are not) captured by the indicators and what the rankings communicate symbolically about the idea of and progress on gender equality. This is followed by an analysis of the presence of indicators in media discourse on the Nordics. Here, the authors make two principal arguments: that global indexes have powerfully and rather peculiarly shaped the discourse on Nordic gender exceptionalism, and that their constructive limitations and constituent power are often underplayed in policy discussions. Global gender rankings have, perhaps more than any other area, helped take the Nordics from 'middle way countries' of the Cold War to the 'top of the world' in the era of globalization.

Finally, the Foreword written by Cynthia Enloe frames the book by reflecting on what she sees as the central themes of the book and how they challenge us. The Afterword, written by Halvard Leira, sheds a more critical light on the book. He asks why, beyond profit or affection, states want to be seen and recognized, and through this pushes the reader to think beyond the insight presented in the various chapters.

With this book, we demonstrate that gender equality has become a highly strategic tool for the communication of the Nordic countries in an attempt to position themselves as 'best at being good'. We hope this insight will further discussions and research on the centrality of gender equality in the discourse of Nordic exceptionalism. Gender equality has become more than politics and experiences, it is a currency in a market place of values. Our book suggests that this currency should be handled with care.

\section{Notes}

1 During the 28th Session of the CEDAW, on 13-31 January 2003, the chairman noted that Norway was seen as a haven for gender equality and that the country's equality policy had provided positive examples for other countries; see https://www.un.org/press/en/2003/wom1377.doc.htm (accessible with a password only). The image of a 'gender superpower' was used by Norwegian Foreign Minister Børge Brende in 2016 to denote Norway to a Norwegian audience; see Vandapuye (2016).

2 See note 1.

\section{References}

Anderson B (1983) Imagined Communities: Reflections on the Origin and Spread of Nationalism. London: Verso.

Angell SI and Mordhorst M (2015) National reputation management and the competition state: The cases of Denmark and Norway. Journal of Cultural Economy 8(2): 184-201.

Anholt S (2010) Places: Identity, Image and Reputation. Basingstoke: Palgrave Macmillan.

Aronczyk M (2018) Nation branding: A twenty-first century tradition. In: Viktorin C, Guenow-Hecht JCE, Estner A and Will MK (eds) Nation Branding in Modern History. New York \& Oxford: Berghahn, 231-242. 
Browning CS (2007) Branding Nordicity: Models, identity and the decline of exceptionalism. Cooperation and Conflict 42(1): 27-51.

Clerc L and Glover N (2015) Representing the small states of Northern Europe: Between imagined and imaged communities. In: Clerc L, Glover N and Jordan P (eds) Histories of Public Diplomacy and Nation Branding in the Nordic and Baltic Countries: Representing the Periphery. Leiden: Brill-Nijhoff, 1-20.

Clerc L, Glover N and Jordan P (eds) (2015) Histories of Public Diplomacy and Nation Branding in the Nordic and Baltic Countries: Representing the Periphery. Leiden: Brill-Nijhoff.

Cull MJ (2013) The iron brand: Margaret Thatcher and public diplomacy. Place Branding and Public Diplomacy 9(2): 67-79.

Dinnie K (2016) Nation Branding: Concepts, Issues, Practice, 2nd edn. London: Routledge.

Einarsdóttir TJ (2020) All that glitters is not gold: Shrinking and bending gender equality in rankings and nation branding. NORA - Nordic Journal of Feminist and Gender Research 28(2): 140-152.

Elgström O and Delputte S (2016). An end to Nordic exceptionalism? Europeanisation and Nordic development policies. European Politics and Society 17(1): 28-41.

Jezierska K and Towns A (2018) Taming feminism? The place of gender equality in the 'Progressive Sweden' brand. Place Branding and Public Diplomacy 14(1): $55-63$.

Jónsson G (2014) Iceland and the Nordic model of consensus democracy. Scandinavian Journal of History 39(4): 510-528.

Langford M and Larsen E (2017) Branding as an analytical category. Paper presented at the Nordic Branding Concepts seminar, University of Oslo, 10 May.

Leer J (2016) The rise and fall of the New Nordic Cuisine. Journal of Aesthetics \& Culture, 8(1): 1-12.

Leonard M (1997) Britain: Renewing Our Identity. London: Demos.

Loftsdóttir K (2015) The exotic North: Gender, nation branding and postcolonialism in Iceland. NORA - Nordic Journal of Feminist and Gender Research 23(4): $246-260$.

Marklund C (2017) The Nordic model on the global market of ideas: The welfare state as Scandinavia's best brand. Geopolitics 22(3): 623-639.

Marklund C and Petersen K (2013) Return to sender: American images of the Nordic welfare state and Nordic welfare branding. European Journal of Scandinavian Studies 43(2): 245-257.

Mordhorst M (2018) The history of nation branding and nation branding as history. In: Viktorin C, Guenow-Hecht JCE, Estner A and Will MK (eds) Nation Branding in Modern History. New York \& Oxford: Berghahn, 243-254.

Ridderheim K (2014) Ny nordisk mat. En diskursanalyse om konstruktionen och reproduktionen av en nordisk matkulturell identitet. MA thesis, Uppsala University.

Scharff Smith P and Ugelvik T (2016) Embraced by the Welfare State? Scandinavian Penal History, Culture and Prison Practice. Basingstoke: Palgrave.

Skilbrei M-L and Holmström C (2013) Prostitution Policy in the Nordic Region: Ambiguous Sympathies. London: Ashgate.

Solum O (2016) Nordic noir. Populærkulturell suksess og velferdssamfunnets mørke bakside. In: Oxfeldt E (ed.) Skaninaviske fortellinger om skyld og privilegier $i$ en globaliseringstid. Oslo: Universitetsforlaget, 133-150.

Stougaard-Nielsen J (2016) Nordic noir in the UK: The allure of accessible difference. Journal of Aesthetics \& Culture 8(1): 1-11. 


\section{Eirinn Larsen et al.}

Towns A (2002) Paradoxes of (in)equality: Something is rotten in the gender equal state of Sweden. Cooperation and Conflict 37(2): 157-179.

Vandapuye HO (2016) Brende med ambisiøs likestillingsplan. Bistandsaktuelt, 4 June. Available at: www.bistandsaktuelt.no/nyheter/2016/handlingsplan-for-likestilling (accessed 15 January 2020).

Varga S (2013) The politics of nation branding: Collective identity and public sphere in the neoliberal state. Philosophy and Social Criticism 39(8): 825-845.

Viktorin C, Gienow-Hecht JCE, Estner A and Will MK (eds) (2018) Nation Branding in Modern History. New York \& Oxford: Berghahn.

Vuignier R (2016) Place marketing and place branding: A systematic (and tentatively exhaustive) literature review. Working paper de l'IDHEAP (5). Lausanne: University of Lausanne. 


\title{
1 'The gender-progressive Nordics'
}

\section{A matter of history}

\author{
Eirinn Larsen
}

The Nordic countries have worked together for over four decades to improve gender equality in all aspects of society. Gender equality between the sexes is a condition for the success of the Nordic Model and a pillar of the modern Nordic welfare states.

(Nordic Co-operation, n.d.)

History is an important resource in the current attempt to brand the Nordics as pioneers of gender equality. The Nordic Council of Ministers, for instance, explains the success of the 'Nordic Model' and the 'Nordic welfare states' as the result of enduring Nordic collaboration on gender equality over decades. Yet evoking history to make the region shine in this way, as champions of gender equality and progressive social models, is not simply a reflection of historical developments but also involves contemporary constructions of the past. In fact, the geographical area known as Norden has no common historical meaning to those who inhabit it today. Since the nineteenth century, five distinct nations have belonged to the Nordic area. Each has its own national language, culture and historical identity, its own set of myths and heroes, stars of independence and national events to commemorate. Surely this makes it difficult to claim pan-Nordic ownership of a value such as gender equality in the way that the Nordic Council of Ministers does, on this occasion to enhance the reputation of the region as a knowledge hub.

Besides, for individual Nordic countries, the historical experience of being Nordic is not necessarily a unified memory. ${ }^{1}$ Until the mid-twentieth century, the Nordics were more rivals than friends. While Sweden and Denmark were the monarchs, Finland, Norway and Iceland were the underdogs. This historical asymmetry also affects how history is used today to brand the Nordic nations as gender-equal. Rather than showcasing the historical legacy of the region as women-friendly, Nordic countries flash their own individual historical breakthroughs as gender-progressive states and societies. A very telling example in this respect is Finland, which, according to the governmental webpage, is a pioneer of gender equality on account of its

DOI: $10.4324 / 9781003017134-1$ 
early enfranchisement of women (Ministry of Social Affairs and Health, Finland, n.d. a). Under the headline 'Finland Is a Gender Pioneer', it is declared that 'Finland is one of the world's leading countries in fostering gender equality. It was the first county to grant women full political rights' (Ministry of Social Affairs and Health, Finland, n.d. b). Yet Finland's decision to flaunt its early enfranchisement of women is far from coincidental. Women's right to vote has been a standard of appropriate behaviour among states, and thus a symbol for the fulfilment of democratic rights in general, since the end of World War I (Towns, 2010: 119-120). This means that the nation-branding of individual Nordic states is not just situated within a historical context in which certain laws and reforms were made to better the gender rights of women and men. The national imagining of individual Nordic countries as gender pioneers is also done by evoking a past that aims to favour them globally in the present. Thus, the key question is what historical times and roles individual Nordic countries currently construct for themselves when branding themselves as gender-equal nations. And, how do the current historical imaginings of the 'gender-pioneering Nordic nations' relate to the foreign images made of the Nordic region - and individual Nordic countries - a hundred years ago? The Nordic gender image is not entirely new, yet it remains somehow unclear how it developed and what role external actors played in the process.

To answer these questions, I draw upon literature that understands history and the use of history as a contemporary process of commemoration and nation-building. Pierre Nora, for example, speaks of lieux de mémoirethat is, sites of commemoration - and argues that this process makes history stand still in accordance with the political aims and needs (of the nation) of the present (Nora and Kritzman, 1996). In this chapter, I investigate the gender progressiveness of the Nordic countries both as a contemporary historical imagining of the Nordic nations and as a foreign image first made when women's demands for political rights intensified at the turn of the nineteenth century (Clerc and Glover, 2015: 6). The sources used are predominantly official and governmental webpages from the five major Nordic countries. In addition, historical sources and material from the international suffrage movement, represented by the International Council of Women (ICW), the International Woman Suffrage Alliance (IWSA) and the Norwegian National Suffrage Association (NNSA), have been consulted.

\section{Best at being first!}

The consistent external representation of the Nordics as gender-equal is key to understanding why individual Nordic countries now turn to history in their gender-branding discourse. We know that international interest in the small Nordic countries intensifies when the annual global indexes on gender equality are released - most often with similar results: The Nordics take it all, year after year, when it comes to gender equality. So, what can be learned 
from them, the American weekly Forbes asked in 2018 as journalist Shelley Zalis (2018) wrote up 'Lessons from the World's Most Gender-Equal Countries'. Evidently, this strong and stable external image of the Nordic region makes it more than a challenge for its five different states to be recognized as individual stakeholders of gender equality. This has made history an important source of differentiation, a key element in all forms of branding.

Although the historical imagining of the gender-progressive Nordics has a foot in the real, it is predominantly a contemporary construct made to distinguish the individual Nordic state from other states. Wordings of differentiation are therefore frequently used when the Nordic countries present themselves to foreign audiences as gender pioneers today. This most often takes the form of self-assertive comparative statements, wherein the world or other continents hold the role of the laggard. Such statements follow a specific pattern that provides the imaginary of a historical frontrunner of gender rights: for example, ' $\mathrm{X}$ was the first in the world to do $\mathrm{Y}$ ', ' $\mathrm{X}$ are or were the first to $\mathrm{Y}$ ', or, more modestly, 'X did $\mathrm{Y}$ in time'. The webpage Guide to Iceland, for instance, presents Iceland as 'the first country in the world to grant equal inheritance rights to both men and women [in 1856]', as well as the country that 'had the world's first democratically elected head of state' (Chapman, n.d.). On the country's official webpage, the message is similar, although the role of Iceland as a historical gender pioneer is not linked to women's rights but to men's rights as fathers. It states: 'Iceland celebrated the millennium by introducing the first exclusive paternity leave in the world' (Iceland.is, n.d.). Yet, on the official governmental page, none of these examples are mentioned. Here, the image cherished is simply that Iceland remains at the top of most global rankings of gender equality. For instance, on 18 December 2019, the story created and published by the Prime Minister's Office was 'Iceland Remains the Top Country on the World Economic Forum's Gender Gap Index' (Government of Iceland, 2019).

The second way in which history is used to enhance the credibility of the Nordics as nations with a long tradition of gender equality is by providing explanations as to why they became so gender-equal in the first place. Such use seeks to connect the countries' historical gender progressiveness to their societal, geographical, commercial or even climatic qualities. For instance, the site Guide to Iceland turns to Iceland's role as a seafaring nation to explain why women in old Iceland had the reputation of being strong and independent, a notion that is also supported by two of the Icelandic sagas. It elaborates:

women in Norse society could be granted a greater level of respect and freedom than their European counterparts. Women managed the finances of the household, ran the farmstead in their husband's absence and could become wealthy landowners in widowhood. They were also protected by law from unwanted attention or violence.

(Chapman, n.d.) 
However, larger historical explanations of why the Nordic countries are gender-equal do not fit well within the tight format of nation-branding. The language of branding is more about declaring and exemplifying a product's qualities, not explaining why it possesses them. Accordingly, few of the Nordic states turn to history to explain the current situation in the way Iceland can be seen to do above. Denmark's official webpage provides a good illustration. This page simply affirms that Denmark is a gender pioneer by stating that such a role is old news to them: 'Women's influence in Danish politics is nothing new. In 1924, Nina Bang became the world's first female minister in a country with parliamentary democracy' (Denmark.dk, n.d.).

The third use of history on Nordic country webpages addressing gender equality relates to the imagining of time and progress itself. Whereas genderequality discourses formerly focused mostly on women and sometimes men, this is no longer the case. Today, gender has become something far more diverse and fluid than it was previously. Consequently, measuring gender equality means taking into account a range of different issues, such as the rights of fathers and previously marginalized sexual groups, most often referred to under the umbrella term 'LGBTQ'. Historical landmarks are mentioned, however. For example, on the Norwegian governmental webpage, for instance, it is stated that in Norway a 'Common Marriage Act entered into force on 1 January 2009. This Act gives all lesbian and gay persons the right to enter into marriage irrespective of sexual orientation' (Government. no, 2019). In this way, the achievement of gender equality is not presented as a linear development, running from zero to advanced according to one dimension only, but a multi-dimensional undertaking. This supports the image that Norway, in this case, remains on top of all things related to gender.

The gender binary man-woman still dominates in Nordic gender-branding discourse. This is an aspect that will be elaborated on further in several chapters of this book, including in relation to the disparity between Nordic images made for foreign audiences and those produced for domestic political purposes (Danielsen and Larsen, 2015). Regardless of this, a very striking feature of the ways in which history helps to brand the Nordic states as gender-equal, however, is the degree of conformity seen in this area. All five Nordic countries highlight their historical legacy as gender-equal nations by flashing that they were the first to commit to the new political value of gender equality in areas that range from politics and welfare to equalized economic rights for women and civil rights for gays and lesbians, etc. As a result, the main slogan within Nordic gender-branding discourse would appear to be that the Nordics are best at gender equality because they were the first to adopt current standards of gender equality. To maintain this image, however, the Nordic countries have had to mobilize or evoke remarkably different pasts.

\section{Different pasts evoked}

History helps countries to distinguish themselves from others, at the same time as its use for purposes such as nation-branding closely relates to the 
nation as an imagined community. This means that the pasts adduced when the Nordic countries communicate their gender-friendliness are never random but are instead used in various processes of nation-building and nation-branding. We have already mentioned Finland, which on its governmental webpage brands itself as the first country in the world to introduce equal political rights for men and women. This historical imagining of the Finnish nation-state is related to a 1906 amendment that was made possible because Russia, to whose empire Finland then belonged, was going through a time of revolution. Finland's role or self-imagining as a pioneer of female suffrage is thus closely related to the Finnish struggle for national independence from Russian control: universal suffrage was introduced in the same year that the country gained home rule. Yet the current use of history does not stop there. On the same webpage, Finland is presented as a country in which the struggle for gender equality began even prior to the birth of the new Finnish nation-state. The webpage states: 'A move towards the equality of women and men was taken in Finland long before the country became independent. In the 1850s, Finnish women activists read John Stuart Mill and spoke about the importance of education for girls' (Ministry of Social Affairs and Health, Finland, n.d. b). This historical representation of Finland is interesting for several reasons. First, it illustrates that the struggles for national independence and women's rights coincided in Finland (Hagemann, 2009; Blom, 2012: 611; Sulkunen, 2015: 94-96). The emancipation of women thus became a more integrated part of the Finnish national memory simply because it overlapped with the country's liberation from Russian power. Second, the image produced of Finland as an early mover on women's issues overrules the historical facts referred to in the actual branding text. One major anachronism is that Mill's book The Subjection of Women was first published in 1869, not in the 1850s. Of course, Mill published his On Liberty in 1854, which later was referred to both by supporters and opponents of women's liberation. However, this book did not explicitly address the issue of women's liberation in the way that his later book did, which sparked the first explosion of the women's movement in many countries. Hence, to argue that Finnish women were reading Mill and discussing the importance of educating girls in the 1850 s is probably not historically correct. In nation-branding discourses, however, the specific serves the general, not the other way around, and the historically accurate gives way to how the nation is being imagined now. In fact, it is the delicate combination of being sufficiently specific to be trustworthy and general enough to get the quality of the nation across that characterizes the use of history in Nordic gender-branding discourses.

The Norwegian example is illuminating in this respect. According to the webpage of the Norwegian government, Norway's pioneering role as a gender-equal country can be communicated simply by declaration. The webpage states: 'Norway has a long tradition of working for women's rights and gender equality' (Government.no, 2020a). What this tradition consists of, however, is more unclear. Notably, when former Norwegian foreign 
minister Børge Brende launched an international plan for women's rights in front of a national audience in 2016, he also justified this without explaining how Norway had become a historical pioneer of gender equality. Brende simply stated that 'Norway is a forerunner of gender equality and this legitimacy gives us the opportunity to take a lead, globally.... Norway is a gender superpower' (Vandapuye, 2016: 2). However, in contrast to Iceland or Finland, when emphasizing the nation's historical landmarks in terms of gender equality, Norway is predominantly branding its role in the international arena. The Norwegian webpage tailored for foreign readers, for instance, focuses predominantly on the country's commitment to international laws and standards concerning women's rights and gender equality. According to these representations, Norway is a pioneer in the ratification of international anti-discrimination conventions. The country's legitimacy as a pioneer of gender equality is thus built on its own historical legacy and imagining as an internationally oriented (peace) nation:

The UN Convention on the Elimination of All Forms of Discrimination against Women (CEDAW) was adopted by the UN General Assembly on 18 December 1979, entered into force on 3 September 1981 and has been ratified by 189 states. Norway ratified the convention on 21 May 1981.

(Government.no, 2020b)

The impression created in the above quotation from the official webpage of the Norwegian government, which has been a conservative coalition government since 2013, is that Norway has always taken its international humanitarian obligations seriously and continues to do so today. However, as a rule, the historical period in focus when Norway presents itself to the world as a gender-equal nation is the post-1970s. This differentiates Norway from Finland, as well as from Iceland and Demark, which are all more backward-looking. Or, put the other way around, within the international arena Norway brands itself as an experienced and reliable international partner. Still, what is striking about the way in which Norway represents itself to the world is its apparent reluctance to mention the fact that the country was the first to ratify this particular international convention. Norway's use of history is thus more discreet and subtle than that of the other Nordic states. The national imagining is that to be first simply comes naturally for Norway. Such an approach stands in contrast to the role of history in the official Swedish gender-branding discourse, to which I now turn.

Sweden has long pursued a women-friendly policy, although none of the relevant historical milestones are included in the government's presentation of the country on its webpages today. Instead, the picture painted by the centre-left coalition government of 2020 is that Sweden has taken the feminist issue to another level through the 2014 launch of what had never been seen before: a feminist government with a specific feminist foreign policy. 
On the governmental webpage, it is stated that 'Sweden has the first feminist government.... A feminist government ensures that a gender equality perspective is brought into policy-making on a broad front, both nationally and internationally' (Government Offices of Sweden, n.d.). Sweden is thus imagined as a country that continues to be a gender pioneer. In other words, it does not rely on history but makes it continuously in new ways. Instead of showcasing its past achievements, the Swedish government flashes its contemporary innovation regarding feminist politics.

This identity as 'progressive now' fits extremely well the role and function of Sweden as a utopia in foreign political discourses (Andersson and Hilson, 2009: 220). As Jenny Andersson and others have argued, the Swedish self-imaging as avant-garde relates to the rise of foreign perceptions of Sweden from the interwar period onwards, particularly in the USA, which later were appropriated by the Swedish authorities (Andersson and Hilson, 2009; Marklund, 2009, 2017). Within the frame of this imaginary, Sweden was an advocate of progressive values and social rights in general, and its population was held as being the most modern of all people. As a result, when branding itself as a pioneer of gender equality, Sweden is capitalizing on political and cultural images of the country that are well established both globally and domestically. Strikingly, this makes Sweden less concerned about the past when imagining itself as a gender pioneer, whereas the other Nordic countries all itemize their progress in this area, legitimizing their claims through reference to a handful of national advancements and reforms.

Clearly, this picture of Sweden as the most progressive and pioneering of all countries also needs to be seen in relation to the country's historical status and identity as a Nordic superpower within the Nordic region. In the 1600s, the country was one of Europe's most powerful military states. And during the Napoleonic Wars, Sweden was on the winning team against France that forced the Danish king to cede Norway to the Swedish king in 1814 as part of the war settlement. Swedish national identity thus seems less bound to the national awakening of the nineteenth century, at least in comparison with its neighbours to the east and west. The situation with Finland, Norway and Iceland, however, is different. At the turn of the last century, they were all claiming independence from foreign rule and began constructing histories of their own, which helped them to define themselves in opposition to their neighbouring oppressors, that is, Russia, Sweden and Denmark. Norway, gaining home rule in 1814 after 400 years under Danish rule, was until 1905 in a personal union with Sweden. Finland, on the other hand, had home rule from 1906 but remained a grand duchy in the Russian Empire until late 1917. Iceland, declared a sovereign state in 1918, was for its part in a personal union with the Danish crown until 1944. History served as a major justification and raison d'etre et faire of the nation in all these processes of nation-building. In the early 1900s, this also helped the Nordic gender image to develop within the confines of the international suffragist 
movement, an image that depicted them as frontrunners in the campaign for women's political rights. Within the frame of this imaginary, however, Sweden, the old monarch of Scandinavia, and Denmark, the second best, held no prominent roles.

\section{The history of the Nordic gender image}

Until female enfranchisement became the new normal of international society by the end of World War I, the old and so-called civilized nations were characterized by keeping women out of politics (Paxton et al., 2006; Towns, 2009). Only barbaric countries allowed women to rule, the argument went, which made the nineteenth-century state in most countries a true gentlemen's club (Towns, 2014; Florin, 2018: 29). However, this situation began to change around 1900 as a growing number of countries met women's demands for political citizenship, though a common characteristic of the first frontrunners of the female vote was that they all belonged to the growing class of newborn nation-states as opposed to the great powers represented by Great Britain, France and Germany. These latter were the leading countries of the world until the USA announced its interest in joining their ranks towards the end of the nineteenth century. With this, women's issues also entered the international scene, but not necessarily because the federal American state pushed the female issue in the same way that the country's women did. The first to make women political subjects were nations belonging to the periphery of civilization, including the countries of the Nordic regionor Scandinavia, as it was generally referred to at the time. ${ }^{2}$

Before the outbreak of World War I, New Zealand (1893), Australia (1902), Finland (1906) and Norway (1907/1913) all granted women the right to vote. ${ }^{3}$ For all but New Zealand, suffrage also meant the right to stand for election and represent the state. Evidently, this enabled the aspiring nation-states mentioned above to symbolize new sets of values on the international scene, including cultural and moral values stemming from their ability to take the female question seriously. For some countries, the female vote thus became a strategizing matter of relevance to more than domestic and party politics. Feminist claims were also included in diplomatic manoeuvring and the rising global competition for 'modernity prestige'. In Werron's (2014: 71) words, this was because new forms of public communication helped in the creation of universalized 'third parties'. Consisting of international organizations and journalists, among others, and creating new and imagined global audiences, these parties were to challenge the hegemonic status of the old monarchs of international society. As a result, the idea of women's suffrage as a sign of the progressive, civilized nation began to circulate more freely and help distinguishing states accordingly.

In June 1890, Norwegian politician John Teodor Lund from the Liberal Party argued in the Norwegian parliament that Norway could 'increase its international reputation and place in the civilized world by introducing 
the female vote' (Kolstad, 1963: 35). At the time, Norway was characterized by rising nationalism and independence fever. Since 1814, the country had shared its king, foreign policy and diplomatic service with the Swedes. Lund's statement is thus an indication that the political opposition was advocating for a more independent role for Norway within the SwedishNorwegian union. Interestingly, the term likestilling, which in modern Norwegian usage is strongly associated with gender equality, was in 1886 used to call for full equality between Norway and its union partner, Sweden (Danielsen et al., 2015: 13). While the demand, which was mostly about numbers of representatives in the ministry council of Sweden-Norway, responsible for foreign affairs, was not followed up, Lund's proposal appears to have been a strategy to enable Norway to be regarded as a de facto state with its own foreign policy - or, more precisely, a consular service to take care of the country's economic interests. Interestingly, this suggestion, to make the female vote a foreign policy tool, was made more than a decade before historian and peace activist Halvdan Koht would argue, in 1902, that Norway should commit to the development of international law and peace as an independent nation-state. In the words of Halvard Leira (2015: 22), an international relations scholar who specializes in Norway's role and identity as a 'peace nation', smallness was from early on seen as 'necessitating a focus on acting in a way that could enhance [Norway's] status'.

By the early 1900s, the female vote went from being a sign of uncivilized nations to a positive feature of the modern and progressive state. This transformation was partly the work of a rising international society of feminist organizations, but it was also closely related to small and geographically peripheral nations' drive for status and independence (Oldfield, 1992: 215; McDonald, 2009: 25-31; Towns, 2009, 2010). Women, the argument went, were as important as men for the well-being of the national home. Nordic suffragists also adopted or contributed to this discourse of nationalism (Blom, 2012). At the 1911 international suffrage conference in Stockholm, Swedish writer Selma Lagerlöf (1911) argued in her speech 'Home and State' that women had done their lot for life and civilization, as well as for 'the good of the race', by creating homes and bringing human beings into the world. Consequently, they deserved the vote as much as men, since no state could exist without the traces that women had left on earth. Above all, however, the feminist nationalist discourse was a question of strategy. In the early 1900 s, there was a rising need to fight down anti-suffragist sentiments and to make male parliamentarians see that it would be to the nation's advantage to take women on board. In the Nordic region, Finland was first out, in a process that, according to Irma Sulkunen (2009: 84), went 'surprisingly rapidly and almost unnoticed'. During the revolutionary fervour of 1906, the Russian tsar granted a number of Finnish political demands that included calls for the female vote and eligibility for parliament. Since 1892, universal suffrage had been a major issue for the Finnish Women's Rights Federation. And seven years later, in 1899, the Finnish Labour Party decided to 
advocate for equal suffrage for men and women, which in hindsight has lent credibility to the country's claims today to be a gender-equality pioneer (Ministry of Social Affairs and Health, Finland, n.d. a). However, when the international suffragists began organizing to give force to their demands for equal political rights for women, it was Norway, not Finland, that drew the longest straw. As we will see below, racial discourses prevalent at the time were an important element in, if not a prerequisite for, the development of a Nordic gender image by an American-dominated international suffrage movement.

\section{Looking for new success stories}

For a long time, American suffragists had advocated for the need to include women in parliament by providing women with equal political rights. To achieve this goal, Elisabeth Cady Stanton and Susan B. Anthony, two of the most influential nineteenth-century feminists and initially members of the abolition movement, had begun to play on anti-abolition sentiments and ethnic and racialized stereotypes (Dubois, 1997: 179; Finnegan, 1999: 5). Truly, the worst case for many American feminists, originating in the white, Anglo-Saxon and protestant middle-class, was to see the free AfricanAmerican man enter parliament before themselves. During the progressive era, these WASP women organized and campaigned for social reform within most social fields, from temperance and peace to welfare, civil and political rights. Still, American women lacked suffrage. Thus, in 1888 the International Council of Women (ICW) was launched as a new avenue in which WASP women might seek to advance and enhance their reputation in the eyes of men in power. However, as the German secretary Alice Salomon later described it, it was an organization built on air, as at that point in time there were no national councils that might join it (Rupp, 1997: 15).

At first, the International Council of Women was nothing more than a North American organization, with limited foundation and support beyond the USA. The women of the Nordic region were all slow to set up national councils. Sweden and Denmark did so in 1898 and 1899, respectively. Norway followed in 1904, a year before its union with Sweden was dissolved. Upon the dissolution of the union, the leader of the Norwegian National Council of Women, Gina Krog, made a small handout on Norwegian history and politics for circulation. Addressed to the ICW, the publication contained various facts to help members to differentiate between the two former partners of the Swedish-Norwegian union. Strikingly, the handout, which was written in English, put Norway in a positive light by representing Sweden as the conservative and anti-progressive 'other' to the new nation-state Norway: 'In Norway there is a democracy (only half-realized, however, as women had not yet obtained political suffrage) and a thorough parliamentary system. Sweden is far more politically conservative, and her suffrage is still very limited' (Norwegian National Council of Women, 1905: 16). 
In 1911, Finland and Iceland were the last of the Nordic countries to join the growing international family of women's councils (Rupp, 1997: 16). Yet, even before then, the ICW had already faced problems. The national auxiliaries of the organization were for a long time few and weak. More importantly, the ICW's members soon stopped agreeing on its over-reaching cause - that is, female enfranchisement. With the inclusion of anti-suffragist women at the London conference in 1899, the ICW was no longer really a suffragist organization. To fill the gap created by this development, two radical-minded Germans initiated an alternative meeting. The idea of forming an independent international organization, however, came from Carrie Chapman Catt, a rising star within the American suffragist movement. In 1900, Chapman Catt succeeded Cady Stanton as president of the National American Woman Suffrage Association (NAWSA), and for 28 years, from 1904 to 1932, she was the front figure of the International Woman Suffrage Alliance (IWSA), which had female suffrage as its ultimate goal (Somervill, 2003: 60-61).

For the emerging discourse on the gender-progressive Nordics, this strategic and generational shift within the organized international feminist movement would prove decisive. Although the Nordic countries never became a model for other states to follow, new images of them soon began to spread. Sissel Rosland (2017: 201) has argued that to understand the significance of foreign examples within the feminist movement at the time, 'it is necessary to consider the hegemonic frames the campaigners were challenging'. Those opposing the female vote were well organized. They arranged meetings, wrote petitions and took to the streets to advocate against giving women the vote. In this context, the experiences of those countries that in fact were making progress were very valuable for those campaigning for women's enfranchisement. Accordingly, the IWSA began to tell the world that the Nordic region contained the most gender-progressive countries in the world. Or, in Chapman Catt's words, extracted from a speech at the 1908 international suffrage conference in Amsterdam: 'in actual gains the Scandinavians are in the lead. All honor to that noble race! Once it was the pioneer upon the great unknown waters of the world; now it is the leader upon the high seas of human progress' (IWSA, 1908).

That the president of the IWSA would in 1908 portray the Nordic countries as the world's pioneers in the field of gender equality, however, was not something that could be taken for granted at the time. Also on the other side of the world, down under, progress was being made. However, the physical appearance of the Nordic people was well fitted for the racialized hierarchies the international societies and suffrage communities were producing. According to Towns (2010: 92), Chapman Catt promoted the view that women were not only more civilized than men but also more civilized than 'uncivilized' women of 'lesser races'. This rhetoric also mirrored the actual power relations within the international suffragist movement led by Northern Americans and Europeans. For delegates from Southern 
Europe, this would lead to frustration. The French suffragists who had at first hoped to maintain a symbolic lead within the international movement were soon to understand that the axis of the organizational monument was shifting. Karen Offen (2000: 154) writes that the torch was carried by the Anglo-American world, and that protestant representatives also took the lead on moral issues. For the leadership and discourse of the international suffragist movement, it was the Nordics that became the tool for forging a specific subject position as civilized women. At the 1909 IWSA conference in London, an Italian representative would describe the event as uniting the Anglo-Saxon race (Vangen, 2020). Later, French Germaine Malterre-Sellier would describe the IWSA's offices as a place where 'very often the Latin and oriental elements felt isolated and estranged... where a spirit predominates that I will call Nordic, for lack of another name' (Rupp, 1997: 70).

Not only was the IWSA created and run by American suffragists, but it also developed out from American needs. Additionally, it initially trumpeted the idea that the USA was the most advanced country in terms of women's rights. At its very first convention in 1902, held in Washington, DC, where all the participants were invited to the White House to meet US President Theodore Roosevelt, the divide between the Old and the New Worlds was presented as a gain for American women especially. In her address to the participants, Chapman Catt declared:

It is well known that the new countries are far more free from the mandates of custom and conventionality than the old ones; and that dissenters from established usage are far more willing to adopt new ideas and extend liberties, than those bound by traditionary beliefs.... That liberty has continued to grow until unquestionably American women are less bound by legal and social restrictions than the women of any other country, unless we except progressive Australia and New Zealand.

(IWSA, 1902: 39)

As the above quote shows, the USA was initially imagined as the frontrunner of the international suffragist movement. The new countries 'down under' were also advancing but, as indicated by the speech of Chapman Catt, who in 1904 succeeded Susan B. Anthony as president of the IWSA, New Zealand and Australia were in their eyes never worthy of the status of pioneers of women's rights. Such a view corresponded well with how things were seen also in the Nordic countries. From the formation of the first national women's rights associations in the 1880s, American women had represented an example for Nordic feminists. Gina Krog, the Norwegian suffragist and leader of the Norwegian National Women's Council, wrote in her telegram to the 1902 suffragist convention in Washington that

no other country in the world has received the inspiration in our work which we have received from the Unites States; to no women in the 
world are we so indebted as to the women of your country - those great and noble pioneers.

(Krog, 1902; see also Vangen, 2020: 43)

But, with the gradual advancement of women in the Nordic countries in terms of suffrage, little by little the picture of the USA as the symbolic leader of the suffragist cause began to change.

\section{Challenging the USA as symbolic leader}

In 1901, Norwegian women received the right to vote in local elections, which the country's suffragists had campaigned for, among other things, by making reference to the American states as frontrunners. The vote was not fully won, however: the requirements were linked to economic capacity and age. However, despite these rules, which favoured women of the bourgeoisie, 100 women were elected to seats in local governments from 1901 (Larsen and Øksendal, 2013). In 1906, similar developments took place in Finland, as we know, but at the national level, which soon became front-page news in the Nordic countries and possibly beyond. The Norwegian newspaper Aftenposten could at least inform its readers on 15 June 1906 that 19 of the new representatives of the Finnish national parliament were women, a fact that was illustrated by a picture showing 13 of them (Larsen, 2013: 196). Contrary to what Sulkunen has suggested, then, the event did not pass unnoticed in other countries. Within the international suffrage movement, the Finnish victory, as it was presented, would also change the discourse on the Nordics in ways that would have an impact well beyond the movement itself.

When the IWSA was formally launched, in 1904, during the second conference held in Berlin, it managed to attract media attention. Newspapers were increasingly interested in covering the well-off and sometimes quite eccentric suffragettes and their fight for political enfranchisement. The conference, which was closely prepared by Chapman Catt and her board, was covered by several newspapers and was clearly popular with journalists and readers. The organization had also developed a media strategy: All national delegates had to prepare their addresses carefully beforehand and to arrive at the conference with multiple printed copies of their speeches in their handbags. Free copies could in this way easily be distributed to journalists and members of the audience, and the movement gained what it had worked for-increased public attention and support for its cause. At this stage, however, only Denmark and Sweden were formal members of the IWSA, although Norway would join two years later for the upcoming conference in Copenhagen. It took a further two years for Finland to join, and Iceland until 1911. Yet, compared to the previous conferences, the event in the Danish capital was a mammoth undertaking. The numbers of participants grew, as did the rules, and three different languages were used simultaneously, which says a lot about the social background of the women involved. The choice 
of location for IWSA conferences was always strategic, the idea being that the conferences would increase public interest in and support for the female vote in the countries in which they were held. The president of the Danish Women’s Suffrage Society, Marie Sørine Louise Nørlund, wrote in 1906 in Jus Suffragii, the international magazine of the IWSA, that the 1906 conference in Copenhagen had been of great benefit for the suffragists' work in Denmark. Clearly, it had contributed to a change in public opinion, which 'now is on our side' (Jus Suffragii, 1906: 7). However, when Finland took the first step in the Nordic region to enfranchise women at the national level, this attracted the president's attention. In Carrie Chapman Catt's words, however, the Finnish victory had come as a total surprise:

Yet suddenly, almost without warning, we see upon a summit another army. How come it there? It has neither descended from heaven, not climbed the long hard journey. Yet there above us, all the women of Finland stand today. Each wears the royal crown of the sovereignty of the self-governing citizen. Two years ago, these women would not be permitted by the law to organize a woman suffrage association. A year later, they did organize a woman suffrage committee, and before it is yet a year old, its work is done.

(Luno, 1906: 49)

Clearly downplaying the victory and effort of the Finnish women, Chapman Catt continued her narrative by presenting American women as the symbolic and practical leaders of the international suffrage movement. Finnish women, it seems, were not as qualified to be an example for others as the women of the USA, New Zealand and Australia. It was the opponents of female enfranchisement, she continued, who so persistently had refused to accept these gains of the female vote and see them as important:

They declared these States and Nations had no history and gave no assurance of a stable future; they said they were too new, their population too small, their people too impulsive and irresponsible for their acts to be taken seriously.

(Luno, 1906: 50).

This indicates that the fact that a country lacked an established history or a long stable past as a nation and state was a common argument among anti-suffragists for not taking feminist victories in new countries seriously, a point that would be taken on board by the IWSA in its propagandist discourse. In addition, the president argued that in order to be worthy of the role of inspiring others, a state had to be sovereign, or at least be in a stable environment that ensured that any success stories would continue to be successes. The fear was that feminist victories might be belittled by their opponents and that this would damage the entire suffragist movement. Her 
choice of country to inspire suffragettes fell on Norway, a country that few in fact knew much about.

\section{Trusting Norway over revolutionary Finland}

By the time the IWSA organized its fourth reunion in 1908, Norway had introduced census-based national suffrage. Strikingly, the significance of this change to Norwegian law, whose terms were far less generous than the bill already passed in Finland, was emphasized in Jus Suffragii. The front cover of its July 1907 edition declared 'HURRAY FOR NORWAY!!!!' And when the national representatives met in Amsterdam the following year, it was Norway - and not Finland - that was presented as the country to look to for inspiration. The reason for this, the president declared, was that 'the Norwegian Act lent a new dignity and significance to all the victories which had preceded'. It was not just that Norway had granted 'full suffrage rights and eligibility to women upon exceedingly generous terms'. In terms of 'the attitude of nations towards our cause', the act of the Norwegian parliament meant far more than an isolated victory, declared Chapman Catt in her general address in Amsterdam on 15 June 1908. The strategic importance of the Norwegian victory was thus made out to be far larger than that of Finland. Again, the decisive element was the hegemonic status of the antisuffragists. The tendency to ridicule the progress of the suffragists' cause, by belittling any achievements and minimizing the movement's influence, was widespread. It was therefore important to go for the safe option, the example that would not be ruined by the anti-suffragists.

'It is true', they say 'Finland is old enough and has creditable history, but its people are in a state of revolution; what the Czar has given, he might take away. We shall wait'. It was at this point in the world's controversy that the Norwegian victory came. Norway was a country with an honorable history, a stable and independent government. It was evident that the enfranchisement of women had been accomplished after calm deliberation, by a people acknowledge to intelligent, honest and conscientious. For the first time the opponents were compelled to admit that a genuine victory for women suffrage had scored.

(Luno, 1906: 50)

The president of the IWSA was quick to construct new and more favourable images of the Nordic region as the Nordic countries increasingly met women's demands for political citizenship. But it seems that she also knew how to differentiate between them in order to achieve the overall goal of her movement. The method used followed the terms set in the nationalist discourse at the time, according to which a country without a past and a well-defined history did not merit significant attention. Both Finland and Norway fulfilled the required criteria according to the American suffragist, who played 
loosely with the facts to present them as old and noble, when in fact the old monarchies of the Nordic region were Sweden and Denmark. Furthermore, the latter countries were also on the way to allowing women to vote: 'Both countries are intelligent and progressive', which enabled Chapman Catt to feel confident that the way in which the question of women's suffrage was to be solved in the two countries would provide important lessons for those working for this cause throughout the world. Still, the Norwegian victory hung the highest: 'I venture the prediction, that, when the final chapter of the history of suffrage shall be written, it will record that the enfranchisement of the Norwegian women marked a turning point in the struggle' (Luno, 1906: 49-50).

The private correspondence of Fredrikke Marie Qvam, for years the leading figure in the Norwegian National Woman Suffragist Association, further illustrates how Chapman Catt made Norway - and not Finland the symbolic frontrunner for the international suffragist movement. During the planning for the 1908 conference, the president wrote multiple times to Qvam at her home in Gjævran, north of Trondheim, to make sure she would be attending the upcoming meeting. In a letter dated 19 May 1908, the IWSA president wrote: 'I have not published the list of the delegates you sent me.... I notice that you put? after your name. My Dear Fru Qvam, we really could not have an international meeting without you'. ${ }^{4}$ On 30 May, she wrote again to Qvam to make sure that she would not be let down by the Norwegian delegation to the conference in the Netherlands: 'I most sincerely hope and pray', wrote Chapman Catt, 'that nothing will happen to keep our dear Fru Qvam from coming. You are the chief heroine for this meeting, and we do not like to have our play going on and our heroine away. ${ }^{5}$

Although few of the Norwegian suffragettes had the money to travel long distances and stay for weeks in hotels abroad, events turned out as the IWSA president had hoped. The leader of the Norwegian National Suffragist Association arrived in Amsterdam in time for the meeting. She also played the heroine role given to her by Chapman Catt: 'Since we met in Copenhagen, taxpaying women in Norway have obtained political suffrage', declared Qvam; 'about three hundred thousand women have entitled the vote, but 200,000 still lack it' (Report from Norway IWSA, 1908; see also Høyem, 2013: 90). At the subsequent conference in London in 1909, however, she spoke more optimistically and with greater confidence as the official representative of Norway. The attitude towards the female vote had changed considerably worldwide, she said, and 'nothing can better show the position, which women now occupy in Norway, than the fact that the government sends an official Representative over to this International Conference for Women's Rights' (IWSA, 1909; see also Høyem, 2013: 99).

The first request to the Norwegian parliament to make Qvam a formal representative at the IWSA conference had been made by Chapman Catt. Gunnar Knudsen, representing the Liberal Party, had himself made sure a royal resolution was prepared to authorize the 63-year-old Norwegian 
suffragette for the task. The financial resources she needed to travel were granted by the government, while the Ministry of Foreign Affairs issued the passport for the voyage, granting Qvam diplomatic status. ${ }^{6}$ The conclusion of her speech ensured that the Norwegian government would not regret its decision to make her an official envoy. As the wife of a former prime minister, Fredrikke Marie Qvam spoke like any statesperson tasked with ensuring that her country be both seen and recognized. She concluded:

We ought to remember, that Norway is the first sovereign state, that has given the political suffrage. And now Norway says to the other Sovereign countries; Follow our example! Make the women of your countries free Citizens. ${ }^{7}$

\section{A new arena for Nordic foreign policy}

As the American suffragist movement turned international in the early 1900s, a new arena had opened for Nordic feminists seeking to promote the cause of the female vote to their governments. The reason was that foreign examples were, as we have seen, used to urge country after country to enfranchise women. However, the Nordic countries themselves never became models for others, but the image created of them and the Nordic region by international suffragettes, since the USA could no longer play the symbolic role of frontrunner, helped the Nordic states to redefine themselves internationally. For small status-seeking countries such as Norway, feminism and women's rights even became a matter of foreign policy, something that parliamentarian Lund had first suggested in 1890. To understand this, we have to take Norway's smallness into account.

In line with Leira, smallness was the reason why Norway turned into an obsessive status-seeker towards the end of the nineteenth century, along with the recent character of the Norwegian state. Denmark and Sweden, on the other hand, both slower than Norway to make women equal citizens to men, were far more concerned about their ranking among other states and about maintaining their position - or climbing - within the international hierarchy (Leira, 2015: 22, 24). Around the turn of the century, however, the Norwegian discourse began to change. Where previously the country's primary concern was with its status as one state among others, its statusrelated talk became increasingly focused on what Norway could and should do in the world, its specific characteristics as a nation, and the qualities that defined the Norwegian people and state (Leira, 2015: 31). As in the booklet produced in 1904 by the Norwegian National Council of Women on the subject of Norway's history and politics, the imagining of Norway and Norwegians was systematically contrasted with what it meant to be Swedish.

The new international role carved out for Norway after the dissolution of the Swedish-Norwegian union was related to international law and peace, not women's rights in particular. At least, this is what researchers before 
me have stressed (Gram-Skjoldager and Tønnesson, 2008; Berg, 2016). Yet, from 1909 to 1913, Norway was officially represented at the annual conferences held by the IWSA. In addition, Chapman Catt visited Norway in 1911 on her way from Copenhagen to Stockholm, where the sixth congress of the IWSA was to take place. In the Danish capital, she was met by cabinet members and foreign legations. In the Norwegian capital, however, her welcome, according to the February 1911 report in Jus Suffragii, was as grand 'as if she had been a reigning queen'. She and her travelling partner were distinguished guests at a luncheon in which they were seated next to Gunnar Knudsen, who was now the leader of the Liberal Party. She also held a lecture in the Aula, the university hall located just opposite the Norwegian parliament, and, most importantly, was received by King Haakon VII of Norway.

As Rosland (2017) has pointed out, the IWSA president used images of Nordic royalty in strategic ways to support her movement. During a speech in London, for example, Chapman Catt announced that the queen of Norway, who was the sister of the British monarch, King George V, was supportive of the female vote. Another story she told of the Nordic royals, first published in the Belfast Weekly News, concerned the attitude of the young Norwegian Prince Olav, who, according to Chapman Catt, at the age of seven had asked his mother during a visit to England 'why uncle George did not give the vote to women of England as we have done in Norway' and 'saved all this trouble' (Rosland, 2017: 203-204, with references to Belfast Weekly News, 11 July 1911). On her visit to Norway, however, the mediaconscious suffragette met not just the king but the entire Norwegian cabinet at the reception held for her at Oslo's Grand Hotel. Wollert Konow, who was then serving as prime minster for the new conservative government, used the opportunity to entertain the guest by suggesting that the closeness of the relationship between Norway and the USA was due to the large number of Norwegian emigrants to the latter country. However, during his speech for the evening, Norway's official policy somehow slipped out as he partly took credit for the progress of women's political rights in the world. In this way, the domestic imagining of Norway was to match once again the foreign image made of the country within the international suffrage movement. The Norwegian prime minister stated:

We Norwegians consider it as an honor to have been in the front of the movement of giving political franchise to women.... If you ask me: What is your experience?... I am glad to answer: Within all parties and all fractions with us there is an overwhelming consensus of opinion that we have been right, that we have moved in the right direction.

(Nylande, 1911: 158)

In the years to come, it was not just suffragist organizations such as the IWSA that were favoured by the Norwegian government. In 1909, Norway 
would send Gina Krog as official envoy to the Toronto conference of the International Council of Women, an organization that had previously been forced to abandon the question of female suffrage owing to internal disagreements. And in 1914, the Norwegian authorities planned to co-host a larger international gathering on women's rights in the Norwegian capital, which was, however, postponed following the outbreak of World War I (Vangen, 2020). When the conference was finally held, in 1920, women's struggle for political rights had waned to some extent, however, or was increasingly blending in with women's growing engagement for peace, a development that is discussed further in Chapter 6 of this book by Inger Skjelsbæk and Torunn Tryggestad. They argue that peace and security have long been defined as constituting Norway's primary international role, and this influences how Norwegian foreign policy makes use of gender equality and how the past is evoked in current attempts to brand Norway as a 'peace nation'. Still, prior to World War I, it seems that the political rights of women were as important as peace and security for this small country concerned with its international role and status. Consequently, the gender-progressive image of the Nordic countries was at first very much based on the use of Norway as an example both by suffragist activists, on the one hand, and by the Norwegian government, on the other. Indeed, the decision to welcome Chapman Catt to Norway in 1911 was close to a stroke of genius for this brand-new state with scarce resources to impress on the international scene. Supporting the feminists' cause, if not free, was at least manageable. In the general address that Chapman Catt held in Stockholm a few months after her visit to the Norwegian capital, there were no limits to her praise:

I wish every doubting Thomas could see what I saw in Norway. More than all else, I wish the Parliaments of all nations could pay the country a visit... Norway presents an ideal example of Women suffrage in practice, and it is an achievement of which we may boast with no reservation of doubt.

(Chapman Catt, 1911)

\section{Conclusion}

Historically speaking, the Nordic countries were early to adjust to what later became the new norm of international society, including measures on women's and gender rights. However, New Zealand and Australia were the first countries in the world to introduce female suffrage at a national level. This tells us that it was the strategic meaning and role ascribed to the Nordics within the feminist movement that caused the Nordic gender image to emerge as part of women's fight for political rights. The current trend of declaring that the Nordic countries were the first in the world to do favourable things for the progression of women thus builds on much older notions or images of the gender-equal Nordics. In this process, external feminist 
actors, such as Chapman Catt, were central. Thus, the first lesson to be drawn from this chapter is that historical imaginings of the Nordic gender nation are a result of external images created and reframed over a longer period of time, which lately have been appropriated and used to the advantage of individual Nordic nation-states. Of course, authorities within the Nordic countries, including the Nordic Council of Ministers, have done their bit to put gender issues on the political agenda since the late 1960s (Larsen, 2020). However, the concern for gender equality as a Nordic image - or a Swedish, Norwegian, Icelandic, Danish or Finnish image - has increased tremendously over the last two decades. As Christopher Browning (2015: 283) has suggested, this is closely related to two connected developments: the introduction of new technologies that have helped to foster the democratization and proliferation of information and images worldwide, and the rise of nation-branding or reputation management programmes that have helped states to exert greater control over how they are seen and represented at home and abroad. In addition, global measurements within the 'index industry' have increased the circulation of the Nordic gender image. This makes it increasingly difficult to differentiate between fact and fiction in relation to the gender progressiveness of the Nordic region and countries. This situation is not helped by the fact that the Nordic states are themselves blurring the boundaries by using history to brand the nation-state in a fashion that is very selective historically speaking. The historical discourse of Nordic gender-branding has an unmistakable structure: We are best at gender equality because we were first!

The use of history in the contemporary efforts to brand individual Nordic countries as gender-equal also relates, often in intricate ways, to nation-building. A number of researchers have argued that the nation was de facto a brand already before the current trend of nation-branding began in the late 1990s (Mordhorst, 2018: 244-245). This is true, at the same time as nation-branding is about cultivating certain associations for political or commercial purposes, whether the aim of this activity is to attract foreign investment or to secure a chair at the table of powerful organizations. How this current trend relates to the building of the nation over time has not been explicitly addressed here, but the chapter does show how history was crucial for the development of the Nordic gender image. The suffragists of the early twentieth century made explicit references to the history of the Nordic countries, their stable traditions and old monarchies, to gain support for their cause and combat anti-suffragist sentiments. Interestingly, this resembles how history is being used in current Nordic gender-branding discourses, although we should be cautious about using the notion of branding avant la lettre to refer to such activities (Aronczyk, 2018: 232-233).

The Nordic gender image emerged long before nation-branding occurred as a historical phenomenon, and for this reason the concept should not be used retrospectively. In fact, none of the foreign images made of the Nordic countries a hundred years ago match the historical pasts and roles evoked 
by individual Nordic countries today. Accordingly, we might conclude that there is an interesting mismatch between the current historical imagining of the Nordic nations as gender-progressive and the foreign images made of the Nordic countries as frontrunners of women's rights within the context of international feminist activism and renewed nation-building a hundred years ago. The pasts evoked in current Nordic gender-branding are, besides, strikingly heterogeneous. Finland and Iceland flash the old past, the nineteenth century and beyond. Denmark is more focused on the twentieth century, albeit in a way that always remains very general. Norway, however, takes its reputation as a gender-equal frontrunner more for granted and concentrates on showing the world that it has always taken its international obligations on gender equality seriously. This indicates that the imagining of Norway as a peace nation trumps the type of feminist commitment that Sweden, for instance, is currently vigorously advocating.

Thus, the notion of the Nordic countries as historical frontrunners of gender equality cannot be seen only in relation to the historical achievements of the Nordic countries as gender-equal societies. As important as those achievements, it has been argued here, are the creation and circulation of domestic imaginings and foreign images that portray those countries as historical gender pioneers. Most of the time, this is done by stating that the countries were the first in the world to do beneficial things for the progression of women, fathers, gays and lesbians, or gender rights in general, accompanying this information with exact times and dates. At other times, the message is communicated without saying directly that they were gender frontrunners. This showcases the importance not only of history but also of context in Nordic gender-branding. When Norway, and not Finland, was envisioned as the ultimate number one in terms of the women's vote a hundred years ago, it was because it was thought to favour the feminist movement in charge of constructing this image and because the Norwegian authorities saw this image as beneficial for Norway's international standing. Today, Finland is the only Nordic country to make use of its historical achievements in this area in its efforts to gain legitimacy as an old gender-equal nation. This again shows that history is more than fixed time but works as a reservoir of different (national) imaginaries to be mobilized and commemorated for various purposes in the present. The Nordics were truly among the first in the world to recognize women's political rights, but the Nordic brand derived from how external feminist actors made the Nordic countries, and particularly Norway, into examples for other countries to follow. Or, in the words of Carrie Chapman Catt, speaking at the 1911 IWSA conference in Stockholm and discussing the argument of a Swedish professor who had declared that women's suffrage was a fad:

The Scandinavian people represent a race which does not forget its ancestors were Vikings, who sailed the seas without chart and compass. There are modern Vikings in all these lands as fearlessly ready to solve 
the modern problems as were those of old. It is unlikely that all the people were bold and courageous in those ancient times. There were undoubtedly pessimistic croakers who declared the ships would never return, that the men would be lost at sea, and that the enterprises were foolhardy and silly. It is the antitype of this class which we find the university professor [opposing the female vote] but we recall that it is the Vikings who are remembered today.

(Chapman Catt, 1911)

\section{Notes}

1 Greenland, the Faroe Islands and Åland are also part of the geographical and political space called Norden. This chapter, however, focuses on the five main countries.

2 'Scandinavia' now refers to Norway, Sweden and Demark only.

3 Norway enacted census-based national suffrage for women in 1907 and universal female suffrage in 1913. However, the economic requirements were maintained also after this. In 1919, receivers of poor relief were included in the polity, regardless of gender. Local suffrage followed the same pattern: In 1901, women with income above a certain threshold - or with a husband earning the same amount annually - could vote and stand for local election. In 1910, this right was made universal for all self-sustained women above 25 years of age.

4 Archive after Fredrikke Marie Qvam, Private Archive No. 5, The University Library of NTNU, Special Collection, Trondheim, Norway, Box 22: Correspondence 1908.

5 See note 4 above.

6 Archive after Fredrikke Marie Qvam, Private Archive No. 5, The University Library of NTNU, Special Collection, Trondheim, Norway, Box 23: Correspondence 1909.

7 Archive after Fredrikke Marie Qvam, Private Archive No. 5, The University Library of NTNU, Special Collection, Trondheim, Norway, Box 56: The International Woman's Suffrage Alliance, Report from Norway read by Fru F. M. Qvam on the International Woman Suffrage Alliance London Conference.

\section{References}

Andersson J and Hilson M (2009) Images of Sweden and the Nordic countries. Scandinavian Journal of History 34(3): 219-228.

Annual Report by the Norwegian National Women's Suffrage Society 1904; 1907; 1909 (Established 12. February 1889) [Årsberetning for aaret 1904; 1907; 1909 Landskvinnestemmerettsforeningen, Stiftet 12th februar 1889].

Aronczyk M (2018) Nation branding: A twentieth-first century tradition. In: Viktroin C, Guenow-Hecht JCE, Estner A and Will MK (eds) Nation Branding in Modern History. New York \& Oxford: Berghahn, 231-242.

Berg R (2016) Norsk utanrikspolitikk etter 1814. Oslo: Det norske samlaget.

Blom I (2012) Structures and agency: A transnational comparison of the struggle for women's suffrage in the Nordic countries during the long 19th century. Scandinavian Journal of History 37(3): 600-620.

Bosch M (1990) Politics and Friendship: Letters from the International Suffrage Alliance, 1902-1942. Columbus: Ohio State University Press. 
Browning C (2015) Small-state identities: Promotions past and present. In: Clerc L, Glover N and Jordan P (eds) Histories of Public Diplomacy and Nation Branding in the Nordic and Baltic Countries: Representing the Periphery. Leiden: Brill-Nijhoff, 283-300.

Chapman M (n.d.) Gender equality in Iceland. Guide to Iceland. Available at: https://guidetoiceland.is/history-culture/gender-equality-in-iceland (accessed 1 April 2020).

Chapman Catt C (1911) The world movement for women suffrage 1904-1911. Being the presidential address delivered to the Sixth Convention of the International Woman Suffrage Alliance, on Tuesday June 13, 1911 [Stockholm]. International Woman Suffrage Alliance.

Clerc L and Glover N (2015) Representing the small states of Northern Europe: Between imagined and imaged communities. In: Clerc L, Glover N and Jordan P (eds) Histories of Public Diplomacy and Nation Branding in the Nordic and Baltic Countries: Representing the Periphery. Leiden: Brill-Nijhoff, 3-20.

Danielsen H and Larsen E (2015) Likestillingslandet Norge 1990-2013. In: Danielsen H, Larsen E and Owesen IW (eds) Norsk likestillingshistorie. Bergen: Fagbokforlaget, 186-219.

Danielsen H, Larsen E and Owesen IW (2015) Norsk likestillingshistorie. Bergen: Fagbokforlaget.

Denmark. $d k$ (n.d.) Income and gender equality in Denmark. Available at: https:// denmark.dk/society-and-business/equality (accessed 1 April 2020).

DuBois E (1997) Feminism and Suffrage: The Emergence of an Independent Women's Movement in America, 1848-1869. New York: Cornell University Press.

Florin C (2018) Visioner, rörelser och rötsträtt. In: Holgersson U and Wängnerud L (eds) Rösträttens århundrade. Kampen, utvecklingen och framtiden för demokratin i Sverige. Stockholm: Makdams Förlag, 29-63.

Finnegan M (1999) Selling Suffrage: Consumer Culture and Votes for Women. New York: Columbia University Press.

Government of Iceland (2019) Iceland remains the top country on the World Economic Forum's gender gap index. 18 December. Available at: https://www. government.is/diplomatic-missions/embassy-article/2019/12/18/Iceland-remainsthe-top-country-on-the-World-Economic-Forums-index-for-gender-parity/ (accessed 1 April 2020).

Government Offices of Sweden (n.d.) A feminist government. Available at: https:// www.government.se/government-policy/a-feminist-government/ (accessed 15 May 2020).

Government.no (2019) Sexual orientation, gender identity and gender expression. Last updated 14 December 2019. Available at: https://www.regjeringen.no/en/topics/ equality-and-social-inclusion/likestilling-og-inkludering/seksuell-orienteringkjonnsidentitet-og-kjonnsuttrykk/id2005942/ (accessed 14 April 2020).

Government.no (2020a) Women's rights and gender equality. Last updated 1 December 2020. Available at: https://www.regjeringen.no/en/topics/foreign-affairs/ the-un/innsikt/womens_rights/id439433/ (accessed 14 April 2020).

Government.no (2020b) Gender equality. Last updated 11 March 2020. Available at: https://www.regjeringen.no/en/topics/equality-and-social-inclusion/likestillingog-inkludering/gender-equality/id670481/ (accessed 15 April 2020).

Gram-Skjoldager K and Tønnesson Ø (2008) Unity and divergence: Scandinavian internationalism 1914-1921. Contemporary European History 17(3): 301-332. 
Hagemann G (2009) To become a political citizen. In: Sulkunen I, Nevala-Nurmi S-L and Markkola P (eds) Suffrage, Gender and Citizenship: International Perspectives on Parliamentary Reform. Newcastle upon Tyne: Cambridge Scholars Publishing, 120-145.

Høyem A (2013) Fra tvil til triumf. Kvinnebevegelsens internasjonale engasjement 1884-1913. Master's thesis, University of Oslo.

Iceland.is (n.d.) Gender equality in Iceland. Available at: https://www.iceland.is/ press/press--media-kit/gender-equality-in-iceland/ (accessed 1 April 2020).

International Woman Suffrage Alliance (IWSA) (1902) Report of First International Woman Suffrage Conference held at Washington, USA, February 12-18. New York: IWSA Headquarters.

International Woman Suffrage Alliance (IWSA) (1908) Report of Fourth Conference Amsterdam, Holland, June 15-20. Amsterdam: IWSA/F. Van Rossen.

International Woman Suffrage Alliance (IWSA) (1909) Report of Fifth Conference and First Quinquennial, London, England, April 26-May 1. London: Samuel Sidders \& Co.

International Woman Suffrage Alliance (IWSA) (1913) Report of Seventh Congress, Budapest, Hungary, June 15-21. Manchester: Percy Brothers Ltd \& the Hotspur Press.

Jus Suffragii [the official periodical of the IWSA] 1906-1914, LSE Digital Library. Available at: https://digital.library.lse.ac.uk./browse\#jussuffragii.

Klejman L (1989) Les congrès Féministes internationaux. Mil neuf cent. Revue d'histoire intellectuelle, (7) Fait partie d'un numéro thématique Les congrès lieux de l'échange intellectuel 1850-1914, 71-86.

Kolstad E (ed.) (1963) Utsnitt av lovforslag, komité-innstillinger og debatter i Stortinget om stemmerett for kvinner 17. Mai 1814-11. Juni 1913. Oslo: Stortinget.

Krog G (1902) Telegram to the IWSA, Washington, DC.

Lagerlöf S (1911) Home and state. Being an address delivered at Stockholm at the Sixth Convention of the International Woman Suffrage Alliance, June 1911. International Woman Suffrage Alliance.

Larsen E (2013) Stemmerett til alle! In: Danielsen H, Larsen E and Owesen IW (eds) Norsk likestillingshistorie (first and extended edition with illustrations). Bergen: Fagbokforlaget, 160-218.

Larsen E (2015) Stemmerett til alle! In: Danielsen H, Larsen E and Owesen IW (eds) Norsk likestillingshistorie. Bergen: Fagbokforlaget (second edition, paperback), 89-121.

Larsen E (2020) State feminism revisited as history of knowledge: The case of Norway. In: Östling J, Olsen N and Heidenblad DL (eds) Histories of Knowledge in Postwar Scandinavia: Actors, Arenas, and Aspirations. London: Routledge, 152-169.

Larsen E and Øksendal LF (2013) De glemte kvinnevalgene. Historisk tidsskrift 92(4): 563-590.

Leira H (2015) The formative years: Norway as an obsessive status-seeker. In: De Carvalho B and Neumann IB (eds) Small State Status Seeking: Norway's Quest for International Standing. London \& New York: Routledge, 22-41.

Luno B (1906) Report Second and Third Conferences of the International Woman Suffrage Alliance, Berlin, Germany 3-4 June 1904, Copenhagen, Denmark 7-11 August 1906, Copenhagen. 
McDonald C (2009) Suffrage, gender and sovereignty in New Zealand. In: Sulkunen I, Nevala-Nurmi S-L and Markkola P (eds) Suffrage, Gender and Citizenship: International Perspectives on Parliamentary Reform. Newcastle upon Tyne: Cambridge Scholars Publishing, 14-33.

Marklund C (2009) The social laboratory, the middle way and the Swedish model: Three frames for the image of Sweden. Scandinavian Journal of History 34(3): 264-285.

Marklund C (2017) The Nordic model on the global market of ideas: The welfare state as Scandinavia's best brand. Geopolitics 22(3): 1-17.

Ministry of Social Affairs and Health, Finland (n.d. a) Frontpage. Available at: https://stm.fi/en/frontpage (accessed 10 March 2020).

Ministry of Social Affairs and Health, Finland (n.d. b) Finland is a gender equality pioneer. Available at: https://stm.fi/en/Finland-is-a-gender-equality-pioneer (accessed 15 April 2020).

Mordhorst M (2018) The history of nation branding and nation branding as history. In: Viktroin C, Guenow-Hecht JCE, Estner A and Will MK (eds) Nation Branding in Modern History. New York \& Oxford: Berghahn, 243-254.

Morning A (ed.) (2006) Kön och politik. 100 år av kvinnelig rösträtt i Finland. Helsingfors: Helsingfors Förlagsaktiebolaget Otava.

Nora P and Kritzman LD (eds) (1996) Realms of Memory: Rethinking the French Past. New York: Columbia University Press.

Nordic Co-operation (n.d.) Gender equality and LGBTI. Available at: https://www. norden.org/en/gender-equality-and-lgbti (accessed 10 March 2020).

Norwegian National Council of Women (1905) Norway: A Few Facts from Norwegian History and Politics. Addressed to the International Council of Women by the Norwegian Council of Women. Christiania: Printed by A. W. Brøgger. Available at: https://archive.org/details/norwayafewfacts00womegoog/page/n2/mode/2up (accessed 8 July 2020).

Nylande (1911) Speeches during Mrs. Chapman Catt's Stay in Norway, Journal for the Norwegian feminist organization. No. 10, 15 May: 156-161.

Offen K (2000) European Feminisms, 1700-1950: A Political History. Stanford, CA: Stanford University Press.

Oldfield A (1992) Woman Suffrage in Australia: A Gift or a Struggle? Cambridge: Cambridge University Press.

Paxton P, Hughes MM and Green JL (2006) The international women's movement and women's political representation, 1893-2003. American Sociological Review 71(6): 898-920.

Rosland S (2017) Norway as an example in the UK women's suffrage campaign. NORA - Nordic Journal of Feminist and Gender Research 25(3): 195-210.

Rupp LJ (1997) Worlds of Women: The Making of an International Women's Movement. Princeton, NJ: Princeton University Press.

Skjelsbæk I and Tryggestad TL (2021) Protecting the brand: The hesitant incorporation of gender equality in the peace nation. In: Larsen E, Moss SM and Skjelsbæk I (eds) Gender Equality and Nation-Branding in the Nordic Region. Abingdon: Routledge, 113-133.

Somervill BA (2003) Votes for Women! The Story of Carrie Chapman Catt. Greensboro, NC: Morgan Reynolds Publishing.

Sulkunen I (2009) Suffrage, nation and political mobilisation: The Finnish case in an international context. In: Sulkunen I, Nevala-Nurmi S-L and Markkola P 


\section{Eirinn Larsen}

(eds) Suffrage, Gender and Citizenship: International Perspectives on Parliamentary Reform. Newcastle: Cambridge Scholars Publishing, 83-105,

Sulkunen I (2015) An international comparison of women's suffrage: The cases of Finland and New Zealand in the late nineteenth and early twentieth century. Journal of Women's History 27(4): 88-111.

Towns A (2009) The status of women as a standard of 'civilization'. Journal of International Relations 15(4): 681-706.

Towns A (2010) Women and States: Norms and Hierarchies in International Society. Cambridge: Cambridge University Press.

Towns A (2014) Manning the state: European early-nineteenth-century masculinities in the new Norway of 1814. NORA - Nordic Journal of Feminist and Gender Research 22(2): 116-130.

Vandapuye HO (2016) Brende med ambisiøs likestillingsplan. Bistandsaktuelt, 4 June. Available at: www.bistandsaktuelt.no/nyheter/2016/handlingsplan-for-likestilling (accessed 15 January 2020).

Vangen AJ (2020) Gender Equal Forerunners? Images and Imaginings of the Nordic Countries in the International Women's Suffrage Movement 1902-1914. Master's thesis, University of Oslo.

Varga S (2013) The politics of nation branding: Collective identity and public sphere in the neoliberal state. Philosophy and Social Criticism 39(8): 825-845.

Werron T (2014) On public forms of competition. Cultural Studies - Critical Methodologies 14(1): 62-76.

Zalis S (2018) Lessons from the world's most gender-equal countries. Forbes, 30 October. Available at: https://www.forbes.com/sites/shelleyzalis/2018/10/30/lessonsfrom-the-worlds-most-gender-equal-countries/\#721ece3a7dd8 (accessed 15 June 2020). 


\title{
2 Variations on shared themes Branding the Nordics as gender equal
}

\author{
Katarzyna Jezierska and Ann Towns
}

\begin{abstract}
Differentiation is at the core of nation-branding. As branding scholar and consultant Keith Dinnie (2008: 139) has argued, 'governments around the world are turning to branding techniques to differentiate their nations on the global stage and also to give themselves a competitive edge over rival countries with which they must compete in both international and domestic markets'. This urge to differentiate presents a challenge for Nordic states, perhaps particularly when it comes to gender equality. On the one hand, there is now an effort to launch a 'Nordic' brand as a single and unified concept that includes all the Nordic countries. The Nordic Council of Ministers presented a branding strategy for the Nordic region in 2015, the aim being to 'promote what we have in common - our Nordic perspective, our values, and a culture that has grown out of a common history' (Nordic Council of Ministers, 2015: 5). Gender equality is featured as a central pillar in this common branding effort as a set of values, policies and practices that unifies the Nordic region and sets it apart from the rest of the world. On the other hand, each Nordic state still engages in its own nation-branding, and gender equality is a potential feature for each of these states. Nation-branding generally requires that each state presents itself as distinctive and even unique. Rather than a uniform narrative about Nordic gender equality across the individual brands, there is thus an incentive for each state to highlight its own unique traits. The question is what qualities the Nordic countries emphasize in their efforts to brand their respective nations gender equal?

The aim of this chapter is to examine and compare the gender equality components of the branding efforts of Denmark, Finland, Iceland, Norway and Sweden. The approach adopted is primarily descriptive, the intention being to provide a comparative examination of the Nordic brands that can provide a wider context for the other chapters in this volume. Do the countries brand themselves in similar ways in terms of gender equality, as the Nordic Council of Ministers has recommended? Or do they attempt to carve their own niches in the international distinction game, as Larsen (see Chapter 1 in this volume) suggests? Do their branding efforts differ in terms of how and to what extent gender equality is emphasized? If so, in what ways does each country claim and feature gender equality as a national
\end{abstract}


trait? While our theoretical point of departure is critical - the function of our analysis is neither to legitimize branding as a practice nor to help improve Nordic branding - the description of the various countries' branding efforts is merely a first step necessary for a future critical analysis that would unpack the underlying assumptions and power dynamics inherent in these branding practices. The comparison of the brands makes it possible to consider opportunities that may have been missed in particular brands, ways in which gender equality could have been incorporated but was not. Identifying missed opportunities, however, does not mean making suggestions about what branding should have included. Again, our aim is to highlight differences and similarities rather than to advance particular visions of Nordic brands.

The analysis relies on three kinds of data: (1) secondary sources, to piece together a brief history of the nation-branding efforts of each country; (2) brand platform documents, if they exist and are publicly available, as part of each country's nation-branding history; and (3), most importantly for the analysis of gender equality in each brand, national websites. ${ }^{1}$ Nationbranding is obviously much more than the texts and images presented on official websites. Nonetheless, these websites are deliberately and carefully crafted to convey the simple and distinctive messages about national traits that form the core of each national brand. While not comprehensive, we thus approach these sites as a shortcut to the brand each state seeks to promote and project. Since Norway does not use its official country website Norway. $n o$ as a general branding platform (it serves as a portal to the embassies and missions of the Norwegian Foreign Service), our analysis of Norway is primarily focused on the tourism promotion and travel guide Visitnorway.no. The branding of Norway is thus not entirely comparable to the other Nordic countries, but we have opted to include Norway in the analysis nonetheless, bearing this difference in mind.

The methodology used is a standard discourse analysis of the texts of the Nordic country websites. On each website, we began with a general orientation, looking at the organization of the website and the main branding message. Discerning the main branding message is not rocket science - the whole point of these sites is to present clear and obvious narratives about the nation. We then used the search engines provided at these sites to find gender-related articles, using the search terms 'gender', 'women', 'women's rights', 'gay rights', 'LGBTQ' and 'masculinity'. We read all articles containing any of these terms carefully, to discern in what ways gender is presented as part of a particular country's brand. The data collection was carried out in 2018 - the websites may have changed since then.

The concern with the nation's image abroad is not a new one: Nordic states have consciously managed their reputations abroad for at least a century. For instance, the Swedish Ministry for Foreign Affairs (MFA) founded its Press Department in 1909 explicitly to 'remind the world about Sweden', 
and it also deployed journalists in Paris, London and Berlin to feed news stories about Sweden to foreign news outlets (Pamment, 2013: 100).

The boom in nation-branding campaigns seems to have occurred in the early to mid-2000s (Teslik, 2007), which is also the period in which the Nordic states first launched 'national brands'. The five states have nonetheless approached nation-branding quite differently, with Finland, Sweden and to some extent Iceland having developed much more coherent, distinctive and institutionalized brands than Denmark and Norway. As we will show below, branding efforts in Denmark and Iceland were triggered and speeded up by sudden events - the 2006 Muhammad cartoon crisis in the case of Denmark, the 2008 economic crises and the 2010 eruptions of volcanic ash in that of Iceland - whereas branding initiatives in the remaining three countries developed as a result of more general and less urgent concerns with the global standing of the respective 'national brands'. As we will demonstrate in the following sections, the roads and approaches to nation-branding vary significantly among the five countries, as does the position of gender equality therein.

In sum, the comparison conducted in this chapter shows that the five Nordic brands rest on similar foundations. They all emphasize egalitarian and progressive values, laws and institutions; and they all highlight the natural environments of their respective countries. In this normative setting, all five brands furthermore include narratives about gender equality and LGBTQ rights. However, they do so to remarkably different degrees. Whereas Sweden centrally features gender equality in virtually all its branding efforts, neither Denmark nor Norway places much emphasis on gender equality at all. Finland and Iceland emphasize gender equality less consistently than Sweden, but when they do emphasize it, they do so forcefully, setting the countries up as gender-equality leaders. Visually and in text, men and women are generally presented in non-stereotypical roles: the nurturing side of men as fathers and caretakers is highlighted, and the innovative and physically forceful side of women is stressed. None of the brands are starkly heteronormative. Other than on the tourism sites, there are few images of heterosexual families and couples, for example, and most images are 'sexuality-neutral'. However, Denmark and Iceland hardly feature LGBTQ rights at all, whereas Finland, Norway and Sweden do so more extensively.

The rest of this chapter is made up of five sections in which we compare the Nordic countries in terms of the extent to which and how gender equality features on their nation-branding websites. We will begin with a discussion of Denmark and Norway, which do the least to incorporate gender equality into the national brand, before moving on to Sweden, the gender-equality branding champion. Once we have looked at these three, Finland and Iceland are discussed. We have labelled each brand in an attempt to synthesize the main message of each national platform, and we use these labels as titles for each individual section. The chapter concludes with a more extensive discussion that summarizes our analysis. 


\section{Trusting Denmark}

In 2007, Denmark launched its first explicit 'nation-branding' initiative, entitled the 'Action Plan for the Global Marketing of Denmark', to guide nation-branding until 2012. At this time, Denmark was reeling from the Muhammad cartoon crisis that had erupted in early 2006 and involved global protests and boycotts of Danish products as a result of the 2005 publication of cartoon caricatures of the prophet Muhammad in the major Danish daily paper Jyllands-Posten. Facing demands from the Danish business sector that diplomacy and other tools of political dialogue be used to mitigate the crisis, the government established a nation-branding programme to rebuild Denmark's image (Angell and Mordhorst, 2015: 190). The Ministry of Economics and Business Affairs was assigned leadership of the programme, with four additional ministries participating in the taskforce: the Ministry of Foreign Affairs; the Ministry of Science, Technology and Innovation; the Ministry of Education; and the Ministry of Culture. The business sector, however, never became centrally involved in the actual planning and execution of the brand (Angell and Mordhorst, 2015: 191).

Marketing consultants from Red Associates were hired by the Ministry of Economic and Business Affairs to develop a brand platform, resulting in the report Perceptional Analysis and Recommendations for an Aggressive Global Marketing of Denmark (Red Associates, 2006). The development of this brand platform was subjected to political negotiations (Mordhorst, 2015: 252). As a result, rather than one core message and a single brand vision, Red Associates proposed a platform centred on four themes: 'Responsible and Balanced', 'High Quality', 'Experimental and Proactive' and 'Environmental Awareness, Simplicity and Efficiency'. This was a fragmented and internally contradictory platform that was difficult to implement as a coherent narrative (Mordhorst, 2015: 252). The programme was evaluated in 2010, and it was concluded that, despite major efforts, the international visibility and strength of the Danish brand had not improved to any significant degree (Csaba and Stöber, 2011). The nation-branding initiative was subsequently terminated in 2012 (Merkelsen and Rasmussen, 2015: 192).

There is no contemporary national brand document coordinating the presentation of the country image of Denmark. ${ }^{2}$ Branding efforts are coordinated by the Department of Public Diplomacy, Press and Communication of the Danish MFA in collaboration with Danish diplomatic representations worldwide (Merkelsen and Rasmussen, 2015: 192). This department also maintains the official website, Denmark. $d k$, which is designed to 'tell you the story about Denmark.' Denmark's national brand is much less established than those of Sweden or Finland, and international surveys indicate a lack of familiarity with Danish corporate brands and with Denmark more generally (Cremer, 2016) - or, as summarized by two analysts, 'Copenhagen is hot, Denmark is not' (Csaba and Stöber, 2011). Not surprisingly, there have been calls from the Danish business sector for a new, concerted 
national branding strategy. As a representative from the Confederation of Danish Industry has argued, 'we have to treat Denmark as if it were a business: draw up a plan, invest in it, follow up on it, adjust it and measure our results' (Csaba and Stöber, 2011).

On Denmark.dk, the brand message is one that emphasizes the welfare state and social trust in a national community. Trust, community and welfare hang together, we are told, and Danish society functions so well because they are so tightly interwoven within it. In explaining universal healthcare, education and other benefits of the welfare state, the text elaborates that

the idea is that everyone must contribute to the community and in return, the community will help care for all. These values of trust and community are deeply embedded in Danish culture and society and have their roots in Danish history.

(Denmark.dk, n.d. a)

Why is Denmark a great place to live? Because of trust, community and the welfare state (Denmark.dk, n.d. a). 'Why are Danish people so happy?' Because of trust, community and the welfare state (Denmark.dk, n.d. b). Why is Denmark such 'a great place to do business'? Because of trust, community and the welfare state.

An article entitled 'Trust: A Cornerstone of Danish Culture' asks the (perhaps rhetorical) question, 'Why are the Danes so trusting?' The reader is provided with a tautological claim: that Danes are trusting because there is a Danish culture of trust - trust is a 'culturally-determined phenomenon built over time. Trust is learned during childhood from parents, teachers, and coaches, lasts for a lifetime and is passed on from generation to generation' (Denmark.dk, n.d. c). Indeed, the text on Denmark. $d k$ is infused both with implicit assumptions and overt claims about the existence and importance of a cohesive and distinctive Danish national community. Not surprisingly, and in stark contrast with Swedish branding efforts, the Danish site makes not one mention of multiculturalism. The monocultural nature of the Danish nation is reinforced visually, with images representing Denmark as a white community with very few people of colour. To be sure, there is one article on religion in Denmark that makes mention of Muslims and Jews and features a photo of three little girls, and the one in the middle is wearing a headscarf (Denmark.dk, n.d. d). But this brief discussion follows a much longer one describing Denmark as a Christian country.

So how is gender equality fitted into the Danish national narrative about trust, community and the welfare state? Visually, the Danish site looks similar to the other Nordic ones. There are both men and women depicted throughout, and they are often depicted in non-stereotypical ways. For instance, the majority of the images of a parent and a child feature fathers rather than mothers. However, interestingly, gender equality or the status of women is hardly featured at all textually. In fact, on Denmark.dk, there 
is only one article - on the broader theme of equality - that devotes a few short paragraphs explicitly to 'Gender Equality in Denmark' as well as a few on 'LGBT Rights in Denmark' (Denmark. $d k$, n.d. e). There is one additional paragraph describing women's higher rates of paid employment in Denmark, in an article on work-life balance (Denmark. $d k$, n.d. f), and a few scattered sentences on women here and there. Overall, gender equality has a miniscule presence within the Danish online brand.

In the article on equality, we learn that equality is a central feature of Danish culture, with low income inequality and low poverty rates being characteristic traits of Danish society. Gender equality and LGBTQ rights are discussed as dimensions of this general cultural trait. In contrast with Sweden and Finland, as we will show below, the claims about gender equality in Denmark are furthermore modest, presented as brief, matter-of-fact statements. For instance, the reader is told that 'Denmark scores well on the World Economic Forum's gender equality index' and that 'women are well represented in Denmark's government'. Claims about LGBTQ rights are equally downplayed and modest. Statements about equality of samesex partners before the law and of Copenhagen being one of the most gayfriendly cities in the world are made, but the overall message that 'being gay in Denmark is no big deal' is made by hardly featuring LGBTQ issues or gay life at all.

That said, Denmark - like the other Nordic states - is presented in terms of a few gender-equality 'firsts': Nina Bang becoming 'the world's first female minister in a country with parliamentary democracy' in 1924 (Denmark.dk, n.d. e); Asta Nielsen being Europe's first female movie star (Denmark.dk, n.d. g); and Christine Jorgensen receiving 'one of the first internationally-discussed gender reassignment surgeries in 1951' (Denmark. $d k$, n.d. e). Overall, however, it is remarkable how little emphasis is placed on showcasing gender equality and how many opportunities for doing so are overlooked. For instance, in the discussion of Denmark as a Christian country, one brief sentence states that 'more than $55 \%$ of the priests in the state church are women' (Denmark.dk, n.d. d). Given the lack of women priests in most other Christian denominations, this could have been an opportunity to emphasize Danish progressiveness on gender. Likewise, the discussion of Danish foreign policy and aid says virtually nothing about the integration of gender equality into Danish foreign aid (Denmark.dk, n.d. h). There is nothing on women or gender in the section on government and politics. Clearly, and in stark contrast with the Swedish brand, as we will show below, gender equality is briefly mentioned but not featured in the branding narrative about Denmark.

\section{Natural Norway}

Norway seems to have started working towards a national brand earlier than neighbouring states, and yet these efforts never resulted in a coordinated 
brand platform or an institution charged with managing a Norwegian 'brand'. The MFA took a leading role in starting the process, preparing three reports on Norway's image abroad between 1999 and 2006 (Lending, 2000; Omdømmeutvalget, 2006). These reports called for a coherent branding of Norway executed through coordinated national reputation management. Two consecutive bodies were established to meet these expectations: the Norwegian Public Diplomacy Commission (mdømmeutvalget) that functioned during 2004-2006 and the Norwegian Public Diplomacy Forum (mdømmeforumet) that was in operation from 2007 to 2010. Both were led by the foreign minister and included a broad spectrum of representatives from the private sector, the cultural sector, academia and various NGOs. Angell and Mordhorst (2015: 192) argue that 'national reputation efforts in the Norwegian setting were an integrated part of the foreign policy realm and have not caused significant controversies'.

Ultimately, despite the early initiatives towards a branding platform, Norway did not end up with an explicit and coherent brand that is officially promoted. As the Foreign Ministry explains, 'we are not seeking to convey a fixed message, like a slogan, but rather to stake out a certain direction in our continued efforts to promote Norway'. According to the Foreign Ministry, that general message is that Norway should be seen as an 'attractive, strong and committed partner' and that the world should know more about Norwegian culture and 'our relationship with nature' (Government.no, 2013). The official country website of Norway, Norway.no, is used as a portal to Norway's diplomatic missions abroad rather than as an information site and country-branding tool. This sets Norway apart from all of its Nordic neighbours. In the absence of a single online focal point, the online management of Norway's reputation abroad is spread over many official websites, including the official government website, ${ }^{4}$ diplomatic mission websites, ${ }^{5}$ the official tourism website, ${ }^{6}$ the official site for studying in Norway ${ }^{7}$ and Innovation Norway, a site for promoting business in Norway. ${ }^{8}$ The other Nordic states of course also maintain these kinds of websites, and they also engage in some nation-branding in them, too. But they centre their branding efforts on their official country websites in a way that Norway does not. Like the other Nordic states, Norway also has a resource base for public diplomacy developed for 'missions abroad and other relevant actors when they need to tell others about Norway', which allegedly includes images, a story bank and presentations (Government.no, 2015). However, the Norwegian resource base is not publicly available. Below, we will focus our analysis primarily on the tourism site Visitnorway.com, using the other, less-developed websites at times for additional illustrations.

It is difficult to get a coherent sense from all of these websites of any core messages about Norway. That said, a 2009 report recommended that Norway be branded as 'a resourceful, committed and reliable partner' (Synovate, 2009). This is still the main message that the Ministry of Foreign Affairs claims to want to use in Norwegian public diplomacy: 'We would like our 
contacts to perceive us as: a resourceful, engaged and reliable partner.' The Norwegian MFA still wants official communication efforts to pivot around two main dimensions: 'Norwegian culture and our relationship with nature'. Norwegian nature is presented as both 'magnificent and accessible' and as a great resource for wealth generation and technological development. Norwegian culture, on the other hand, is coupled with the welfare state, quality of life and egalitarianism (Government.no, 2013).

Gender equality is not mentioned explicitly by the MFA as part of the core public diplomacy message. And gender equality does not seem to feature centrally on any of the official sites (other than the government site, of course, which discusses gender-related public policy along with other policy). To be sure, as in Denmark, gender equality is mentioned here and there in more general discussions of Norwegian egalitarianism. For instance, in an article on Norwegian society on the Study in Norway site, readers are told that

Openness, equality and equal rights in general - such as economic, social and gender equality - are important values to most Norwegians.... Homosexual relations, for instance, have been legal since 1972, and same sex couples have been able to adopt children and get married since 2009 .

As on the other Nordic sites, the caretaking role of fathers is highlighted. Under an image with the title 'Dad hugging his baby', we learn that

Systematic efforts are made to ensure that women and men are equal when it comes to education and wages. This has certainly changed the Norwegian male's role as a father. Norway has a paternity leave quota [... it's easier] to combine careers and family. Nevertheless, the goal of total equality remains.

(Study in Norway, n.d.)

Visitnorway.com, Norway's official travel guide, is clearly tourist-oriented, comprising mostly information about how to get there, where to stay and what to eat. However, there is also some messaging about the country. The slogan 'Norway powered by nature' is used in the logo, in line with the core brand message. Throughout, the website is full of beautiful visual representations of nature, which is to be expected from a travel site. There is frequent use of videos narrating personalized stories about Norway through food, nature, etc. (e.g. 'Find inspiration in our stories from Norway. Meet the locals and get tips from experts and insiders'; see Visitnorway.com, n.d. a). Both men and women are featured in these films; however, in videos featuring single individuals, men dominate as protagonists by a ratio of 4:1. Nature and different tourist attractions are presented through the 'eyes' of young, heterosexual couples. Avoiding representations of nature as empty 
swaths of land seems to directly follow the advice from a 2003 external report on Norwegian public diplomacy:

In portraying peace and nature, Norway should abjure the static landscape, the romanticized anti-modern images of spaces empty but for the occasional troll, and the depictions of an innocuous faraway place. The expression should focus on the dynamic - active people, hardheadedness and modernity.

(Leonard and Small, 2003).

In this way, the land shots avoid the male-explorer gaze. The texts accompanying the videos, however, frequently use words such as 'explore', 'experience', 'discover', all alluding to lust and pleasure.

There are no explicit discussions of gender equality on Visitnorway.com. One article entitled 'Women's Museum' presents a museum dedicated to the history of women up to the present time (Visitnorway.com, n.d. b). There is no mention of what specific feminist struggles are highlighted or what achievements are celebrated in this museum. If 'gender' is mentioned at all on the website, it is simply listed as one of various ascriptive criteria, as an expression of the non-discriminatory character of Norwegian society. For example, we read that among the guests at Park Café there are people of 'all ages, genders, nationalities, titles and types', that 'age and gender set no limits' for the adventurous trips promoted on the website, or, alternatively that 'disc golf is a recreational sports for everyone, regardless of age, gender, or ability'.

In contrast, some effort is made to present Norway as an LGBTQ-friendly travel destination, as summarized in the slogan 'Open landscapes, open minds'. The article 'LGBTQ+ Travel' features the story of two couples who came to Oslo for the Pride festival. We learn that

like its Nordic neighbours, most Norwegians have a liberal attitude towards LGBTQ people, and the country was among the first to enact antidiscrimination laws against gays and lesbians. In fact, Norway ranks as third best in the ILGA-Europe 2018 rating of 49 European countries.

(Visitnorway.com, n.d. c)

A queer person interviewed in the article assures us that 'in many ways, we live in a dreamland', even though there is an admission that 'parts of Norway are still very far behind'.

There are themes on the website in which one could expect more explicit discussion of gender equality. For instance, an article labelled 'The Happiest Country on Earth' boasts about the fact that in 2017 Norway jumped to the first place in the ranking of the world's happiest countries in the United Nations' World Happiness Report (Visitnorway.com, n.d. d). Since the article elaborates on several reasons behind this high result, we might expect 
gender equality to be included as an important aspect explaining the "happiness' of Norwegians. However, among the many factors listed, such as a well-functioning welfare and healthcare system or the fact that 'our society is rather safe and harmonious', gender equality is not mentioned. It only appears in passing when we learn that in the aftermath of the 2011 terrorist attacks in Norway, the daily paper Aftenposten invited its readers to list things they appreciate about Norwegian society. Among the most popular contributions, fifth (out of 12) was 'that everyone has the same opportunity to succeed, get an education and become what they want, without regard to gender, economy and background' (Visitnorway.com, n.d. d). Yet again, gender is presented as one among several other characteristics that showcase Norwegian openness.

It should not be forgotten that while the absence of any other official country website makes Visitnorway.com function as the deputy gateway to Norway, it is nevertheless a travel site, and Sweden's official tourist website, Visitsweden.com, also has virtually no references to gender equality. Like its Norwegian counterpart, too, the latter has a specific section entitled 'LGBT+ Sweden' (Visitsweden.com, n.d. a), though Sweden's efforts to attract this specific category of tourists go even further than the Norwegian site - the section takes us to a separate website specifically designed as an 'inspiration for gay and lesbian travellers to Sweden' (Visitsweden.com, n.d. b).

\section{Progressive Sweden}

Sweden has one of the most integrated and well-developed national brands of the Nordic countries, and its ongoing platform has a relatively long history (Clerc et al., 2015; Marklund, 2017). In 1995, the Swedish government created a task group - the Council for the Promotion of Sweden (bringing together actors from the Ministry for Foreign Affairs, the Ministry of Enterprise and Innovation, and Business Sweden) - to effectively promote Sweden in a coordinated, long-term manner. The emergence of selfconscious 'nation-branding' - in corporate language that draws parallels between the nation and a corporation with a 'brand' to manage - can be traced back to a 2003 study called Sweden's Image Abroad, commissioned by the Council for the Promotion of Sweden (NSU). Apart from the Council, the Swedish Institute, a body led by the Ministry of Foreign Affairs that coordinates public diplomacy promotional resources in trade, investment, export and tourism, has overall responsibility for Swedish public diplomacy. The aim of the Swedish Institute (n.d.) is to 'promote Sweden and Swedish issues globally' and to work 'with Sweden's image abroad'. A broad consultation process starting in 2005, which involved many stakeholders and promotional bodies, resulted in the 2007 launching of a common brand platform - a simplified and coherent set of concepts that are to serve as the foundation in communication about Sweden. The Council launched the new brand platform with great fanfare, with Swedish public TV broadcasting a 
four-hour VIP event over the internet (Pamment, 2013: 100). According to Pamment (2013: 99), 'Brand Sweden represents an ambitious government led consensus that few other democratic states would be able to hold together'. Despite the ambition to forge a broad consensus behind the brand, some dissenting voices were heard from academics and cultural commentators who found the bombastic claims about national distinctiveness and corporate imagery laughable (Pamment, 2013: 101). Since 2007, both the Swedish Institute $(2007,2008)$ and the NSU $(2009,2014 a, 2014 b, 2017)$ have issued a number of reports upgrading and refining Brand Sweden.

The brand platform permeates the country website Sweden.se. The core concept to be associated with Sweden, we learn from the Swedish brand platform, is 'progressive' (Swedish Institute, 2007). There are four components of the brand platform: Sweden as an 'innovative', 'open', 'caring' and 'authentic' country (Swedish Institute, 2007). These are clearly streamlined on the site. The brand rests on a seductive mix of progressive values and trendy magazine aesthetics, seamlessly weaving messages about innovation, inclusiveness, equality and the environment into a coherent story about a country at the forefront of the move towards a better future. Multiculturalism and openness to the world are central to the visual presentation. Around a fourth of the people portrayed are people of colour, which roughly corresponds with the national average in Sweden. Of the Nordic visual presentations on the country webpages, this is the most diverse national brand.

Gender equality and, to a lesser degree, LGBTQ rights are central pillars in this progressive story, which resonates with the feminist foreign policy adopted by the Swedish government in 2014. In the work leading up to the present branding strategy, gender equality was identified as one of the themes most closely associated with Sweden in populations around the world (Swedish Institute, 2007). This is clearly reflected on the country website. As a whole, the site imagery by and large tells a story that up-ends gender stereotypes, one of economically active women and caring fathers, with a few non-binary and gender-fluid inserts. The images of sports, science and innovation often feature women, whereas tabs and imagery with small children almost exclusively feature fathers. 'Swedish dads' are depicted as being on parental leave and generally involved in the care of their children, whereas the reality of Swedish men on average only taking $28 \%$ of the parental leave that couples are entitled to is not portrayed (Försäkringskassan, 2018). The parental involvement of Swedish men plays an important part in the branding efforts. The focus is dual: on women in the workforce, politics or science, on the one hand, and on men as diaper-changing, vomit-wiping and sometimes stay-at-home caretakers, on the other.

Gender equality is one of the explicit tags on the website, and there are also tags for information about Sweden as a family-friendly country ('Family-Friendly Life the Swedish Way') and 'Children in Sweden'. The article 'Gender Equality in Sweden' highlights important issues crucial for achieving gender equality: power and influence, economic equality, work 
and family, and men's violence against women. For the most part, Sweden is presented as highly advanced in relation to these issues. Like Finland, as we will see below, Sweden is also represented as an international role model on gender equality: 'An extensive welfare system that promotes a healthy work-life balance has been an important factor in making Sweden a genderegalitarian leader,' the reader learns (Sweden.se, n.d. a). Although the site in essence presents Sweden as a gender utopia, there is simultaneously some hesitation about being boastful. Indeed, the site contains many disclaimers of the kind that 'Sweden is not perfect, but...'. One typical passage reads, 'Often considered a gender equality role model, Sweden has come a long way. Still, there's room for improvement' (Sweden.se, n.d b). There are a few critical passages that point to problems. For instance, 'Gender Equality in Sweden' also states that 'with a feminist government and a law against gender discrimination, how come Swedish board rooms are still heavily male-dominated?'.

Gender is not only discussed in the most obvious ways. For instance, out of four themes dedicated to fashion, one is explicitly labelled 'Fashion and Gender', highlighting norm-breaking brands with unisex design and portraying fashion as 'a starting point to explore new ways of expressing gender through their designs, pushing for a less binary and more fluid way of understanding masculinity, femininity and everything in-between' (Sweden. $s e$, n.d. c). Other highlighted features and headlines of the site include depictions of '10 Swedish Superwomen', many of whom are young women entrepreneurs in the entertainment industry. An image of footballer Lotta Schelin, rather than an image of, say, Zlatan Ibrahimovic, is used as the front image of the article 'Swedish Superstars in Sports'.

A systematic gender-mainstreaming effort is visible in many of the themes on the website. Gender equality appears in one out of five themes covered on the site (31 of 159). For example, the theme 'How To Start Up the Swedish Way' features stories from three women and three men, zipper-wise (first a woman, second a man, third a woman, fourth a man, etc.). An article entitled '5 Reasons to Work in Sweden' emphasizes the rights enjoyed by workers, with equality (including anti-discrimination and gender-equality provisions) as a second reason, and family-centred policies as a third. In 'Fashion as an Experiment', which lists brands that stand out, female designers dominate. In the several 'best of' rankings provided on Sweden. $s e$, men and women are equally represented. For example, the article ' 10 Must-Read Swedish Books' includes presentations of four books authored by women and six by men. Swedish film facts highlighting famous Swedish actors, genres and directors feature five females and seven males. This appears to be a systematic effort.

As in Denmark, Finland and Iceland, a number of stories highlight how Sweden was the 'first' to take various steps, underscoring the preferred Nordic image as avant-garde. In various places on the site, one can learn that Sweden was the first country in the world to allow for the legal change of 
gender identity (1972), the first to replace maternity leave with parental leave (1974), the first to create a ban on spanking children (1979), the first to pass a law to prohibit the purchase but not sale of sexual services (1999), and so on. As we shall see, the Finnish brand, analysed next, has not integrated gender equality to anything like the same degree as Sweden, even if the role-model claims are just as strong.

\section{Functional Finland}

The national brand of Finland was not fully launched until 2013, even though the process of developing a brand platform began in 2007, when the MFA and the Tourism Board of Finland hired consultants to draft a branding plan. Moilanen (2016) has described this process well. The branding plan emphasized the need to involve broad sectors of society as stakeholders and to ensure commitment to the brand from central political, business, cultural and sports actors. Until 2011, the work to develop the brand was quite ambitious, involving a high-level Country Brand Delegation (made up of 22 prominent Finns with varied backgrounds, including business, academia, culture and the arts, media, politics, public administration and sports), the consultancy of premier brand entrepreneur Simon Anholt, who has also been involved in the development of the Swedish brand, and outreach activities involving society at large (Moilanen, 2016). The delegation submitted its final report in 2010, entitled Mission for Finland.

The 2011 elections, which involved a change of government, led to eroded support for the ongoing branding initiative (Moilanen, 2016). Branding efforts were now moved to a new 'Team Finland' network, which was established in 2011 with massive private-sector interest, to develop Finland's external economic relations and financial interests. Team Finland was not a new organization with its own budget and dedicated staff - it was instead a network among existing agencies and organizations. It is steered by the prime minister, with the Ministry of Employment and the Economy, the Ministry for Foreign Affairs, and the Ministry of Education and Culture at the centre of the network, and it involves Finnish diplomatic and other offices abroad. The board of Team Finland, which is chaired by the prime minister, is almost exclusively made up of private-sector directors, a dramatic break from the earlier attempts to involve broad sectors of society. In 2013, the Unit for Public Diplomacy of the Ministry for Foreign Affairs, with the help of US strategic communications agency Kreab Gavin Anderson, published the Finland Country Image Communications Workbook, to be used by all Team Finland participants and other interested parties (Ministry for Foreign Affairs, Finland, 2013).

Also in 2013, the Finland Promotion Board was formally brought into Team Finland and tasked with defining, coordinating and implementing the national brand strategy. The Finland Promotion Board is made up of marketing and communications professionals, and the board is chaired by 
the prime minister. The Finland Promotion Board maintains Finland's official country brand website at Finland. $f$, which is called ThisisFINLAND (produced by the Ministry for Foreign Affairs of Finland). The website was originally established in 1995 and changed its name to ThisisFINLAND in 2009. In 2017, the Finland Promotion Board published Finland's Country Branding Strategy 2017, a brief document that built on Finland's earlier country brand strategy. Despite its brief five years of existence, the Finnish brand platform - pivoting around the concept of 'functional Finland' - is quite coherent and well established.

Turning to our analysis of Finland. $f$, the Finnish brand is clear and concise and has consistently centred on Finland as a highly 'functional' society. Three interrelated themes are central to the 2017 brand platform: 'Education and Knowledge', 'Nature' and 'Solution Oriented' (Finland Promotion Board, 2017). The brand message on Finland. $f i$ is indeed one of a nation of active, nature-loving and solution-oriented people who are products of one of the world's best education systems. Finns, we learn, value equality and environmentally sustainable technology and solutions. Because of its excellent, egalitarian public education system, this is a nation poised to find innovative and sustainable solutions to virtually any problem. Finland, the site conveys, is a place where things work and people are happy (in fact, the happiest in the world according to the featured European Happiness Equality Index). In short, Finland is branded as a highly functional place.

Before we turn to the issue of gender, we might note that there is not the same explicit emphasis on Finland as a homogeneous national community that we find in relation to Denmark on Denmark.dk. The Swedish-speaking and Sami minorities of Finland are present, and there is brief mention of multiculturalism and even racism in Finland. ${ }^{9}$ Visually, people of colour appear here and there in the photos on the site, giving the visual impression of an almost but not entirely white society. A discussion of Nasima Razmyar, deputy mayor of Helsinki and former member of parliament for the Social Democrats, begins by describing her as an Afghanistan-born woman 'living as a Finn in Finland'. What does 'living as a Finn' entail? Focus is placed on her work for women's rights, which - along with her successful political career -is attributed to Finland's 'legacy' of gender equality (Finland.fi, n.d. b).

The place of gender equality in the Functional Finland brand is paradoxical. On the one hand, Finland.fi does not rely extensively on gender equality, at least not textually. Of the hundreds of articles that appear on the Finland site, only around ten are expressly about gender equality (tagged 'gender' or 'equality') and they are not centrally placed. A few more mention equality between the sexes (Finland.fi, n.d. c). And yet when gender equality is discussed, the discussion is anything but modest. On Finland.fi, Finland is consistently depicted as a gender-equality leader, both in terms of present conditions and in terms of leading the way historically. No less than four articles concern an international gender-equality prize that the government of Finland launched in 2017. The prize serves to set up Finland as a 
gender-equality authority, with Finland as a place that knows gender equality and is qualified to promote it elsewhere: 'Finland has been a leader when it comes to issues relating to gender equality over the past 100 years, and this is the first high-profile prize of its kind in the world,' declares a quotation from the state secretary at the Prime Minister's Office. Indeed, the express function of the prize is to 'cement Finland's role as leader in gender equality issues' (Finland.fi, n.d. d). A similar prize was established in 2019 to recognize the promotion of LGBTQ inclusivity. The prize is named 'Hän Honor' after the new, gender-neutral pronoun 'hän' (Finland.fi, n.d. e).

Finland's historically pioneering role on women's rights is also emphasized. Readers learn that, in 1906, the Finnish parliament was the first in the world to recognize women's right to run for office and the first in Europe to recognize women's suffrage (Finland.fi, n.d. f). Lively portraits of the accomplishments of historical women's rights activists in Finland are presented, along with information about how they are celebrated in contemporary Finland. For instance, Finnish flags are flown on 1 October each year to commemorate Miina Sillanpää, an activist and one of the first women elected to the Finnish parliament (Finland.fi, n.d. g), and 17 March is Minna Canth Day, to celebrate the nineteenth-century author and women's rights activist. As in the Swedish brand, there is little if any emphasis on contemporary resistance to gender equality in Finland, such as among supporters of the radical right populist party True Finns.

As in the Danish case, there is a range of obvious opportunities for highlighting gender equality that are not seized. For instance, to express what is unique about Finland and the Nordic region, one article features the reflections of a Finn in the USA on life as a professional in the two countries (Finland.fi, n.d. h). Finland's public funding of daycare, education and healthcare for all is compared with costs in the USA. This comparison could very easily have been presented in gender-equality terms: given existing gender roles with respect to children and the family, public daycare is crucial for enabling women in particular to combine work and parenthood. Instead, the professional in question is a man whose main worry is the bottom line - how much all these things cost. It would indeed have been simple to highlight the gender-equality implications of the differing systems, but this is not done. Another article, with the title 'Smart People Build Smart Machines in Finland', emphasizes how people from Turkey and China come to Finland to learn and build things. Women are notably absent from this story, however, as the images and people in the article are only men. The reproduction of the connection between being smart, science and masculinity is quite stark in the article. This could have been an opportunity to break up such a stereotypical connection and instead showcase women in science (Finland. $f i$, n.d. i). There are numerous other instances of stereotypical depictions of men, including an article on the accessibility of Finnish nature entitled 'Into the Finnish Wild', which features a muscular man, rather than a woman, riding a mountain bike (Finland.fi, n.d. j). The contrast with Swedish efforts 
to use every opportunity to present women and men in non-stereotypical gender roles and settings is striking.

\section{Inspirational Iceland}

Conscious efforts to manage Iceland's international reputation can be traced to the 'Iceland Naturally' marketing programme that was launched in North America in 1999 by the New York offices of the Icelandic Tourism Board and the Ministry of Foreign Affairs' Overseas Business Services to serve Icelandic tourism and business interests (Pálsdóttir, 2008). The programme is still running. In 2006, it was expanded to Europe. In the same year, the Icelandic government hired a specialist and commissioned a more systematic report on Iceland's image. The next step in developing the Icelandic national brand took place in 2010, with a new campaign 'Inspired by Iceland'. This was launched after the volcanic eruption that caused massive air-traffic disruptions in Europe (Benediktsson et al., 2011) and relies on extensive collaborations between the government of Iceland, the city of Reykjavík and tourism-related companies. A new website was set up, ${ }^{10}$ mainly dedicated to attracting tourists. The Icelandic parliament passed a Promote Iceland Act in 2010, founding an agency specifically dedicated to strengthening Iceland's image and reputation. Promote Iceland is a public-private partnership managed by an executive board consisting of four members from the private sector and three appointed by the government. It runs the official country website, Iceland.is, and its most recent country document, simply called 'Iceland Brochure', comes from 2016 and is a slight reformulation of previous versions.

The official gateway to Iceland, Iceland.is, conveys a message of Iceland as a progressive, modern society, ranking at the top of measurements for quality of life. The story it tells is of a country characterized by harsh nature and isolation, which produced a resilient people. Probably owing to the country's heavy dependence on the tourism industry, both the website and the country brochure are dominated by beautiful nature shots, and some pages are devoid of any text (Promote Iceland, 2016).

Gender equality is not heavily present on the website, and information about gender relations in Iceland is not easy to find. The term 'gender equality' only gives four hits in the website's search engine. However, the two occasion-specific articles that draw attention to the 'Centenary of Icelandic Independence and Sovereignty' (2018) and 'Anniversaries of Equality' (2015) highlight Iceland as being highly progressive with regard to gender equality, even a 'frontrunner in gender equality'. They describe Icelandic women's path towards gender equality in detail:

Iceland has topped the Gender Gap Index for nine years in a row... recent revolutions [have contributed] such as Free the Nipple against 
online gender-based violence, the Reykjavik Slut Walk where people marched against sexual violence and returned the shame to the perpetrators and the international \#metoo movement.

(Iceland.is, n.d. a)

These descriptions provide an interesting contrast to the Swedish narrative about gender equality, where the feminist struggle is mostly written out of the story. The Icelandic brand stresses 'fight', 'revolutions' and 'marches', all highly contentious repertoires of the feminist movement (see also Erlingsdóttir, this volume). Gender equality is thus represented as a matter of ongoing competing interests rather than as a cultural trait that is characteristic of the Icelandic population as a whole as a result of developments in a historical past.

While the slogan for the Iceland Brochure and the website is 'Come and be inspired by Iceland', gender equality is not something utilized for inspirational purposes. The page in the brochure specifically named 'Iceland as Inspiration' lists Icelandic culture - for example, music, narrative poetry, writers and performance art, along with a 'well educated population with one of the most extensive literacy rates in the world' - and 'commitment to sustainability'. Notably, gender equality is not mentioned. This matches the very scarce information on the website dedicated to gender equality, which is buried in occasional notes. Iceland undoubtedly has a lot to boast about when it comes to gender-equality achievements, and yet this is rarely done. When it is, gender-equality 'firsts' are emphasized, much as in the other national brands. For instance, we learn that Iceland had the first democratically elected woman president in the world (1980) and the first openly gay prime minister in the world (2009).

This last fact does not lead to LGBTQ rights being prominently featured on the website, however. Yet again, when we do find a relevant article, this time called 'Rights of the Individual', there is a lot of substantial information evidencing Iceland's achievements. The article tells a story of Iceland as 'the oldest parliamentary democracy in the world'; however, 'despite old traditions, the Icelandic political mentality is progressive with the country repeatedly receiving top ranking in studies measuring political freedom, gender equality, and human development' (Iceland.is, n.d. b). The evidence of this progressive mentality brought up later in the text is: gender equality, with the country having 'topped the World Economic Forum's Global Gender Gap Report in recent years'; LGBTQ rights; and being 'the most peaceful nation in the world according to the Global Peace Index'. In sum, the branding website Iceland.is does present the country as having many achievements with regard to gender equality, and also specifies that Icelandic society reached this point through feminist struggle. However, the information about these achievements does not figure prominently on the website and is not well integrated in the visual and textual representation of the country. 


\section{Conclusion}

Although the brands of the Nordic states are not equally coherent and clear, they all rest on a similar foundation and highlight traits that are in line with the broader national narratives of the individual Nordic countries. All five brands highlight egalitarian and welfare-providing institutions, modern and secular values, nature-loving peoples, and environmentally and hi-tech-oriented economies. None of these branding sites relies on images or narratives that objectify and sexualize women (see Jezierska and Towns, 2018), the kind of branding that has been documented in Canada and Japan, for instance (Miller, 2011; Rankin, 2012). All of the sites utilize images that represent men and women in various roles - as parents, workers, innovators, and so on. This tells us not only that gender equality is key to Nordic national identities, but also that branding, to be regarded as successful, must be in line with the self-images and the policies pursued by the individual countries of the Nordic region. The images of nature include both men and women as active explorers: there is little trace of representations of empty swaths of land subjected to the male gaze, which Loftsdóttir (2015) claims characterized previous Icelandic nation-branding campaigns. None of the brands displays overt gender inequality, and all of them make an effort to include men and women more or less equally in the visual representations. That said, the degree to and way in which gender equality is highlighted varies quite drastically.

Still, it is surprising how different the branding of gender equality is on the country websites. Whereas the Swedish online brand has incorporated gender equality throughout the country's website, neither Denmark. $d k$ nor Norway's sites make much effort to brand gender equality or women's rights as part of what is Danish or Norwegian. Finland and Iceland do so to a greater extent, but neither has integrated gender-equality messages into the entirety of the national narrative in the way that Sweden has. Interestingly, wherever Finland and Iceland do address gender equality, they do so forcefully. Both claim to be 'first' on a number of gender-related accomplishments, and both present themselves as international leaders or role models on gender equality. Given the boldness of these claims, it is a bit curious that the gender-equality dimension is not emphasized more prominently in the Finnish and Icelandic brands. In the light of the above, it is evident that the suggestion of the Nordic Council of Ministers that each Nordic country promote gender equality has yet to come to fruition online.

In the competitive field of nation-branding in the international arena, the Nordic countries play a mixed game. On the one hand, they appear as team players. There is surprisingly little comparison or explicit competition between the Nordics in the analysed documents and websites. Even when claiming firstness in various gender-related rankings, this is not done in contrast to other Nordic competitors. Such a move contributes to the fact that, especially from a distance, the Nordics appear as a group of like-minded countries, which all share commitment to gender equality 
as a fundamental element of their respective national identities. There is a risk that the nation brands become indistinguishable, however. Thus, on the other hand, a more subtle competition between the Nordics also takes place. As evidenced above, their nation brands feature gender equality to a varying degree, positioning them differently in the international nation-branding game. Here, the simultaneous challenge is not to appear as self-righteous in the quest for moral status, as that would usurp the moral superiority crown. This concern might explain the different choices the countries have made regarding how explicit and vocal they are about their gender-equality achievements.

\section{Notes}

1 See https://denmark.dk, https://finland.fi/, https://www.iceland.is/ and https:// sweden.se/. Norway stands out as the only country that does not maintain an official country website. Instead, https://www.norway.no/ is used as the portal for the embassies and missions of the Norwegian Foreign Service, and multiple other sites serve to brand Norway. Most important of these is the travel guide at https://www.visitnorway.no/. Our analysis of Norwegian nation-branding is thus more limited than that of the other states.

2 Email correspondence with the Danish Ministry of Foreign Affairs, 25 October 2018.

3 This text is taken from the details found at the bottom of all pages of the website at denmark.dk (accessed December 2018).

4 The official website of the Norwegian government is located at www.regjeringen. no; an English-language version is available at www.government.no.

5 See https://www.norway.no.

6 See www.visitnorway.com.

7 See www.studyinnorway.no.

8 See https://www.innovasjonnorge.no.

9 See, for example, Finland.fi (n.d. a).

10 See https://www.visiticeland.com/ (accessed December 2018).

\section{References}

Angell SI and Mordhorst M (2015) National reputation management and the competition state: The cases of Denmark and Norway. Journal of Cultural Economy 8(2): 184-201.

Benediktsson K, Lund KA and Huijbens E (2011) Inspired by eruptions? Eyjafjallajökull and Icelandic tourism. Mobilities 6: 77-84.

Clerc L, Glover N and Jordan P (eds) (2015) Histories of Public Diplomacy and Nation Branding in the Nordic and Baltic Countries: Representing the Periphery. Leiden: Brill-Nijhoff.

Cremer J (2016) Why Denmark is suffering a branding crisis (and what can be done about it). The Local DK, 6 December. Available at: https://www.thelocal. $\mathrm{dk} / 20161206 /$ why-denmark-is-suffering-a-branding-crisis-and-what-can-bedone-about-it (accessed December 2018).

Csaba F and Stöber B (2011) 'Copenhagen is hot, Denmark is not.' On the authority and role of place brand image rankings. Creative Encounters Working Paper no. 52. Copenhagen: Copenhagen Business School. 
Denmark.dk (n.d. a) Why Denmark is a great place to live. Available at: https:// denmark.dk/people-and-culture (accessed December 2018).

Denmark.dk (n.d. b) Why are Danish people so happy? Available at: https://denmark. $\mathrm{dk} /$ people-and-culture/happiness (accessed December 2018).

Denmark.dk (n.d. c) Trust: A cornerstone of Danish culture. Available at: https:// denmark.dk/people-and-culture/trust (accessed December 2018).

Denmark.dk (n.d. d) Religion and identity. Available at: https://denmark.dk/ people-and-culture/religion (accessed December 2018).

Denmark. $d k$ (n.d. e) Income and gender equality in Denmark. Available at: https:// denmark.dk/society-and-business/equality (accessed December 2018).

Denmark.dk (n.d. f) Work-life balance. Available at: https://denmark.dk/societyand-business/work-life-balance (accessed December 2018).

Denmark.dk (n.d. g) Danish cinema throughout history. Available at: https:// denmark.dk/people-and-culture/film (accessed December 2018).

Denmark.dk(n.d.h)Denmarkand theworld.Availableat:https://denmark.dk/societyand-business/denmark-in-the-world (accessed December 2018).

Dinnie K (2008) Nation Branding: Concepts, Issues, Practice. Amsterdam: Elsevier.

Erlingsdóttir I (2021) Trouble in paradise? Icelandic gender-equality imaginaries, national rebranding and international reification. In: Larsen E, Moss SM and Skjelsbæk I (eds) Gender Equality and Nation-Branding in the Nordic Region. Abingdon: Routledge.

Finland.fi (n.d. a) Leaving our comfort zone. Available at: https://finland.fi/artsculture/leaving-our-comfort-zone/ (accessed December 2018).

Finland.fi (n.d. b) Living as a Finn in Finland. Available at: https://finland.fi/lifesociety/living-as-a-finn-in-finland/ (accessed December 2018).

Finland. $f$ (n.d. c) A guide to Finnish customs and manners. Available at: https:// finland.fi/life-society/a-guide-to-finnish-customs-and-manners/ (accessed December 2018).

Finland. $f i$ (n.d. d) Finland launches International Gender Equality Prize. Available at: https://finland.fi/life-society/finland-launches-international-gender-equalityprize/ (accessed December 2018).

Finland.fi (n.d. e) Honouring inclusivity with Finnish pronoun power. Available at: https://finland.fi/life-society/honouring-inclusivity-with-finnish-pronoun-power/ (accessed December 2018).

Finland. $f i$ (n.d. f) Finland's Parliament: Pioneer of gender equality. Available at: https://finland.fi/life-society/finlands-parliament-pioneer-of-gender-equality/ (accessed December 2018).

Finland.fi (n.d. g) Real bridge-builder became Finland's first female government minister. Available at: https://finland.fi/life-society/real-bridge-builder-becamefinlands-first-female-government-minister/ (accessed December 2018).

Finland.fi (n.d. h) A Finn in America ponders the luxury of enjoying life. Available at: https://finland.fi/life-society/a-finn-in-america-ponders-the-luxury-ofenjoying-life/ (accessed December 2018).

Finland.fi (n.d. i) Smart people build smart machines in Finland. Available at: See https://finland.fi/business-innovation/smart-people-build-smart-machines-infinland/ (accessed December 2018).

Finland. $f$ (n.d. j) Into the Finish wild. Available at: https://finland.fi/life-society/ into-the-wild/ (accessed December 2018). 
Finland Promotion Board (2017) Finland's country branding strategy. Available at: https://toolbox.finland.fi/strategy-research/finlands-country-branding-strategy/ (accessed December 2018).

Försäkringskassan (2018) Mammor tar ut största andelen av föräldrapenningen. 24 May. Available at: https://www.forsakringskassan.se/!ut/p/z0/LckxCsMwD EDRs3TwKOzSrVtuEbIUEauJiS0ZSXWu3xQ6fR4_LnGOC-MoG3oRxnp5Pt f27Oh7uD-mkFZhJ3aj15J1YSuDQuoX7J9GOVNFzsQhNWxNFBwVPg7mouY Iv1mJAQe8RbFmxU7MhbfYj-n2BU1YQyo!/ (accessed December 2018).

Government.no (2013) Norway's image abroad: A shared responsibility. Last updated 9 January 2013. Available at: https://www.regjeringen.no/en/topics/ foreign-affairs/int-cultural-engagement/norgesprofilering/image_abroad/ id708753/ (accessed December 2018).

Government.no (2015) The Ministry's public diplomacy work. Last updated 30 April 2015. Available at: https://www.regjeringen.no/en/topics/foreign-affairs/intcultural-engagement/norgesprofilering/slik-jobber-ud-med-norgesprofilering/ id2001887/ (accessed December 2018).

Iceland.is (n.d. a) Centenary of Icelandic independence and sovereignty. Available at: https://www.iceland.is/press/press--media-kit/centenary-of-icelandicindependence-and-sovereignty (accessed December 2018).

Iceland.is (n.d. b) Rights of the individual. Available at: https://www.iceland.is/thebig-picture/news/political-freedom/11592 (accessed December 2018).

Jezierska K and Towns A (2018) Taming feminism? The place of gender equality in the 'Progressive Sweden' brand. Place Branding and Public Diplomacy 14(1): $55-63$.

Larsen E (2021) 'The gender-progressive Nordics': A matter of history. In: Larsen E, Moss SM and Skjelsbæk I (eds) Gender Equality and Nation-Branding in the Nordic Region. Abingdon: Routledge, 13-38.

Lending M (2000) Oppbrudd og fornyelse. Norsk utenrikskulturell politikk 20012005. 27 January. Available at: http://www.regjeringen.no/nb/dep/ud/dok/ rapporter_planer/rapporter/2000/Oppbrudd-og-fornyelse.html?id=105583 (accessed December 2018).

Leonard M and Small A (2003) Norway's Public Diplomacy: A Strategy. Available at: https://www.regjeringen.no/globalassets/upload/UD/Vedlegg/public.pdf (accessed December 2018).

Loftsdóttir K (2015) The exotic north: Gender, nation branding and postcolonialism in Iceland. NORA: Nordic Journal of Feminist and Gender Research 23(4): 246-260.

Marklund C (2017) The Nordic model on the global market of ideas: The welfare state as Scandinavia's best brand. Geopolitics 22(3): 623-639.

Merkelsen H and Rasmussen RK (2015) The construction of Brand Denmark: A case study of the reversed causality in nation brand valuation. Valuation Studies 3(2): 181-198.

Miller L (2011) Cute masquerade and the pimping of Japan. International Journal of Japanese Sociology 20(1): 18-29.

Ministry for Foreign Affairs, Finland (2013) Finland Country Image Communications Workbook. Helsinki: Ministry for Foreign Affairs.

Moilanen T (2016) Case: A road map for Finland's nation branding. In: Dinnie K (ed.) Nation Branding: Concepts, Issues, Practice. London: Routledge, 256-260. 
Mordhorst M (2015) Public diplomacy vs nation branding: The case of Denmark after the cartoon crisis. In: Clerc L, Glover N and Jordan P (eds) Histories of Public Diplomacy and Nation Branding in the Nordic and Baltic Countries: Representing the Periphery. Leiden: Brill-Nijhoff, 237-256.

Nämnden för Sverigefrämjande i utlandet (NSU) (2009) Progressiv kommunikation $i$ praktiken. Available at: https://si.se/wp-content/uploads/2012/12/Progressivkommunikation-i-praktiken.pdf (accessed December 2018).

Nämnden för Sverigefrämjande i utlandet (NSU) (2014a) Sverigebildsstrategi. PDF from Power Point presentation. Available at: http://sharingsweden.se/wp-content/ uploads/2015/06/Sverigebildstrateginkort-Sweden-Sans-3.pdf (accessed December 2018).

Nämnden för Sverigefrämjande i utlandet (NSU) (2014b) Strategi för arbetet med Sverigebilden $i$ utlandet (shorter version). Available at: http://sharingsweden.se/ wp-content/uploads/2015/06/Sverigefoldernsvenska-i-A5-format.pdf (accessed December 2018). The shorter version is also available in English at: http:// sharingsweden.se/wp-content/uploads/2015/06/Sverigefoldern-engelska-i-A5format.pdf (accessed December 2018).

Nämnden för Sverigefrämjande i utlandet (NSU) (2017) 2.0 Strategi för arbetet med Sverigebilden $i$ utlandet - en vägledning. Available at: http://sharingsweden.se/ wp-content/uploads/2017/04/Strategi-2.0-f\%C3\%B6r-arbetet-med-Sverigebildeni-utlandet.pdf (accessed December 2018).

Nordic Council of Ministers (2015) Strategy of International Branding of the Nordic Region 2015-2018. Copenhagen: Nordic Council of Ministers.

Omdømmesutvalget (2006) Omdømmesutvalgets slutrapport. Available at: https:// www.regjeringen.no/globalassets/upload/kilde/ud/bro/2006/0049/ddd/pdfv 1275674-nyskapende_i_samspill_internett.pdf (accessed 8 July 2020).

Pamment J (2013) New Public Diplomacy in the 21st Century: A Comparative Study of Policy and Practice. London: Routledge.

Pálsdóttir IH (2008) Country case insight - Iceland. The case of 'Iceland naturally' - Establishing an umbrella brand to increase country image impact and coherence. In Dinnie K (ed.) Nation Branding: Concepts, Issues, Practice. Amsterdam: Elsevier, 183-186.

Promote Iceland (2016) Iceland brochure. Available at: https://www.islandsstofa.is/ media/1/landkynningarbaekl-english-2016.pdf (accessed December 2018).

Rankin PL (2012) Gender and nation branding in 'the true North strong and free'. Place Branding and Public Diplomacy 8(4): 257-267.

Red Associates (2006) Denmark ${ }^{\mathrm{TM}}$ : Perceptional Analysis and Recommendations for an Aggressive Global Marketing of Denmark. Copenhagen: Red Associates.

Study in Norway (n.d.) Norwegian society. Available at: https://www.studyinnorway. no/living-in-norway/norwegian-society (accessed December 2018).

Sweden.se (n.d. a) Gender equality in Sweden. Available at: https://sweden.se/ society/gender-equality-in-sweden/ (accessed December 2018).

Sweden.se (n.d. b) Gender equality in Sweden. Available at: https://sweden.se/ society/sweden-gender-equality/ (accessed December 2018).

Sweden.se (n.d. c) Fashion and gender. Available at: https://sweden.se/collection/ swedish-fashion/article/fashion-and-gender/ (accessed December 2018 but is no longer available).

Swedish Institute (n.d.) Our mission. Available at: https://si.se/en/about-si/ourmission/ (accessed December 2018). 
Swedish Institute (2007) Sverigebilden. Stockholm: Swedish Institute.

Swedish Institute (2008) Sverigebilden 2.0. Available at: https://si.se/wp-content/ uploads/2012/12/Sverigebilden-2.0.pdf (accessed December 2018). Also available in English at: https://paprikash.files.wordpress.com/2009/03/brand-sweden.pdf (accessed December 2018).

Synovate (2009) Improving Norway's Reputation. Available at: http://www.regjeringen. no/upload/UD/Vedlegg/Kultur $\% 20$ og $\% 20$ profilering/Omdoemme/Synovate $\% 20$ -\%20Improving $\% 20$ Norway $\% 27 \mathrm{~s} \% 20$ Reputation $\% 20$ FINAL $\% 20$ PRINTED.pdf (accessed December 2018).

Teslik LH (2007) Nation branding explained. Foreign Affairs, 9 November.

Visitnorway.com (n.d. a) Stories. Available at: https://www.visitnorway.com/stories/ (accessed December 2018).

Visitnorway.com (n.d. b) Womens museum. Available at: https://www.visitnorway. com/listings/womens-museum/11164/ (accessed December 2018).

Visitnorway.com (n.d. c) LGBTQ+ travel. Available at: https://www.visitnorway. com/plan-your-trip/travel-tips-a-z/lgbt-travel/ (accessed December 2018).

Visitnorway.com (n.d. d) The happiest country on Earth. Available at: https://www. visitnorway.com/media/news-from-norway/the-happiest-country-on-earth/ (accessed December 2018).

Visitsweden.com (n.d. a) LGBT+ Sweden. Available at: https://visitsweden.com/ what-to-do/lgbtq/gay-and-lesbian/ (accessed December 2018).

Visitsweden.com (n.d. b) LGBT+ travel inspiration. Available at: http://visitsweden. lgbt/ (accessed December 2018). 


\title{
3 Applying the brand or not? Challenges of Nordicity and gender equality in Scandinavian diplomacy
}

\author{
Sigrun Marie Moss
}

The Nordic brand has experienced a great upsurge over the last 20 years within a range of areas that include design, cuisine, welfare and the focus of this book - gender equality. Nordic countries are often seen as 'superpowers' of gender equality, and the Nordic model of gender equality has been discussed and emphasized by many (see, for example, Melby et al., 2009). A quick search on the website of the New York Times for the terms 'Nordic' and 'gender equality' yields headlines such as 'Nordic Gender Gap Is Thinner' (New York Times, 2005) and 'Nordic Nations Remain GenderEquality Leaders' (Clark, 2010). Gender equality is a key image conjured when thinking about the Nordic region: 'In an international comparison, gender equality is probably among the features distinguishing the Nordic societies of today' (Lagerspetz, 2003: 57). The Nordic brand is seen as strong and successful (see Browning, 2007), and the brand thus entails clear advantages. However, different sides of this brand may also warrant exploring. Are there negative sides to the Nordic brand with regard to gender equality, and reasons to avoid using it?

Branding can be seen as a process that, among other things, 'differentiates the product from its competitors' (Davcik et al., 2015: 3). In Sweden, for example, the government has adopted a feminist foreign policy (see Solheim and Moss, 2020). This may serve to differentiate the Swedish Ministry of Foreign Affairs (MFA) from its counterparts in Denmark and Norway, whose governments have not taken an active feminist stance but are dedicated to working with gender equality. Van Ham $(2001,2008)$ argues that the branding of states and places is a key aspect of public diplomacy and the use of soft power. More specifically, he argues that 'the art of politics pursued through old-style diplomacy has been shifting to encompass the new art of brand building and reputation management' (Van Ham, 2008: 129), a development that closely ties foreign ministries to their countries' nationbranding activities (see also Angell and Mordhorst, 2015). Glover (2009), however, speaks of nation-branding as imaging communities rather than imagining nations (see also Jordan, 2015).

In branding efforts, whether it is communities, nations or something else that is to be branded, the notion of brand equity is central. This term refers

DOI: $10.4324 / 9781003017134-3$ 
both to the positive qualities of a brand and to its liabilities, which, in turn, either increase or decrease favourability in reactions and responses to the brand. Brand equity is thus the overall value that a brand entails or creates (Bailey and Ball, 2006). Keller (1993: 8) speaks of customer-based brand equity, defining this as 'the differential effect of brand knowledge on consumer response to the marketing of the brand' - in other words, the image consumers have of the brand, the level of awareness they have of it, the degree of loyalty they have to it, and the strengths and weaknesses they associate with it. How, then, do such issues about brand creation and management relate to Nordic gender equality?

In this chapter, I explore how diplomats from Norway, Denmark and Sweden talk about the Nordic brand in relation to gender equality. As part of their everyday work, diplomats are tasked with managing and creating a national brand. They are operators of soft power. It is therefore particularly interesting and valuable to ask them how they manage gender equality in their everyday activities, and how the Nordic or country-specific brand is intertwined with this.

Gender equality is important to the identities and self-imaginaries of all the Nordic states. Towns (2002: 162), for example, states that 'Sweden, like the other Nordic countries, developed an identity as a gender-equal state'. Similarly, a Norwegian diplomat interviewed for the study presented in this chapter stated that 'gender is central to our state identity and sense of who we are as a people'. Ministries of foreign affairs are key actors in both nation-branding and reputation management (Angell and Mordhorst, 2015), and function as sites for handling regional and state identities (Towns, 2002). What positives and negatives do they emphasize about the Nordic brand? Why and when is it useful, and what rhetoric is there against branding gender equality as Nordic among the diplomats? The analysis that follows is based on semi-structured interviews with Scandinavian diplomats.

\section{The Nordic gender brand in action}

Browning (2007) notes that there have been increasing efforts to market and make use of the shared Nordic brand. As becomes clear from the diplomats' accounts presented below, however, there are sometimes conflicting views about what the content of such a Nordic brand might be. The Nordic countries may go about this Nordic brand differently, both in general (Hansen and Wæver, 2002) and also specifically in relation to gender equality (see Larsen, this volume; Jezierska and Towns, this volume). Nevertheless, as Browning (2007: 30) argues,

aside from these various and sometimes divergent narratives, the Nordic countries have collectively and rather deliberately tried to construct and market a singular 'Nordic brand', a particular common 'Nordic experience' or way of doing things that is also presented as applicable for others. 
Magnus (2016) agrees that the Nordic brand is a brand, since the world already refers to the Nordic region as a brand. He does ask, however, whether 'five countries and three autonomous territories really [can] be bundled together under a common brand'. Both inside and outside the Nordic region, images of the region vary extensively, and Magnus therefore discusses the challenges posed by grouping together a 'number of nations under a common branding identity'.

The internal divisions become visible in the analysis presented below, and, as other chapters in this volume demonstrate, there is extensive variation in how the Nordic countries engage in branding (see, for example, Larsen, this volume; Jezierska and Towns, this volume; Skjelsbæk and Tryggestad, this volume). Further, the Scandinavian diplomats interviewed for this study approach the question of to how to utilize or avoid the Nordic brand in different ways. How, then, do the diplomats handle the Nordic brand in their work with gender equality? Do they emphasize the assets or the liabilities of the Nordic brand's links with gender equality?

The data material for this chapter consists of semi-structured interviews with diplomats from Denmark, Norway and Sweden in the period 2018-2020, conducted as part of the University of Oslo's Nordic branding project. The diplomats were recruited either by directly reaching out to focal points on gender equality in the foreign ministries of the three countries or by asking contacts for input. Snowballing was also used. Three - often interrelated work focuses were used to identify diplomats that would be asked to participate in the interviews: if a diplomat worked specifically (but not necessarily only) with gender; if they worked with branding and communication; and, for Sweden and Norway, if they were involved in those countries' campaigns for membership of the UN Security Council. ${ }^{1}$ The interviews were mainly carried out at the ministries in the three capitals, but some were also conducted at embassies/consulates in three locations outside Europe. Interviews were mainly done one on one, but at times two or three diplomats were interviewed at the same time. A few people were interviewed twice or more. I conducted 23 interviews with Scandinavian diplomats (Norway, 11 interviews, 11 different people; Denmark, 5 interviews, 6 people; Sweden, 7 interviews, 8 people). The sample consisted of both senior diplomats in higher office and more junior diplomats. I also conducted 8 interviews with other individuals (local staff at embassies, 5; a representative from the Nordic Council of Ministers, 1; representatives of other ministries, 2). Of the 34 people in the sample, there were 27 female and 7 male participants. ${ }^{2}$

The interviews commonly lasted around 60 minutes. Only a few of the interviews were recorded; for the rest, I relied on extensive notes, helped by a coding system that enabled me to get the majority of the sentences down word for word (when I compared the recorded interviews with my notes for those interviews, I found that I had captured about $80 \%$ of the words used). To establish rapport, all respondents were informed that they would be given the transcript of their interviews to edit as they saw fit. This was 
important, as I believe much of the information shared would not have been shared without this measure. The editing varied from relatively minimal changes, to corrections on factual points, to editing out whole issues. While this 'cost' me material, it also allowed for greater awareness of which issues were considered particularly sensitive, which proved very useful in further interviews, as I was able to ask specifically about issues I might otherwise not have known about.

When asked about the Nordic brand in relation to their work with gender equality, participants emphasized both advantages and disadvantages with the brand. Wanting to focus on these positive and negative sides to the Nordic brand, I analysed the material, looking for how the diplomats were positioning the brand and the imaginaries of the Nordic brand related to gender equality, and from these readings I constructed four themes. The first focused on links between the Nordic brand and ideas of moral superiority; the second focused on the Nordic brand as an old-fashioned approach to increasing gender equality; the third discussed internal differences that lead to a competitive emphasis on national brands rather than the regional Nordic brand; and, lastly, the fourth examined the expectations regarding the use of the Nordic brand for lobbying and collaboration across the region. What becomes clear from the nature of these four themes is that the need for caution when handling the Nordic brand was emphasized more by respondents than the positive aspects of the Nordic brand. The two first themes refer to negative aspects of the brand, the third to internal competition, and only the last directly to positive aspects of the brand.

It should also be added that in the interviews with the Swedish and Danish representatives, I became Norway. As a Norwegian, I was frequently positioned as a country representative, rather than being a more 'neutrally placed' researcher. This was demonstrated time and again in the interviews: 'We have a long tradition of working with gender equality. As you do in Norway' (Swedish diplomat), and 'We are good at the Women, Peace and Security agenda. But you are of course also very strong when it comes to that' (Danish diplomat).

\section{Balancing perceptions of moral superiority}

In the interviews, it was made clear that the Nordic brand can carry elements of moral superiority, with the Nordics telling the world how things should be done. This narrative of moral superiority has been problematized (see, for example, Liinason, 2018; and, in relation to Sweden, Towns, 2002) and has been coupled with the Nordic exceptionalism narrative (see Rastas, 2012).

All the participants brought up the problematic moral superiority associated with the Nordic brand. A senior Norwegian diplomat declared: 'The Nordic brand comes with a real danger of being seen as superior and knowit-all.' Here the diplomat made it clear that her ministry wanted to avoid 
the imaging this entailed. One Norwegian diplomat working especially with gender equality commented that the Nordic brand risked evoking moral superiority, making it beneficial to instead brand the ministry's gender focus as Norwegian, as she explained that the moral superiority was much more explicitly tied to the Nordic overarching brand than to the Norwegian. This was echoed in other interviews with Norwegian diplomats, as well as in those with Danish and Swedish diplomats. There was thus the impression that moral superiority was seen as more of a challenge with the regional rather than the country-specific brands (even though there may very well also be elements of moral superiority linked to these). A Danish diplomat disagreed, however, and said that within her portfolio it was the Swedish rather than the Nordic brand that was seen as morally superior - a view with which she also agreed: 'And the Swedes do think they are a bit more important that way.' The diplomat further emphasized that the Nordic brand did not invoke the same connotations: 'I do not think that this Nordic aspect is that much of a problem within my area of work.'

To avoid the Nordic moral superiority stamp, the diplomats could instead choose to focus on their national brands. In presenting their individual country brands, the diplomats seemed mindful of the moral superiority label attached to the Nordic brand, and appear at times eager to emphasize that their national brands differ from that of the Nordic. One way of doing this could be through emphasizing their non-superiority on moral issues that is, by avoiding a 'glossy image' of the national brand. While acting as the Norwegian expert for a Nordic gender-equality seminar organized by the Nordic embassies in a non-European capital a few years ago, I was told several times by the Norwegian ambassador that I needed to give a nonutopian image of the gender-equality situation in Norway. It was emphasized that it was not constructive for the audience to hear too much about how good Norway is at working with gender equality, and that what was required was a more balanced version of events that also emphasized the challenges that remained.

A complicating factor here is the difference between internal attempts at branding and the external life of brands. To be meaningful, a brand needs to be seen as distinctive by others (Ringmar, 2002). An audience may associate specific approaches with the country brand or the regional brand independently of what the countries in question intended. 'Others can easily see us as the Nordics, even if we try to opt out of the brand', one Norwegian diplomat said. Trying to emphasize one's country instead of the regional belonging can thus be difficult, which speaks to Browning's (2007) point that brands cannot merely be proclaimed, as they depend on an audience.

\section{Downplaying the Nordic to achieve gender results}

Some of the diplomats quickly brought up the issue of results when discussing the Nordic brand. They emphasized that, pragmatically, their ministries have better push-through for actual projects - such as, for example, efforts 
to combat female genital mutilation, family planning initiatives or increased female participation in peace processes - if these gender initiatives come from countries that are less established in terms of gender equality. A Danish diplomat said that even though such collaborations take place, this area of teaming up with partners from regions with less support for gender equality was one with room for improvement from the Nordics:

I think we are trying to be creative in our alliance-building, because we do not have to convince those who already agree with us. It is the others we should get onboard. China, Russia and the MENA countries, they cannot be bothered to listen to moralizing talk. Speaking to them, there are some other things we need to grasp. There, we are not up to scratch, I would say. It requires extensive thought work and relation-building to get such new collaborative constellations [on gender equality] up and running.

There was agreement among the diplomats that such collaborations were important for achieving results. A diplomat working specifically with gender in the Norwegian MFA explained:

Talking about Nordic branding of gender issues to an external audience, this is a bit old-fashioned. The optics of it does not serve the purpose. We need to think: Does it strengthen or weaken the message that five white people are pushing this agenda? We need to measure the optics of this up against the relevance to the intended audience. It is often more powerful if the message is fronted by South Africa or Colombia rather than the Nordic countries.

It hardly comes as a surprise that the Nordic countries vote for and push for gender equality in international fora. This stance is expected, both by audiences within the Nordic countries themselves and by other countries. But it seems that some of the diplomats see it as more effective if initiatives on gender-equality measures come from other countries, potentially in collaboration with a Nordic country. 'The end result is often better then,' one Norwegian diplomat commented in relation to the increased international traction on gender equality in such a situation. She continued: 'The more of us from the Nordic countries there are when presenting gender-equality projects, the more detrimental to the results.' This was also backed up by other diplomats. A Norwegian diplomat said: 'It is often more powerful if the message is fronted by South Africa or Colombia rather than the Nordic countries.' Another Norwegian diplomat working with the UN explained in the interview:

It is important to emphasize that very often the message on gender equality can be more powerful when it comes from someone nonNordic. When it comes from someone in the Africa group or the Middle 
East group... this can have a greater impact and make the message reach further.

A senior Swedish diplomat offered a somewhat different take:

It is a core sentiment in diplomacy that we are stronger when we work together.... We clearly work actively to include countries in the global South, with whom we can go arm in arm so that we achieve greater plurality in the voices on this [gender equality]. It does not work well if only we up north talk about this.

These extracts may speak to different country-specific branding processes. On the one hand, some diplomats express the view that the best way to improve traction on gender equality is when other countries or organizations front gender-equality messages - where one's initiative is not tied to one's own country - which entails that one forgoes the branding opportunity presented by the initiative. Instead, the focus is on how a particular genderequality suggestion will have the most impact and thus the aim is to have someone else front the initiative, as we see in the above quotations from Norwegian diplomats. On the other hand, other participants comment that it is better to front such issues together with other countries that are not known as gender-equality forerunners, and to go arm in arm with these, as in the example from the Swedish diplomat. Another Swedish diplomat echoed this arm-in-arm stance:

It is not beneficial that the five of us Nordic countries stand side by side fronting something. Often the cause in question is better served by a different type of presentation. Certain questions should absolutely not be driven as Nordic questions. That can backfire. Then it can seem we think of ourselves as having all the answers. Now it has to be crossregional. Anti-terrorism for example, is something we front together with Jordan and South Africa.

Even if the diplomat is here using anti-terrorism as an example, rather than gender equality, the element of fronting something together with, rather than through, other nations is evident again. Here, nation-branding is not set aside but instead emphasized, with Sweden taking the lead in particular forms of collaborations. These two approaches potentially speak to differences in branding: The first (here represented by the Norwegian diplomat's extract) emphasizes the gender-equality results over the brand, and, here, diplomats are willing to forgo branding opportunities involved in linking the initiatives to their own countries. The second focuses both on the results and on the brand, as when the Swedish diplomats advocate for partnering with another country in fronting issues. Such differences in approaches to branding are seen across the interviews with all the diplomats and are also 
visible in other nation-branding activities (see Jezierska and Towns, this volume), with the starkest difference perhaps between Norway and Sweden. In both of the examples discussed above, however, there is agreement that branding gender equality as something Nordic can have negative effects, as shown in the Swedish quote: 'It does not work well if only we up north talk about this.' A Norwegian diplomat working with the UN said that there are many settings in which Norway would try to brand gender specifically as something universal rather than Nordic or Norwegian. In line with this reasoning, gender equality has its clear limitations in nation-branding processes, and the Nordic brand is one that needs to be handled with care if it is not to be detrimental to the cause.

\section{Internal Nordic differences and competition}

In the interviews, the diplomats speak about different priorities when it comes to gender-equality work. These differences in priorities can lead to country-specific rather than Nordic approaches to gender-equality work. One example of this came up in an interview with Danish diplomats: 'When we front the sexual and reproductive health and rights agenda, we have often stood alone, without getting strong support from the other Nordics.' The respondent here seems to express a sense of disappointment with the Nordic neighbours on this particular issue. In the interviews with Norwegian diplomats, however, one explanation for this lack of support came to the fore.

During several interviews with Norwegian diplomats, it was indicated that gender may be one of the areas in which the Nordic countries compete. Sweden has an explicitly feminist foreign policy and habitually portrays itself as being at the very forefront of the fight for gender equality: 'In Sweden, we have come far by international comparison; in fact, we have come the farthest in the world. We gladly share our experiences, we readily export our Swedish model for gender equality. ${ }^{3}$ Several of the other diplomats agreed that the Swedes are the strongest when it comes to gender. A Danish diplomat, for example, commented that 'of the Nordic countries, the Swedes are best at gender'. However, in interviews with diplomats from the other two countries, there is at times a tendency towards frustration with the fact that the Swedes want to 'go it alone'. A junior Norwegian diplomat observed that 'the Swedes see gender equality as their thing, with their feminist foreign policy and their strong focus on this. That can challenge the Nordic cooperation at times.' This may be a motivation to focus less on the Nordic brand per se, and may make the brand difficult to use. One Norwegian diplomat involved in peace and reconciliation stated that 'the Nordic cooperation is difficult.... It is challenging to have real Nordic cooperation on this. The result is then that everyone does their own thing.' A Danish diplomat posted at a non-European embassy commented that the Swedes are very focused on gender, while the Danes are 'more pragmatic when it comes to gender issues'. Such differences in focus, according to this diplomat, could make 
the shared Nordic brand more uncertain, as the contents of the brand are not synchronized across the Nordic or Scandinavian countries. The Swedes may place gender equality more centrally in their brand and therefore wish to focus on their national brand over the regional brand (see also Skjelsbæk and Tryggestad's chapter in this volume). For example, in a 111-page handbook on Sweden's feminist foreign policy (Ministry for Foreign Affairs, Sweden, 2019), the Nordic is only mentioned seven times. Distinctiveness - a key factor in branding - is established along the lines of the national identity, not the regional one.

\section{Together the Nordics can make the message count}

Some of the participants expressed the view that the Nordic regional brand did have potential for furthering work on gender equality and that it was useful especially when fronting particular topics, such as showcasing how societal structures that allow for extensive female participation in the workforce have extensive economic benefits. A senior Norwegian diplomat commented that the Nordic brand and Nordic cooperation on gender-equality issues could play a key role in certain advocacy and public relations issues in cases where there is strength in numbers, before going on to say add: 'It is useful to share experiences, but it should also be more than a talking club.' The same point was reiterated by diplomats from the two other countries. A Swedish diplomat working with Scandinavian collaboration declared: 'We think that cooperation will lead to something better. We are bigger together, and can get more traction.' Similarly, a Danish diplomat working with gender equality talked about the potential of the Nordic gender-equality work: 'Together we can deliver a Nordic bar for raising the standards of gender equality.' Another Danish diplomat reiterated this when talking about the Nordics and gender equality: 'I think we are seen as trustworthy. That is partly because, combined, we are weighted more, and thus our message counts.' This latter Danish diplomat praised the Nordic collaboration on the topics she was working with and emphasized its value in terms of end results:

We have such a good collaboration that we easily can get relatively strong influence. We are all small countries, so no one suspects we are running a superpower agenda, which one sometimes can think that the USA or others are. At the same time, we speak with a very strong voice because we collaborate so well.... As we are not one country, we are not suspected of having a hidden agenda.

This last quote is not directly tied to the Nordic regional brand but speaks to the advantages of collaborating and speaking with a shared Nordic voice. This also nuances the previous theme of how internal Nordic competition can stand in the way of the use of the Nordic brand. This Danish diplomat 
works within an area in which the Nordic collaboration is evidently an asset and where the Nordic bloc is spoken of favourably, which potentially makes the Nordic brand more relevant and unproblematic in that particular sphere. The context of the branding audience is thus a necessary component in any assessment of a brand's equity.

A few of the diplomats also emphasized that the Nordic brand can be inspirational and show that the gender policies promoted by the Nordic countries and others are not only possible but also an asset in both social and economic terms. Together, the Nordic countries can showcase gender equality in society across five different countries. A gender expert from the Norwegian MFA stated that in order to demonstrate that more gender-equal societies are both possible and economically viable, it is valuable to show this in practice: 'We need to show our process. Show that it is possible across different settings. Then the Nordic gender equality is valuable.' Here the Nordic imaging provides 'proof' that gender-equal societies can make financial and societal sense. In this context, several diplomats emphasized that five cases may constitute better 'proof' than a single standalone case. As a Swedish diplomat working with human rights emphasized:

We are pioneers on this [gender equality], together with our Nordic neighbours. We have ourselves had large-scale reforms on this; we have built solutions that give us legitimacy to talk about these topics now. We have introduced progressive laws and reforms over several decades. This has not gotten us quite to the finish line yet, but it has brought us far-even if there is still much left to do. The opinion in Sweden has also come far in terms of issues of equality and rights. We can thereby show our own practice to show others that equality is important in building good and strong societies.

Here, the social representation of the in-group, the Swedes, is in focus, as well as the moral obligation to take this representation, and the associated practice, and spread it. At the same time, the Nordic brand on gender equality is also discussed, as the diplomat reverts back to the 'proof' represented by the positive aspects of the Nordic way of doing gender equality. This could be a valuable aspect of the Nordic brand when it is considered desirable to point to the successfulness of this region in terms of gender equality, as well as to provide 'proof' of the value of such gender-equality policies.

\section{Conclusion}

As can be seen above, the interviewed diplomats mostly focused on the negative or non-functional sides of the Nordic brand. According to Browning (2015: 284), 'states and nations have always, and necessarily so, paid attention to matters of image representation and identity cultivation in their relations with others'. A brand is thereby successful if it manages to be known as 
something better than other brands, on relevant criteria: 'As such, the brand becomes something people recognize, admire and even aspire to have or associate with' (Browning, 2007: 29). Browning further emphasizes, however, that brands can also come across as outdated or unsuccessful, in that they may seem worse than other brands or lose popularity.

The interviewed diplomats all shared a strong awareness of the potentially negative sides of the Nordic brand, while most also mentioned the potentially positive aspects. These characteristics can be understood as examples of brand equity - assets and liabilities linked to the brand. The liabilities may be particularly challenging when dealing with brand alliances and co-branding (see Keller and Lehmann, 2006), as the imaging of the region depends on and varies with several actors. For example, when Sweden adopted its feminist foreign policy in 2014, this may also have influenced the Nordic gender-equality brand. This is a particular risk, as one Norwegian diplomat pointed out, since many see the Nordic region as a single entity, so that what one country does can be seen as something that all five countries do and may thus be linked to the Nordic brand in general. Dinnie (2015) speaks of national brand alliances, where both negative and positive spillover effects are possible. Countries can opt out of or downplay national brand alliances to avoid stigma. For example, Ghana could focus on its country identity over the West African identity during the Ebola crisis. Focusing on the national brand rather than the regional brand is also linked to the core of branding, namely, differentiation. The chapter thus speaks to how these Scandinavian diplomats manoeuvre the Nordic and national brands, and how they actively attempt to avoid applying the Nordic brand.

There were occasions, however, when several of the diplomats emphasized the value of applying the Nordic brand, particularly in relation to the idea that there was strength in numbers when advocating for different Nordic approaches to gender equality. Several also stated that there could have been more collaboration between the individual countries, but that gender equality is a topic that is often marked by Nordic competition.

It should be noted that other diplomats specifically praised the Nordic cooperation, so the narratives on Nordic cooperation over competition vary with the sector of the MFAs in question as well as with the individual diplomats interviewed. Browning (2007: 30) emphasizes that discussions regarding the shared Nordicity can be difficult: 'Nordic identity means different things to different people in different locations.' This variation is also evident in approaches to gender equality, as well as in questions related to internal collaboration and competition, as demonstrated in the various accounts elsewhere in this volume. This brings us back to Magnus' (2016) questioning of whether the Nordic is a meaningful brand at all, given the challenges entailed by a brand identity that encompasses five different nations. Either way, comments by the diplomats interviewed for this study suggest that the Nordic brand may have more negative aspects than positive ones in the context of their work on gender equality. The internal and external imagining 
of the Nordic countries as gender champions may have come at a cost, with connotations of moral superiority and utopian (or dystopian, depending on the audience) characteristics of the Nordic model.

\section{Notes}

1 Norway was vying for a seat on the Security Council for the period 2021-2022, and Sweden for the period 2017-2018. Both were successful in attaining their seats on the Council. The campaigns for a seat on the UN Security Council are relevant arenas for seeing how these countries' foreign ministries use (or avoid) their brand as superpowers on gender equality.

2 I did attempt to sample on diversity criteria, to include more men, but, as one diplomat said: 'If you want to talk about security, you get more men; about gender equality, more women,' indicating that gender divisions are still present in the gender-equality-focused halls of the Scandinavian ministries of foreign affairs.

3 See Swedish government communication on gender equality policy, Skr, 1999/2000: 24, p. 6.

\section{References}

Angell SI and Mordhorst M (2015) National reputation management and the competition state. Journal of Cultural Economy 8(2): 184-201.

Bailey R and Ball S (2006) An exploration of the meanings of hotel brand equity. Service Industries Journal 26(1): 15-38.

Browning CS (2007) Branding Nordicity: Models, identity and the decline of exceptionalism. Cooperation and Conflict 42(1): 27-51.

Browning C (2015) Small-state identities: Promotions past and present. In: Clerc L, Glover N and Jordan P (eds) Histories of Public Diplomacy and Nation Branding in the Nordic and Baltic Countries: Representing the Periphery. Leiden: Brill-Nijhoff, 281-300.

Clark N (2010) Nordic nations remain gender-equality leaders. New York Times, 12 October. Available at: https://www.nytimes.com/2010/10/12/world/12gender.html (accessed 20 July 2020).

Davcik NS, Vinhas da Silva R and Hair JF (2015) Towards a unified theory of brand equity: Conceptualizations, taxonomy and avenues for future research. Journal of Product \& Brand Management 24(1): 3-17.

Dinnie K (2015) Nation Branding: Concepts, Issues, Practice. Abingdon: Routledge.

Glover N (2009) Imaging community: Sweden in 'cultural propaganda' then and now. Scandinavian Journal of History 34(3): 246-263.

Hansen L and Wæver O (eds) (2002) European Integration and National Identity: The Challenge of the Nordic States. London: Routledge.

Jezierska K and Towns A (2021) Variations on shared themes: Branding the Nordics as gender-equal. In: Larsen E, Moss SM and Skjelsbæk I (eds) Gender Equality and Nation-Branding in the Nordic Region. Abingdon: Routledge, 39-61.

Jordan P (2015) Walking in singing: Brand Estonia, the Eurovision Song Contest and Estonia's self-proclaimed return to Europe, 2001-2002. In: Clerc L, Glover $\mathrm{N}$ and Jordan P (eds) Histories of Public Diplomacy and Nation Branding in the Nordic and Baltic Countries: Representing the Periphery. Leiden: Brill-Nijhoff, 217-236. 


\section{Sigrun Marie Moss}

Keller KL (1993) Conceptualizing, measuring, and managing customer-based brand equity. Journal of Marketing 57(1): 1-22.

Keller KL and Lehmann DR (2006) Brands and branding: Research findings and future priorities. Marketing Science 25(6): 740-759.

Lagerspetz M (2003) How many Nordic countries? Possibilities and limits of geopolitical identity construction. Cooperation and Conflict 38(1): 49-61.

Larsen E (2021) 'The gender-progressive Nordics': A matter of history. In: Larsen E, Moss SM and Skjelsbæk I (eds) Gender Equality and Nation-Branding in the Nordic Region. Abingdon: Routledge, 13-38.

Liinason M (2018) Borders and belongings in Nordic feminisms and beyond. Gender, Place \& Culture 25(7): 1041-1056.

Magnus J (2016) International branding of the Nordic region. Place Branding and Public Diplomacy 12: 195-200.

Melby K, Ravn A and Wetterberg CC (eds) (2009) Gender Equality and Welfare Politics in Scandinavia: The Limits of Political Ambition? Bristol: Policy Press.

Ministry for Foreign Affairs, Sweden (2019) Handbook: Sweden's Feminist Foreign Policy. Stockholm: Ministry for Foreign Affairs. Available at: https:// www.government.se/4ae557/contentassets/fc115607a4ad4bca913cd8d11c2339dc/ handbook---swedens-feminist-foreign-policy.pdf (accessed 20 July 2020).

New York Times (2005) Nordic gender gap is thinner. 17 May. Available at: https:// www.nytimes.com/2005/05/17/business/worldbusiness/nordic-gender-gap-isthinner.html (accessed 20 July 2020).

Rastas A (2012) Reading history through Finnish exceptionalism. In: Loftsdóttir $\mathrm{K}$ and Jensen L (eds) Whiteness and Postcolonialism in the Nordic Region: Exceptionalism, Migrant Others and National Identities. Abingdon: Routledge, 89-103.

Ringmar E (2002) The recognition game: Soviet Russia against the West. Cooperation and Conflict 37(2): 115-136.

Skjelsbæk I and Tryggestad TL (2021) Protecting the brand? The hesitant incorporation of gender equality in the peace nation. In: Larsen E, Moss SM and Skjelsbæk I (eds) Gender Equality and Nation-Branding in the Nordic Region. Abingdon: Routledge, 113-133.

Solheim MCW and Moss SM (2021) Inter-organizational learning within an organization? Mainstreaming of gender policies in the Swedish Ministry of Foreign Affairs. The Learning Organization. Advance online version. https://doi. org/10.1108/TLO-05-2020-0103

Towns A (2002) Paradoxes of (in)equality: Something is rotten in the gender equal state of Sweden. Cooperation and Conflict 37(2): 157-179.

Van Ham P (2001) The rise of the brand state: The postmodern politics of image and reputation. Foreign Affairs 80(5): 2-6.

Van Ham P (2008) Place branding: The state of the art. The Annals of the American Academy of Political and Social Science 616(1): 126-149. 


\title{
4 Keeping Sweden on top \\ Rape and legal innovation as nation-branding
}

\author{
May-Len Skilbrei
}

For several decades, Sweden has taken great pride in being considered at the forefront of gender-equality policies, and the current government has declared itself to be the world's first feminist government (Regeringskansliet, 2019). While this means that feminist insights are to guide the government in all matters, one policy area has for several decades already been guided by feminist analysis and aims: sexual violence. Sexual violence is linked to gender equality both in the sense that it is deemed to exist because of lack of such equality and because its existence is defined as being a barrier to gender equality. Sexual violence thus becomes not just an important policy area, but also one that serves as a barometer for the state of the nation in an area that is important to Sweden: gender equality. This chapter explores how rape legislation has been used as nation-branding to keep Sweden on top, and how the desire to remain a norm entrepreneur impacted on legal revisions. Sweden's legislation on gender and violence has been presented as an important political achievement, but it has also partly led to an increase of reported rapes. This chapter discusses this paradox, and how the paradox influences the branding of Sweden.

\section{Legislation as inspiration}

In the platform for the 'first feminist government in the world', the Swedish government stated that gender equality is a given in a 'modern welfare society', and that one of the instruments for achieving it is to put an end to men's violence against women (Regeringskansliet, 2019). Sweden has prioritized bringing an end to men's violence against women, including sexual violence, for several decades, and the issue has been put at the top of the agenda by various white papers and, not least, a series of legislative changes. As in many countries, sexuality has been an important issue for Swedish feminism, and as a policy issue it has been marked by changes in how the balance between sexual freedom and the protection of sexual integrity has been struck. Since the middle of the 1980s, Sweden has made several major revisions to its legal framework that have expanded the reach of the criminal law into acts and situations previously considered private and/or non-intrusive. 
In the 1980s, the most important debates concerning gender and violence in a broad sense were on domestic violence and sexual abuse of minors - the so-called incest debates - but sexuality per se came to the fore from the 1990s onwards, which turned out to be a decade in which criminal laws on sexuality multiplied. This was possible because sexual integrity had become a central social value in Swedish society, and sex-crime legislation has been enacted, and subsequently revised, to protect sexual integrity. Through a series of white papers, matters considered to be about gendered harms were placed at the top of the political agenda, and debates about rape law formed part of this movement towards greater governmental intervention. Several policy steps and processes led to the issuing of the 1998 Act on Violence Against Women (Government Bill 1997/1998: 55), which established a continuum-of-violence perspective (Kelly, 2012) within Swedish law in the sense that it addressed sexual harms in a broad way, criminalizing breaches of personal and sexual integrity in the small and the large, the public and the private. The package of reforms that made up the Act on Violence Against Women marked a radical shift that brought a broad range of acts within the same legal and analytical framework (for an analysis of this package, see Leander, 2005). Female genital mutilation, stalking, domestic violence, rape and prostitution were addressed as part of the same phenomenon - as expressions of gendered power relations and as crimes that men systematically commit against women. Several of the components of the law package were considered legal innovations, such as the 1999 unilateral ban on the purchase of sex and the 2000 ban on 'gross violation of a woman's integrity'. These innovations, as well as the larger law package of which they formed a part, attracted national and international attention and played a part in branding the nation and creating Sweden's reputation as a women-friendly nation and, not least, a country where law, including criminal law, is used as a key instrument for achieving gender equality (Svensson and Gunnarsson, 2018). The legislative package was intended to communicate acceptable norms and acts to the population and to broaden the police's reach into domains and acts that were previously considered private.

Subsequent revisions of Sweden's Criminal Code have also followed shifts in the normative climate on gender, sexuality and violence. Proponents of legal revisions argued that these would serve to push social norms further, making law serve as a vehicle for social transformation (Burman, 2010). Criminal law thus serves not just instrumental purposes but also more expressive ones, and this has been an explicit aim of legislative change on sex crimes in Sweden. That criminal law is intended to be both instrumental and expressive is not exclusive to Sweden, but Swedish criminologist Henrik Tham (2001) has argued that such an approach is considered more legitimate in Sweden than elsewhere. This type of approach means that laws are not just understood as having expressive characteristics; they are explicitly designed with that intent. Particularly important here is how criminal law in Sweden is considered a means of achieving gender equality (Burman, 2010). 
As previously mentioned, sex crimes are viewed in Sweden as something that both stems from and produces gender inequality, so combating sex crimes is a way of both protecting individual victims and ensuring the gender equality of all. But the audience for legal revisions is not just domestic. In the case of the revisions to the law made in the late 1990s, Swedish politicians stated that their progressiveness would also serve as an inspiration to other countries (Kulick, 2003). It is this ambition that I hone in on in this chapter. In order that it might serve as an example to the rest of the world, a particular development has to contribute to the impression that the Swedish way leads to success. In the last few years, however, Sweden has seen a steep increase in the number of cases of rape reported to the police (see, for example, Amnesty International, 2019), which gives rise to something of a paradox: If Sweden is the gender-equality haven that various international rankings and Sweden itself have claimed it is, why is it that rape is on the rise? While there are good reasons to not just take the figures on reported cases of rape at face value, it is also not entirely easy to discard them. And while the figures seem to have had little effect on Sweden's image of itself, they do represent a challenge to Sweden's position as a gender-equality role model for others.

In the summer of 2018, Sweden amended its legislation on rape to criminalize sexual activities conducted 'with someone who is not participating voluntarily'. The new law replaced an act that criminalized forcing someone to undertake sexual activities 'by assault or other violence or by threat of a criminal act'. 'The new law was intended to contribute towards both expressive and instrumental aims, in the sense that it was intended to shift social norms about sexuality and power and to improve Swedish authorities' ability to prosecute in cases of rape. I argue that moving from a coercion-based definition of rape to one based on non-voluntariness was branded by those engaged in the debate surrounding the change as something that built on and strengthened Swedish values. However, making the new rape act into a part of the Swedish brand, an innovation to be exported to other countries, was not a straightforward process, as parallels to the new way in which the harm and crime of rape was formulated within Sweden already existed in many countries and had done so for hundreds of years. But, as I will demonstrate, the trick of making something 'Swedish' is not about establishing it in Sweden, but about establishing it as a particularly Swedish thing. I will demonstrate the steps that were taken to achieve precisely this goal during the presentations of and debates on the new revision to the law on rape in the Swedish parliament and the media. I particularly focus on how the desired role as a norm entrepreneur emerged during these presentations and debates. While the content of the new rape law did not constitute a legal innovation - such provisions already existed in jurisdictions on three continents - I find that key Swedish players still presented it as ground-breaking. I apply branding as an analytical lens to discern the patterns and logics involved in the presentation of the law revision as 'first' 
and/or 'best', and I view the recent revision of the rape legislation as an example of a contemporary case of ensuring the continuation of the Swedish brand. To have a distinct identity and value - that is, a brand - matters not just for the level of visibility enjoyed by a state but also for the traction it has in international forums (Viktorin et al., 2018). Small countries can 'punch above their weight' if their brand establishes them as particularly important to pay attention to. Having an established reputation as a nation that can protect its citizens from harm, including sexual harm, grants a degree of superiority in an international political climate that increasingly emphasizes protection of rights. Gender equality has been a policy area in which many international harmonizing efforts have been made (Houge et al., 2015), and to be the one to set the example, rather than the one who has to follow suit - that is, to be disciplined by other countries or the international community - can play a role in establishing a nation as a leader. In this way, feminism becomes useful to power, and the relationship between feminism and governance in Sweden may serve as an example of what Janet Halley (2018) has termed 'governance feminism', where feminism not only becomes incorporated into governance structures but also becomes part of, the performativity of state power. Feminism is indeed so ingrained in ruling in Sweden that the goals of feminism are now the goals of the 'first feminist government in the world'.

In the following sections, I will first describe the way statements regarding the extent and nature of rape were discussed in relation to Sweden's reputation as a gender-equality haven, before turning to how debates about the revisions of the rape legislation can be understood as a response to the harm done to this reputation.

\section{Bad at rape: harming the reputation of gender-progressive Sweden}

Rape is a topic that receives a lot of attention in Sweden. Information about the extent and character of rape, especially with a focus on individual cases, is integrated into debates on what policies should be applied to remedy the situation (Nilsson, 2019). The background to the attention the phenomenon has received in recent years is the fact that cases of rape reported to the police in Sweden have increased over a long period, and the numbers are among the highest per capita in Europe (Aebi et al., 2014). The high numbers of reported rapes, however, might not mean that numbers of incidents are indeed increasing. Crime statistics are sensitive to changes in reporting practices, increasing awareness in the population and increasing pressure on victims to report to prevent future crimes. That the number of reported rapes is high and increasing in Sweden may thus be interpreted to mean that the country is particularly good at raising awareness on the issue. Also, the legal definitions have changed over time, which means that acts that would not previously have been considered rape are now included, and international 
comparisons of crime statistics are made difficult by the fact that different jurisdictions may use the same term but apply wider definitions and thus lower thresholds. However, there are also findings that support the claim that there is indeed something happening in Sweden. One factor that indicates that the rise in registered cases is representative of rising incidence is that population-based victimization surveys also find that numbers of incidents have steadily risen, at least until 2017 (Swedish National Council for Crime Prevention, 2019a).

As mentioned above, one reason why the rape figures in Sweden are so high is that the legal thresholds are lower than in many other places, and public awareness and the legitimacy of reporting higher. Still, these figures nationally and internationally appear to represent a worsening of the Swedish authorities' ability to protect especially women from sexual harm. Being considered a country with many incidents of rape is uncomfortable for a country that depicts itself as being one of the most gender-equal in the world (Jezierska and Towns, 2018). Further, the high numbers alone are not the only characteristic of rape that has attracted attention in the case of Sweden. Many of the most attention-grabbing cases are multi-perpetrator rapes performed by male migrants (Nilsson, 2019). This has fuelled antiimmigrant sentiments and is something the radical right party the Sweden Democrats has been able to capitalize on (Skilbrei, 2020). In many instances, this party is trying to dismantle many rights structures that are considered key to Swedish gender-equality policies (Martinsson et al., 2017), but at the same time it takes gender equality as a core norm and has made the issue of rape a matter of national identity and protection. The party seems to start from the assumption that to be Swedish is to be gender-equal (Martinsson et al., 2017), a type of rhetoric that is facilitated by the way in which gender equality is ingrained in Swedish national identity (Grip, 2012; De los Reyes, 2017). Such a position seems to lead to two political consequences: first, that further gender-equality policies are not needed since Sweden 'has arrived' as a gender-equal society; second, that non-Swedes are what threatens the established gender and sexuality order, which enables the Sweden Democrats to argue that immigration should be curbed because it undermines the 'Swedishness' of Swedish society, including in relation to how it protects women from sexual violence. Immigration has come to be strongly associated with crime in general over the last few years (Heber, 2014), with debates on the relationship between immigration and crime typically focusing on sex crimes. Fighting immigration thus comes to be about fighting sexual violence.

The Sweden Democrats are the key proponents in domestic debates of the argument that Sweden has become 'bad at rape' because Swedish society has allowed another concern, that of being tolerant and generous towards migrants, to come before the interests of Sweden and the safety of Swedish women and girls. This is a position that can also be found in discussions of Sweden's high rape figures in the international arena. In the UK, for 
example, the leader of the right-wing party UKIP, Nigel Farage, famously stated that 'Malmo is now the rape capital of Europe, and some argue, perhaps the rape capital of the world' (Lusher, 2017). In 2016, the Turkish newspaper Günes, often presented as a communication channel for the Turkish government, warned Turkish citizens against travelling to Sweden on their front page, under the heading 'Sweden, a Country of Rape', as well as via the hashtag \#DontTravelToSweden on their Twitter account (Local, 2016). Shortly after, a poster apparently funded by Günes was hung at Istanbul Atatürk Airport (Middle East Eye, 2016). The poster included a picture of the front page mentioned above with the additional text 'Travel warning! Did you know that Sweden has the highest rape rate worldwide?' (see Figure 4.1).

The extent of rape is not the only challenge to the Swedish brand as a gender-equality haven. The accusation that Swedish authorities are unable to deliver justice to victims is equally problematic. Very few reported cases of rape end in a conviction, and this is spoken of as the 'justice gap' that is considered an expression of how 'laws may have been stripped of their most blatantly misogynistic manifestations, but the processing of rape cases through the criminal justice system remains problematic' (Temkin and Krahé, 2008: 1). As previously mentioned, the number of reported cases of rape in Sweden is high and increasing every year, at the same time as prosecution and conviction rates are dropping (Swedish National Council for Crime Prevention, 2019b), which means that the discrepancy between reported cases and convictions is increasing. Taken together, high numbers and high attrition

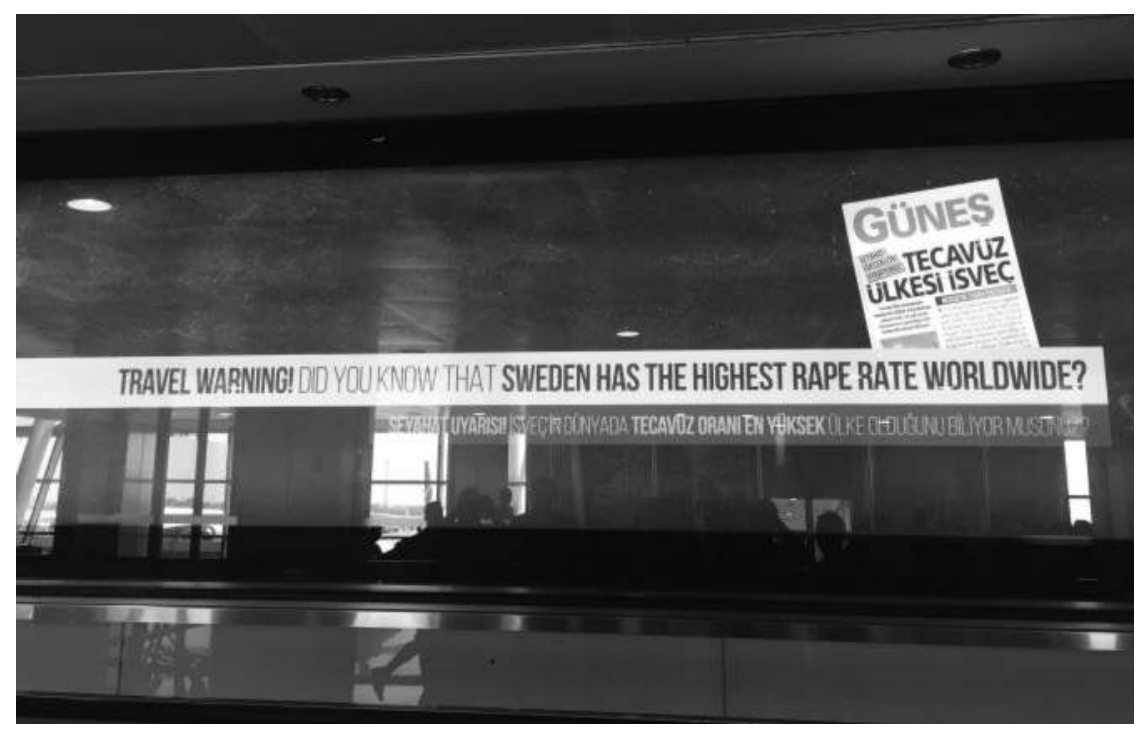

Figure 4.1 Travel Warning Poster, Istanbul Atatürk Airport, 2016.

Source: Anadolu Agency (AA). 
rates seriously threaten the image of Sweden as a moral authority, as this image relies on Sweden's capacity to provide gender equality and protection of sexual integrity. Other problems, such as long delays throughout the criminal justice process, have also been critiqued. A blow was delivered to Sweden's reputation, for example, when the UN special rapporteur on violence against women in 2007 concluded that Swedish gender-equality policies were not effective in addressing issues related to gender and power (see Edgren, 2019). In 2019, Sweden's poor performance in securing convictions was also highlighted by the Group of Experts on Action against Violence against Women and Domestic Violence (GREVIO, 2019), the control body for the Council of Europe's Convention on Preventing and Combating Violence against Women and Domestic Violence, commonly referred to as the Istanbul Convention. Taken together, these developments make Sweden look like a country that is unable to provide justice to victims and is marked by a lack of gender equality.

There are thus several different aspects involved in current attacks on Sweden's position as an authority on gender equality generally, and on the protection of women against sexual violence specifically. The fact that these developments undermine the message that Sweden wants to convey about itself means that the role the Swedish government has had in international forums in the field of sexual violence may suffer. Sweden has been considered a driving force in shifting European and global agendas (for example, by making the fight against violence against women and girls a priority in its foreign policy; see Tham et al., 2011), and the Swedish authorities also take their country's global reach and impact into consideration when designing policies (Towns, 2002; Holmström and Skilbrei, 2017). Poor performance on these issues at home is something that may reduce Swedish traction abroad, and thus harm the nation brand's legitimacy on this point (see the chapters by Hellum and Erlingsdóttir in this volume for the potential ramifications of pushing norms abroad that one is not performing particularly well on domestically).

The critique of how Sweden approached rape came from several directions at the same time, involving both a critique of the government for prioritizing tolerance towards migrants over the safety of its citizens and a critique from a more traditional feminist position that victims of rape are not provided with adequate justice. In the light of the strong reactions this threat to the image of Sweden as a gender-equality haven has generated in Sweden, it would not be surprising if this critique was one of the reasons why a legislative proposal that had not moved forward since it was issued in 2016 was once again back on the table in 2018.

\section{Taking charge of Sweden's image so that the world looks to Sweden}

To be presented as a country unable and unwilling to protect its citizens from rape, and unable to deliver justice if they are subjected to rape, is 
something that is difficult to combine with building a brand as the 'first feminist government in the world'. There had been ongoing debates in Sweden about whether to revise the rape law for some time, especially after the 2016 white paper, but the issue gained momentum during the various critiques the government was subjected to. There are also other valid explanations for why the revision to the law occurred when it did, but I will not go into these now. What I am interested in here is to identify what in these debates can be interpreted as key strategies for reinstating the value of the Swedish brand as a gender-equality haven to the world. There have been two discernible strategies for alleviating the threat to the brand posed by the problematic situation regarding rape in Sweden.

The first strategy was for politicians to argue that there is no reason to problematize rape in Sweden by rejecting the whole premise that Sweden was experiencing a large increase in the numbers of rapes. I have credible reports of several incidents where Swedish politicians have commented on the figures off-camera in supranational forums. One example is when a representative of the government of a European country contacted me to inquire whether Swedish claims that the number of rapes in Sweden had consistently decreased over several years were correct. One such incident was also caught on-camera, and this episode ended in a public retraction. This was when Swedish Minister for Employment and Integration Ylva Johansson was interviewed by BBC Newsnight in 2017. During the interview, Johansson was confronted with the increasing levels of reported rapes in Sweden. She responded, 'We can see that the level is going down, and going down, and going down' - a statement she would later have to retract (Local, 2017). That a representative of the Swedish government would argue that rape was on the decline during a period in which crime statistics showed a steep increase may give us some idea of just how much is at stake. It is also interesting that high rape figures in Sweden attract so much attention that that the $\mathrm{BBC}$ considered the matter worth covering. That Johansson was caught in a lie brought fuel to the fire for anti-immigrant debaters that were already arguing that the Swedish government was lying to its own population about the consequences of migration for society.

The second strategy in debates leading up to 2018 was to shift the attention from the actual situation to the planned revision to the law, thus changing the narrative on rape. Instead of discussing what it had not done, the Swedish government was instead able to direct attention to what it was doing. What it was doing might not be very radical, but key debaters presented the law revision as a progressive and brave move. One aspect of this was the way the 'Swedish approach' to rape was represented as social norms that the legal norms had to 'catch up' with. The existing legislation was thus considered out of sync with the progressive views and practices of the population. The new rape law of 2018, which establishes that voluntariness is the premise for 'just sex' (a term from Cahill, 2016), not non-force, was intended not just to align with but also to strengthen social norms 
about sexuality and power (Andersson et al., 2019: 3). A key argument in Swedish debates about law is that laws need to be in alignment with prevailing social norms; not only that, they should also express what the values are to fortify them. Tham (2001: 416) has identified this as a key component of the expressive character of law in Sweden, whereby laws should be 'demonstrating (perceived) central social values'. This point is important in the context of the present discussion, as the value of expressing Sweden's emphasis of the protection of sexual integrity is intended to reach far beyond Sweden. The claim that the law revision was a response to the progressiveness of the population under-communicates two discernible contexts to the law. First, few mentions are made in debates to the fact that similar laws already existed in many jurisdictions, including jurisdictions that are normally not considered progressive or gender-equalityminded. While the 2016 white paper on rape law makes references to the fact that consent-based rape laws exist in many countries, the failures and successes of those examples did not inform discussions about whether Sweden should introduce a similar law either in that document or in subsequent debates. Whether Sweden should revise its rape law was generally not discussed in terms of the country following in the footsteps of other countries, but instead in terms of leading the way. Possible benefits of and problems with different formulations were discussed with reference to particular Swedish cases and hypothetical situations, instead of through an examination of how penal codes in other countries are formulated and seem to work. That experiences elsewhere were not a natural frame of reference was noticeable throughout the debates (Nilsson, 2019), as well as after the law revision was in place. At that point, several powerful actors presented the revision as a legal innovation and a new way of addressing rape born from the fact that Sweden is one of the most gender-equal countries in the world.

Perhaps the most noteworthy example of this is how leading Swedish legal scholar Madeleine Leijonhufvud (2017) discussed the upcoming law revision in a TED talk published on 25 May 2017:

Remember when Neil Armstrong stepped out of the lunar module, that day in July 1969, and stepped onto the moon? A small step for a man, a giant leap for mankind, Armstrong said. Well, a giant leap for mankind, at least for the part of it here in Sweden, it'll mean when we change our rape law to a consent based law".

While Leijonhufvud towards the end here modifies the claim by mentioning that this is an approach new to Sweden, implicating that she is well aware that this way of defining rape is not new to the world, she goes on to describe consent-based rape law as a radical legal innovation, as "a rethinking of the whole issue of sexual behaviour", one that departs from the "outlook that has guided mankind" (2017). 
Leijonhufvud is not just anyone. She has been one of the main proponents of a consent-based law in Sweden for 20 years (see, for example, Leijonhufvud, 2008) and was a force to be reckoned with in public debates in Sweden.

That a country that undertakes brave moves to address sexual harm might link this to taking a strong position on sexual integrity and gender equality is very understandable, but what was under-communicated here was the fact that Sweden was very far from being the first country in the world to introduce a consent-based definition of rape in penal law. In Anglo-American jurisdictions, this is the norm, which means that England and Wales, and many of the England's former colonies, already have such legislation. Rape legislation elsewhere is addressed briefly in the white paper that preceded the revision, which states that the committee has assessed the experiences of a handful of countries (Regeringskansliet, 2016), but references to the success - or lack thereof - of prosecution of rape in countries such as England and Wales, Luxembourg, Belgium, India, Ireland, Scotland, Germany, Cyprus, Canada, parts of Australia (at least Canberra) and Mexico were not included in debates. Further strengthening the impression that the law was presented as 'a first' is some of the media coverage of its introduction. For example, Svenska Dagbladet (2018), one of Sweden's largest newspapers, in the coverage of the introduction of the new act, stated that "the [Swedish] consent law has both been criticized, heralded and attracted attention abroad'. I would argue that the absence of references to experiences elsewhere is notable, and that there is reason to believe that it speaks to a need to be seen as 'the first', even when this was not the case.

The second context of the law that was under-communicated in debates was its relationship to international obligations. The fact is that European jurisdictions are under pressure from NGOs and others to revise their rape laws to explicitly criminalize non-consensual sex. It is notable that debaters did not draw on such obligations to build the argument that Sweden should follow suit. This is particularly relevant in relation to the obligations Sweden has under the Istanbul Convention. Several NGOs active in the Nordic region have argued that the Convention mandates a consent-based definition of rape, and this has been a key argument in debates about law revisions in neighbouring Norway (Amnesty International, 2019). As available arguments are not applied, one may suspect that framing the matter as stemming from national values and 'Swedishness', rather than as a response to international obligations, serves a purpose (see, for example, Holst, 2018: 113).

When branding is viewed as an issue of representation (Clerc and Glover, 2015), the question of whether the revised rape act really represents something new becomes unimportant. Similar acts already existed, but this way of defining rape had not been branded 'Swedish' previously, which means that the definition was transformed from an old relic of common-law countries, typically in England and Wales and former English colonies, to a modern feminist law representing the modern and progressive will of the 
people. A discernible difference between rape laws that were already in place elsewhere and the Swedish rape law was also established by terminology. While the law was explicitly intended to address acts where 'consent' was not present, the law uses the term 'voluntariness'. The two terms have the same meaning in this context, and they are also used interchangeably in the white paper. The same document also acknowledges that the new law is indeed a consent-based law (Regeringskansliet, 2016: 45): 'The legislation we propose is usually referred to in the public debate as consent-based legislation.' In preparatory works, it is stated that this is meant to encompass situations where there has been an 'expression of voluntariness' and 'an expressed choice to participate voluntarily' (Regeringskansliet, 2016: 48), and consent must be assumed to be equal to 'an expression of voluntariness'. The main reason why the Swedish authorities chose to replace the more common term 'consent' with a formulation that serves as a synonym is expressly technical: there is already a concept of consent in the Swedish Criminal Code that should not be confused with the one applied in rape law, but the change of term has the effect of causing the rape act to appear unique to Sweden.

\section{Conclusion}

The example discussed here is a case of a strong brand being under threat from both national and international actors, and the chapter presents and discusses efforts that through their effects, and perhaps also by intention, reinstate Sweden as 'best' on protecting its citizens from sexual harm, and 'first' in the sense that policies in Sweden are assumed to be followed by others.

Experiences from other countries have shown that consent-based rape law is not inherently feminist. Rape laws are difficult to prosecute in countries with and without consent-based laws. The active referencing and reception of the new rape law as 'Swedish' contributed to establishing a situation where this particular way of formulating the crime of rape became feminist by being appropriated in Sweden, as feminism is understood as guiding all policy developments in that country. By introducing a law revision that can be represented as feminist, and therefore innovative, feminism has aided the Swedish state in its desired performance as a trailblazer (Halley, 2018).

Referring to Valaskivi's (2016) study of nation-branding in Finland and Sweden, Jezierska and Towns (2018) note that Sweden's efforts to market itself internationally valorize being 'first'. In the particular case under examination here, the law revision could have been presented as a case of Sweden looking to other countries for examples and adopting a policy that existed elsewhere, but this did not happen. Both at home and internationally, it has been under-communicated that this was not a revolutionary law. The Swedish rape law thus takes on the appearance of being yet another Swedish legal innovation in the area of sexual violence, and this may contribute to branding consent-based law as Swedish. Indeed, as Sweden is often regarded as 
a model for others to emulate (Jezierska and Towns, 2018), a consent-based definition of rape might not have been considered the ultimate feminist solution until it was adopted by Sweden. As consent-based rape law comes to be presented as Swedish and feminist, Sweden in a sense becomes the 'first' country to introduce consent-based rape law for 'the right reason', based on a modern gender-equality argument. The Swedish rape law in this way may take the form of a 'political myth', in Della Sala's (2010) sense, representing Sweden as an innovator also in the field of rape. I have already found formulations in international blogs and media that contain encouragements to 'follow Sweden' in this area (see, for example, Skovira [2018] for a petition to the Danish prime minister to 'follow Sweden's lead'), which indicates that Sweden has already claimed or been given ownership of a policy that already existed elsewhere - in countries, however, that others are less eager to emulate.

The international negative attention to the levels and characteristics of sexual violence in Sweden and the lack of justice for victims cannot alone explain why Sweden made a major revision to its rape law at the time it did, but how that revision is represented may in part be a response to such negative attention.

\section{Note}

1 The first formulation is from Brottsbalk (the Swedish term for the Penal Code) 6: 1, Law 2018: 618, the second from the former version of Section 1 of Brottsbalk 6.

\section{References}

Aebi MF, Akdeniz G, Barclay G, Campistol C, Caneppele S, Gruszczyńska B, Harrendorf S, Heiskanen M, Hysi V, Jehle JM, Jokinen A, Kensey A, Killias M, Lewis CG, Savona E, Smit P and Pórisdóttir R (2014) European Sourcebook of Crime and Criminal Justice Statistics 2014, 5th edn. Helsinki: HEUNI.

Amnesty International (2019) Time for change: Justice for rape survivors in the Nordic countries. London: Amnesty International. Available at: https://www. amnesty.org/download/Documents/EUR0100892019ENGLISH.PDF (accessed 20 January 2020).

Andersson U, Edgren M, Karlsson L and Nilsson G (2019) Introductory chapter: Rape narratives in motion. In: Andersson U, Edgren M, Karlsson L and Nilsson G (eds) Rape Narratives in Motion. Cham: Palgrave Macmillan, 1-16.

Burman M (2010) Rethinking rape law in Sweden: Coercion, consent and nonvoluntariness? In: McGlynn $\mathrm{C}$ and Munro VE (eds) Rethinking Rape Law: International and Comparative Perspectives. Abingdon: Routledge, 196-208.

Cahill, A J (2016) Unjust sex vs. Rape. Hypatia, 31(4): 746-761.

Clerc L and Glover N (2015) Representing the small states of Northern Europe: Between imagined and imaged communities. In: Clerc L, Glover N and Jordan P (eds) Histories of Public Diplomacy and Nation Branding in the Nordic and Baltic Countries: Representing the Periphery. Leiden: Brill-Nijhoff, 3-20.

De los Reyes P (2017) When feminism became gender equality and anti-racism turned into diversity management. In: Martinsson L, Griffin G and Giritli 
Nygren K (eds) Challenging the Myth of Gender Equality in Sweden. Bristol: Policy Press, 21-48.

Della Sala V (2010) Political myth, mythology and the European Union. JCMS: Journal of Common Market Studies 48(1): 1-19.

Edgren M (2019) Conditional vulnerability: Rape narratives in Swedish courts, 1990-2014. In: Andersson U, Edgren M, Karlsson L and Nilsson G (eds) Rape Narratives in Motion. Cham: Palgrave Macmillan, 43-70.

Erlingsdóttir I (2021) Trouble in paradise? Icelandic gender-equality imaginaries, national rebranding and international reification. In: Larsen E, Moss SM and Skjelsbæk I (eds) Gender Equality and Nation-Branding in the Nordic Region. Abingdon: Routledge.

Government Bill 1997/1998 (1998) Kvinnofrid. Stockholm: Government of Sweden.

Grip L (2012) The (dis)similarity paradox in Swedish integration policies: The case of immigrant women as templates. In: Samuelsson MJ, Krekula C and Åberg M (eds) Gender and Change: Power, Politics and Everyday Practices. Karlstad: Karlstad University Press, 149-164.

Group of Experts on Action against Violence against Women and Domestic Violence (GREVIO) (2019) Baseline Evaluation Report Sweden. Strasbourg: Council of Europe. Available at: https://rm.coe.int/grevio-inf-2018-15-eng-final/168091e686 (accessed 24 July 2020).

Halley J (2018) Where in the legal order have feminists gained inclusion? In: Halley J, Kotiswaran P, Rebouché R and Shamir H (eds) Governance Feminism: An Introduction. Minneapolis: University of Minnesota Press, 3-22.

Heber A (2014) Good versus bad? Victims, offenders and victim-offenders in Swedish crime policy bills. The European Journal of Criminology 11(4): 410-428.

Hellum A (2021) Not so exceptional after all? Nordic gender equality and controversies linked to the Convention on the Elimination of All Forms of Discrimination against Women. In: Larsen E, Moss SM and Skjelsbæk I (eds) Gender Equality and Nation-Branding in the Nordic Region. Abingdon: Routledge, 173-190.

Holmström C and Skilbrei ML (2017) The Swedish sex purchase act: Where does it stand? Oslo Law Review 1(2): 82-104.

Holst C (2018) Scandinavian feminism and gender partnership. In: Witoszek N and Midttun A (eds) Sustainable Modernity: The Nordic Model and Beyond. Abingdon: Routledge, 102-118.

Houge AB, Lohne K and Skilbrei ML (2015) Gender and crime revisited: Criminological gender research on international and transnational crime and crime control. Journal of Scandinavian Studies in Criminology and Crime Prevention 16(2): $160-174$.

Jezierska K and Towns A (2018) Taming feminism? The place of gender equality in the 'progressive Sweden' brand. Place Branding and Public Diplomacy 14(1): $55-63$.

Kelly L (2012) Preface: Standing the test of time? Reflections on the concept of the continuum of sexual violence. In: Brown JM and Walklate SL (eds) Handbook on Sexual Violence. New York: Routledge, xvii-xxv.

Kulick D (2003) Sex in the new Europe: The criminalization of clients and the Swedish fear of penetration. Anthropological Theory 3(2): 199-218.

Leander K (2005) Reflections on Sweden's measures against men's violence against women. Social Policy and Society 5(1): 115-125.

Leijonhufvud M (2008) Samtyckesutredningen: lagskydd för den sexuella integriteten. Stockholm: Thomson. 
Leijonhufvud M (2017) The revolution of consent. TEDx Talks, 25 May. Available at: https://www.youtube.com/watch?v=AB_8vRcvyIw (accessed 23 July 2020).

Local (2016) Newspaper tells Turks 'don't go to Sweden'. 19 August. Available at: https://www.thelocal.se/20160819/airport-ad-tells-turks-dont-go-to-sweden (accessed 12 August 2020).

Local (2017) Swedish minister does U-turn on comments about Sweden's sex crimes. 4 March. Available at: https://www.thelocal.se/20170304/fake-news-ministerdoes-u-turn-on-comments-about-swedens-sex-crimes (accessed 6 October 2019).

Lusher A (2017) Nigel Farage echoes Donald Trump by claiming Sweden is 'rape capital' of Europe. This is why they're wrong. Independent, 21 February. Available at: https://www.independent.co.uk/news/uk/politics/nigel-farage-sweden-donaldtrump-rape-capital-of-europe-refugees-malmo-why-wrong-debunkedclaim-a7591636.html (accessed 24 July 2020).

Martinsson L, Griffin G and Giritli Nygren K (2017) Introduction: Challenging the myth of gender equality in Sweden. In: Martinsson L, Griffin G and Giritli Nygren K (eds) Challenging the Myth of Gender Equality in Sweden. Bristol: Policy Press, 1-22.

Middle East Eye (2016) Turkey airport ad accuses Sweden of having 'highest' global 'rape rate'. 19 August. Available at: https://www.middleeasteye.net/fr/news/turkeyairport-ad-accuses-sweden-highest-global-rape-rate-896332178 (accessed 24 July 2020).

Nilsson G (2019) Towards voluntariness in Swedish rape law: Hyper-medialised group rape cases and the shift in legal discourse. In: Heinskou M, Skilbrei ML and Stefansen K (eds) Rape in the Nordic Countries: Continuities and Change. Abingdon: Routledge, 101-119.

Regeringskansliet (2016) Ett starkare skydd för den sexuella integriteten: Betänkande av 2014 års sexualbrottskommitté. SOU 2016: 60. Available at: https:// www.regeringen.se/rattsliga-dokument/statens-offentliga-utredningar/2016/10/ sou-201660/ (accessed 24 July 2020).

Regeringskansliet (2019) Faktablad: En feministisk regering. Available at: https:// www.regeringen.se/informationsmaterial/2019/03/en-feministisk-regering/ (accessed 1 July 2020).

Skilbrei ML (2020) Criminological lessons on/from sexual violence. In: Walklate S, Fitz-Gibbon K, McCulloch J and Maher JM (eds) The Emerald Handbook on Feminism, Criminology and Social Change. Bingley: Emerald, 357-372.

Skovira I (2018) Make sex without consent punishable by law. Forcechange.com. Available at: https://forcechange.com/503113/make-sex-without-consent-punishableby-law/ (accessed 24 July 2020).

Svenska Dagbladet (2018) Från och med nu krävs samtycke vid sex. 30 June. Available at: https://www.svd.se/fran-och-med-nu-kravs-samtycke-vid-sex (accessed 15 May 2020).

Svensson EM and Gunnarsson $\AA$ (2018) Structuralism versus individualism in Swedish gender equality policy. NORA - Nordic Journal of Feminist and Gender Research 26(3): 230-237.

Swedish National Council for Crime Prevention (2019a) Nationella trygghetsundersökningen 2018. BRÅ-rapport 2019: 11. Stockholm: Swedish National Council for Crime Prevention. 
Swedish National Council for Crime Prevention (2019b) Våldtäkt från anmälan till dom. En studie av rättsväsendets arbete med våldtäktsärenden. Stockholm: The Swedish National Council for Crime Prevention.

Temkin J and Krahé B (2008) Sexual Assault and the Justice Gap: A Question of Attitude. Oxford: Hart Publishing.

Tham H (2001) Law and order as a leftist project? Punishment \& Society 3(3): 409-426.

Tham H, Rönneling A and Rytterbro LL (2011) The emergence of the crime victim: Sweden in a Scandinavian context. Crime and Justice 40(1): 555-611.

Towns A (2002). Paradoxes of (in)equality: Something is rotten in the gender equal state of Sweden. Cooperation and Conflict: Journal of the Nordic International Studies Association 37(2): 157-179.

Valaskivi K (2016) Circulating a fashion: Performance of nation branding in Finland and Sweden. Place Branding and Public Diplomacy 12(2-3): 139-151.

Viktorin C, Gienow-Hecht JCE, Estner A and Will MK (2018) Beyond marketing and diplomacy: Exploring the historical origins of nation branding. In: Viktorin C, Gienow-Hecht JCE, Estner A and Will MK (eds) Nation Branding in Modern History. New York: Berghahn, 1-26. 


\title{
5 Trouble in paradise?
}

\author{
Icelandic gender-equality \\ imaginaries, national \\ rebranding and international \\ reification
}

\section{Irma Erlingsdóttir}

The period 1970-2020 can be characterized in terms of a slow process of tearing down gendered power structures in Icelandic political and economic life. In the 1970s and 1980s, women's movements spurred critical debates about gender inequalities, which were instrumental in putting women's rights on the political agenda. Feminist activism led to the first women's strike in 1975, during which women left their jobs or homes for a day to demonstrate the importance of their contribution to society. Another important event was the 1980 election of Vigdís Finnbogadóttir as the world's first democratically directly elected female head of state. And 1983 witnessed the electoral breakthrough of a women's only movement - the Women's Alliance - which was represented in the Icelandic parliament until 1999. In all these cases, demands for the empowerment of women deeply influenced Icelandic society and the male-dominated political parties.

These achievements, however, were followed by an anti-feminist backlash in Iceland during the first decade of the twenty-first century. What has been dubbed the 'era of masculinities' coincided with a neoliberal turn driven by a group of businessmen with the active support of the political elite (Porvaldsdóttir, 2014: 52; see also Enloe, 2013; Loftsdóttir, 2015b). This led to the adoption of privatization and deregulatory policies and an unprecedented foreign expansion of Icelandic banks and private enterprises. The masculinized boom-era culture that accompanied this business-government collusion was, of course, part of a global trend. However, its effects in Iceland were especially strong and manifested themselves in essentialist and misogynist attitudes and practices. It was a classic case of the persistence of 'hegemonic masculinity' - the attempt to legitimize, normalize and reinvent patriarchy and the subordination of women (Connell, 1998; Enloe, 2017). Women were, for instance, increasingly relegated to the 'feminine sphere' by excluding them from power positions on the grounds that they were not 'risk-takers' and were too cautious by nature (see, for example, Johnson, 2018: 49).

As a result, the feminist movement in Iceland was forced on the defensive and became less influential within political structures than it had been in previous decades. The dominant political culture was guided by neoliberal

DOI: $10.4324 / 9781003017134-5$ 
and individualistic ideas about the irrelevance of gender as a political and social category. It was not until the end of 2008 - during the height of the global financial crisis, when Iceland experienced the biggest banking collapse that a country has ever suffered relative to the size of its economy that this trend was reversed. The ensuing political and economic instability did not just challenge a masculine culture of impunity; it also created the conditions for the revival of a women's agenda in the politics and economy of Iceland based on feminist critiques of the hegemonic masculine model.

Since then, gender equality has been a central focus of Icelandic government policies, playing a major role in domestic reconstruction efforts and nation-branding abroad. What the financial crisis did was to reopen a space for women in terms of political representation and participation. On an individual and symbolic level, it began, in 2009, with the formation of a left-wing government and the appointment of Jóhanna Sigurðardóttir as Iceland's first female prime minister - and the world's first gay person to hold such a position - and continued with the appointment of Katrín Jakobsdóttir as Europe's youngest female prime minister in 2017. Finally, from 2009 to 2020, driven by the women's movement and feminist members of parliament, successive coalition governments, spanning the entire political spectrum, have enacted gender-equality laws with the aim of increasing the number of women on company boards, making equal-pay certification obligatory, extending parental leave from nine months to a whole year, and expanding abortion and transgender rights (see Prime Minister's Office, Iceland, 2019).

Nation brands have a high policy value because they create and relate to images and reputations that are deeply anchored in the minds of consumers and audiences (Viktorin et al., 2018: 3). Iceland's effort to put into effect a strong gender-equality model has been a key factor in reversing its negative image after the financial collapse - together with other important factors, such as the quick economic recovery, the defiance of powerful foreign financial and political interests, especially in Britain and the Netherlands, and the decision to bring those responsible for the financial crisis to justice. Indeed, Iceland has topped the list of the World Economic Forum's Global Gender Gap Index every year since 2009. According to the World Economic Forum's 2020 survey, Iceland has closed almost $90 \%$ of the overall 'achievement gap' between women and men in four key areas: health and survival, political empowerment, economic participation and opportunity, and educational attainment (see World Economic Forum, 2020).

In this chapter, I focus on the role of Icelandic gender-equality images in national identity projections and foreign imaginaries following the 2008 financial crash. I show that there has been a fundamental change in the gendered branding of Iceland, which is directly tied to post-crisis reconstruction discourses and practices. Before the banking collapse, Icelandic image constructions, as well as foreign perceptions of them, were in many ways characterized by gendered and sexualized representations. The master 
narrative described modern-day Viking conquerors who took the world by storm on the basis of a unique Icelandic business model, combining quick decision-making and risk-taking with the maximum flexibility of a small state. In addition, Iceland was projected as a place where a vibrant urban nightlife and female promiscuity were juxtaposed with stereotypical exotic landscapes and purity of nature (Huijbens et al., 2012).

Following the financial crisis, however, the narrative shifted rapidly from masculine reification and female objectification to that of highlighting the level of gender equality in Iceland. Rooted in earlier feminist struggles of the 1970s and 1980s, this rebranding was largely made possible by activists who used the opportunity to advance a societal critique that paved the way for the adoption of concrete gender-equality policies as a crisis-response mechanism (see Enloe, 2013: 77). Their success in promoting this progressive programme was aided by a widespread belief that there was a need to escape a stigma - an image centring on a nation willing to sacrifice itself to the highest bidder during the boom era. This feminist agenda has not only been made part of official image campaigns - and inserted into the vocabulary of advertising agencies, even if they are still under neoliberal influences - but has also been incorporated into public policy and foreign policy discourses.

\section{Sexualized imaginaries of the nation}

As Viktorin et al. (2018: 2) have pointed out, nation-branding 'seeks to enhance international credibility, draw foreign investment, create international political influence, charm tourists, intensify nation building, attract and retain talent and, often, change negative connotations'. Since the nineteenth century, gender has been an important tool in such branding. In their chapter in this volume, Katarzyna Jezierska and Ann Towns (2021) argue that a number of states, including Iceland, have relied on 'androcentric and sexually objectifying representations' in the promotion of their countries. In contrast, they argue, Sweden has avoided such gendered image-making. Before the financial crash, such a portrayal was, indeed, applicable to Iceland. In the 1990s and the 2000s, when it came to nation-branding abroad, the emphasis of private companies was not only on Iceland's natural beauty but also on the people who lived there. As part of that strategy, Reykjavík was introduced as a 'global party capital'.

To underpin highly gendered marketing campaigns, there were references to beautiful Icelandic women, including two Miss World titleholders, which fit into a broader picture of alluring and healthy Nordic women with sexually liberal attitudes (Porvaldsdóttir, 2011: 421). In the early 2000s, tourist promotional strategies reinforced the stereotypical image of Icelandic women as being promiscuous. It culminated in a highly controversial Icelandair advertising campaign in London under the heading 'Fancy a Dirty Weekend in Iceland?' - which included phrases like 'Miss Iceland Awaits', 
'One Night Stand in Reykjavík' and 'Free Dip in Every Trip'. This sexualization of the public square was underlined by the sudden increase of sex clubs in Iceland, which started in the mid-1990s, reaching a peak in 2000 when 12 such clubs were operating in Iceland, mostly in the capital area (Porvaldsdóttir, 2011: 424). Much of this nascent industry was based on trafficking in women from various countries, which drove Icelandic feminists to agitate, successfully, for the shutting down of these clubs in the years following the 2009 crisis. Originally, the target group was young men, who made up the majority of tourists visiting Iceland and who were to be tempted by a wild nightlife. This worked so well that in 2005 Reykjavík nightlife was cited by tourists as one of the five major reasons for visiting Iceland; it scored higher than nature walks, horseback-riding or whale-watching (see Icelandic Tourist Board, 2005). In other words, those in charge of marketing for Icelandic tourist companies decided that Icelandic women were to be specifically targeted, in a predatory way, as 'exotically white' sexual objects. While this trend of the hypersexualization of Icelandic women was severely criticized by Icelandic women's groups, it did not exist in a cultural vacuum; it was very much a part of the persistence of patriarchal norms in a society that nonetheless prided itself on upholding women's rights (Porvaldsdóttir, 2001). It demonstrated the paradox of women being objectified in a nation internationally recognized for a high degree of gender equality (Huijbens et al., 2012: 19-32).

This image-construction coincided with the backlash against feminist politics and policies in Iceland during the highly masculinized boom era mentioned above. It reflected a set of values that were closely associated with the influence of neoliberal ideology. Clichés about modern-day Viking territorial conquerors became household metaphors for the foreign investment drive preceding the banking collapse. Such metaphors were promoted by Icelandic businessmen and parroted by the political elite and the media (see, for example, Grímsson, 2005). One can argue that the original meaning of the word 'brand' as an attempt to mark ownership captures the essence of this exercise of patriarchal power. A brand was, after all, a piece of charred or burning wood, or a hot iron mark, that farmers used to identify their stock (see Viktorin et al., 2018: 5).

As Nigel Morgan and Annette Pritchard (1998: 217-219) have stressed, tourism is intimately related to broader societal structures - whether historical, economic, political, cultural or social. Within the Icelandic context, the image of the 'sluttish supermodel' was used to describe the status of women. Indeed, even though the branding was clearly excessive in its objectification of women and was not based on the actual position of women in Iceland, it was allowed and sustained by a degree of patriarchal attitudes in Icelandic culture. Those who created such images were, of course, products of a society that perpetuated them. As part of a nation-branding strategy, they thus sought to control and channel information and to manipulate the resulting imagery (Viktorin et al., 2018: 3). 


\section{The resurrection of the women's movement after the financial crisis}

The challenges the feminist movement faced as a result of the neoliberal turn were enormous. A group of about 30 businessmen accumulated enormous economic power, enabling them to stage what has been compared to a societal 'takeover'. These 'oligarchs' became the primary donors to political candidates and parties, bought private media companies, and made sponsorship deals with public/private education and cultural institutions (Ingimundarson, 2010). The political elite aided and abetted this process. Finance Minister and later Prime Minister Geir Haarde put it this way in 2005:

few things are more rewarding in politics than to see when a good idea becomes embedded and wins in the ideological struggle.... I am sure that no one wants to return to the time when the financial sector was subjected to political control. ${ }^{1}$

The result was the weakening of state institutions, including those that were supposed to oversee the banks.

As Cynthia Enloe (2013: 76) has pointed out, the masculinized practices that led to the banking crash suggest that, for all its success, the Icelandic feminist movement in the 1990s had not yet transformed the patriarchal internal cultures of political parties' leaderships and the country's banking establishment. Hence, it should not have come as a surprise that feminists in Iceland feared another gender backlash after the economic crisis deepened (Ólafsdóttir, 2009). They reacted by setting up what they termed a women's emergency forum in October 2008. This was an informal feminist platform, established initially as a Facebook group, whose goal was to approach the crisis through a gender lens and monitor the government response to the crisis. It was politically active for several months and highly visible in the protest movement that included broad sections of society, shaking Iceland. The international media reported regularly on the Emergency Forum, which probably influenced news stories about women taking over the political sphere. The group, however, became less visible a few months later when, in the spring of 2009, the left-wing government of Jóhanna Sigurðardóttir was formed and the group's agenda was largely taken up by the government.

The shift to the left meant that the government adopted a strategy of redistribution - with the rather surprising blessing of the International Monetary Fund (IMF), which had challenged the austerity course adopted by many other governments. Facing a massive post-crisis deficit, the Sigurðardóttir government resorted to spending cuts in healthcare and education, which hit women harder than men, especially the decision to shorten the period of paid parental leave. To cushion the blow, however, it increased welfare revenues - including unemployment benefits, housing subsidies and 
pension guarantees-for lower-income groups and reduced benefits for higherincome earners. Activation and job-creation programmes were greatly stepped up and proved very important in combatting unemployment. The tax burden of the lowest earning $60 \%$ of households was reduced (Ólafsson, 2019).

The Icelandic response to the financial crisis has gained much international attention and praise, if for different and opposing reasons. Elite international institutions, such as the IMF, came early to the conclusion that Iceland's recovery programme was a major success in economic terms and were quick to take credit for its implementation. Conversely, antiestablishment grassroots movements in Europe, such as Podemos in Spain or ATTAC in France, viewed the Icelandic political experience as a form of 'people power' as manifested in the determination to oppose the power of far stronger states and financial interests, the adoption of socially responsible policies and the decision to involve the public in writing a new constitution (Ingimundarson et al., 2016).

Iceland may have been able to stage a more successful economic comeback than most of the other European countries that were particularly badly hit, such as Greece and Portugal. What shows the societal impact of the crisis is that Iceland's surprisingly speedy economic recovery - which resulted in high growth rates, full employment and debt levels that were far lower than before the banking collapse - failed to transform, politically, into a 'new normal'. Instead, highly contested political narratives about the causes and nature of the crash or about the assignment of responsibility have emerged (Ingimundarson, 2016). Yet no backlash against women's rights has occurred, even though the number of female members of parliament dropped in the 2017 elections. On the contrary, different governments have backed gender-equality policies and used Iceland's place on the World Economic Forum's Gender Gap Index to promote Iceland on the international scene, heralding a new slant to the international branding of Iceland as a paradise of gender equality.

The spotlight, as noted earlier, has also been on the role of women in Icelandic reconstruction efforts. Under the leadership of Jóhanna Sigurðardóttir, it was claimed, women were 'cleaning up the mess' left by Icelandic men. ${ }^{2}$ Internationally, much was made of the fact that two of the three new bank directors tasked with the resurrection of the Icelandic banks were women. As it was put in one exaggerated media account: 'Women took over the country and fixed it, that's what happened' (Carlin, 2012). Similarly, when a young female TV reporter, Póra Arnórsdóttir, decided while heavily pregnant, in 2012, to run for president against the incumbent, Ólafur Ragnar Grímsson - who had been intimately tied to banking expansion but managed to cut his losses by taking sides with protesters against a deal with foreign state creditors - it was portrayed as yet another sign of women's power in Iceland and representative of its gender-equality model. To be sure, Arnórsdóttir's pregnancy generated a slew of both laudatory and sceptical reactions. On 
the one hand, it was argued that her condition showed that Iceland was in a class of its own when it came to women's rights; on the other, many questioned the young mother's 'ability' to serve as leader of a nation while simultaneously fulfilling her role as a mother. ${ }^{3}$ But, in general, her presidential run received much international coverage. After the election results were announced, her defeat was in some countries, such as France, considered more newsworthy than the victory of Ólafur Ragnar Grímsson. Indeed, one could detect a certain media disappointment. ${ }^{4}$ It reflected a typical journalistic interest in 'positive' accounts of 'female accomplishments' - suggesting that gender equality is possible. This news reporting also showed how ready and willing the international media were to participate in such fantastical constructions of gender equality in Iceland, even turning a blind eye to the fact that Icelandic opinion polls had suggested well before election day that Grímsson would win with a decisive margin.

\section{The hour of the woman: gendered national rebranding}

A major change occurred in the projection of Iceland abroad after the crash, which flew to the other extreme of the sexualized gendering that had characterized the first decade of the twenty-first century. In line with the agenda of the left-wing government, which came to power in 2009, tourism promoters in Iceland began to emphasize the country's achievements and international reputation in the field of gender equality, thereby undermining the hegemonic patriarchal discourses that sustained the paradox of image versus reality. Even while the marketing of Iceland continued to focus on nature and social recreations, such as glacier trips, whale-watching, and hot springs and natural swimming pools (notably the Blue Lagoon, a major tourist attraction), far less emphasis was put on Reykjavík nightlife, although the city was still often portrayed as being 'cool' and cosmopolitan. Overtly sexualized imagery disappeared from advertising campaigns.

In the period since the crisis erupted, one can see greater similarities between the Icelandic and the Swedish cases when viewed from the perspective of official and non-official branding efforts. There are no longer systematic efforts to market Iceland as a tourist destination on the basis of what has been termed 'gendered stereotypes in which Icelandic women are portrayed as sexually available and closely connected to Icelandic nature' (Loftsdóttir, 2015a: 255). Kristín Loftsdóttir sees some continuity in the 2010 promotion campaign 'Inspired by Iceland', which relied on an extensive collaboration between the government of Iceland, the City of Reykjavík and tourist companies. ${ }^{5}$ She argues that its use of the exotic could be read as an engagement with prior representations of Icelandic women as symbolizing untouched ('wild') nature waiting to be touched and explored. However, the 2010 campaign was, in many ways, gender-sensitive and bears no real resemblance to the previous campaigns. 
'Inspired by Iceland' was launched shortly after the banking collapse, when there was a tremendous need for strong female role models. After a 2010 volcanic eruption in Iceland made global headlines and resulted in stranded passengers around the world, the decision was taken to market Iceland as a safe and secure place, with beautiful, unspoiled nature, good food and world-class artists. This approach proved to be a major success, resulting in a sharp increase in the number of tourists visiting Iceland in the following years. The pressure for a women-friendly image projection was not only reflected in grassroots activism but also felt at the official level. The left-wing government took active steps to make women's rights a core part of its foreign policy and its branding of Iceland abroad. Thus, while Iceland's relative success in relation to gender equality during the 1980s and 1990s was not used to draw tourists to Iceland, this has changed in the last decade. Many tourists visit Iceland precisely because of its image as a socially progressive country, where security and well-being are seen as part of gender equality. It is this redrawn image that has been seized, appropriated and transmitted by the global media in its coverage of Iceland as an idealized haven of gender equality.

Iceland is commonly placed somewhere in the mythical or poetical North where the impossible is possible - where gender equality is a fact but at the same time a kind of chimera, as it is often confined to an imaginary space. The argument can be made that Icelandic women are now seen as being strong indeed, so powerful that that they are almost fantastical. The image is now differently gendered: Icelandic women are still figured as extraordinary, but their power has more to do with public influence rather than with beauty or sexuality, as had been the case in the past. Such gender constructions of women can also be seen within the context of the gender-equality imaginaries of other Nordic countries. A contemporary case in point is the international media reporting of women leading the way in response to the first wave of the COVID-19 pandemic. The seven countries that were seen as offering the most effective policies were led by women. They included four Nordic countries: Iceland, Finland, Denmark and Norway (see Wittenberg-Cox, 2020).

Yet the Icelandic paradox of image versus reality persists. While, like the other Nordic countries, Iceland has been portrayed abroad in inspirational terms when it comes to gender equality, there has been a suppression of the darker side of Icelandic gender realities and of obstacles facing women. One can also trace this trend to the coverage of the Icelandic financial crisis. In the article 'The Death of Macho', published in the journal Foreign Policy in 2009, Reihan Salam went as far as to announce the demise of masculine rule. Citing Iceland as a case in point, he maintained that voters 'threw out' the all-male elite responsible for the financial catastrophe and 'named' the lesbian Jóhanna Sigurðardóttir as their prime minister. In my critique of this article, I noted that, although inspiring, this account of a gender revolution in Iceland was idealized and premature. This was not to minimize the fact 
that the crisis exposed the bankruptcy of 'macho rule' or that a handful of Icelandic women replaced men in real power positions, but rather to point out that the male elite had not been destroyed. In 2018, when the ten-year anniversary of the crash was remembered in Iceland, the 'old boys' network was still alive and clinging to power. Its continued presence was shown by the fall of two Icelandic governments - one over the Panama Papers scandal and the other over accusations of a political cover-up in connection with the government handling of a child abuse case - in 2016 and 2017, respectively.

As I have stressed here, there has been a clear shift towards gender equality in Icelandic national branding, which is sponsored officially by Promote Iceland, the official tourist board, in cooperation with private companies. Such branding has moved away from the sexualized female object to the image of a powerful woman leader. Being 'first' in some capacity is a major part of this portrayal - whether as the first elected women president, the first lesbian prime minister or the youngest female prime minister (see also Jezierska and Towns, this volume; Larsen, this volume). On the other hand, it is rarely made explicit that all these leaders came to power following a major crisis, as was the case with Prime Minster Jóhanna Sigurðardóttir, who had to deal with the biggest financial crisis since the founding of the Icelandic Republic in 1944, and with Prime Minister Katrín Jakobsdóttir, who took office in December 2017 after the collapse of the third male-led centreright government that lost the confidence of the Icelandic population before serving out its full term. Regardless of the fact that these women came to power under disturbed circumstances, their role as leaders strengthens the image of women in power, successfully lending itself to this form of nationbranding, as both male and female politicians have realized.

\section{Creating the 'equal rights paradise'}

The relationship between Iceland's positive branding of itself and the international media's affirmation and creation of this brand is significant because such image-making seeks to stimulate a desire to own the 'product' by way of consumption (Viktorin et al., 2018). Iceland's reputation has capitalized on a broader representation of the classic Nordic societal model, in which a market economy is combined with a strong welfare state based on gender equality. Nordic governments, which work closely together in international organizations, have been eager to maintain and promote this profile. For decades, the Nordic Council of Ministers has projected the image of 'world leadership in gender equality'. ${ }^{6}$ Celebratory news stories ${ }^{7}$ about Iceland's top ranking on the World Economic Forum's index for 11 consecutive years have given the impression that gender-equality processes are linear and straightforward and that they can be easily be measured. Yet the index is more about gender gaps than about levels of gender equality (see Rúdólfsdóttir, 2014). The desire to 'own' a product through consumption, however, has kept the image of Iceland as a paragon of gender equality alive and unblemished. Thus, Iceland is considered to have the smallest gender 
gap, which has sometimes been erroneously interpreted as meaning that it has achieved full equality.

Apart from female government and parliamentary participation, a key World Economic Forum index measures the number of years women have exerted political power by focusing on their ratio in government and parliament. Also taken into special consideration is the number of years, in the past half a century, that women have served as heads of state. Since Vigdís Finnbogadóttir served four consecutive four-year terms as the president of Iceland - from 1980 to 1996 - this partly explains Iceland's high score on the list - together with Jóhanna Sigurðardóttir's term as prime minister from 2009 to 2013 and that of the current prime minister, Katrín Jakobsdóttir, who has been in office since 2017. Moreover, the measurement scale on which the World Economic Forum survey is based also uses simple explanatory variables that do not show the whole picture. They do not, notably, include weak points, such as the persistent degree of gender segregation in the labour market, violence against women, or the uneven sharing of responsibilities for the upbringing of children or the care of the elderly. These factors are overlooked despite the fact that they have a great impact on gender equality in the labour market and women's chances of gaining more economic or political power. ${ }^{8}$ While Icelandic feminists have consistently sought to correct such misconceptions, foreign media reports tend to gloss over the persistence of domestic violence and gender pay gaps in Iceland. ${ }^{9}$

Awareness of these inequalities, however, should not deflect from acknowledging the enormous efforts made by Icelandic feminists in the last decade to use a more progressive political climate to push through greater gender-equality measures. Historically influenced by several factors such as equality laws in other Nordic countries, international agreements and, more recently, European Union/European Economic Area legislation, Icelandic gender-equality legislation is now being given a wider social role as part of an intersectionalist approach. Its agenda has widened to include groups such as the LGBTQI+ community, which has led to the introduction of affirmative-action programmes and legislative measures mandating the public sector to fight gender inequality and discrimination. ${ }^{10}$ The status of non-state actors, including enterprises and NGOs, such as the National Queer Association of Iceland, has also been strengthened by law and government contracts in recent years. ${ }^{11}$ Earlier, the prevailing opinion was that women were to seek education and establish themselves in the lower strata of society and work upwards from there to positions of greater influence and power. This opinion was consistent with liberal ideas that were predominant in other Nordic countries in general. It echoed the traditional liberal ideology based on the presumption that giving women equal legal rights was sufficient for the position of women vis-à-vis men to improve in due course until full equality would be reached.

While in the other Nordic countries there has been a steady rise in women's representation, in Iceland changes only seem to occur when there is a major systemic challenge in politics or the economy. Icelandic political 
scientist Auður Styrkársdóttir (2012) has aptly compared waves of women's democratic enfranchisements throughout the twentieth century with natural upheavals, such as earthquakes or volcanoes (see also Erlingsdóttir, 2011). The financial crisis proved to be one such seminal moment. In the 2009 parliamentary elections, the number of women members of parliament rose from $32 \%$ to $43 \%$. These results were also reflected in municipal elections the following year, where the levels of women reached $40 \%$. Never before had women been better represented at the national and local levels in Icelandic politics. When the left-wing government was formed in 2009 , gender parity was achieved for the first time, with women holding an equal number of government posts as men. Many saw this as a culmination of feminist activism dating back to the 1980s, when the Women's Alliance played an instrumental role in boosting women's representation in parliament and other political institutions.

The increased participation of women in Icelandic politics has, historically, been based on the women's movement for equal rights and representation. This movement was evident in the 2009 government, which identified itself with feminist ideology, highlighting equality and women's liberation in its manifesto. ${ }^{12}$ Soon after assuming power, it pushed several laws through parliament that had been on the agenda of the Icelandic women's movement. The changes included making paying for sex illegal as in the Swedish model, banning strip clubs - making Iceland the first country to do so on gender grounds rather than religious ones - and imposing a gender quota system on the boards of both private and state-owned major companies. The government also initiated work on an Equal Pay Standard, which was published in 2012 and served as a basis for a 2018 law on equal-pay certification. This law made Iceland the first country in the world to require companies with 25 or more employees to obtain official certification to prove they offer equal pay for work of equal value regardless of gender. ${ }^{13}$ The same year, legislation on the equal treatment of individuals irrespective of race, ethnic origin, religion, life stance, disability, reduced working capacity, age, sexual orientation, gender identity, sexual characteristics or gender expression was passed.

Interestingly, the policies adopted in 2009 have been expanded by successive governments, which have included right-wing parties with a history of opposing affirmative-action programmes. While the left has historically been responsible for developing such policies, all the established parties, including the moderate right, have taken part in implementing them. To be sure, some conservative and populist political forces have been far less supportive of policies such as the liberalization of abortion rights, but there has been no backlash over them. This shows that there is a cross-political consensus on the promotion of the gender-equality model, which, in turn, has been seen in conjunction with Iceland's post-crisis rebranding efforts. Combined with the ongoing efforts of feminist organizations in the country, the agenda of gender equality is now firmly entrenched in the political matrix. Thus, in 2019, Iceland passed legislation on trans and intersex rights 
without any public conflict (Fisher, 2019). The same year, the parliament passed a bill on abortion, repealing the previous Act on Abortion dating back to 1975. The new law codifies women's personal autonomy and selfdetermination over their own bodies and legalizes the termination of a pregnancy within the first 22 weeks regardless of circumstances. ${ }^{14}$

Finally, as an example of the influence of Icelandic feminist activism abroad, two additional developments can be mentioned: First, the women's strike in 1975 (also called 'Women's Day Off'), which brought the country to a standstill, recently served as a historical model both in Iceland and internationally. While the strike has been repeated five times in Iceland - in 1985, 2005, 2010, 2016 and 2018 - it was used as a reference point in Poland in 2016, when thousands of women went on strike in protest against proposals for a total ban on abortions. ${ }^{15}$ The initiative inspired women's and feminist organizations in Argentina, including the Ni Una Menos collective, to organize a one-hour strike and mass mobilizations that were replicated in most countries of Latin America and the Caribbean (James, 2018). This cascade inspired by the Icelandic model led to a global movement with the first International Women's Strike taking place in more than 50 countries on 8 March 2017 (Topping and Redden, 2017). Second, the Women's Alliance has been tied to political empowerment of women not only in Iceland but also in other countries (Schneier, 1992). More than 30 women's parties have been established on the national or municipal levels since 1987 (Evans and Kenny, 2019). Until the early 1980s, the participation of women in Icelandic politics had been very low, with women comprising only about $2 \%-5 \%$ of parliamentarians and being mostly excluded from traditional political parties. The Women's Alliance's entry into parliament led to major changes with respect to female political representation.

Thus, what has made Iceland so visible in the area of gender equality internationally is that it has been able to integrate the image of the Nordic welfare state with specific feminist actions in the past as part of a successful crisis response in the present. While this branding has both been intentional and unintentional, it has served to enhance the country's profile and reputation management abroad.

\section{The elevation of gender equality in Iceland's foreign policy}

Given the intense pressure facing the Icelandic government abroad in the wake of the financial crisis, it realized it had to make sustained efforts to improve its image in a field where it could show credibility. Needless to say, this led to the abandonment of the disastrous masculine nation-branding strategy - as articulated by politicians, businessmen and the media - based on the 'successes' of the Icelandic banking expansion (Prime Minister's Office, Iceland, 2008). Instead, gender equality was made a core issue in Icelandic foreign policy (Cull, 2016: 156). While it is true that gender equality had already become part of Iceland's international development cooperation in 
2007, when a feminist foreign minister, Ingibjörg Sólrún Gísladóttir, put women's empowerment on the agenda, it was not yet firmly embedded. Gísladóttir, a former member of parliament for the Women's Alliance, was at that time the leader of the Social Democratic Alliance, which formed a coalition government with the conservative Independence Party from 2007 to 2009. This government was brought down by the financial crisis. The piecemeal inclusion of gender issues in government policy by Gísladóttir was a direct legacy of the Women's Alliance. Even if the women's movements and feminist ideologies had a fundamental impact on Icelandic society in the twentieth century, they were hardly reflected in Iceland's realistoriented foreign policy based on its military ties with the United States and NATO during and after the Cold War. Iceland's international image and interaction with other nations, in other words, did not include issues of gender equality. After the crash, however, things began to change. There was a significant increase in the number of women in the foreign ministry and among ambassadors, and even the influence of the peace agenda of the Women's Alliance, which had been ignored in Iceland's foreign policy in the 1980s and 1990s, can be detected after 2009 (Ómarsdóttir, 2010).

Thus, gender equality has been prioritized in Iceland's foreign policy thanks in large part to feminists inside and outside political parties who have put pressure on the government (Ómarsdóttir, 2010). Among further measures taken was the establishment in 2009 of a United Nations Gender Equality Studies and Training Programme (GEST) - funded by the Icelandic Foreign Ministry and targeted at students from developing and postconflict countries - at the University of Iceland. ${ }^{16}$ Gender-equality expertise has often been presented as a Nordic export commodity. EU countries Sweden, Finland and Denmark have mostly focused on influencing other EU member-states, while Norway and Iceland's aim has been to promote gender equality in developing and post-conflict countries. The GEST programme ${ }^{17}$ was promoted by academics on the grounds that if Iceland was to sponsor development projects in the geothermal, fisheries and land-restoration fields - where its performance had been noted abroad - gender equality was another area where Iceland could play a role and take on international responsibility. GEST thus owes its very existence and funding to the fact that it is seen as playing up the strengths of Iceland in the field of gender equality, and it is an integral part of Iceland's development policy and peacebuilding agenda. Its mission and academic aim is to engage in a critical debate about equality, not to impose standards or policies for women's empowerment on developing countries. The driving force behind the project is a critical, even radical, feminist stance on development and international politics. This means that its content does not always harmonize with the Foreign Ministry's broader national-branding agenda or political interests, even if it reflects the goal of promoting gender equality. Yet, being at the same time part of Iceland's governmental efforts, it is sometimes challenged by official ideas about nation-branding and feminism in its neoliberal form. 
Another part of Iceland's foreign policy and gender strategy includes political and financial support for UN Women, and, recently, it has extended its agenda to addressing discriminatory stereotypes of masculinity and engaging men and boys for gender equality. Towards this effort, the Ministry for Foreign Affairs has organized so-called Barbershop discussions around the world, which are consistent with Iceland's participation in the HeForShe campaign. The Barbershop concept was developed jointly by the Permanent UN Missions of Iceland and Suriname (countries ranked best and worst in the World Economic Forum's 2013 report) within the context of the 20th anniversary of the Beijing Declaration and Platform for Action in 2015. The purpose was to bring men to the table as partners for gender equality, encouraging them to look at their own attitudes and behaviour. Several Barbershop conferences have been held, including at the UN, the Nordic Council of Ministers, NATO, the Council of Europe, the Icelandic parliament and the Icelandic Ministry for Foreign Affairs. ${ }^{18}$ While they were envisaged as a discussion platform for men, they have always been open to women (United Nations, 2015).

To be sure, the initiative has not been without criticism. According to Dyan Mazurana, who contributed to the 2002 Women, Peace and Security report for the UN Security Council, women 'don't want to be spoken for, we'd like to speak for ourselves'. She also noted that the UN 'has a long and disgraceful history of men-only meetings on issues that are foundational to the rights of women' (Tulinius, 2014). The idea was, however, welcomed by others, such as Gary Barker, who works for Promundo, a Brazilian organization that aims to enlist men in the struggle for gender equality on the grounds that it was not meant to replicate 'smoke-filled rooms' but to create a safe space for male political leaders to talk about ways to engage men in the ongoing efforts to reduce violence against women (Tulinius, 2014). The idea can, in fact, be attributed to former Icelandic President Vigdís Finnbogadóttir, who had for many years appealed for ways to include men in the gender-equality debate. The idea was subsequently developed further by feminists within the Icelandic Foreign Ministry, who wanted to experiment with it at the United Nations. Foreign Minister Gunnar Bragi Sveinsson decided to organize and campaign for the Barbershop conference there in 2015. In a disastrous instance of the paradox of gender equality existing within and alongside patriarchal behaviour, Sveinsson's mandate was tainted by his role in a political scandal with highly gendered dimensions in 2018. He was among a few male parliamentarians and one woman member of parliament caught on tape demeaning, in a highly misogynistic way, their female parliamentary colleagues. Thus, while Mazurana's criticism of male-dominated meetings was not directed at Sveinsson personally, it conveyed an eerie sense of premonition. It underlined the need for a systemic rooting out of patriarchal misogyny from society if the image and aspiration of gender equality was to become reality (Grettisson, 2018). 
On the international stage, however, Iceland continued to play its part in furthering the agenda of gender equality. Elected to the UN Human Rights Council following the withdrawal of the United States from the body in June 2018, it focused in particular on women's rights and gender equality, LGBTQI+ rights, and the rights of the child. Another initiative that fed into the international view of the equality brand was the annual Reykjavík Women Leaders Global Forum, ${ }^{19}$ which was launched in 2017 with the participation of women leaders from all over the world. It has now been organized three years in a row in Iceland with a growing number of participants. Here, far removed from its earlier branding as the dirty-weekend capital, Reykjavík has been rebranded as a platform where women leaders share ideas on how to further advance society with explicit references to Iceland's place on the World Economic Forum's Gender Gap Index and to past and present Icelandic female leaders. Former President Vigdís Finnbogdóttir is internationally praised for her part in paving the way for women's political leaders; former Prime Minister Jóhanna Sigurðardóttir played a key role in the post-crash reconstruction efforts and became globally known as the first openly lesbian prime minister when the international media got wind of her sexual orientation. In Iceland, however, her sexuality was never made an issue or considered worthy of any media exposure. In continuance of this legacy, the current prime minister, Katrín Jakobsdóttir, accepted in February 2020 the appointment to the chair of the Council of Women World Leaders, an organization established by Finnbogadóttir in 1996 (Government of Iceland, 2020a). And, in line with the government promotion of gender equality, in Iceland and abroad, the competency for this policy area was transferred from the auspices of the Ministry of Welfare to the Prime Minister's Office in January 2019. ${ }^{20}$

In spite of all its prominence in terms of gender equality on the international stage, one should not exaggerate the influence of a small country like Iceland on the gender-equality policies of other countries. However, its stature is enhanced in association with other Nordic countries with which it shares a reputation as a 'norm entrepreneur' in the field of gender equality (Ingebritsen, 2002). Iceland's credibility is also enhanced by its consistent support for gender equality since 2009, irrespective of whether governments have been led by the left or right. In this sense, as I have argued here, gender equality and state-supported feminism have become part of both a national aspiration and a national branding strategy that seems to work well for Iceland on the level of foreign policy and business.

\section{Conclusion}

While adhering to international notions of altruistic Nordic 'exceptionalism', Nordic gender-equality branding has also much to do with Realpolitik or with what Louis Clerc and Nikolas Glover (2015: 12) have termed 'the necessity for small states to act in character'. This applies to Iceland's nation-branding with respect to gender equality, which was about creating 
an image or a product to negotiate an emotional relationship between brand owners and prospective customers to repair its reputation abroad (Viktorin et al., 2018: 4). It points to the inherent tension in such politicized marketing projects - with self-interested state and corporatist practices often being conflated with idealistic motivations for social change and partnerships with civil society (Viktorin et al., 2018: 11). Since Iceland has by no means achieved gender parity, such image-making not only can adversely affect the struggle for women's rights and help 'normalize' gender discrimination but can also reinforce the notion that a state of perfection has been reached. In other words, the Icelandic gender-equality imaginary risks being appropriated and redefined by the state, which is as much concerned with elevating Iceland as a national brand driven by market motives. The lack of any critical engagements with the measurement flaws inherent in gender-gap indices or the persistence of gender inequalities in Icelandic society undermines the official message about Icelandic 'exceptionalism'.

This is not to say that nothing has been achieved. Exoticism, with its many problematic gender connotations, has continued to dominate the marketing strategies of the Icelandic tourist industry. But, in contrast to the first decade of the twenty-first century, Icelandic companies have, as I have stressed, moved away from the objectification and sexualization of women. What is more, the branding of equality made it possible to access positive memories of past feminist successes as well as to overcome the stigma associated with the Viking business expansion and its masculine-driven excesses. It is true that Icelandic policies on gender cannot be separated from what can be termed symbolic politics. Successive governments continue to issue universal proclamations on gender equality even if they pay little attention to minorities, such as immigrants, and provide inadequate financial resources to develop and finance policy decisions. Nonetheless, the Icelandic Foreign Ministry and the tourist industry have managed to capitalize on Iceland's gender-equality record in government-supported nation-branding campaigns. That this image fits with pre-existing, traditional ones of Iceland as being progressive on women's rights also explains why state representatives harp on the issue, for they know that it resonates among foreign publics (Clerc and Glover, 2015: 12). Such attitudes only confirm that strategies of nation-branding are less about mutual understanding among nations and more about image management by publicly touting positive 'national characteristics'. However, as the Icelandic experience in the past decade shows, they can also be used effectively to further an agenda of gender equality, even while rescuing the national brand of a small state that was in acute danger of permanent damage.

\section{Notes}

1 Geir H. Haarde, 'Address on the Occasion of the SBV Day', 7 April 2005, cited in Sigfúsdóttir (2011: 1).

2 See, for example, Gros (2012a); Ertel (2009); O’Connor (2008); Sunderland (2009). 
3 See BBC News (2012a, 2012b); Chocas (2012); Gros (2012b); Chabas (2012a); Jonanin (2012); McVeigh (2012); Grontoft (2012).

4 See, for example, Chabas (2012b); Gros (2012c).

5 See https://www.inspiredbyiceland.com (accessed 19 April 2020).

6 See Prime Minister's Office, Iceland (2019).

7 See, for example, Economist (2018); Hertz (2016); Pelaez (2018); Women Political Leaders (2014); BBC News (2010); Noman (2015); Johnson (2011).

8 The World Economic Forum's Gender Gap Index ranks countries according to a calculated gender gap between women and men in only four areas: health, education, economy and politics. For more detailed information about the status of gender equality in Iceland, see Icelandic Human Rights Centre and Icelandic Women's Rights Association (2016); Prime Minister's Office, Iceland (2019).

9 There are exceptions, though; see Domonoske (2018); Independent (2017).

10 The most-effective affirmative action being the comprehensive law on parental leave that came into effect in 2000 (see Arnalds et al., 2013). In June 2018, the Icelandic parliament approved a law banning, among other things, employment discrimination based on sexual orientation, gender identity, gender expression and sex characteristics. The law, known as the Law on Equal Treatment in the Workplace, took effect on 1 September 2018. In June 2019, the parliament enacted a law on the self-determination of gender change, which is consistent with similar laws adopted in numerous European and South American countries. The new law allows transgender individuals to change their legal gender without having to receive a medical and mental disorder diagnosis or undergo sterilization and sex-reassignment surgery. Minors may also change their legal gender with parental consent. Furthermore, the law allows individuals to choose a third gender option known as ' $\mathrm{X}$ ' on official documents.

11 See the Agreement between the Prime Minister's Office and the National Queer Organisation, February 2019 (Stjórnarráo Íslands, 2019a); Agreement between the Icelandic Women's Rights Association and the Prime Minister's Office, June 2019 (Stjórnarráð Íslands, 2019b).

12 See the Government Declaration of the Social Democratic Alliance and the Left Green Movement from 2009 (Stjórnarráð Íslands, 2009).

13 See Government of Iceland (2014).

14 The new legislation codifies the personal autonomy and self-determination women have over their own bodies and guarantees the right to healthcare in relation to abortion on demand up until the end of the 22nd week of pregnancy. See Fontaine (2019); International Campaign for Women's Rights to Safe Abortion (2019).

15 Gosia Wochowska of Gals4Gals Lodz stated that 'Icelandic women gave us inspiration to organize ourselves in defense of women's rights in Poland in the recent years, and therefore now we would like to offer them our support in turn'. Elena Pontil from the Italian Non Una Di Meno was also quoted as saying that 'none of European countries is free from gender earnings gaps, and Iceland already has one of the lowest gender earnings gaps in the world. So we believe that this is actually a great opportunity to highlight the problem in our countries too'; see Kvenréttindafélag Íslands (2018). See also Suchanow (2020).

16 Guðlaugur Pór Pórðarson, Iceland's minister for foreign affairs, has stressed that the Gender Equality Studies and Training Programme (UNU-GEST) reflects Iceland's strong emphasis on gender equality in its international development work; see Government of Iceland (2020b).

17 On the GEST programme, see www.gest.org (accessed 19 April 2020).

18 The National Committee and the Ministry for Foreign Affairs developed a Barbershop toolbox to make the Barbershop available to all HeForShes who want 
to engage men and boys in their communities, workplaces, schools or elsewhere; see http://www.heforshe.org/en/barbershop (accessed 19 April 2020).

19 On the Reykjavik Women Leaders Global Forum, see its website at https:// reykjavikforum.global.

20 It is now the role of the Prime Minister's Office to enforce the Gender Equality and Anti-Discrimination Acts as well as to administrate the overall governmental coordination. The aim is to advance policy-making on gender equality and mainstreaming of polices and decision in all lines of ministries and state institutions.

\section{References}

Arnalds ÁA, Eydal GB and Gíslason IV (2013) Equal rights to paid parental leave and caring fathers: The case of Iceland. Icelandic Review of Politics and Administration 9(2): 323-344.

BBC News (2010) Iceland best country for gender equality. 12 October. Available at: https://www.bbc.com/news/business-11517459 (accessed 19 April 2020).

BBC News (2012a) Meet the Icelandic mother hoping to be president. 29 June. Available at: https://www.bbc.com/news/av/world-europe-18655735/meet-theicelandic-mother-hoping-to-be-president (accessed 19 April 2020).

BBC News (2012b) On the campaign trail nappies in hand. 29 June. Available at: https://www.bbc.com/news/av/world-18638878/on-the-campaign-trail-nappies-inhand (accessed 19 April 2020).

Carlin J (2012) A Nordic revolution: The heroines of Reykjavik. Independent, 21 April. Available at: https://www.independent.co.uk/news/world/europe/a-nordicrevolution-the-heroines-of-reykjavik-7658212.html (accessed 18 April 2020).

Chabas C (2012a) Journaliste vedette et jeune maman, Thora veut rendre confiance à l'Islande. Le Monde, 29 June. Available at: https://www.lemonde.fr/europe/ article/2012/06/29/journaliste-vedette-et-jeune-maman-thora-veut-rendreconfiance-a-1-islande_1727041_3214.html (accessed 19 April 2020).

Chabas C (2012b) Islande. Vingt ans de présidence pour Olafur. Le Monde, 1 July. Available at: https://www.lemonde.fr/europe/article/2012/07/01/islande-vingt-ansde-presidence-pour-olafur_1727515_3214.h (accessed 19 April 2020).

Chocas V (2012) Thora, mère d'Islande. Le Figaro, 25 June. Available at: https:// madame.lefigaro.fr/societe/thora-mere-dislande-250612-232853 (accessed 19 April 2020).

Clerc L and Glover N (2015) Representing the small states of Northern Europe: Between imagined and imaged communities. In: Clerc L, Glover N and Jordan P (eds) Histories of Public Diplomacy and Nation Branding in the Nordic and Baltic Countries: Representing the Periphery. Leiden: Brill-Nijhoff, 3-20.

Connell RW (1998) Masculinities and globalization. Men and Masculinities 1(1): $3-23$.

Cull NJ (2016) A region speaks: Nordic public diplomacy in historical context. Place Branding and Public Diplomacy 12(2-3): 152-159.

Domonoske C (2018) Companies in Iceland now required to demonstrate they pay men, women fairly. NPR, 3 January. Available at: https://www.npr.org/sections/ thetwo-way/2018/01/03/575403863/companies-in-iceland-now-required-todemonstrate-they-pay-men-women-fairly?t=1587214743795 (accessed 17 April 2010). 
Economist (2018) The best place to be a woman? 19 December. Available at: https:// www.youtube.com/watch?v=17fyqpHKARg (accessed 19 April 2020).

Enloe C (2013) Vikings and the smartest guys: Masculinities in the banking crash. In: Enloe C, Seriously! Investigating Crashes and Crises as if Women Mattered. Berkeley \& Los Angeles: University of California Press, 49-85.

Enloe C (2017) The Big Push: Exposing and Challenging the Persistence of Patriarchy. Oakland: University of California Press.

Erlingsdóttir R (2011) Kynbundin valdakerfi í stjórnmálum. Published on the resource page of the Icelandic Directorate of Equality. Available at: https://www. jafnretti.is/is/um-jafnrettisstofu/greinar/kynbundin-valdakerfi-i-stornmalum (accessed 19 April 2020).

Ertel M (2009) Cleaning up the men's mess: Iceland's women reach for power. Spiegel International, 22 April. Available at: https://www.spiegel.de/international/europe/ cleaning-up-the-men-s-mess-iceland-s-women-reach-for-power-a-620544.html (accessed 18 April 2020).

Evans E and Kenny M (2019) The Women's Equality Party: Emergence, organisation and challenges. Political Studies 67(4): 855-871.

Fisher O (2019) On trans issues, Iceland has just put Britain to shame. Guardian, 21 June. Available at: https://www.theguardian.com/commentisfree/2019/jun/21/ trans-issues-britain-iceland-law-intersex-rights (accessed 22 February 2020).

Fontaine A (2019) Iceland passes landmark abortion law. Reykjavík Grapevine, 14 May. Available at: https:/grapevine.is/news/2019/05/14/icelands-parliamentpasses-landmark-abortion-law (accessed 19 April 2020).

Government of Iceland (2014) Equal pay certification. Available at: https://www. government.is/topics/human-rights-and-equality/equal-pay-certification (accessed 14 April 2020).

Government of Iceland (2020a) Katrín Jakobsdóttir, prime minister of Iceland is chair of the Council of Women World Leaders. Available at: https:// www.government.is/ministries/prime-ministers-office/chairmanship-in-thecouncil-of-women-world-leaders/katrin-jakobsdottir-prime-minister-of-iceland (accessed 20 April 2020).

Government of Iceland (2020b) Iceland remains the top country on the World Economic Forum's Index for Gender Parity. 18 December. Available at: https://www. government.is/diplomatic-missions/embassy-article/2019/12/18/Iceland-remainsthe-top-country-on-the-World-Economic-Forums-index-for-gender-parity/ (accessed 18 April 2020).

Grettisson V (2018) The architect for the Barbershop-Conference openly misogynist. Reykjavik Grapevine, 29 November. Available at: https:/grapevine.is/ news/2018/11/29/the-architect-for-the-barbershop-conference-openly-misogynist/ ?steady_tried_to_set_safari_fix_cookie (accessed 19 April 2020).

Grímsson ÓR (2005) How to succeed in modern business: Lessons from the Icelandic voyage. Speech by the President of Iceland at the Walbrook Club, London, 3 May 2005. Available at: https://grapevine.is/mag/articles/2008/10/10/how-tosucceed-in-modern-business-olafur-ragnar-grimsson-at-the-walbrook-club/ (accessed 6 August 2020).

Grontoft K (2012) Thora Arnorsdottir (37) er nybakt mor og presidentkandidat. Aftenposten, 11 June. Available at: https://www.aftenposten.no/norge/i/awe0M/thoraarnorsdottir-37-er-nybakt-mor-og-presidentkandidat (accessed 19 April 2020). 
Gros M-J (2012a) L'Islande tout feu tout femmes. Libération, 24 April. Available at: https://www.liberation.fr/planete/2012/04/24/1-islande-tout-feu-tout-femmes 814073 (accessed 19 April 2020).

Gros M-J (2012b) Thora Arnorsdottir: Couches populaires. Libération, 14 June. Available at: https://www.liberation.fr/planete/2012/06/14/thora-arnorsdottircouches-populaires_826376 (accessed 19 April 2020).

Gros M-J (2012c) Olafur Ragnar Grimsson elu president pour la cinquème fois. Liberation, 1 July. Available at: https://www.liberation.fr/planete/2012/07/01/olafurragnar-grimsson-elu-president-pour-la-cinquieme-fois_830381 (accessed 19 April 2020).

Hertz N (2016) Why Iceland is the best place to be a woman. Guardian, 26 October. Available at: https://www.theguardian.com/lifeandstyle/2016/oct/24/iceland-bestplace-to-be-women-equal-gender-maternity (accessed 19 April 2020).

Huijbens E, Alessio D, Margaryan L and Jóhannsdóttir AL (2012) Birtingarmyndir kyngervis og pversagnir í markaðsefni íslenskrar ferðapjónustu. Íslenska pjóðfélagið 3: 19-39.

Icelandic Human Rights Centre and Icelandic Women's Rights Association (2016) Icelandic Shadow Report for CEDAW. Available at: http://kvenrettindafelag.is/ wp-content/uploads/2016/02/skuggaskyrsla_web.pdf (accessed 19 April 2020).

Icelandic Tourist Board (2005) Könnun Ferðamálaráðs Íslands meðal erlendra ferðamanna. Niðurstöður fyrir timabilið september 2004-maí 2005. Available at: https://www.ferdamalastofa.is/static/files/konn_vetur0405_vefur/index.html (accessed 19 April 2020).

Independent (2017) Gender equality leader Iceland criticized over sexual abuse statistics. 12 December. Available at: https://www.independent.ie/world-news/genderequality-leader-iceland-criticised-over-sexual-abuse-statistics-36401282.html (accessed 17 April 2020).

Ingebritsen C (2002) Norm entrepreneurs: Scandinavia's role in world politics. Cooperation and Conflict 37(1): 11-23.

Ingimundarson V (2010) A 'crisis of affluence': The politics of an economic breakdown in Iceland. Irish Studies in International Affairs 21: 57-63.

Ingimundarson V (2016) The politics of transition, memory and justice: Assigning blame for the Icelandic crisis. In: Ingimundarson V, Erlingsdóttir I and Urfalino P (eds) Iceland's Financial Crisis. London: Routledge, 140-155.

Ingimundarson V, Erlingsdóttir I and Urfalino P (2016) Introduction. In: Ingimundarson V, Erlingsdóttir I and Urfalino P (eds) Iceland's Financial Crisis. London: Routledge, 1-18.

International Campaign for Women's Rights to Safe Abortion (2019) Iceland An already liberal abortion law further reformed: 'Ready for the 21st century'. 17 May. Available at: https://www.safeabortionwomensright.org/icelandan-already-liberal-abortion-law-further-reformed-ready-for-the-21s (accessed 17 April 2020).

James S (2018) Decades after Iceland's 'day off', our women's strike is stronger than ever. Guardian, 8 March. Available at: https://www.theguardian.com/commentisfree/2018/ mar/08/iceland-global-womens-strike-protest (accessed 19 April 2020).

Jezierska K and Towns A (2021) Variations on shared themes: Branding the Nordics as gender-equal. In: Larsen E, Moss SM and Skjelsbæk I (eds) Gender Equality and Nation-Branding in the Nordic Region. Abingdon: Routledge. 
Johnson JE (2011) The most feminist place in the world. Nation, 3 February. Available at: https://www.thenation.com/article/most-feminist-place-world/ (accessed 16 February 2020).

Johnson JE (2018) The Gender of Informal Politics: Russia, Iceland and TwentyCentury Male Dominance. Basingstoke: Palgrave McMillan.

Jonanin P (2012) Journalist Thora Arnorsdottir is the favourite in the Icelandic presidential election, to be held on 30th June. Foundation Robert Schuman: The European Elections Monitor, May. Available at: https://www.robert-schuman. eu/en/eem/1313-journalist-thora-arnorsdottir-is-the-favourite-in-the-icelandicpresidential-election-to-be-held-on-30th-june (accessed 19 April 2020).

Kvenréttindafélag Íslands (2018) Iceland's women's strike on a European level. 22 October. Available at: https://kvenrettindafelag.is/2018/icelandic-womens-strikeon-a-european-level (accessed 27 July 2020).

Larsen E (2021) 'The gender-progressive Nordics': A matter of history. In: Larsen E, Moss SM and Skjelsbæk I (eds) Gender Equality and Nation-Branding in the Nordic Region. Abingdon: Routledge, 13-38.

Loftsdóttir K (2015a) The exotic North: Gender, nation branding and postcolonialism in Iceland. NORA - Nordic Journal of Feminist and Gender Research 23(4): 246-260.

Loftsdóttir K (2015b) Vikings invade present-day Iceland. In: Durrenberger EP and Pálsson G (eds) Gambling Debt: Iceland's Rise and Fall in the Global Economy. Boulder: University Press of Colorado, 3-14.

McVeigh T (2012) She's young, blonde, polite and doesn't do party politics: Just the guy for president. Guardian, 23 June. Available at: https://www.theguardian.com/ world/2012/jun/23/iceland-europe-news (accessed 19 April 2020).

Morgan N and Pritchard A (1998) 'Mood marketing' - The new destination branding strategy: A case study of 'Wales' the brand. Journal of Vacation Marketing 4(3): 215-229.

Noman N (2015) What Iceland did to become the most feminist country in the world. Mic, 13 August. Available at: https://www.mic.com/articles/114962/here-s-howiceland-became-the-most-feminist-country-in-the-world (accessed 19 April 2020).

O'Connor S (2008) Icelandic women to clean up 'male mess'. Financial Times, 13 October. Available at: https://www.ft.com/content/c347a766-994b-11dd-9d48000077 b07658 (accessed 18 April 2020).

Ólafsdóttir K (2009) Gender effects of the economic crisis. In: Hannibalsson I (ed.) Rannsóknir i félagsvísindum X. Viðskipta- og hagfraðideild. Reykjavík: Félagsvísindastofnun Háskóla Íslands, 343-352.

Ólafsson S (2019) Iceland's strategy of redistribution. In: Ólafsson S, Daly M, Kangas $\mathrm{O}$ and Palme $\mathrm{J}$ (eds) Welfare and the Great Recession: A Comparative Study. Oxford: Oxford University Press, 132-153.

Ómarsdóttir SB (2010) Áhrif femínisma á utanríkisstefnu Íslands 1999-2009. Stjórnmál og stjórnsýsla 6(1): 73-94.

Pelaez MW (2018) Is female-friendly Iceland a gender equality paradise? Globe Post, 15 February. Available at: https://theglobepost.com/2018/02/15/iceland-genderequality/ (accessed 27 July 2020).

Prime Minister's Office, Iceland (2008) Ímynd Íslands: Styrkur, staða og stefna. Reykjavík. Available at: https://www.ferdamalastofa.is/is/tolur-og-utgafur/utgefidefni/imynd-og-markadsmal/imynd-islands (accessed 16 February 2020). 
Prime Minister's Office, Iceland (2019) Iceland's Report on Beijing +25 . Available at: https://www.unece.org/fileadmin/DAM/RCM_Website/Iceland.pdf (accessed 19 April 2020).

Rúdólfsdóttir G (2014) Iceland is great for women, but it's no feminist paradise. Guardian, 28 October. Available at: https://www.theguardian.com/ commentisfree/2014/oct/28/iceland-women-feminist-paradise-gender-gap-pay (accessed 19 April 2020).

Salam R (2009) The death of macho. Foreign Policy, 21 June. Available at: https:// foreignpolicy.com/2009/06/21/the-death-of-macho (accessed 27 July 2020).

Schneier E (1992) Icelandic women at the brink of power. Scandinavian Studies 64(3): 417-438.

Sigfúsdóttir VP (2011) Réttarstaða ráðherra sem sakborninga fyrir Landsómi í ljósi stjórnarskrár lýðveldisins Íslands og Mannréttindasáttmála Evrópu. ML thesis in law, University of Bifröst.

Styrkársdóttir A (2012) Breaking male dominance by extraordinary means. In: Dahlerup D and Leyenaar M (eds) Breaking Male Dominance in Old Democracies. Oxford: Oxford Scholarship, 88-96.

Stjórnarráð Íslands (2009) Samstarfsyfirlýsing ríkisstjórnar: Samfylkingarinnar og Vinstrihreyfingarinnar - græns framboðs. 8 May. Available at: https://www.mbl. is/greinasafn/grein/1282359/ (accessed 22 February 2020).

Stjórnarráð Íslands (2019a) Forsætisráðherra undirritar samning við Samtökin '78. 2 February. Available at: https://www.stjornarradid.is/efst-a-baugi/frettir/ stok-frett/2019/02/07/Forsaetisradherra-undirritar-samning-vid-Samtokin-78 (accessed 19 April 2020).

Stjórnarráð Íslands (2019b) Forsaetisradherra undirritar samning vid Kvenrettindafelag Islands, June. Available at: https://www.stjornarradid.is/efst-abaugi/frettir/stok-frett/2020/02/18/Forsaetisradherra-undirritar-samning-vidKvenrettindafelag-Islands/ (accessed 19 April 2020).

Suchanow K (2020) How a harsh Polish abortion bill sparked women's strikes around the world. Open Democracy, 15 April. Available at: https://www.opendemocracy. net/en/5050/how-a-harsh-polish-abortion-bill-sparked-womens-strikes-aroundthe-world/ (accessed 17 April 2010).

Sunderland R (2009) After the crash, Iceland's women lead the rescue. Guardian, 21 February. Available at: https://www.theguardian.com/world/2009/feb/22/ iceland-women (accessed 18 April 2020).

Porvaldsdóttir P (2001) Af fegurðardísum, ástandskonum og fjallkonum. Lesið í táknmyndir hins kvenlega í íslensku menningarumhverfi. In: Agnarsdóttir A, Halldórsdóttir EH, Gísladóttir H, Hákonardóttir IH, Matthíasdóttir S and Porgrímsdóttir SK (eds) Kvennaslóðir. Rit til heiðurs Sigríði Th. Erlendsdóttur sagnfraðingi. Reykjavík: Kvennasögusafn Íslands, 493-506.

porvaldsdóttir PH (2011) The gender equal North: Icelandic images of femininity and masculinity. In: Ísleifsson SR and Chartier D (eds) Iceland and Images of the North. Québec/Reykjavík: Presses de l'Université du Québec, Collection Droit au Pôle/ReykjavíkurAkademían, 405-434.

Porvaldsdóttir PH (2014) Reimagining authoritative masculinity and the female slut: Snapshots from Reykjavík. In: Oddsdóttir EE, Sigurðsson AM and Svandal $\mathrm{S}$ (eds) Gender Equality in the Artic: Current Realities - Future Challenges. Reykjavík: Ministry for Foreign Affairs, 52-53. 


\section{Irma Erlingsdóttir}

Topping A and Redden M (2017) 'We are international, we are everywhere': Women united in global strike. Guardian, 7 March. Available at: https://www.theguardian. com/world/2017/mar/08/international-womens-day-political-global-strike (accessed 19 April 2020).

Tulinius K (2014) So what's this men's only UN Gender Conference I keep hearing about? Reykjavík Grapevine, 15 October. Available at: https:/grapevine.is/mag/ column-opinion/2014/10/15/so-whats-this-mens-only-un-gender-conference-ikeep-hearing-about/ (accessed 19 April 2020).

United Nations (2015) UN 'barbershop conference' aims to dispel stereotypes, promote gender equality. 15 January. Available at: https://news.un.org/en/ story/2015/01/488322 (accessed 19 April 2020).

Viktorin C, Gienow-Hecht JCE, Estner A and Will MK (2018) Beyond marketing and diplomacy: Exploring the historical origins of nation branding. In: Viktorin C, Gienow-Hecht JCE, Estner A and Will MK (eds) Nation Branding in Modern History. New York \& Oxford: Berghahn, 1-26.

Wittenberg-Cox A (2020) What do countries with the best coronavirus responses have in common? Women leaders. Forbes, 13 April. Available at: https://www. forbes.com/sites/avivahwittenbergcox/2020/04/13/what-do-countries-with-thebest-coronavirus-reponses-have-in-common-women-leaders/\#1e4c70103dec (accessed 19 April 2020).

Women Political Leaders (2014) Why Iceland is the world's global leader in gender equality? 24 March. Available at: https://www.womenpoliticalleaders.org/why-isiceland-the-world-s-global-leader-in-gender-equality/ (accessed 19 April 2020).

World Economic Forum (2020) Global Gender Gap Report 2020. Geneva: World Economic Forum. Available at: http://www3.weforum.org/docs/WEF_GGGR_2020. pdf (accessed 19 April 2020). 


\title{
6 Protecting the brand?

\author{
The hesitant incorporation of \\ gender equality in the peace nation
}

\author{
Inger Skjelsbak and Torunn L. Tryggestad
}

The international context in relation to gender and peacebuilding has changed dramatically over the last two decades, in ways that have had a major impact on the branding of Norway and other Nordic countries abroad. The most important change on the international scene was the adoption in October 2000 of UN Security Council Resolution 1325 on Women, Peace and Security. This resolution was inspired by, and adopted five years after, the Fourth World Conference on Women, convened by the UN in Beijing in 1995. The Beijing conference was the largest international women's conference that had ever been organized, and the first that had a strong focus on gender and armed conflict.

In broad terms, UN Security Council Resolution 1325 focuses on women's participation in peacebuilding; on their protection from gender-based violence and its prevention; and on women's inclusion in post-conflict relief and recovery activities (Tryggestad, 2009). Resolution 1325 also calls on the international community, including UN member-states such as Norway, to do more to include women in all matters related to international peace and security. In the years that have passed since the adoption of the resolution, nine follow-up resolutions have been adopted, and Norway has played an active global role, both normatively and financially, in advancing what has now formally become the Women, Peace and Security (WPS) agenda (Skjelsbæk and Tryggestad, 2019). Norway has become known as a WPS champion.

The WPS agenda has provided Norway with an opportunity to highlight and bring together two prominent features of its national self-identificationgender equality and peace promotion - at the global level. Norway was also one of the first UN member-states to adopt a national action plan on WPS in 2006 and has played an active role in promoting this agenda through various UN entities (such as the UN Peacebuilding Commission). More recently, the inclusion of women in peace mediation activities has become a central part of Norway's international peace and reconciliation efforts, most notably in Colombia (Salvesen and Nylander, 2017), which has also added to Norway's reputation as an ardent WPS supporter. Finally, WPS has been highlighted as a thematic priority for Norway's membership of the

DOI: $10.4324 / 9781003017134-6$ 
UN Security Council for the period 2021-2022 (Ministry of Foreign Affairs, Norway, 2020). Still, Norway appears to be reluctant to make the most out of the branding opportunity that this development represents. How can we understand this hesitance - and what impact does it have on the branding of Norway as a peace nation?

In this chapter, we discuss what the promotion of gender equality entails for Norwegian peace mediation efforts, along with the types of branding challenges and opportunities that emerge in this context. ${ }^{1}$ In addition, we ask how its involvement in such processes affects the gender-branding of Norway as a peace nation. We will examine these questions in the light of the establishment and practice of the Nordic Women Mediators (NWM) network and a set of Nordic national action plans (NAPs) that set out how the individual Nordic countries intend to follow up UN Security Council Resolution 1325 on Women, Peace and Security. A comparison with the other Nordic countries facilitates further understanding of why and how Norway has been so hesitant to incorporate gender equality in the branding of its role as an international peace mediator.

Proclaiming, like Sweden, that it will have a feminist foreign policy is not on the table in Norway. The term feminist cannot be found in any of the key documents adopted on Norwegian foreign policy, including the most recent action plans on WPS (Norwegian Ministries, 2019) and gender equality in foreign policy and development cooperation (Ministry of Foreign Affairs, Norway, 2016). A competitive space is thus emerging in which Norway is engaged in the highest number of peace and mediation efforts of all the Nordic countries (Wallensteen and Svensson, 2016), and Sweden is the most pronounced when it comes to gender engagement in its foreign policy, which serves to differentiate Norway and Sweden on the international scene. Sweden becomes the global forerunner on gender equality and women's rights, while Norway is less so even if the two countries have comparable histories on domestic and foreign engagement in this policy field. In Norway, there appears to be a tension within the foreign policy apparatus between, on the one hand, declaring Norway a global leader in terms of its commitment to gender equality in its foreign policy and, on the other, shying away from publicly and explicitly promoting the country's concrete efforts on gendernot to mention proclaiming Norwegian foreign policy feminist. As we argue below, these tensions stem from a particular conceptualization and practice of Norwegian peace mediation that emphasizes the virtues of being a neutral facilitator rather than a 'mediator with muscle'.

\section{Norwegian-style peacebuilding}

Engagement for peace has been an element of Norwegian foreign policy that has enjoyed considerable support among various governments, despite their differing political ideologies. 'Norwegian foreign policy remains stable,' has been a political mantra both in election campaigns and in the declarations 
of a range of different foreign ministers in recent decades. This engagement has been uncontroversial and viewed almost as an extension of seemingly inherent Norwegian national characteristics: a small state with benign intentions coupled with a non-colonial past. ${ }^{2}$ In a study of newspaper articles on Norway's peace engagement in the period 1993-2003, a dominant discourse can be detected in which 'Norway was invested with considerable agency, power and ability in promoting peace, with discursive links between "Norway", "peace promotion" and "success" being established' (Skånland, 2010: 35).

In parallel with the contemporary notion of Norway as a peace nation, Norwegian gender-equality policies emerged in the 1980s and 1990s within the country's domestic political arena after a period of strong Nordic state feminism and the rise of prominent female politicians (Hernes, 1987). These policies were particularly epitomized by the social democratic government led by Gro Harlem Brundtland (Norway's first woman prime minister), when Brundtland in 1986 formed the world's most gender-balanced government to date with a $40 \%$ representation of women ministers.

In tandem, these two dimensions of Norwegian public identity formation have created a sense of Norwegian exceptionalism - a way of thinking and arguing that promoting peace and gender equality is an essential ingredient of a Norwegian national identity and core societal values. Interestingly, and despite the prominence of pro-gender norms and policies in Norwegian society overall, the articulation of gender-equality norms and aims has until recently not been as explicit within Norwegian foreign policy, at least not in the 'traditional' domains of foreign policy nor in the field of peace and reconciliation engagements. We also observe that the integration of gender-equality norms within Norway's peace engagement has not been addressed in the existing body of literature that explores in considerable depth Norway's engagements for peace in the Middle East, Sri Lanka and Sudan (Taulbee et al., 2014; Nissen, 2015; Salter, 2015), despite the fact that central actors in these processes have argued that they were concerned with gender dimensions (Skjelsbæk and Tryggestad, 2020).

The role that Norway has come to take on within international peace mediation must be viewed against a long historical backdrop. Considerable emphasis has been placed on peace engagement within Norwegian foreign policy, and some have argued that it has been the most central aspect of Norwegian foreign policy since even before Norway gained its independence from Sweden in 1905 (Knutsen et al., 2016: 96). ${ }^{3}$ Post-independence, the Norwegian nation-building project was based in part on the notion of Norway and Norwegians as a particularly peace-loving nation and people (Leira, 2013). The fact that it is Norway that awards the annual Nobel Peace Prize, while Sweden awards the other Nobel prizes, has added to this self-perception.

There is a large Norwegian literature on the trajectories of the Norwegian peace engagement (e.g. Tamnes, 1997; Pharo, 2005; Knutsen et al., 2016) and 
its role in nation-branding (e.g. de Carvalho and Neumann, 2015). What this literature points to is that peace engagement has been a key pillar of Norwegian foreign policy since at least the 1960s. In the 1960s, Foreign Minister Knut Frydenlund (1966: 143) defined the following three goals of Norwegian foreign policy: securing Norway's freedom and sovereignty; securing Norway's interests; and, last but not least, contributing to securing global peace and promoting cooperation between peoples. The argument that it is in Norway's interest to actively engage in international peace and security efforts has been made by every foreign minister since Frydenlund's time. The same argument was also advanced as a key justification for why Norway was seeking a non-permanent seat at the UN Security Council for 2021-2022. For a long period, Norway's peace engagement first and foremost took the form of contributions to UN peacekeeping operations and political and financial support to the UN system and multilateralism. From the early 1990s onwards, however, Norway has become just as well known for its many bilateral peace engagements around the world (Taulbee et al., 2014; Nissen, 2015; Wallensteen and Svensson, 2016; Keskinen et al., 2016).

According to the Norwegian MFA, since 1993 Norway has officially made active contributions to peace processes in the following conflict countries and regions (in alphabetical order): Afghanistan, Colombia, Guatemala, the Middle East, Myanmar, Nepal, the Philippines, Somalia, Sri Lanka, Sudan/ South Sudan and Venezuela. It is also engaged in a number of unofficial processes that do not form part of this list (Government.no, 2019a). The first major peace processes in which Norway engaged - the Oslo Process (Israel/Palestine) and the Sri Lankan peace process - were characterized by the involvement of profiled and politically ambitious individuals and quite extensive media attention (Nissen, 2015). Leading politicians from the Ministry of Foreign Affairs themselves took on active roles as mediators and facilitators. The engagement of these leading politicians led to high visibility, but also raised the stakes in terms of political costs if their efforts proved unsuccessful. One example of this risky dynamic came in 2004 when anti-Norwegian rallies were organized in Sri Lanka's capital, Colombo, and a doll depicting the Norwegian Special Advisor Erik Solheim was set on fire. The majority of the profiled individuals involved in Norwegian peace mediation during the 1990s and early 2000s were men. Peace mediation had become an attractive career opportunity, bringing with it considerable status for the individuals involved. It also appeared as an activity that considerably strengthened Norway's small-state status in international politics (de Carvalho and Neumann, 2015).

In the early 2000s, however, the Norwegian peace engagement gradually changed its modus operandi. Norway remained active, but in a more lowkey manner. Top-level politicians at the MFA took on supportive roles and involved themselves more actively only when direct political support was required. More importantly, from the early 2000s Norway's peace engagement also became more professionalized. During the Norwegian engagement in 
the Sri Lankan peace process, a 'Sri Lanka Unit' was set up at the MFA in Oslo. In parallel with the Sri Lanka engagement, Norway was also involved in a number of other processes (e.g. in Sudan), and it became necessary to strengthen the ministry's support capacities for these types of activities. In 2001/2002, a decision was made by then State Secretary Vidar Helgesen to turn the Sri Lanka Unit into a Section for Peace and Reconciliation. The aim was to institutionalize and systematize the lessons and knowledge gained from previous and ongoing experiences to make peace mediation and reconciliation a profession within the MFA. The establishment of this section would also become a turning point for how issues related to the inclusion of women and gender perspectives were integrated into Norway's peace engagement.

What also came out of the professionalization process within the MFA was the operationalization of the 'Norwegian model for peace engagement', which was first conceptualized in the mid-1990s by then State Secretary Jan Egeland (Neumann, 2015). Some critics have argued that this is not really a model as such but rather a way of organizing Norway's peace engagement (Nissen, 2015). As of April 2019, Norway's peace engagement had the following general features (as outlined by the MFA):

- A long-term willingness to provide assistance, both for economic development and for peacebuilding.

- Provision of resources, both human and financial.

- Close cooperation with Norwegian NGOs, which have served as door-openers and providers of access.

- Experience, built over many years, including from working with nonstate actors.

- Good relations with key international actors, both individual states and multilateral organizations (particularly the UN).

- No colonial past; Norwegian engagement is perceived to be sincere and not motivated by political or economic self-interest. ${ }^{4}$

- A focus on peace facilitation rather than 'mediation with muscle'.

Interestingly, gender-equality norms or WPS are not mentioned on this list as core values or principles of the Norwegian peace engagement model, even though the inclusion of women and the integration of gender perspectives within peace processes had already become an integral part of Norway's most recent peace engagements when it was made (Tryggestad, 2014; Salvesen and Nylander, 2017; Norwegian Ministries, 2019). In December 2019, the presentation of the Norwegian peace engagement on the official webpage of the MFA was updated, but WPS is still not listed among the 'Hallmarks of Norway's Peace and Reconciliation Work'. Some brief statements on how Norway has facilitated the inclusion of women in peace processes have been included, along with a link to further information on Norway's activities in relation to WPS (Government.no, 2019b). However, 
there are no explicit statements on how or where Norway intends to take this agenda further.

The omission of WPS from the list of 'Hallmarks of Norway's Peace and Reconciliation Work' is also reflected in the actual practice of peace engagement. Often operating under time constraints, Norwegian diplomats (mainly men, but also women) involved in the country's peace engagement efforts admit that they have repeatedly experienced shortcomings in terms of the operationalization of priorities and the implementation of policies related to gender equality. ${ }^{6}$ While they may have had good intentions in relation to the appointment of women as lead peace facilitators, team leaders and thematic experts on the Norwegian side, they have often found it difficult to carry these intentions through in practice, the argument being that they usually mobilized teams and experts on short notice and did not have a sufficiently good overview of women within the foreign policy apparatus or Norwegian civil society with the specific competences required (generally a combination of thematic expertise and language skills). Until the mid- to late 2000s, like many other countries, Norway was therefore paying lip service to gender-equality ambitions in peace processes but not doing particularly well in practice in terms of including either women or gender-equality norms and perspectives in Norwegian peace engagements.

We will argue that this lack of focus on gender equality in peace engagement is related to the nature of Norwegian-style peacebuilding, as described in a study on peace diplomacy by Wallensteen and Svensson (2016), who have argued that there is a distinct difference between Norway and its Nordic neighbours in this context, in that Norway emphasizes its role as a $f a$ cilitator, while the other countries of the region place greater emphasis on the mediator role. The Norwegian approach, then, might be compared to a situation where one invites guests to a dinner party by opening their house for visitors and letting them decide the menu, rather than a dinner party where the menu is already set by the host. But how does the notion of gender equality complicate this role?

\section{Norwegian-style gender equality}

It is puzzling that gender equality is seen as such a central aspect of Norwegian identity but still not put centre-stage in the country's peace and reconciliation efforts. One explanation for this, however, can be found in the conceptualization of state feminism, a term that was first coined by Helga Hernes in 1987. The fundamental element of state feminism is the idea that the state can act as a constructive partner, even a guarantor, to promote greater social equality between men and women. Hernes (1987) argued that feminist goals could be promoted by women entering into a partnership with the state - by women taking on leading political roles and taking ownership of policy development. However, the development and implementation of woman-friendly and gender-equal social policies would be dependent on 
continuous pressure from below, from women and women's organizations. During the 1980s, according to Hernes (1987: 157), the Scandinavian social democracies appeared to have 'the potential to be woman-friendly'. At the time, however, such an approach went against the sceptical view of the state that prevailed in many feminist milieus (both scholarly and activist), where it was customary to analyse the state system as a manifestation of general male domination, as one of the core problems of patriarchal power. Hernes, on the other hand, argued on the basis of historical analysis and contemporary observations that, in time and given the correct socio-democratic conditions, the state could become an ally of the feminist cause (see Larsen, Chapter 1 of this volume).

Since that time, gender equality has permeated Norwegian society as a norm, but not always as a reality in all spheres of life (see Holst and Teigen's discussion in Chapter 8 of this volume). While Norwegian society has changed quite fundamentally since the 1980s, some scholars have noted that the state feminist model may have morphed into a foreign policy mode of operating (Tryggestad, 2014). As Skjeie (2013: 29) notes:

The older understanding survives... and is of course reflected particularly strongly in UN policy development and institution-building in the area of gender equality... [S]tate feminism today [is] perhaps more relevant transnationally than in a Norwegian or Nordic context.

Skjeie goes on to describe state feminism as a kind of achievable utopia, as though the state feminist society would be a woman-friendly society in which gender would not determine what one can do - almost as though it had been erased. In this 'achievable utopia', Norway's economic wealth is seen as linked to gender-equality politics, which, in turn, becomes a form of political currency on the international stage. Clearly, achievable utopias are also a goal in peace and reconciliation efforts - to enable societies to move away from a violent past towards an imagined peaceful and prosperous future. Gender equality, then, through a state feminist model with mobilization from below and a friendly state apparatus above, becomes not only an idealized future but an achievable one. This is both rhetoric and practice for Norwegian peace mediators.

One example of this was seen when the World Development Report 2011 was launched in Norway (World Bank, 2011). At the launch, then Minister of International Development and Environment Erik Solheim (who had previously been the Norwegian Ministry of Foreign Affairs' special advisor to Sri Lanka) gave opening remarks in which he underscored that gender equality was just as important for Norwegian economic growth as the discovery of oil off the Norwegian coast in the early 1970s (Journalen, 2011). This point has been reiterated by several Norwegian ministers, including former prime minister Jens Stoltenberg. In a speech on 8 March 2012, Stoltenberg stated that the economic value of the participation of Norwegian women in the 
workforce was higher than that of Norway's oil revenue (Aftenposten, 2012), and he warned that if the participation of women in the Norwegian workforce was reduced down to the OECD average, the value of the production loss would equal Norway's total oil wealth, including values not yet extracted.

Such statements serve two rhetorical purposes. First, they have a 'look to Norway" ${ }^{7}$ effect in which the country's experiences of economic growth are intimately linked to its national gender-equality, identity and welfare politics; second, they suggest that Norway has experiences that can be beneficial to other countries. The argument made by prominent politicians is that Norway can offer knowledge and expertise based on its own experience, and that countries can get wealthier if they prioritize gender equality. ${ }^{8}$ This combination - the positive domestic experience with gender-equality policies and a willingness to share this knowledge internationally - has become a foreign policy currency, especially in the domain of development cooperation.

The adoption of UN Security Council Resolution 1325 in 2000 provided an opportunity for Norway to make use of this currency in a new domain of its foreign policy - notably, in its peace engagement - though this was something that needed to be done with care. A core concern in this context turns on terminology and the difference between Sweden's outspoken emphasis on a feminist foreign policy and Norway's cautious emphasis on gender equality. In Norway, 'feminism' is regarded as a divisive, prescriptive term, representing a political project with a radical, transformative agenda. 'Gender equality', on the other hand, 'is typically understood in terms of a harmonious, linear process of gradual development' (Teigen and Wängnerud, 2009: 25) or as a harmonious collaboration with the state, as a practice. In the Norwegian context, 'gender equality' has emerged as a value-laden term around which there is considerable consensus. It has emerged as an identity marker of a core value that characterizes 'us'. 'Gender equality' has thus become a descriptive term for a national identity.

Below, how Norway balances its cautious approach to gender in its peace mediation efforts and engagement will be illustrated through an examination of two examples: the Nordic countries' national action plans (NAPs) on UN Security Council Resolution 1325 and the Nordic Women Mediators network. In our view, a Nordic comparison on these matters provides further understanding of why Norway is so hesitant to incorporate gender equality in its branding as a peace nation.

\section{Nordic competition over gender equality and peacebuilding}

Since the adoption of UN Security Council Resolution 1325 in 2000, a growing number of states have appeared on the international scene as 'womenfriendly', which often means that they have made gender-equality norms and images central to their foreign policy. Among the states gaining most 
attention for such policies are Australia, Canada, Sweden and the UK (Aggestam and Bergman-Rosamond, 2016; True, 2017; Aggestam et al., 2019). Sweden is taking the lead with a clearly stated feminist foreign policy. Aggestam and Bergman-Rosamond (2016: 325) have elegantly described what they term the 'three Rs' in Sweden's feminist foreign policy toolbox:

Representation, Rights, and Reallocation. In other words, Sweden seeks to promote women's representation and participation in politics in general and in peace processes in particular; to advocate women's rights as human rights, including women's protection from sexual and gender-based violence; and to work toward a more gender-sensitive and equitable distribution of global income and natural resources.

Clearly these are all priorities that Norwegian foreign policy-makers can subscribe to and have done for many years (Skjelsbæk and Tryggestad, 2019). Still, it is as though there is a resistance not only to the idea of relabelling these priorities under the f-word, but also to being explicit about Norway's efforts and achievements in relation to gender equality in its foreign policy. A critical reading of the various national action plans on UN Security Council Resolution 1325 produced by the Nordic states highlights this Norwegian resistance to feminist labelling, particularly in the comparison with Sweden.

The Nordic countries were among the first to develop NAPs on the implementation of Resolution 1325. Denmark was actually the first country in the world to do so in 2005 (Denmark, NAP 2005-2008), followed by Norway and Sweden in 2006, and Finland and Iceland had also developed their first NAPs by 2008. All the Nordic countries were therefore included among the first 12 countries to develop NAPs. And, as can be seen from Table 6.1, they have all developed subsequent NAPs that make the WPS agenda a central theme in their foreign policies, with increasing strength and emphasis.

In their various NAPs, all of the Nordic countries articulate different reasons for why the WPS agenda is important for them. Starting with very modest goals, Denmark does not articulate any particular national goals in relation to the WPS agenda in its first NAP (Denmark, NAP 2005-2008).

Table 6.1 Number of Nordic UN Security Council Resolution 1325 national action plans

\begin{tabular}{lllll}
\hline Country & First & Second & Third & Fourth \\
\hline Norway & $2006-2011$ & $2011-2013$ & $2015-2018$ & 2019-2022 \\
Sweden & $2006-2008$ & $2009-2012$ & $2016-2020$ & \\
Finland & $2008-2011$ & $2012-2016$ & $2018-2021$ & \\
Denmark & $2005-2008$ & $2008-2013$ & $2014-2019$ & \\
Iceland & $2008-2013$ & $2013-2016$ & $2018-2022$ & \\
\hline
\end{tabular}


Norway, however, sees the WPS agenda as integral to Norway's commitment 'to promote a more just world' (Norway, NAP 2006-2011: 2), ${ }^{9}$ while Sweden boldly addresses the lack of women in peacebuilding efforts and declares that 'Sweden is, and will continue to be, at the forefront of work to reverse this development' (Sweden, NAP 2006-2008: 1). Finland devotes a whole section of its first NAP to articulating why the WPS agenda is important for Finland and states that 'the promotion of the rights of women and girls is one of Finland's human rights policy priorities' (Finland, NAP 2008-2011: 11). Iceland declares in its first NAP that one of the objectives of its engagement on WPS issues 'is that Iceland's special status and strength in the area of gender equality will become more visible' (Iceland, NAP 2008-2013: 2).

All of the Nordic countries have revised and updated their NAPs over time and have produced at least three different plans, with Norway being the exception with four. They all address similar aspects of the WPS agenda, linked to peacebuilding, peacekeeping, gender-based violence, reporting and accountability, and funding. Over time, the NAPs become longer, are given a more professional appearance and use more glossy paper. With each new NAP, commitments, strength of language and mode of tracking implementation increase. The fact that the WPS agenda has become a policy area in which the Nordic countries seek to shine on the international stage also becomes apparent with each new NAP. The NAPs develop into a competitive space in which they seek to portray themselves as forerunners on the WPS agenda.

A good example of this development is provided by the case of Denmark, which did not articulate particular national goals linked to the WPS agenda in its first NAP, but devotes several pages to the centrality of the agenda for Denmark in its third NAP, in which it does not fail to mention that Denmark was the first country in the world to develop a NAP. Further, this third NAP states that 'the promotion of the women, peace and security agenda is a cornerstone in Denmark's foreign, security and development policy [because] we know that inclusive and equal societies are essential to prevent continued violence and foster sustainable peace' (Denmark, NAP 2014-2019: 7), which links foreign policy aims with domestic experiences with gender equality, as well as peace with its neighbours.

Sweden stands out because it sees itself as a model country, not only morally committed to taking the lead, as articulated in the first NAP, but also a 'look-to country' for others, as articulated in its second NAP, in which it is declared that 'Sweden was one of the first countries to adopt a national action plan and the Swedish plan has attracted interest and inspired several other countries and international organisations' (Sweden, NAP 2009-2012: 6). In its most recent NAP, Sweden's leadership is emphasized to an even greater extent, and the commitment to a Swedish feminist foreign policy is introduced when it is stated that 'Sweden's feminist foreign policy has a clear focus on supporting women as actors for peace and security' (Sweden, 
NAP 2016-2020: 3). A few sentences later, this particular form of foreign policy is directly linked to the WPS agenda when it is stated that 'Sweden will have clear political leadership to further the Women, Peace and Security agenda' (Sweden, NAP 2016-2020: 3).

Finland maintains its commitment to women's rights as human rights in its subsequent NAPs. It also points out that

since Finns have experienced wars and conflicts, they have an understanding of the long-term impact that conflicts can have both on individuals and entire nations, including the profound impact on the structures of society and the way in which it functions.

(Finland, NAP 2018-2021: 8)

Iceland presented a comprehensive new NAP in 2018 in which it traced national and international developments linked to WPS. However, perhaps most importantly in the context of nation-branding, this NAP enabled Iceland to position itself as a model country for others when it stated:

Iceland ranks as the most gender equal country in world according to the Global Gender Gap Report. Furthermore, Iceland is among the safest countries in the world. These two facts allow the Icelandic government to be both a strong and a credible representative of the message contained in Resolution 1325: that gender equality goes hand in hand with stability and peace in the international community.

(Iceland, NAP 2018-2022: 7)

While all the other Nordic countries have become increasingly bold in their statements about what the WPS agenda means for them, Norway maintains a different tone and language throughout its four NAPs. Though ministers and others have boasted about Norway as a gender-equal superpower in their speeches, we do not find the same language in the NAPs themselves. The slogan of the Norwegian campaign for a non-permanent seat in the UN Security Council for the period 2021-2022 was 'consistent partner, common future'. This slogan also sums up Norway's nation-branding in the NAPs. Norway's aim in its commitment to the WPS agenda is described in its first NAP as being 'part of our endeavour to promote global security, peace and justice' (Norway, NAP 2006-2011: 1). In relation to peace mediation in particular, the second NAP states that 'Norway will promote the participation of women and an integrated gender perspective in peace processes and negotiations' (Norway, NAP 2011-2013: 6), an approach that is very different from that of the Swedes, who aim to take the lead (see quote above). The language does not get any stronger in the following NAP, in which it is stated that 'Norway will play its part in implementing the Security Council resolutions through political leadership, targeted efforts across different sectors, diplomacy and financial support' (Norway, NAP 2015-2018: 5). Finally, 
what is offered in the most recent NAP is more systematization when it is stated that

Norway will have a more systematic focus on women, peace and security in our efforts to support the implementation of peace agreements, strengthen the gender perspective in international operations and missions, and increase our efforts for women and girls in our humanitarian work.

(Norway, NAP 2019-2022: 4)

It is as though Norway's track record in gender equality and peace engagements is simply assumed instead of being articulated. The branding efforts lie in consistency, hard work and good intentions, as illustrated in the following passage about how gender equality and peacebuilding are conceptualized by Norway:

Norway is working to ensure that peace and reconciliation processes are inclusive and that peace agreements safeguard women's and men's rights, needs and priorities. We strive to ensure that more women participate at all levels in peace and reconciliation efforts, and that everyone who is involved in a peace process knows how to integrate the gender perspective in their work.

(Norway, NAP 2019-2022: 12)

Why has Norway opted for such toned-down language in such important branding documents? Why, unlike its Nordic neighbours, does Norway not spell out the differences that make Norway unique in the domain of WPS? Before discussing this further, we will revisit the Nordic Women Mediators (NWM) network, which has become a site for national collaboration on and competition over how to brand something that all the Nordic countries seem to be good at - namely, gender equality and peace - but which they talk about and showcase in very different ways.

\section{The Nordic Women Mediators (NWM) network: competitive collaboration}

As a direct follow-up to the creation of a network of women mediators in the Southern African region in 2014, the Nordic Women Mediators (NWM) network was initiated by the Norwegian government and formally launched in Oslo in November $2015 .^{10}$ The central idea of the network was to assemble an easily accessible overview/list of Nordic women with direct experience of peace mediation/peace facilitation. ${ }^{11}$ Women included on this list should be individuals qualified for high-level international positions (such as peace envoys and heads of missions) as well as thematic experts who could join peace mediation teams. The aim was both to facilitate access to women who 
could be recruited to peace mediation positions and to establish a network in which they could share their experiences and learn from each other.

At the time of the network's launch, the Norwegian MFA's Section for Peace and Reconciliation was headed by Tone Allers, a woman who herself had direct experience from Norwegian peace facilitation efforts in both Colombia and the Philippines. She was strongly committed to the WPS agenda, as were many other employees in the Section (both women and men). Still, Norwegian diplomats took care to emphasize that the new network should not be promoted as a Norwegian but rather as a Nordic initiative, and it was seen as way of creating better peace processes, not as a network with articulated feminist or nationalist goals. The importance of involving the governments of all five Nordic countries was stressed. Two processes were initiated in parallel: while Norwegian diplomats reached out to their working-level counterparts in the other Nordic countries to assess the interest in a regional network, the Norwegian Centre for Conflict Resolution (NOREF) and the Peace Research Institute Oslo (PRIO) were commissioned to develop a concept note, make a first rough list of possible network members (from all of the Nordic countries) and start mapping potential operational partners in the Nordic countries. In this initial phase of the project, the Norwegian MFA's main objective was to develop a network primarily of women with direct experience from Track One processes. ${ }^{12}$ Accordingly, the group of women would be small and exclusive.

It soon became clear, however, that while Norway could provide the names of quite a few women with this kind of hands-on experience (relative to the overall number of women in international peace mediation), the other Nordic countries were unable to do the same. These countries had been involved in fewer peace processes, and few women had been involved in such activities. Norway could therefore have moved along on its own, developing a unique network of Norwegian women experts, but chose to stick to the original idea of developing a Nordic network and not portraying Norway as going at this alone. While there was interest in the initiative among all the other Nordic countries, they differed in their approaches to the project. Finland immediately expressed support along the lines of Norway's thinking. Iceland also expressed support and interest, but wanted to expand the notion of 'mediation' to include women with experience from different types of international negotiations (such as fishery negotiations). Denmark was initially lukewarm, with reference to lack of both financial resources and lack of direct experience from international conflict mediation. When it eventually decided to become involved, however, Denmark was the strongest proponent of the need to apply a broad understanding of "peace mediation', one that would also encompass conflict resolution and peacebuilding (areas in which Denmark had much more experience). Finally, Sweden also opted to support the Nordic network initiative, but clearly saw this as an opportunity to link the initiative with its feminist foreign policy, an approach that was quite at odds with Norway's aims. 
Here, again, we observe the differences in how the Nordic countries approach the question of nation-branding, and these are perhaps most notable in relation to Norway and Sweden. While Norway's approach from the very beginning was that of serving as a network facilitator - and emphasizing the network initiative as a collective Nordic effort - Sweden has more explicitly used the network as an opportunity for self-promotion abroad. Instead of making the most out of the NWM initiative as an opportunity to brand Norway as the leading 'gender-equal peace nation', Norway prioritized Nordic collaboration and sought to make Norway blend in with its neighbours.

Today, the NWM network consists of around 50 women professionals from the five Nordic countries with expertise in conflict mediation, peace negotiations and peacebuilding (broadly defined). Although the institutional expertise and affiliation of many of its members are listed as international and regional organizations, as well as civil society, the vast majority of the members are professionals working within - or recently retired from - the ministries of foreign affairs of the five Nordic countries. This adds a particularly interesting competitive layer to the collaboration. In addition to the Nordic-level network, each Nordic country has also established national networks of women mediators as branches of the overarching NWM. The size, organization and scope of the activities of these five national networks vary. The Norwegian network is by far the largest (counting close to 60 women), while the membership of the other four national networks ranges from 15 to 20 members. The size of the Norwegian network is a reflection of Norway's long-time peace engagement, which during the last ten years has gradually provided an increasing number of women, both within the MFA and in Norwegian civil society, with thematic and technical experience from peace facilitation and peace negotiations. It is also a reflection of Norway's emphasis on professionalizing peace mediation by including thematic expertise among the membership, rather than making the NWM more explicitly political and value-driven (as in the case of Sweden). Norway's 'peace mediation dominance' could have provided Norway with a unique branding opportunity. Still, Norway refrained from adopting such an approach. The members of the Norwegian network are members in their personal capacity and generally maintain a low profile in the public arena. The Swedish network, on the other hand, stands out and comprises a small number of carefully selected senior women who operate as personal envoys of the Swedish minister of foreign affairs (the network members were initially appointed directly by former minister of foreign affairs Margot Wallström), and has been branded as an important instrument of Swedish feminist foreign policy.

Further, while all the other Nordic countries have named their national networks NWM (Nordic Women Mediators) followed by the country name (e.g. NWM-Denmark, NWM-Finland) - and in so doing emphasize the regional connection - Sweden named its national network the Swedish Women's Mediation Network, with no direct reference to its being part of a larger regional or Nordic initiative. Although the Swedish government was already 
in dialogue with Norway and the other Nordic countries about the establishment of the NWM, and plans had been made for its formal launch in Oslo in November 2015, Sweden moved ahead and announced its Swedish Women's Mediation Network during the UN General Assembly in September 2015 (Folke Bernadotte Academy, 2015). As can be seen in the ways in which Sweden has articulated its role in the NAPs, as discussed above, it should come as no surprise that Sweden also in the context of this network wanted to take the lead and stand out. The Swedish feminist foreign policy commits it to doing so - this is something that they feel other nations expect from them, and on which the Swedish government delivers.

\section{Conclusion}

Since the launch of the NWM in 2015, there has been a mushrooming of regional women mediators' networks around the globe. ${ }^{13}$ A Global Alliance of all these regional women mediators' networks was launched during the high-level week of the UN General Assembly in September 2019. In all these different regional processes, the Nordic countries have been involved in various ways - either in consultative roles or through the provision of political and financial support - with Norway operating as a driving force. In the case of the establishment of the Global Alliance, Norway was also the initiator and key facilitator, hosting the first consultative meeting in Oslo in March 2018. However, Norway was once again reluctant or careful not to take on a role that was too prominent or visible or to use these various network initiatives for its own branding purposes. On the contrary, while it has been important for Norway to brand the NWM as a Nordic collaborative effort, in the case of the Global Alliance it seems to have been even more important to downplay any national interests and to focus instead on facilitating inter-regional collaboration on and commitment to a global cause. Here again, then, we see how Norway's approach to both peace engagement and the advancement of the WPS agenda is heavily influenced by its selfperception as a facilitator. We suggest that this is not based on any form of innate characteristics of Norwegians as modest or humble, but must be seen as being linked to Norway's broad engagement in peace and reconciliation efforts around the globe. Boasting about gender equality or coming across as someone who is imposing gender norms - even when this might serve the country well within the competitive space of the WPS agenda-could come at a cost for Norway's many peace engagements. Since Norway's peace engagement enjoys considerable bipartisan political support in Norway, is a source of popular pride (though there are also critical voices) and provides the country with access to heavyweight political players on the international stage, an overly outspoken focus on gender equality could be risky politics for Norway.

Still, the need to be seen as a state with strong gender-equality policies also in the domain of foreign policy is an important currency in the intricate 
game between states on the international scene (Wohlforth et al., 2017; Aggestam and Towns, 2018). The challenge for Norway here is to be recognized without gloating - and without proclaiming a feminist foreign policy.

Being among nations of 'firsts' on domestic gender-equality policies since the 1980s, it is also interesting that it was the African region that provided the direct impetus for the establishment of a Nordic Women's Mediators network. The Nordic network did not emerge as a Nordic political innovation, as so many other gender-equality initiatives have. In their thorough account of Nordic peace mediation, Wallensteen and Svensson (2016: 173) point out that the higher the positions women hold in a given society, the more likely it would seem that peace mediation activities will be characterized by gender dimensions and gender equity. It is therefore surprising that the Nordic countries historically have fared quite poorly in this domain.

On this, Norway is no exception. In its engagements from the Middle East, to Guatemala, the Balkans, Sri Lanka and Sudan, neither women's participation in peace processes nor the inclusion of gendered language in peace agreements has been high on the agenda. There were attempts to integrate gender dimensions into these processes, but they were on the side and marginal. For a long time, in other words, there has been a gap between the practice and the rhetoric of peace mediation. In more recent peace engagements, however, such as those in Colombia and the Philippines, a change can be observed. There seems to be a cautious and meticulous effort to focus on the inclusion of gender-equality norms as part of a pragmatic approach to mediation design while at the same time downplaying any suggestion that this should be seen as a feminist transformative value-based project. Gender-equality measures draw on the state feminist model of practice: mobilization from below with a friendly state apparatus above. The NAPs and the NWM network have been important sites for balancing the aims of promoting gender equality and peace engagement. Norway is consistently a low-key player. At a time when a growing number of like-minded states are adopting feminist foreign policies, it remains to be seen whether Norway's balancing act will continue to serve Norwegian interests, identity and image well. On this question, the jury is still out.

\section{Notes}

1 This chapter builds on Skjelsbæk and Tryggestad (2020). The edits and rewriting have been approved by Foreign Policy Analysis.

2 The non-colonial image remains in the public mind despite the colonizing nature of Norway's culture and language policies towards the indigenous Sami population in Northern Norway, which lasted until the 1980s.

3 Following the Napoleonic Wars (1800-1815), Denmark lost the Norwegian territory to Sweden, leaving Norway in a union with Sweden from 1814 to 1905.

4 For a critical postcolonial perspective on the notion of the Nordic countries as outsiders to colonial power relations, see Keskinen et al. (2016).

5 This information was found on the webpage of the Norwegian government and attributed to the Ministry of Foreign Affairs; see Government.no (2019b). 
6 This has been shared with the authors both in formal interviews and in informal conversations.

7 This is an expression that stems from a speech by US President Franklin D. Roosevelt during the handover ceremony for the Royal Norwegian Navy ship HNoMS King Haakon VII at the Washington Navy Yard on 16 September 1942. The quote was as follows:

If there is anyone who still wonders why this war is being fought, let him look to Norway. If there is anyone who has any delusions that this war could have been averted, let him look to Norway; and if there is anyone who doubts the democratic will to win, again I say, let him look to Norway.

see Wikipedia (n.d.)

8 For many years, this form of rhetoric was much used by politicians from the centre-left of Norwegian politics. In recent years, however, both national statistics and studies have supported this claim (see, for instance, Østbakken, 2016). Increasingly, Norwegian politicians and policy-makers make references to studies published by institutions such as the World Economic Forum (2017) and the World Bank (2018).

9 For ease of consultation, publication details for the national action plans of the individual Nordic countries have been grouped together in a separate section following the reference list.

10 See Hattrem (2015).

11 For more information, see the Nordic Women Mediators website at https:// nordicwomenmediators.org/.

12 'Track One' refers to official diplomacy that is carried out by official representatives of states or international organizations.

13 Other formally established regional networks are FemWise-Africa (2017), the Mediterranean Women Mediators Network (2017) and the Women Mediators Across the Commonwealth (2017). In addition, the ASEAN Women for Peace Registry (AWPR) was launched in December 2018, while a meeting was organized in Cairo in July 2019 to discuss the establishment of an Arab Women Mediators Network.

\section{References}

Aftenposten (2012) Kvinnejobber mer verdt mer enn oljen. 8 March. Available at: https://www.aftenposten.no/norge/i/3JOEv/kvinnejobber-mer-verdt-mer-ennoljen (accessed 15 April 2019).

Aggestam K and Bergman-Rosamond A (2016) Swedish feminist foreign policy in the making: Ethics, politics, and gender. Ethics \& International Affairs 30(3): $323-334$.

Aggestam K, Bergman-Rosamond A and Kronsell A (2019) Theorising feminist foreign policy. International Relations 33(1): 23-39.

Aggestam K and Towns A (2018) Gendering Diplomacy and International Negotiations. London: Palgrave Macmillan.

de Carvalho B and Neumann IB (eds) (2015) Small State Status Seeking: Norway's Quest for International Standing. London \& New York: Routledge.

Folke Bernadotte Academy (2015) FBA forms network of women peace mediators. Press release, 28 September. Available at: https://fba.se/en/newspress/ nyhetsarkiv/2015/fba-forms-network-of-women-peace-mediators/ (accessed 18 July 2020). 
Frydenlund K (1966) Norsk utenrikspolitikk i etterkrigstidens internasjonale samarbeid. Bind 2. Oslo: Norsk utenrikspolitisk institutt (NUPI).

Government.no (2019a) Norway's engagement in peace processes since 1993. Last updated 2 December 2019. Available at: https://www.regjeringen.no/en/topics/ foreign-affairs/peace-and-reconciliation-efforts/innsiktsmappe/peace_efforts/ id732943/ (accessed 15 April 2019).

Government.no (2019b) Hallmarks of Norway's peace and reconciliation work. Last updated 2 December 2019). Available at: https://www.regjeringen.no/en/topics/ foreign-affairs/peace-and-reconciliation-efforts/innsiktsmappe/norway-peacework/id446704/ (accessed 15 April 2019 and 23 June 2020).

Hattrem T (2015) Speech at the establishment of a Nordic Women Mediators Network. Nobel Peace Centre, Oslo, 27 November. Available at: https://www. regjeringen.no/en/aktuelt/women-mediators-network/id2464724/ (accessed 11 November 2020).

Hernes HM (1987) Welfare State and Woman Power: Essays in State Feminism. London: Norwegian University Press.

Holst C and Teigen M (2021) Silenced at the border: Norwegian gender-equality policies in national branding. In: Larsen E, Moss SM and Skjelsbæk I (eds) Gender Equality and Nation-Branding in the Nordic Region. Abingdon: Routledge, 000-000.

Journalen (2011) Likestilling skaper økonomisk vekst. 28 November. Available at: http://journalen.hioa.no/innenriks/2011/11/likestilling-skaper-okonomisk-vekst (accessed 15 April 2019).

Keskinen S, Tuori S, Irni S and Mulinari D (2016) Complying with Colonialism: Gender, Race and Ethnicity in the Nordic Region. London: Routledge.

Knutsen TL, Leira H and Neumann IB (2016) Norsk utenrikspolitisk idéhistorie: 1890-1940. Oslo: Universitetsforlaget.

Larsen E (2021) 'The gender-progressive Nordics': A matter of history. In: Larsen E, Moss SM and Skjelsbæk I (eds) Gender Equality and Nation-Branding in the Nordic Region. Abingdon: Routledge, 13-38.

Leira H (2013). 'Our entire people are natural born friends of peace': The Norwegian foreign policy of peace. Swiss Political Science Review 19(3): 338-356.

Ministry of Foreign Affairs, Norway (2016) Frihet, makt og muligheter. Handlingsplan for kvinners rettigheter og likestilling i utenriks- og utviklingspolitikken 20162020. Oslo: Ministry of Foreign Affairs.

Ministry of Foreign Affairs, Norway (2020) The Security Council: Norway's priorities. 3 June. Available at: https://www.regjeringen.no/en/topics/foreign-affairs/ the-un/unsc_priorities/id2701066/ (accessed 16 June 2020).

Neumann IB (2015) Institutionalising peace and reconciliation diplomacy: Thirdparty reconciliation as system maintenance. In: Sending OJ, Pouliot V and Neumann IB (eds) Diplomacy and the Making of World Politics. Cambridge: Cambridge University Press, 140-167.

Nissen A (2015) The Peace Architects: Norwegian Peace Diplomacy Since 1989. PhD dissertation, Department of Archaeology, Conservation and History, Faculty of Humanities, University of Oslo.

Norwegian Ministries (2019) Women, Peace and Security (2019-2022): The Norwegian Government's Action Plan. Oslo: Norwegian Government Security and Service Organisation. Available at: https://www.regjeringen.no/globalassets/departementene/ ud/dokumenter/planer/actionplan_wps2019.pdf (accessed 19 July 2020). 
Østbakken KM (2016) Likestilling og verdiskaping. Om kvinners yrkesdeltakelse og dens betydning for økonomisk vekst. Report 2016: 10. Oslo: Institute for Social Research.

Pharo H (2005) Den norske fredstradisjonen - et forskningsprosjekt. Historisk tidsskrift 84(2): 239-255.

Salter M (2015) To End a Civil War: Norway's Peace Engagement in Sri Lanka. London: C. Hurst \& Co.

Salvesen H and Nylander D (2017) Towards an Inclusive Peace: Women and the Gender Approach in the Colombian Peace Process. Oslo: Norwegian Centre for Conflict Resolution (NOREF).

Skånland ØH (2010) 'Norway is a peace nation’: A discourse analytic reading of the Norwegian peace engagement. Cooperation and Conflict 45(1): 34-54.

Skjeie H (2013) Hva var statsfeminisme? In: Thun C and Bråten B (eds) Krysningspunkter. Likestillingspolitikk $i$ et flerkulturelt Norge. Oslo: Akademika, 29-43.

Skjelsbæk I and Tryggestad T (2019) Donor states delivering on Women, Peace and Security: The case of Norway. In: Davies SE and True J (eds) Oxford Handbook on Women, Peace and Security. Oxford: Oxford University Press, 516-528.

Skjelsbæk I and Tryggestad TL (2020) Pro-gender norms in Norwegian peace engagement: Balancing experiences, values, and interests. Foreign Policy Analysis 16(2): 181-198. doi:10.1093/fpa/orz028.

Tamnes R (1997) Norsk utenrikspolitikks historie, Bind 6. Oljealder 1965-1995. Oslo: Universitetsforlaget.

Taulbee JL, Kelleher A and Grosvenor PC (2014) Norway's Peace Policy: Soft Power in a Turbulent World. New York: Palgrave Macmillan.

Teigen M and Wängnerud L (2009) Tracing gender equality cultures: Elite perceptions of gender equality in Norway and Sweden. Politics \& Gender 5(1): 21-44.

True J (2017) Gender and foreign policy. In: Beeson M and Hameiri S (eds) Navigating the New International Disorder: Australia in World Affairs 2011-2015. South Melbourne: Oxford University Press, 224-241.

Tryggestad TL (2009) Trick or treat? The UN and implementation of Security Council Resolution 1325 on Women, Peace, and Security. Global Governance: A Review of Multilateralism and International Organizations 15(4): 539-557.

Tryggestad TL (2014) State feminism going global: Norway on the United Nations Peacebuilding Commission. Cooperation and Conflict 49(4): 464-482.

Wallensteen P and Svensson I (2016) Fredens diplomater. Nordisk medling från Bernadotte till Ahtisaari. Stockholm: Santérus Förlag.

Wikipedia (n.d.) Look to Norway. Available at: https://en.wikipedia.org/wiki/Look_ to_Norway (accessed 17 August 2018).

Wohlforth W, De Carvalho B, Leira H and Neumann IB (2017) Moral authority and status in international relations: Good states and the social dimension of status seeking. Review of International Studies 44(3): 526-546.

World Bank (2018) Unrealized Potential: The High Cost of Gender Inequality in Earnings. Washington, DC: World Bank.

World Bank (2011) World Development Report 2011: Conflict, Security and Development. Washington, DC: World Bank.

World Economic Forum (2017) Global Gender Gap Report 2017. Geneva: World Economic Forum. Available at: http://www3.weforum.org/docs/WEF_GGGR_2017. pdf (accessed 19 July 2020). 


\section{National action plans}

Denmark, NAP 2005-2008, Denmark's Action Plan on Implementation of Security Council Resolution 1325 on Women and Peace and Security. Copenhagen: Ministry of Foreign Affairs and Ministry of Defence. Available at: https:// www.peacewomen.org/sites/default/files/Denmark $\% 202005 \% 20$ (English).pdf (accessed 19 July 2020).

Denmark, NAP 2014-2019, Denmark's National Action Plan for Implementation of UN Security Council Resolution 1325 on Women, Peace and Security 2014-2019. Copenhagen: Ministry of Foreign Affairs, Ministry of Defence and Ministry of Justice. Available at: https://www.peacewomen.org/sites/default/files/Denmark $\% 20$ National $\% 20$ Action \%20Plan\%202014-2019.pdf (accessed 19 July 2020).

Finland, NAP 2008-2011, UN Security Council Resolution 1325 (2000) - 'Women, Peace and Security': Finland's National Action Plan 2008-2011. Helsinki: Ministry of Foreign Affairs. Available at: https://www.peacewomen.org/sites/default/ files/Finlando\%202008\%20(English).pdf (accessed 19 July 2020).

Finland, NAP 2018-2021, Women, Peace and Security: Finland's National Action Plan 2018-2021. Helsinki: Ministry of Foreign Affairs. Available at: https://www. peacewomen.org/sites/default/files/03_18_Women_Peace_Security\%20(1)\%20(2). pdf (accessed 19 July 2020).

Iceland, NAP 2008-2013, Women, Peace and Security: Iceland's Plan of Action for the Implementation of United Nations Security Council Resolution 1325 (2000). Reykjavík: Ministry for Foreign Affairs. Available at: https://www.peacewomen. org/sites/default/files/iceland_nationalactionplan_march2008.pdf (accessed 19 July 2020).

Iceland, NAP 2018-2022, Iceland's National Action Plan on Women, Peace and Security 2018-2022. Reykjavík: Ministry for Foreign Affairs. Available at: https:// www.peacewomen.org/sites/default/files/Icelands-National-Action-Plan-onWomen-Peace-and-Security-2018v2(1).pdf (accessed 19 July 2020).

Norway, NAP 2006-2011, The Norwegian Government's Action Plan for the Implementation of UN Security Council Resolution 1325 (2000) on Women, Peace and Security. Oslo: Ministry of Foreign Affairs. Available at: https://www.peacewomen. org/sites/default/files/norway-nationalactionplan_march2006.pdf (accessed 19 July 2020).

Norway, NAP 2011-2013, Women, Peace and Security: Norway's Strategic Plan 20112013. Oslo: Ministry of Foreign Affairs. Available at: https://www.peacewomen. org/sites/default/files/nor_updatednap_2011-13.pdf (accessed 19 July 2020).

Norway, NAP 2015-2018, National Action Plan: Women, Peace and Security 201518. Oslo: Norwegian Ministries. Available at: https://www.peacewomen.org/sites/ default/files/Norway\%20Revised\%20NAP\%20(2015-2018).pdf (accessed 19 July 2020).

Norway, NAP 2019-2022, The Norwegian Government's Action Plan: Women, Peace and Security (2019-2022). Oslo: Norwegian Ministries. Available at: https://www. peacewomen.org/sites/default/files/actionplan_wps2019.pdf (accessed 19 July 2020).

Sweden, NAP 2006-2008, The Swedish Government's Action Plan to Implement Security Council Resolution 1325 (2000) on Women, Peace and Security. Available at: https://www.peacewomen.org/sites/default/files/swedish_nationalactionplan_ october2006.pdf (accessed 19 July 2020). 
Sweden, NAP 2009-2012, The Swedish Government's Action Plan for 2009-2012 to Implement Security Council Resolution 1325 (2000) on Women, Peace and Security. Available at: https://www.peacewomen.org/sites/default/files/sweden_ nap2012.pdf (accessed 19 July 2020).

Sweden, NAP 2016-2020, Women, Peace \& Security: Sweden's National Action Plan for the Implementation of the UN Security Council Resolutions on Women, Peace and Security 2016-2020. Stockholm: Government Offices of Sweden. Available at: https://www.peacewomen.org/sites/default/files/Sweden\%20NAP\%2020162020.pdf (accessed 19 July 2020). 


\title{
$7 \quad$ A useful tool? \\ Images of the Nordics in Swiss quota debates
}

\author{
Stéphanie Ginalski
}

If the Nordic countries are imagined to be gender superpowers, Switzerland is perceived as a much more conservative country as far as women's rights are concerned. For instance, women got the right to vote and to be elected at the federal level only in 1971, 123 years after men and more than 50 years after the Nordic countries enfranchised women. As a consequence, women were largely excluded from all decision-making positions in the public sphere during a large part of the twentieth century. The situation improved after the 1970s in the political sphere, but women remained largely out of power positions in the business sphere. This led to increasing debate during the last 15 years within Swiss society, notably concerning the potential introduction of quotas to increase the number of women within the boardrooms of the larger corporations. In these debates, the Nordic examples were repeatedly used. But, why were they used, and to what effect?

The aim of this chapter is to analyse the debates that took place in Switzerland concerning female quotas for corporate boards, and to see what images and representations of the Nordic countries were invoked by both supporters and opponents of the quota system. Indeed, as Ann Towns (2009, 2010) has shown, the status of women in society is now used as an international standard among states, making it possible both to differentiate between them and to evaluate and rank them in a hierarchical manner. More specifically, the focus is on the issue of gender parity in corporate boardrooms, which has typically become since the beginning of the twenty-first century a benchmark used to distinguish between countries that are considered 'good' or 'bad' in terms of their performance.

Generally speaking, the Nordic countries performed ahead of the pack in terms of gender equality within corporate boards. Norway, which is considered 'the snowball that started the international avalanche in getting women on boards' (Goldeng and Huse, 2017), is often held up by advocates of a quota system as a model to be followed. Indeed, Norway was the first country to introduce legislated quotas for corporate boards, a fact that has been used by the Norwegian government to attract foreign attention and interest in Norway (Danielsen and Larsen, 2015). Still, the effect of individual Nordic countries' efforts to promote their gender-equality policies abroad

DOI: $10.4324 / 9781003017134-7$ 
is not evident, because the uptake of Nordic gender-equality models abroad is always beyond the control of the Nordics themselves. Investigating how Nordic countries were used during the debate on gender quotas in the Swiss case therefore appears particularly interesting, notably with regard to Switzerland's conservative political culture, but also because the Nordic countries have pursued different policies on this matter. As we will see, highly different evaluations and interpretations of the Nordic gender-equality policies were given during the Swiss debates, following the political spectrum from right to the left. The issue of sanctions in particular gave rise to lively debate.

In the following, I conduct a systematic analysis of the discussions concerning the presence of women within corporations that took place in the Swiss parliament since the start of the debate in 2003. In addition, I investigate all relevant documentation on female quotas in Swiss firms produced by the Federal Commission for Women's Issues, which is the extra-parliamentary permanent commission established to examine all issues that affect the situation of women in Switzerland and equality between the sexes. The analysis also includes the main public declarations by the Swiss Employers Confederation on this issue, both because of its weight in the business sphere as an umbrella organization and because it has been a major opponent to the introduction of quotas. All of the sources used in this chapter are accessible on the websites of the Swiss parliament and the Swiss Employers Confederation.

The analysis covers the 15 years during which the debates on women's quotas took place. In June 2018, Switzerland's National Council - the lower house of the Parliament, representing the people - finally, by an extremely narrow margin, ratified the draft revision of the law on public limited companies proposed by the Federal Council, which aimed to increase the presence of women on the boards of directors of such companies to a level of $30 \%$, and on their executive boards to $20 \%$. The Council of States - the upper house of the Federal Assembly, representing the cantons - also approved the revision the following year, which meant that the proposition of the Federal Council was accepted, despite strong opposition from the parliamentary right and business circles.

\section{The rise of gender quotas in business}

The progressive political empowerment of women during the twentieth century represented a major paradigm shift. Indeed, women had been excluded from the rise of democracy in Western societies during the nineteenth century, as they were notably explicitly prohibited from voting (Fraisse and Perrot, 2002; Towns, 2009, 2010). The presence of women in economic decision-making positions, however, remained a neglected issue until the mid-2000s (Lépinard and Rubio-Marín, 2018: 3-6). At that time, the persistent gender inequality on corporate boards, at both the strategic and the 
executive levels, finally began to receive increasing attention from academic researchers (see, for example, Singh and Vinnicombe, 2004; Vinnicombe et al., 2008; Adams and Ferreira, 2009; Post and Byron, 2015), nongovernmental organizations ${ }^{1}$ and the media. In this context, the presence of women on corporate boards became one of the benchmarks that made it possible to rank the performance of states in relation to equality. For example, Egon Zehnder, a privately owned consulting firm advising senior executives and boards around the world, began to track and analyse gender diversity in the boardroom from 2004. Its published reports distinguish between 'Champions', 'Slow Movers' and 'Underachievers' (Egon Zehnder, 2018: 7). According to its latest report (Egon Zehnder, 2018: 11), the Nordic countries of Finland, Norway and Sweden are performing ahead of the pack, along with several others (Australia, Belgium, France and Italy), with an average of over $30 \%$ of the directors on their largest corporate boards being female.

Since the start of the twenty-first century, the increasing debate on the question of gender parity for corporate boards has led to a related debate on whether gender quotas should be used to promote equality. Although several countries, such as Norway, France, Denmark, Finland, and Germany, have gradually opted for such an approach, it remains highly controversial, and many countries have shown considerable reluctance to adopt such measures. In debates on the subject, Norway is often promoted as a forerunner in relation to both gender equality within corporations and the use of gender quotas. Norway's Gender Equality Act entered into force in 1979. Gender quotas were adopted on a voluntary basis by a majority of the political parties as early as the 1970s and were formally imposed by the state in 1981 for public commissions to begin with (Teigen, 2018). The debate that emerged later, from the mid-1990s onwards, regarding gender parity on corporate boards 'hit Norway particularly hard, as it interfered with a national self-image of being particularly successful in affairs of gender equality' (Teigen, 2018: 353). In the business sphere, women actually remained largely excluded from the boards of large corporations, accounting for barely $5 \%$ of the members between 1990 and 2002 (Huse, 2012: 14). In 2003, in order to address this situation, the Norwegian parliament passed legislation mandating gender quotas for corporate boards, according to which both men and women should hold at least $40 \%$ of board positions in all firms. The legislation was initially formulated as a threat to encourage business leaders to voluntarily increase the presence of women. If companies did not meet this target by July 2005, the legislation would be effected. The proportion of women did indeed improve, but failed to meet the $40 \%$ target. As a result, the government enacted the legislation, which included tough sanctions in the event of non-compliance that could go as far as the dissolution of the firm (Teigen, 2018: 347-348; see also Hoel, 2008). This led to a dramatic increase in the presence of women on the boards of Norwegian firms - from 6\% in 2002 to $40 \%$ in 2008 (Huse, 2012: 14). The adoption of quotas for corporate boards simultaneously represented both a continuation of the 
institutionalization of Norwegian gender-equality policy and a break from the state's previous policy of not intervening in the economy (Teigen, 2018).

After Norway, the implementation of female quotas for corporate boards occurred for most countries in the aftermath of the 2007-2008 financial crisis (Teigen, 2018: 341). Indeed, that crisis was largely perceived as the consequence of a toxic 'business masculinity', as Erlingsdóttir describes in Chapter 5 of this volume. An infamous claim was that the crisis would not have occurred 'if Lehman Brothers had been Lehmann Sisters' (Prügl, 2012; Roberts, 2012). As a result, the debate around female board quotas intensified within the European Union from 2008, and in 2012 the European Commission's Vice-President Viviane Reding announced the possibility of imposing gender quotas on the corporate boards of the largest listed companies in the European Union to include at least $40 \%$ of the under-represented gender by 2020 (Singh et al., 2015: 552; Lépinard and Rubio-Marín, 2018). European norms and incentives that favoured gender equality influenced national debates concerning the adoption of female quotas for corporate boards, among both supporters and opponents alike, with the latter calling for national prerogatives (Lépinard and Rubio-Marín, 2018). Moreover, there was a clear process of policy transfer and transnational diffusion, and the adoption of quotas in Norway had an effect on the EU's member-states (Lépinard and Rubio-Marín, 2018: 32). In France, for instance, Norway's example was 'praised' during the discussion preceding the introduction in 2011 of the Copé-Zimmerman Law, a quota legislation that aimed to increase women's representation on supervisory boards to at least $20 \%$ by 2014, and to 40\% by 2017 (Singh et al., 2015: 552-553).

Although the Nordic countries are globally perceived as being equally gender-progressive, they differ on the issue of female quotas in business (Agustín et al., 2018). Freidenvall (2018) has discussed how Sweden, unlike Norway, never enacted mandatory gender quotas. The resistance in Sweden to such a move was very strong because such measures were regarded as discriminatory and contrary to the principle of meritocracy. Political parties in Sweden therefore opted for voluntary party quotas in elected bodies, which have proven quite effective, and business actors implemented voluntary codes of conduct. In 1999, a regulation that sought to bring about increased gender balance on the boards of Swedish state-owned companies was adopted. Despite the absence of sanctions in the event of noncompliance, the objective of reaching a level of $40 \%$ for women by 2003 was achieved (Freidenvall, 2018: 383). In order to avoid legislated quotas, business elites established corporate governance codes, which were adopted as part of the Swedish Code of Corporate Governance in 2005. These applied to all large companies listed on the Stockholm stock exchange and included a stipulation of gender-balanced boards - though again excluding sanctions in the event of non-compliance. In 2014, the self-proclaimed 'first feminist government in the world' launched a bill on mandatory quotas for corporate boards that aimed at a level of representation of at least $40 \%$ for each 
gender on the boards of public limited companies and publicly owned firms, which was never enacted owing to strong opposition within the parliament (Freidenvall, 2018: 390). Legislated quotas have continually been perceived as undesirable interference by the state in the business sector.

In Denmark, gender quotas have also been very controversial and, unlike in Norway and Sweden, there are no gender quotas for political parties (Agustín et al., 2018). Despite this lack of incentive, Denmark's political elites have been characterized by a high representation of women since 1998 in comparison to other European countries (Agustín et al., 2018: 402). In relation to the private sector, where women's representation was less advanced, the use of quotas to improve the presence of women on corporate boards has faced strong opposition from the Liberal Party and private corporations. Different strategies have thus been adopted instead, including voluntary quotas and the adoption in 2012 of a law compelling the largest public and private firms to set goals for gender equality on their boards, an approach that has been labelled the 'Danish model' (Agustín et al., 2018: 414).

\section{Lagging behind the Nordic countries}

According to the above-mentioned report by Egon Zehnder (2018: 11), Switzerland was clearly lagging behind most European countries - and especially the Nordic countries - in relation to female membership on corporate boards. In 2018, only $22.3 \%$ of the members of the boards of the country's largest public companies were women. In comparison, France was in the lead with $42.1 \%$, followed by Norway and Sweden with $36.7 \%$ each. With $33.3 \%$ of board seats held by women, Finland was also above the Western European average of $29.0 \%$, while Denmark was the only Nordic country below that average, with $25.8 \%$.

Switzerland's backwardness can be explained by several factors. First, Switzerland remains a very conservative country when it comes to women's rights and can be considered something of an anti-model in comparison with the Nordic countries. For instance, all the Nordic countries introduced full political rights for women around the time of World War I, whereas Switzerland first did so in 1971 (Sineau, 2002: 634; Studer, 1996). In 1981, the principle of equality between women and men was enshrined in the Federal Constitution. However, the 1912 marriage law, which allowed a husband to forbid his wife to work outside the home if her doing so was considered a threat to their marriage, remained unchanged until 1987 (Schulz, 1994: 132). In addition, Swiss legislation was particularly underdeveloped in relation to childcare. For instance, maternity leave was only introduced in 2005, after a ten-year debate, and paternity leave is only about to be adopted in 2021. These examples illustrate the strong persistence of the male-breadwinner model in Switzerland, in contrast to, for example, the Swedish dual-income earner model (Freidenvall, 2018). 
Switzerland's conservatism was favoured by a political context marked by the dominant position of the country's major right-wing parties since the second half of the nineteenth century. The 'bourgeois bloc', a term that refers to the alliance between the country's right-wing parties and its most powerful business interest associations, has remained particularly stable across time, although its cohesion has been challenged since the beginning of the twenty-first century (see Mach et al., 2021).

Towards the end of the 1990s, two initiatives calling for the introduction of female quotas to ensure adequate or equal representation of women at the political level were overturned by rulings of the Federal Supreme Court (Kägi-Diener, 2014: 27). The presence of women among political elites has however increased steadily since they obtained the right to vote and to be elected at the federal level in 1971. In relation to corporate boards, several factors have contributed to slowing down a similar increase (see Ginalski, 2020). State-owned companies, which have often been the first to introduce female quotas (see, for example, Heemskerk and Fennema, 2014, on the Dutch case), are few in number. The importance of a military career for accessing board appointments has been an indirect obstacle for women, as the army is compulsory for men only. Another factor is the absence of the right of employees to be represented on company boards, which typically played a key role in the adoption of corporate board quotas in Norway when a parallel was drawn between employee representation and gender representation (Teigen, 2018). As a consequence, women comprised only 7.7\% of the members of the boards of directors of the 110 largest Swiss firms in 2000, and only $9.7 \%$ ten years later (Ginalski, 2020).

The backwardness of Switzerland in comparison with other Western countries led to growing debates within Swiss society from the beginning of the twenty-first century, which have crystallized around the issue of quotas. In November 2013, the Federal Council, which is the highest executive authority in the country, announced that women should make up 30\% of the board members of corporations owned by the state or with close ties to the Confederation by 2020. Two years later, it proposed a project to reform the country's company law. One of the key elements of this proposal was the introduction of gender quotas for public limited companies according to which women should constitute at least $30 \%$ of the members of their boards of directors and $20 \%$ of their executive boards by 2020 . Although the project was formulated as a mere recommendation and no sanctions were planned, it provoked significant opposition from the right-wing majority in the parliament as well as within the private sector.

The next sections will analyse the most salient aspects of the debate on gender equity within corporate boards since the first discussions in the Swiss parliament in 2003. The analysis will include the questions, postulates, interpellations and motions addressed by parliamentarians to the Federal Council, the parliamentarian initiatives proposed, and the different answers and declarations made by the Federal Council. ${ }^{2}$ 
More specifically, the analysis focuses on the different interventions that mentioned, in one way or another, the Nordic countries. Three main phases can be distinguished in the discussion concerning the introduction of female quotas in Swiss firms. The first began in 2003 and lasted until the financial crisis of 2007-2008, when the initial discussions on gender equity within corporate boards took place in the Swiss parliament. Women belonging to the Swiss Socialist Party and the Green Party carried out different actions in favour of quotas, which did not lead to the introduction of concrete measures. They frequently invoked Norway as a model and a forerunner in order to plead their case. The second phase began with the financial crisis in 2007, which contributed to the creation of a less radical image of the Norwegian model. The last phase started with the 2013 decision of the Swiss Federal Council to increase the presence of women on the boards of directors of large firms with close ties to the Confederation, and subsequently on the boards of public limited companies.

\section{'Progressive Norway': debating female business quotas in the Swiss parliament}

The debate started with a parliamentary initiative entitled 'Mehr Frauen in die Leitungen von Aktiengesellschaften', meaning 'More Women in the Management of Public Limited Companies'. This was launched on March 2003 by Franziska Teuscher, a member of the National Council, representing the Green Party. Teuscher's aim was to increase the percentage of women in the boardrooms of public limited companies listed on the stock exchange to at least $40 \%$. Moreover, she suggested that these companies should document on an annual basis the measures they had adopted to implement real equality between women and men, notably in terms of salary. On 7 October 2004, during the debate on her initiative in the National Council, she made explicit references to the Norwegian model:

If you follow my parliamentary initiative, that would not make Switzerland a special case. Similar laws have been proposed by the governments in Norway and Sweden and are in preparation. Norway is the country where this implementation is most advanced. The Norwegian government - nota bene a bourgeois government - is proposing to increase the proportion of women in state enterprises and public limited companies in this area to at least $40 \%$. If a company does not comply with this requirement, it will be refused entry in the commercial register. I do not go that far with my parliamentary initiative. The Norwegian government introduces this law, even though women are already much better represented on management committees and boards of directors there than in Switzerland.

(National Council, 2004) $^{3}$ 
In her declaration, Teuscher thus invoked Norway as the most genderprogressive country and a forerunner in terms of equality in the private sector on the basis of the initiative to introduce female quotas for corporate boards that was currently underway there. Interestingly, she pointed out that Norway had a 'bourgeois government', like Switzerland, but that at the same time it was performing better in this area than Switzerland, as though she was anticipating opposition from the country's right-wing parties. However, as the quote shows, she also made clear that she did not want to go as far as the Norwegian government in relation to sanctions - that is, forced dissolution of companies that did not comply with the law. Even if the aim of these comments was essentially to convince and reassure the right-wing majority, her remarks implicitly presented Norway as being too progressive. The majority of the National Council's Committee on Legal Affairs, which was responsible for examining Franziska Teuscher's initiative, agreed that women were under-represented in public limited companies but claimed that quotas were not an appropriate means of achieving gender equality in the business realm and refused to adopt legal provisions restricting the sphere of autonomy of companies. The National Council followed the Committee's recommendations and refused to act on Teuscher's initiative by a large majority.

In June 2003, a few months after Teuscher's first initiative, Barbara Haering launched a similar, though more modest, parliamentary initiative calling for an increase in the proportion of women on the boards of state-owned firms through an amendment to the existing law on public limited companies included in the Swiss Code of Obligations. Representing the Socialist Party, Haering argued that women were still under-represented in the management of these companies, and that the state had a duty to encourage the presence of women at least in the boards of corporations in which it was itself a shareholder. Haering argued that Norway offered 'a good example' of 'an appropriate quota' to achieve this goal, although she proposed a quota of $30 \%$ instead of $40 \%$ (Parliament of Switzerland, 2003). In this sense, the early proponents of a measure to increase female board membership were imaging Norway as a country that was very progressive, but perhaps overly so, and thus an example that could only be followed to a certain extent. For instance, during the parliamentary debate on Haering's proposition, Susanne Leutenegger Oberholzer, a Socialist member of the National Council, defended Haering's initiative by arguing that it was very 'moderate' in comparison to measures taken by other countries that had gone much further, such as Norway, whose legislation had stipulated a higher quota for women and included private companies (National Council, 2005). By a very small majority, the National Council decided on March 2005 to proceed with the initiative, and a subcommittee was instructed to draw up a preliminary legislative draft.

A few years later, in June 2007, Teuscher re-entered the dispute with a question addressed to the Federal Council about the presence of women 
in corporate boardrooms. She claimed that Switzerland was still 'lagging behind' Norway, Sweden and 'even' Great Britain. In the following extract, the 'Nordic exceptionalism' with regard to policy innovation in the field of gender equality is clearly invoked, along with the specific position of Norway, which is described as being the most advanced country in this area:

Several studies have assessed the place of women in the world of work. The conclusions are disappointing: with the exception of the Nordic countries, which have put in place targeted measures to support women's career prospects, the number of women on boards of directors seems destined to remain modest. Committed to improving diversity and promoting equal opportunities, Norway - which ranks first in terms of the proportion of women in the economy - has taken a further step by introducing quotas for the boards of directors of the 650 largest publicly traded companies.

(Federal Council, 2007) $^{4}$

In June 2008, the preliminary legislative draft initiated by the National Council in 2005 was narrowly rejected by the same National Council, which followed the recommendation made by the National Council's Committee on Legal Affairs on Haering's proposition. The main arguments against the draft were as follows: choices regarding the members of a board of directors should be made in complete independence and should solely be based on the company's requirements; the proposed quotas represented excessive state interference in the economy; quotas would put public-sector companies at a disadvantage compared to the private sector; and quotas entailed the risk that a woman might be appointed because of her gender rather than because of her competencies. Finally, a majority of the Committee's members were opposed to the idea of using legislation as a tool to pursue an 'ideological project' and claimed that gender quotas were not an appropriate means of achieving gender equality (Committee on Legal Affairs, 2008). Thus, during the first debates in the Swiss parliament, proponents of the quota system mostly women - were repeatedly using the Nordic countries, and Norway in particular, to call into question the Swiss system, which was described in comparison as being much more 'traditional', and by implication more conservative. ${ }^{5}$ They failed, however, to convince their opponents, who mainly denounced quotas as an undesirable state intervention in the economy.

\section{The financial crisis as a turning point}

The 2007-2008 financial crisis gave a new impulse to the debate on female business quotas in Switzerland and led to a shift in how the Norwegian model was perceived by the proponents of a quota system. After the failure of the two parliamentary initiatives proposed by Franziska Teuscher and Barbara Haering, Maria Roth-Bernasconi, a Socialist member of the 
National Council, took advantage of the crisis to submit in December 2008 a new initiative to introduce gender quotas of $30 \%$ for each gender in both state-owned firms and public limited companies. Unlike her predecessors, Roth-Bernasconi did not mention the Nordic countries. Her argument was to denounce predominantly male corporate boards, which, according to her, 'drove the companies into bankruptcy because they were only concerned about their own profits' (Parliament of Switzerland, 2008). However, during the parliamentary session of September 2009, a proponent of the RothBernasconi initiative, who was also member of the Socialist Party, again mentioned Norway as an example to be followed. Once more, the initiative met with strong opposition from the right-wing majority in the parliament, who largely rejected it. Two new arguments were put forward against quotas by Oskar Freysinger, a member of the National Council from the Swiss People's Party, the right-wing populist party that was the largest party in the Federal Assembly at the time. Freysinger claimed that many women were not interested in sitting on corporate boards and should not be forced to fill quotas. Moreover, according to him, a quota system would put Swiss firms in unfair competition with foreign companies listed on the Swiss stock exchange and not subject to a similar regulation (National Council, 2009b). He thus denounced quotas as a measure that not only went against the principles of economic freedom and free competition, but also went against the interests of women themselves, insinuating that they would be forced to sit on boards of directors against their will - a type of rhetoric similar to that used by his party a few decades earlier to argue against women's suffrage, suggesting that such a stance was allegedly for their own good (see Studer, 1996: 372-374).

In March 2009, Katharina Prelicz-Huber, a member of the National Council representing the Green Party, once again raised the issue of the insufficient presence of women on the boards of directors of Swiss firms through a motion addressed to the Federal Council that argued in favour of a legal solution based on the Norwegian model. Prelicz-Huber declared that 'Norway is setting an example here; in particular, it has a system of sanctions for non-compliance with these requirements' (National Council, 2009a). ${ }^{6}$ Two years later, in March 2011, she made the following statement about the adoption of quotas in Norway during the parliamentary session discussing her motion:

The model country of Norway proves that it works. The claim in Norway did not come from a leftist woman, but from a bourgeois man. He made the move for economic reasons, because there was a need for well-educated women, and otherwise it would take too long.

(National Council, 2011) ${ }^{7}$

Prelicz-Huber did not specify in her speech which 'bourgeois man' she was referring to. The important point here is that her argument generally echoed 
the discourse of a rising liberal feminism that, in the wake of the 2007-2008 financial crisis, increasingly claimed that women represented 'untapped resources' for business (Roberts, 2012). Susanne Leutenegger Oberholzer went a step further in September 2012 when she proposed two parliamentary initiatives to increase the membership of women on the boards of corporations listed on the Swiss stock exchange or with close ties to the Confederation to at least $40 \%{ }^{8}$ The proposals also included a stipulation that if corporations failed to comply with the initiative, they would have to withdraw from the stock exchange. Her proposals were thus clearly inspired by the Norwegian system of sanctions. In her initiative covering corporations listed on the Swiss stock exchange, Leutenegger Oberholzer quoted a study made by the previously mentioned consulting firm Egon Zehnder that showed that the 'Nordic countries' - namely, Norway, Finland and Sweden - were above the European mean in relation to female membership of corporate boards, while other countries such as Italy, Austria, Luxembourg and Portugal were lagging behind (Parliament of Switzerland, 2012). In so doing, she was using the status of women to evaluate and rank the performances of states on equality in a hierarchical manner (see Towns, 2009, 2010). During the parliamentary debate on Leutenegger Oberholzer's initiative in December 2013, Mathias Reynard, also a Socialist member of the National Council, claimed that Norway, a 'pioneer country in this field', had made 'impressive' progress thanks to the introduction of quotas, and that France, a neighbouring country of Switzerland, had also just adopted a similar system (National Council, 2013b).

As these different examples show, the financial crisis thus contributed to a change in the use of Norway's image by the advocates of a quota system. Indeed, as we have seen, the first interventions by the Greens and the Socialists invoked Norway as a forerunner and an example to be followed, but only partially. They thus created, in the end, an image of a Norway that was almost too progressive, even if such a judgement was never stated explicitly. After the financial crisis, the promoters of a quota system, who were still drawn from the Green and Socialist parties, increasingly created the image of an 'exemplary Norway' in the sense that the latter was portrayed as a forerunner and a reasonably progressive country. Once more, however, the different initiatives were rejected by a large majority in the National Council.

\section{Sweden as alternative}

For the first ten years, the debate on gender inequality in corporate boards took place mainly in the arenas of the Federal Assembly and was marked by the repeated failures of the various quota initiatives. The next phase began with the decision of the Swiss Federal Council in November 2013 to increase the presence of women on the boards of directors of the large firms with close ties to the Confederation (Federal Council, 2013). The aim was to set 
a target quota of $30 \%$ of each gender by 2020 . Such a proposal had been first put forward during the parliamentary debates on Susanne Leutenegger Oberholzer's initiatives (see above) without arousing any particular opposition. In December 2013, the Liberal-Green parliamentary group submitted a motion at the National Council through the intervention of Kathrin Bertschy, asking the Federal Council to "impos[e] the "apply or explain" principle to combat sex discrimination in employment' in companies listed on the Swiss stock exchange (National Council, 2013a). By adopting such an approach, the Liberal-Green group was proposing a measure that was in fact softer than that of quotas and followed the Swedish model:

While in Switzerland fixed quotas are seen as an excessive infringement of economic freedom and are therefore unlikely to be adopted, the fact remains that the previously favoured voluntary measures have hardly moved the lines. We therefore call for companies listed on the stock exchange to be obliged to comply with a model based on the principle of 'apply or explain', in order to gradually eliminate the gender discrimination that still prevails in the labour market, as Sweden has done, not without success.

(National Council 2013a) ${ }^{9}$

Sweden, which until then had been invoked far less frequently in the debates, thus appeared as an alternative to the Norwegian model, which was perceived as too restrictive by opponents of the quota system. The Federal Council proposed to reject the motion but pledged that it would reflect on the issue. Two years later, the Federal Council launched a project to reform the legislation on public limited companies. Among other things, the reforms would introduce gender quotas for these companies, aiming to ensure that women would constitute $30 \%$ of the membership of their boards of directors and $20 \%$ of their executive boards by 2020 (Federal Council, 2015). Although no sanctions were planned in the event of non-compliance, the issue remained highly sensitive and led to passionate debates both in and outside the parliament. Within the parliament, the project was mostly supported by the Greens and the Socialists - who had been in favour of some form of quota from the start - and opposed by members of the RadicalLiberal Party and the Swiss People's Party. Proponents of quotas continued to cite Norway as an example to be followed. For example, the Federal Commission for Women's Issues published in March 2014 a declaration in favour of gender quotas that would seek to bring about a level of $40 \%$ for women's membership of the boards of directors and $33 \%$ for the executive direction of state-owned companies, companies listed on the stock exchange and companies with more than 250 employees (Federal Commission for Women's Issues, 2014). Moreover, the Commission spoke in favour of sanctions should companies fail to respect these objectives. In the working document that led to this declaration, elaborated by Regula Kägi-Diener (2014: 3, 17), several 
references were made to Norway, pointing out that the Norwegian example had led to discussions all over Europe about the relevance of legal requirements in efforts to improve the presence of women on corporate boards and declaring that Norway 'was leading the world' on these issues.

The Federal Council's reform project provoked a general outcry among business circles, and notably the Swiss Employers Confederation. Already in December 2012, the latter had published in collaboration with Economiesuisse, the major Swiss business interest association, a report that argued in favour of more women among leading positions in Swiss firms, but against quotas (Swiss Employers Confederation and Economiesuisse, 2012). Interestingly, the report explicitly contrasted the Norwegian model with the Swedish one. It accused the former of having favoured the accumulation of mandates by a small number of women, which was viewed as contravening principles of good corporate governance. In raising this point, it echoed the criticism voiced by some Norwegian scholars who claimed that the introduction of quotas in Norway had led to the development of a female elite holding multiple board positions, dubbed the 'golden skirts' (see, for example, Huse, 2012: 17). ${ }^{10}$ Moreover, the report pointed to the fact that only $5 \%$ of the chairpersons of the boards of Norwegian corporations were women. In the end, the Swiss Employers Confederation and Economiesuisse thus depicted the Norwegian model as elitist, rather than progressive. By contrast, Sweden was presented as a successful model and an example of the efficiency of voluntary measures.

In 2018, the Swiss Employers Confederation repeated its attacks against the Norwegian system of sanctions. In addition to the above-mentioned arguments, it criticized the fact that the numbers of women within middle management had not increased, which was regarded as a failure of a quota system that favoured only a small elite circle:

The Swiss Employers Confederation is opposed to the inscription in the law of quotas for women in positions of responsibility... [Norwegian] quotas have not resulted in the expected results... [no] increase in the pool of potential candidates in the middle management population and [few] women [have] been allocated additional directorships.

(Swiss Employers Confederation, 2018) ${ }^{11}$

This argument, however, showed either a misunderstanding or a wilful misrepresentation of the Norwegian measures and was therefore fallacious, as the latter were not intended to increase the share of women in business management - unlike the Federal Council's plan, which aimed at $20 \%$ of women on executive boards. It is true, though, that Norwegian quotas for corporate boards did not lead to more gender equality in senior management positions (Teigen, 2018: 350-351). The denunciation of a 'massive interference' and the comparison with Norway was thus undoubtedly abusive, since, again, no sanctions were envisaged in the Federal Council's project. 
Norway was therefore mobilized above all as a symbol of an undesirable state intrusion into the economy and contrasted with the approach of a more liberal Sweden. In order to avoid such an intrusion, the Swiss Employers Confederation tried to instil fear in its audience, claiming that several Norwegian firms had withdrawn from the stock exchange in order to escape from the quotas.

In June 2018, despite the strong opposition from the private sector, the National Council finally ratified the Federal Council's proposal for a reform of the law on public limited companies by a narrow margin, with 95 votes in favour, 94 against, and 3 abstentions. A few days after the women's strike of 14 June 2019, which was itself a historical moment owing to its magnitude, the Council of States, in turn, ratified the project. The Federal Council's proposal has certainly benefited from the changing international context, marked by the gradual adoption of quotas in many Western countries, the financial crisis that - temporarily - called the capitalist system into question and the new rise of the women's movement. It should be remembered, however, that the measures proposed by the Federal Council remained very moderate in comparison with those adopted by Norway or France since they did not include any sanctions in the event of non-compliance.

\section{Conclusion}

Since the Swiss debate on female business quotas began in the early 2000s, both supporters and opponents of the quota system have compared Switzerland with other European countries. Both frequently drew on the representation of the Nordic countries more than that of other countries, thus confirming the competing role of Norwegian and Swedish gender-quota policies in the Swiss debates on gender quotas. During the early phase of the debate, which began with the first discussions in parliament in 2003 and continued until the outbreak of the 2007-2008 financial crisis, the various parliamentarians - mainly women from the Green and the Socialist parties who were arguing in favour of quotas made frequent references to Norway to plead their case. Interestingly, they depicted it as a progressive country and a forerunner, and thus as an example to be followed - but only to a certain extent, as they did not want to go as far as the Norwegian government in terms of sanctions or the quota level. Although this was probably essentially a strategy to persuade and reassure the right-wing majority, the early proponents of a quota system implicitly gave the impression that Norway was too progressive - at least compared to Switzerland. The financial crisis of 20072008 contributed to a shift in this perception, and the proponents of female quotas for board membership gradually aligned with the Norwegian system.

For ten years, the debates on the quota system remained essentially confined to the Swiss parliament, and Norway was clearly the country most mentioned by the proponents of such a system, along with Sweden to a lesser extent. France, for example, was also cited but less often, even after 
the introduction of the Copé-Zimmermann Law in January 2011. The Nordic countries, and in particular Norway, thus served as the main reference points for policy innovation in the field of gender equality, in both the Swiss and French debates on quotas (for the French case, see Singh et al., 2015). All interventions in favour of some form of quota were blocked by the rightwing majority, which was strongly opposed to any state interference in the economy.

The November 2013 decision of the Swiss Federal Council to increase the presence of women on the boards of directors of large firms with close ties to the Confederation made the threat of such an intervention concrete and contributed to a transformation of the debate. It led major employers' organizations, such as Economiesuisse and the Swiss Employers Confederation, to take a stand against any non-voluntary measures, lining up with the right-wing parties. Switzerland's business circles launched repeated attacks against the Norwegian model, pointing to its failures. They claimed that the introduction of quotas had benefited only a small female elite holding multiple board positions - the 'golden skirts'-invoking the image of a country ultimately favouring an elitist rather than progressive system. In order to circumvent the threat of quotas, business organizations directed attention to Sweden's voluntary system, although there are considerable differences between Switzerland and Sweden in terms of measurements of gender equality. In both countries, however, the principle of self-regulation and noninterference of the state in the business sector prevailed over gender-equality values. In the end, analysis of the Swiss debate on female quotas for corporate boards shows that the Nordic countries have constantly remained a point of reference, whether presented as a model to be followed or one to be avoided. Whereas Norway at first was a model to imitate, right-wing politicians later mobilized it as a symbol of an undesirable state intrusion into the economy and contrasted it with the approach of a more liberal Sweden.

\section{Notes}

1 See, for example, the website of Catalyst at www.catalyst.org.

2 A question can be addressed by a member of parliament to the Federal Council in order to request information about important domestic or foreign affairs. The Federal Council must reply in writing by the next session. A postulate mandates the Federal Council to examine and report on whether to submit a bill to the Federal Assembly or to adopt a particular measure. It may be submitted by the majority of the members of a parliamentary committee, by a parliamentary group or by an individual member of parliament. The postulate is accepted as soon as it has been approved by one of the councils. A motion instructs the Federal Council to submit a bill to the Federal Assembly or to adopt a particular measure. As with the postulates, motions can be submitted by the majority of the members of a parliamentary committee, by a parliamentary group or by an individual member of parliament. Motions must be accepted by both councils. A council member, a parliamentary group or a parliamentary committee can use a parliamentary initiative to propose a draft version of new legislation or the terms of such legislation. A committee of the National Council or Council of 
States is given responsibility for the legislative work (definitions according to the online lexicon of parliamentary terms; see Parliament of Switzerland, n.d.).

3 Author's translation from the original German.

4 Author's translation from the original French.

5 The term was employed by Franziska Teuscher in her question (07.1072) addressed to the Federal Council on 21 June 2007.

6 Author's translation from the original French.

7 Author's translation from the original German.

8 Already in March 2004, Susanne Leutenegger Oberholzer had deposited a parliamentary initiative (04.412) entitled 'Gender reporting pour les sociétés cotées en bourse', arguing in favour of gender reporting in listed companies, which was rejected by the National Council.

9 Author's translation from the original French.

10 Norwegian corporate boards do not set limits on the number of board seats an individual person can hold, unlike France, for example, where there is a limit of a maximum of five seats (Takagi and Gröschl, 2012: 4).

11 Author's translation from the original French.

\section{References}

Adams RB and Ferreira D (2009) Women in the boardroom and their impact on governance and performance. Journal of Financial Economics 94(2): 291-309.

Agustín LR, Siim B and Borchorst A (2018) Gender equality without gender quotas. In: Lépinard E and Rubio-Marín R (eds) Transforming Gender Citizenship: The Irresistible Rise of Gender Quotas in Europe. Cambridge: Cambridge University Press, 400-423.

Committee on Legal Affairs (2008) Report of the Committee on Legal Affairs to the National Council on Haering parliamentary initiative (03.440), 3 April 2008. Available at: https://www.parlament.ch/centers/kb/Documents/2003/Rapport_ de_la_commission_CAJ-N_03.440_2008-04-03.pdf (accessed 13 January 2019).

Danielsen H and Larsen E (2015) Likestillingslandet Norge 1990-2013. In: Danielsen H, Larsen E and Owesen IW (eds) Norsk likestillingshistorie. Bergen: Fagbokforlaget, $186-219$.

Egon Zehnder (2018) 2018 Global Board Diversity Tracker: Who's Really on Board? Available at: https://www.egonzehnder.com/global-board-diversity-tracker/ tracker-highlights (accessed 10 January 2020).

Erlingsdóttir I (2021) Trouble in paradise? Icelandic gender-equality imaginaries, national rebranding and international reification. In: Larsen E, Moss SM and Skjelsbæk I (eds) Gender Equality and Nation-Branding in the Nordic Region. Abingdon: Routledge, 000-000.

Federal Commission for Women's Issues (2014) Oui aux quotas de genre dans l'économie. Prise de position de la Commission fédérale pour les questions féminines. 10 March. Available at: https://www.ekf.admin.ch/ekf/fr/home/documentation/ prises-de-position.html (accessed 8 June 2018).

Federal Council (2007) Question addressed by Franziska Teuscher (07.1072) to the Federal Council on 21 June 2007, 'Part des femmes dans les conseils d'administration et les directions'. Available at: https://www.parlament.ch/fr/ratsbetrieb/ suche-curia-vista/geschaeft?AffairId=20071072 (accessed 29 December 2018).

Federal Council (2013) Directives sur la représentation des communautés linguistiques et des sexes dans les organes de direction suprêmes des entreprises proches 
de la Confédération. Press release, 6 November. Available at: https://www.admin. ch/gov/fr/accueil/documentation/communiques.msg-id-50856.html (accessed 8 July 2018).

Federal Council (2015) Grandes lignes du projet de révision du droit de la société anonyme. Press release, 12 December. Available at: https://www.ejpd.admin.ch/ ejpd/fr/home/aktuell/news/2015/2015-12-04.html (accessed 8 July 2018).

Fraisse G and Perrot M (2002) Ordres et libertés. In: Duby G and Perrot M (eds) Histoire des femmes en Occident, Tome IV: Le XIXe siècle. Paris: Perrin, 11-18.

Freidenvall L (2018) Gender equality without legislated quotas in Sweden. In: Lépinard E and Rubio-Marín R (eds) Transforming Gender Citizenship: The Irresistible Rise of Gender Quotas in Europe. Cambridge: Cambridge University Press, 366-399.

Ginalski S (2020) Who runs the firm? A long-term analysis of gender inequality on Swiss corporate boards. Enterprise \& Society. Epub ahead of print, 2 March 2020. DOI: https://doi.org/10.1017/eso.2019.64.

Goldeng ELB and Huse M (2017) A snowball started rolling: Lessons from Norway about gender quotas on boards. hrzone.com, 11 January. Available at: https:// www.hrzone.com/lead/future/a-snowball-started-rolling-lessons-from-norwayabout-gender-quotas-on-boards (accessed 6 April 2018).

Heemskerk E and Fennema M (2014) Women on board: Female board membership as a form of elite democratization. Enterprise \& Society 15(2): 252-284.

Hoel M (2008) The quota story: Five years of change in Norway. In: Vinnicombe S, Singh V, Burke RJ, Bilimoria D and Huse M (eds) Women on Corporate Boards of Directors. Cheltenham \& Northampton, MA: Edward Elgar, 79-87.

Huse M (2012) The 'golden skirts': Lessons from Norway about women on corporate boards of directors. In: Gröschl S and Takagi J (eds) Diversity Quotas, Diverse Perspectives: The Case of Gender. Farnham: Gower, 11-23.

Kägi-Diener R (2014) Des quotas de femmes dans les cercles dirigeants de l'économie. Working document produced under mandate from the Federal Commission for Women's Issues. March 2014. Available at: https://www.ekf.admin.ch/ekf/fr/ home/documentation/etudes-et-recommandations.html (accessed 8 June 2018).

Lépinard E and Rubio-Marín R (2018) Introduction. In: Lépinard E and Rubio-Marín R (eds) Transforming Gender Citizenship: The Irresistible Rise of Gender Quotas in Europe. Cambridge: Cambridge University Press, 1-38.

Mach A, David T, Ginalski S and Bühlmann F (2021) From quiet to noisy politics: Transformation of Swiss business elites' power. Politics and Society 49(1): 17-41.

National Council (2004) Debate on parliamentary initiative by Franziska Teuscher (03.412), 'Mehr Frauen in die Leitungen von Aktiengesellschaften'. Fall Session 2004, 16th Session, 7 October. Available at: https://www.parlament. $\mathrm{ch} / \mathrm{fr} / \mathrm{ratsbetrieb/amtliches-bulletin/amtliches-bulletin-die-verhandlungen?}$ SubjectId=7624 (accessed 8 June 2018).

National Council (2005) Debate on parliamentary initiative by Barbara Haering (03.440), 'Mehr Frauen in Verwaltungsräten von Gesellschaften mit Bundesbeteilungen'. Spring Session 2005, 2nd Session, 1 March. Available at: https:// www.parlament.ch/fr/ratsbetrieb/amtliches-bulletin/amtliches-bulletin-dieverhandlungen?SubjectId=25687 (accessed 13 January 2019).

National Council (2009a) Motion addressed by Katharina Prelicz-Huber (09.3067) to the National Council on 3 March 2009, 'Représentation des femmes dans les conseils d'administration'. Available at: https://www.parlament.ch/fr/ratsbetrieb/ suche-curia-vista/geschaeft?AffairId=20093067 (accessed 8 June 2018). 
National Council (2009b) Debate on parliamentary initiative by Maria RothBernasconi (08.510), 'D'avantage de femmes dans les conseils d'administration'. Fall Session 2009, 14th Session, 23 September. Available at: https://www.parlament. $\mathrm{ch} / \mathrm{fr} / \mathrm{ratsbetrieb/amtliches-bulletin/amtliches-bulletin-die-verhandlungen?Subjec-}$ tId=17856 (accessed 13 January 2019).

National Council (2011) Debate on motion by Katharina Prelicz-Huber (09.3067), 'Représentation des femmes dans les conseils d'administration'. Spring Session 2011, 4th Session, 2 March. Available at: https://www.parlament.ch/fr/ratsbetrieb/ amtliches-bulletin/amtliches-bulletin-die-verhandlungen?SubjectId=23475 (accessed 13 January 2019).

National Council (2013a) Motion addressed by the Liberal-Green group (13.4285) to the National Council on 13 December 2012, 'Imposer le principe "appliquer ou expliquer" pour lutter contre la discrimination fondée sur le sexe en matière d'emploi'. Available at: https://www.parlament.ch/fr/ratsbetrieb/suche-curia-vista/ geschaeft?AffairId=20134285 (accessed 13 January 2019).

National Council (2013b) Debate on parliamentary initiative by Susanne Leutenegger Oberholzer (12.469), 'Proportion équilibrée entre les hommes et les femmes au sein des conseils d'administration des entreprises cotées en bourse. Modification de la loi sur les bourses'. Winter Session 2013, 11th Session, 11 December. Available at: https://www.parlament.ch/fr/ratsbetrieb/amtliches-bulletin/amtlichesbulletin-die-verhandlungen?SubjectId=23492 (accessed 13 January 2019).

Parliament of Switzerland (n.d.) Lexicon of parliamentary terms. Available at: https://www.parlament.ch/en/über-das-parlament/parlamentswörterbuch (accessed 10 January 2019).

Parliament of Switzerland (2003) Parliamentary initiative by Barbara Haering (03.440) submitted on 20 June 2003, 'Mehr Frauen in Verwaltungsräten von Gesellschaften mit Bundesbeteilungen'. Available at: https://www.parlament.ch/fr/ratsbetrieb/ suche-curia-vista/geschaeft?AffairId=20030440 (accessed 8 June 2018).

Parliament of Switzerland (2008) Parliamentary initiative by Maria Roth-Bernasconi (08.510) submitted on 17 December 2008, 'D'avantage de femmes dans les conseils d'administration'. Available at: https://www.parlament.ch/fr/ratsbetrieb/suchecuria-vista/geschaeft?AffairId=20080510 (accessed 13 January 2019).

Parliament of Switzerland (2012) Parliamentary initiative by Susanne Leutenegger Oberholzer (12.469) submitted on 26 September 2012, 'Proportion équilibrée entre les hommes et les femmes au sein des conseils d'administration des entreprises cotées en bourse. Modification de la loi sur les bourses'. Available at: https://www.parlament.ch/ fr/ratsbetrieb/suche-curia-vista/geschaeft?AffairId=20120469 (accessed 8 June 2018).

Post C and Byron K (2015) Women on boards and firm financial performance: A meta-analysis. Academy of Management Journal 58(5): 1546-1571.

Prügl E (2012) 'If Lehman Brothers had been Lehman Sisters...': Gender and myth in the aftermath of the financial crisis. International Political Sociology 6(1): 21-35.

Roberts A (2012) Financial crisis, financial firms... and financial feminism? The rise of 'transnational business feminism' and the necessity of Marxist-feminist IPE. Socialist Studies/Études socialistes 8(2): 85-108.

Schulz P (1994) Une combinaison délétère, ou la néfaste interaction pour les femmes $\mathrm{du}$ droit public et du droit privé, en droit suisse. In: Jost HU, Pavillon M and Valloton $\mathrm{F}$ (eds) La politique des droits. Citoyenneté et construction des genres aux 19 e et 20 e siècles. Paris: Kimé, 129-144.

Sineau M (2002) Droit et démocratie. In: Duby G and Perrot M (eds) Histoire des femmes en Occident, Tome 5: Le XXe siècle. Paris: Perrin, 631-665. 


\section{Stéphanie Ginalski}

Singh V and Vinnicombe S (2004) Why so few women directors in top UK boardrooms? Evidence and theoretical explanations. Corporate Governance 12(4): 479-488.

Singh V, Point S and Moulin Y (2015) French supervisory board gender composition and quota threat: Changes from 2008 to 2010. Gender in Management: An International Journal 30(7): 551-571.

Studer B (1996) 'L'Etat c'est l'homme': politique, citoyenneté et genre dans le débat autour du suffrage féminin après 1945. Revue Suisse d'histoire 46(3): 356-382.

Swiss Employers Confederation (2018) Quotas de femmes: la mauvaise voie pour arriver au bon résultat. 22 May. Available at: https://cdn.arbeitgeber.ch/production/ uploads/2018/05/20180522-Position-Frauenquote_f.pdf (accessed 22 July 2020).

Swiss Employers Confederation and Economiesuisse (2012) Des objectifs et non des quotas, pour plus de femmes dirigeantes! 17 December. Available at: https:// www.economiesuisse.ch/sites/default/files/dossier_pdf/2012-12-17_DP_quotas_ femmes.pdf (accessed 22 July 2020).

Takagi J and Gröschl S (2012) Introduction: Gender quotas in management. In: Gröschl S and Takagi J (eds) Diversity Quotas, Diverse Perspectives: The Case of Gender. Farnham: Gower, 1-7.

Teigen M (2018) The 'natural' prolongation of the Norwegian gender equality policy institution. In: Lépinard E and Rubio-Marín R (eds) Transforming Gender Citizenship: The Irresistible Rise of Gender Quotas in Europe. Cambridge: Cambridge University Press, 341-365.

Towns A (2009) The status of women as a standard of 'civilization'. European Journal of International Relations 15(4): 681-706.

Towns A (2010) Women and States: Norms and Hierarchies in International Society. Cambridge: Cambridge University Press.

Vinnicombe S, Singh V, Burke RJ, Bilimoria D and Huse M (eds) (2008) Women on Corporate Boards of Directors. Cheltenham \& Northampton, MA: Edward Elgar. 


\title{
8 Silenced at the border

\author{
Norwegian gender-equality \\ policies in national branding
}

\author{
Cathrine Holst and Mari Teigen
}

Creating a national brand might entail a polished version of realities and facts on the ground. Branding is, after all, image-building. How, then, are Norwegian gender-equality policies presented in national image-making? In this chapter, we investigate how the national branding of Norway takes form through the voicing and silencing of various features of Norwegian gender-equality policies. Gender-equality policy is a hybrid policy field that encompasses a range of different areas. The emphasis here will be on what we have identified as the four main areas of Norway's gender-equality policies: equality legislation, work-life balance, gender mainstreaming and gender balance in decision-making (Skjeie et al., 2019). ${ }^{1}$

We base our analysis on the Norwegian Ministry of Foreign Affairs' most recent action plan on gender equality, together with selected speeches by the minister of foreign affairs and the minister of children and equality. We view these documents as core sites of communication to foreign audiences on Norwegian gender-equality policies and ask how their main messaging relates to existing knowledge about the features, merits and shortcomings of these policies. Our primary focus is the Norwegian Ministry of Foreign Affairs' Action Plan for Women's Rights and Gender Equality in Foreign and Development Policy 2016-2020, entitled Freedom, Empowerment and Opportunities (hereafter: 'Action Plan') (MFA, 2016a), the ministry's most important communication document on gender equality. In addition, two other documents contribute to framing the main messaging articulated in this Action Plan: first, the speech by former minister of foreign affairs Børge Brende (2013-2017) at the launch of the Action Plan (MFA, 2016b); second, the statement by former minister of children and equality Linda Hofstad Helleland (2018-2019) at the 62nd session of the Commission on the Status of Women (CSW) (Norwegian Ministry of Children and Equality, 2018). These two statements are both thematically relevant and were made on prominent occasions. They therefore serve as central additional instances of branding, and the issues that are highlighted within them overlap overall with the focus and priorities of the Action Plan.

The question we ask is how Norway recommends gender-equality approaches and policy solutions abroad, and to what extent perspectives and 
solutions promoted internationally take on board existing analyses of Norway's own experiences and policy challenges. A central finding in our analysis is that the branding abroad of Norwegian gender-equality policies in some important respects disregards our knowledge of the limitations and deficiencies of these policies. Further, and more surprisingly, some of the recognized strengths of Norwegian gender-equality policy are downplayed.

\section{Nordic gender equality in nation-branding}

A key insight from studies of nation-branding is that 'branding matters'. The aim of different nation-branding strategies is to influence how countries are perceived by both state- and non-state actors in the international community. Such branding efforts aim to influence macro-economic variables (GDP, exports, etc.) or diplomatic relations (see, for example, Fan, 2005). However, they may also shape citizens' perceptions of their own country and ideas of what, for instance, the 'welfare state' or 'gender equality' refer to and ought to imply at home (Danielsen et al., 2015; Marklund, 2017). A country's economic, political and cultural position in the international system, as well as a government's standing among its own citizens, is thus not straightforwardly given by some objective circumstances. A nation's status is also shaped by less tangible means, such as image-building, both at home and abroad.

Effective branding, however, needs to correspond with certain agreedupon realities to be credible. For example, when countries in the Nordic region find it useful to brand themselves as gender-equality forerunners (see, for example, Towns, 2017; Jezierska and Towns, 2018), this image-building is supported by the fact that these countries top international gender-equality indexes and the number of people living 'gender equal' lives within them tends to be greater than that in other regions. A successful branding strategy is based on comparative advantages - for example, in relation to levels of environmental pollution or a country's record on human rights or gender equality (see, for example, Fetscherin, 2009, and Chapter 9 in this volume by Hellum) - and on toning down any possible shortcomings. But to what extent do we find this simple pattern of over-emphasizing achievements and covering up flaws when we examine the treatment of Norwegian gender-equality policies in the country's national branding?

There are several existing and ongoing studies of the role of gender equality and gender-equality policy in the national branding strategies of the countries of the Nordic region. These studies find, first, that internal controversies spurred by mobilization and policies for gender equality in the Nordic countries are toned down or silenced. Such controversies include conflicts between Nordic gender-equality ideology and multiculturalism, or attacks on 'feminism' coming from the populist right - for example, Sweden's Democrats (see Towns, 2017). Second, some studies have highlighted 
how the notion of gender equality brought to the fore in Nordic nationbranding as 'Swedish' or 'Norwegian' is not necessarily progressive, but diplomatic and 'tamed' (see Towns, 2002; Tryggestad, 2014; Moss, 2017; Jezierska and Towns, 2018; Skjelsbæk and Tryggestad, 2018, 2019), in the sense that more radical features of the feminist agenda are downplayed. For example, more fundamental questioning of gender and sexuality categories and societal power relations remains unmentioned. Third, historical legacies and national self-conceptions developed over time about Nordic countries as champions of women's rights (Danielsen et al., 2015), but also about Nordic gender, including 'Nordic masculinity' (Syse, 2017), play a central role in establishing the trajectories and legacies of gender-equality policies. In our analysis, we relate our findings to these existing contributions, but also pursue a reading inspired by postcolonial feminist theory.

\section{Slippage between home and abroad}

The Nordic countries have been portrayed as 'nirvanas' of gender equality (Lister, 2009) or - more soberly - as a group of countries more characterized by equality than others (Walby, 2004, 2009). However, gender-equality policy and discourse in the Nordic countries has also been accused of tending to ignore plurality, diversity and individual autonomy (Holst, 2002; Borchorst and Siim, 2016; Martinsson et al., 2016). Nonetheless, the four areas of gender-equality policy outlined above have been recognized as pivotal policy innovations originating in the Nordic countries (Skjeie et al., 2019).

As for Norway, our focus in this chapter, the country has, first, welldeveloped equality legislation, which was primarily home-grown in the early period but in recent years has been widened and advanced as an effect of the integration of EU law and UN frameworks. Although there is variation between them, the Nordic countries share clear similarities, with Norway and Sweden being the most alike, as their equality legislation, enforcement and monitoring have developed in tandem, while Finland and then Iceland were latecomers who have subsequently levelled up with the other Nordic countries. Generally, Denmark deviates, having the least developed and most restrictive approach to equality legislation, enforcement and monitoring (Borchorst et al., 2012). Still, there are significant limitations in the monitoring and enforcement system in Norway, as well as in the other Nordic countries. Second, welfare-state services and benefits that enable parents to combine work and family life have contributed to high levels of female employment in Norway. Nevertheless, the labour market remains relatively gender-segregated, and EU integration has brought to the fore new challenges, such as the risk of benefit export and discrepancies between Nordic-style family policy and the EU's equal-treatment and anti-discrimination regime. Third, gender mainstreaming is embraced in Norway in theory, but remains largely unenforced in practice. Fourth, 
and finally, quota arrangements have contributed to high levels of gender balance in political decision-making, while significant gender imbalances remain in other societal arenas, not least in the business sector.

Below, we will lay out in more detail these features of Norwegian Nordicstyle gender-equality policy before providing an assessment of how each area is addressed in communications to the outside world.

\section{Equality legislation}

Norway was an 'early achiever' in terms of legislating against gender-based discrimination: As early as in 1978, a comprehensive law on gender equality that covered 'all areas of society' was passed by the Norwegian parliament. This legislative initiative also established the world's first Gender Equality Ombud and Gender Equality Tribunal as a low-threshold mechanism. ${ }^{2}$ From the outset, Norway's gender-equality legislation combined bans on direct and indirect discrimination with regulations related to proactive advancement of gender equality. Proactive duties for state agencies and public and private employers form a central part of the country's current equality legislation. In addition, over the past two decades, advances in EU law and a stronger commitment to complying with UN requirements in the wake of the 1995 Beijing Conference have resulted in a significant broadening of legal protection against discrimination in Europe. This development has also contributed to significant changes in Norwegian equality legislation (Skjeie et al., 2017, 2019). The first Norwegian moves to legislate against discrimination on the grounds of race, ethnicity or religion were made in the late 1990s through amendments to the Work Environment Act. Comprehensive equality laws aiming to cover not just gender but also racial or ethnic origin, religion or belief, disability, age and sexual orientation - the EU's 'six strands' of anti-discrimination policy (Krizsan et al., 2012) - have had a profound impact on Norwegian gender-equality legislation enacted from 2005 onward. In relation to sexual orientation, gender identity and gender expression, comprehensive legislation was passed in 2013. The different legal provisions regarding protection against discrimination on various grounds were collected together in a new unified equality and anti-discrimination act, modelled on the initial gender-equality act, in 2017.

The low-threshold enforcement and monitoring system of the Ombud and the Tribunal entails significant limitations, however. ${ }^{3}$ For instance, very few discrimination cases have been taken to court (see Norges offentlige utredninger, 2011; see also Hellum and Blaker Strand, 2017; Ketscher, 2019). Despite recent amendments to strengthen low-threshold enforcement (see Holst, 2020), Norway's ambitious equality and anti-discrimination legislation has mainly functioned as a symbolic legal statement. Compared with broad welfare-state initiatives on public childcare and parental-leave schemes, individual and systemic discrimination have received scant attention in Norway (Skjeie et al., 2017). 
As one might expect, the importance of firm and well-developed genderequality legislation is a key point in the Action Plan (MFA, 2016a). We see this clearly in formulations that repeatedly emphasize the rights of 'girls' and 'women's rights' to 'autonomy', 'freedom', 'self-determination' and 'empowerment'. Rights to gender equality and protection from discrimination are framed as basic rights tied directly to international agreements and obligations, such as the UN human rights conventions and the UN Convention on the Elimination of all forms of Discrimination against Women, the 1995 Platform for Action at the Fourth World Conference on Women in Beijing and the UN's Sustainable Development Goals, ${ }^{4}$ as well as the EU's Charter of Fundamental Rights, anti-discrimination legislation and gender-equality programmes (MFA, 2016a: 5-7).

Within the Action Plan, Norway - or a national 'we' - is positioned at the forefront of these developments. Not only is 'our work on women's rights... based on international human rights obligations' (MFA, 2016a: 5), but Norway's membership in international organizations in which women's and human rights are promoted and developed means that these are also central arenas where 'we... contribute to international gender equality efforts', channel 'our gender equality and non-discrimination efforts' (MFA, 2016a: 7), and in different ways 'mobilize' for gender equality (MFA, 2016a: 12). The foreign minister's presentation of Norway's international role in his speech at the launch of the Action Plan gives a parallel impression: 'When it comes to gender equality,' he states, 'Norway is a superpower' and a 'global leader'. In her CSW statement, the minister of children and equality does the same by positioning Norway both as a country where 'women are given the same opportunities as men' and as a 'prosperous and gender equal country'. Norway's achievements are then contrasted with the situation in many other countries, where existing legislation does not respect gender equality and the need for protection against discrimination. The Action Plan, for example, takes up how 'formal discrimination in national legislation is still widespread, particularly in the area of family law, but also in the areas of inheritance and property law' (MFA, 2016a: 8). Similarly, when the foreign minister stresses anti-discriminatory equality legislation as a universal requirement for Norway, he comments that 'we cannot tolerate that religion, culture or traditions are used to discriminate against girls and women.... Human rights are universal. They apply to all. Everywhere. ${ }^{96}$

It should be noted, however, that the references in the branding documents to rights and legislation are generic ${ }^{7}$ and do not identify specific features of Norway's gender-equality legislation. This also means that no references are made to those features that have been central to Norwegian legislation, such as a concept of discrimination that includes both direct and indirect forms of discrimination, the role of proactive duties, and, more recently, the development of a broader corpus of anti-discrimination legislation that connects gender and other dimensions, such as ethnicity and sexuality. This general avoidance of specificity also conceals the enduring problems that we are 
familiar with in the Norwegian legislative context. These include limited implementation and enforcement, which tend to make equality legislation symbolic-legal declarations with limited real consequences.

Furthermore, whereas Norway's role as an international norm entrepreneur and norm-pusher in the international arena is mentioned repeatedly, the branding documents make no mention of instances where the EU and other international judicial frameworks have 'pushed' for amendments to Norway's equality legislation. Moreover, as conflicts between international gender-equality obligations and national legislation are framed as happening 'elsewhere', incidents in which Norway has been accused of not living up to international standards in its own legislation do not enter the picture.

Uncertainty around whether Norway's family policy is in accordance with the EU's anti-discrimination directive was tried legally in 2019 (Case E-1/18). This challenge to Norwegian policy occurred in the wake of the Maistrellis case, in which the European Court of Justice ruled that the Greek government could not deprive the father of the right to parental-leave benefit on the grounds that the child's mother was not in employment (EURLex, 2015). Similarly, Norway's parental-benefit scheme makes the father's entitlement to paid parental leave dependent on the mother being in work or education. Such requirements do not apply for the paid parental leave of the mother. In the first round of legal assessment, the European Free Trade Association Surveillance Agency (ESA) found this regulation to be in violation of the EU's equal-treatment directive. However, when Norway appealed the decision to the EFTA court, the court dismissed the case, arguing that the Norwegian parental-leave benefit scheme falls outside the scope of the directive's ban on unequal treatment in hiring and working conditions. ${ }^{8}$

Accordingly, the case of Norway vs. the EFTA court ended in favour of Norway's policy of treating mothers and fathers differently in terms of the right to use the parental-leave scheme. However, the controversy brought into question the notion of Norway as a 'global leader' in gender equality and as favouring the 'same opportunities' for women and men. Arguably, this was rather a case of the EU pushing Norway towards a more progressive stance, not the other way around, and, importantly, we find this even in the area of family policies, which have been a key pillar in the Nordic societal model (for overviews, see Skevik and Hatland, 2008; Leira, 2002, 2012; Ellingsæter, 2014).

\section{Work-life balance}

Gender-equality-oriented family policies constitute a main sub-area of Norway's gender-equality policies. Over time, a range of family- and parentfriendly services and benefits have been institutionalized in Norway. The development of publicly subsidized kindergartens, daycare centres and outof-school care has been a priority at least since the 1990s, and Norway is currently regarded as having full kindergarten coverage. Paid parental leave 
has been extended over time, and is now 49 weeks at $100 \%$ coverage (or 59 weeks with $80 \%$ coverage), where some weeks are reserved for the mother, some for the father, and some are shared. In addition, there are rights for parents to unpaid long-term leave to care for newborns and small children, a right to paid leave of absence for nursing mothers, and a right to paid leave to care for sick children. A set of special benefits for single parents is also in place. There is also a universal child-benefit scheme for anyone supporting children under the age of 18 . In addition, there are tax benefits for families and a cash-for-care benefit for parents with children that do not attend state-sponsored nurseries (Vollset, 2011).

The outcomes of these policies are high levels of female employment and a strong integration of women in higher education and the labour market in Norway. Yet, in spite of these important markers of gender-equality success, the Norwegian labour market is characterized by high levels of horizontal gender segregation - men and women concentrate in different occupations and professions - and vertical gender segregation - prevalent male dominance in top positions, which is especially evident in the business sector (Reisel, 2019).

Surprisingly, a work-life-balance perspective on the family is relatively absent in the Action Plan, with the exception of some background passages. ${ }^{9}$ In the sections on family planning and topics such as gender-based violence, rape and female genital mutilation (Chapters 4 and 5), the family institution is presented primarily as something from which women need protection and that needs to be curtailed or avoided.

Strikingly, it is only at one point in the Action Plan that reconciliation between family and work is made an explicit topic. This occurs in a passage on women's weaker position in business and industry, where the fact that women tend to have 'a greater workload in the family than men' is brought forward as one of several factors explaining gender inequality. ${ }^{10}$ The role of men as fathers, and their opportunities to balance work and family/fatherhood, is absent from the document. This is striking given the importance often assigned to the role of fathers in advancing gender equality for women in the family and in working life. It is also striking because so much weight, nationally, is put on the need for fathers to have an independent relationship with their own children. However, Norway's decision to appeal the case it lost in the ESA judgement, concerning the right of fathers to access the parental-benefit scheme irrespective of the mother's activity, indicates that this concern in the end yields to other, presumably more important concerns - in this case, mothers' employment vs. equal treatment of mothers and fathers.

In line with this almost silencing of issues related to the work-life balance, the Action Plan neither reflects nor addresses solutions to the challenges faced by women - and men - in relation to combining full participation in economic and political life with family life and parenthood, or how to even out women's 'greater workload' in unpaid caring and house work. 
The avoidance of this issue is noteworthy given how the Action Plan gives women's participation in the labour market, in politics and in society in general the highest priority, and how other means of increasing female participation - for example, by ensuring women's equal economic rights and education and supporting women's organizations in civil society - are given substantive treatment (MFA, 2016a: 15-21). Indeed, the complete absence from the Action Plan of a work-life-balance approach and a discussion of the role of family policy of some kind is rather remarkable, particularly given Norway's own experiences in these areas and the fact that parental-leave schemes, family-friendly public services and publicly subsidized kindergartens are highly regarded in terms of their role in facilitating high levels of female employment and women's political participation in national policy-making and public debate. Family policies are not addressed in the foreign minister's launch speech nor in the minister of children and equality's CSW statement, which also emphasize the importance of women's participation and equal opportunities between women and men, and repeatedly mention 'education', 'female entrepreneurship', 'economic rights' and 'access to productive resources' as instrumental for achieving this, while leaving out work-life issues and family policy. In this way, Norway promotes itself as a gender-equality leader and equal-opportunities regime, while making few references to the women- and family-friendly social policies that have arguably been key for these achievements.

\section{Gender mainstreaming}

Gender mainstreaming has been the official strategy of gender-equality policy in Norway for 40 years - that is to say, since the adoption of the Gender Equality Act in 1978. The mission statement of the Act was 'to promote equality and in particular the position of women' (§1a). To fulfil this aim, it was stated that 'all public authorities shall facilitate for gender equality in all areas of responsibility' (§1b). Since the late 1990s, the gender-mainstreaming strategy also corresponded with a stronger prioritizing of gender-equality policy within the EU, including equal-opportunity policies opening for positive action and institutionalization of gender-sensitive norms and practices in public policy more broadly (Hafner-Burton and Pollack, 2002, 2009).

Gender mainstreaming is a challenging approach because it requires that all central actors analyse the gender aspects of any policy process. Gender mainstreaming in Norway presupposes that equality efforts should be integrated into the daily work of all authorities, in all decision-making processes and by all relevant actors. However, reviews of the implementation of mainstreaming activities in national, regional and local public administration have made clear that such activities are scarce (Norges offentlige utredninger, 2011). Although gender mainstreaming is anchored in the activity duty of the Gender Equality Act and in government instructions for policy preparation, where an obligation to conduct gender-sensitive consequence 
analysis has existed since the mid-2000s, there has been no monitoring of such written obligations. No comprehensive gender budgeting is in place; no systematic assessment of consequences for gender equality in legislation and policy formulation has been carried out; equality work has mainly been geared towards temporality in the form of various action plans on different areas; and there has been little equality expertise available to guide equality-eager authorities. In short, there seems to have been a one-eyed focus on gender-equality 'integration', in parallel with a limited understanding of how effective integration needs separate institutions with sufficient resources, capacity and authority to push, plan, guide and monitor.

When we turn to Norway's conceptualization and promotion of gender equality in the international arena, gender mainstreaming appears as a key strategy and connects to the emphasis on the UN's role and UN conventions and structures. Concretely, gender mainstreaming is connected to the Beijing Platform For Action and highlighted in the Action Plan as an approach that 'commits governments to integrate a gender perspective into all policies and programmes' (MFA, 2016a: 9).

The Action Plan is quite specific about how the gender-mainstreaming approach is to be implemented. It highlights, for example, how Norway will seek to ensure that multilateral development banks integrate gender equality as a systematic concern in their core activities and thus report on female job creation and women's economic rights, especially in precarious areas (MFA, 2016a: 20). According to the plan, Norway will 'promote effective implementation of the World Bank's gender-equality strategy', integrate gender equality in work 'to advance private-sector development' ('for example through Norfund's ${ }^{11}$ agreements with the companies it has invested in') and promote inclusion of gender-equality concerns in UN organizations, such as the United Nations Industrial Development Organization (UNIDO) and the Food and Agriculture Organization (FAO) (MFA, 2016a: 20).

At the same time, it is also emphasized that gender mainstreaming is a demanding strategy. Gender mainstreaming entails diverse and complex questions, and coordination and comprehensive work, along with strategic priorities, are necessary to achieve mainstreaming goals. ${ }^{12}$ What is noteworthy from the perspective of Norway's own experiences, however, is, first, how gender mainstreaming as a strategy is not highlighted as something with longer and deeper roots in Nordic gender-equality policy and legislation. Instead, gender mainstreaming is framed largely as a Beijing 1995 innovation and as growing out of UN processes. Second, even if it is made explicit that gender mainstreaming is a 'challenging' strategy, the systematic failures of implementation in Norway, a gender-equality 'superpower', are not mentioned or drawn upon to assist the formulation of lessons learned. Illustratively, the lack of separate responsible resource organizations to oversee and enforce 'integration' - a likely key explanation of Norway's own unimpressive record in this area - is not listed among the obstacles to effective gender mainstreaming. 


\section{Gender balance in decision-making}

Quota policies and preferential-treatment arrangements are a hallmark of Norwegian gender-equality policy. Quotas applying to the nomination procedures of political parties have been sequentially adopted since the late 1970s; in relation to appointments to public boards and commissions since the 1980s and 1990s; and - most famously - for the membership of corporate boards since the early 2000s (for an overview, see Skjeie and Teigen, 2012; Teigen, 2018). Interestingly, the regulation on gender quotas for corporate boards was not included in the Gender Equality Act, but was made part of company law, to ensure stricter enforcement. The sanction system specifies that a company that does not have a board that is in compliance with the legislation will be given several warnings (followed by fines) to allow it to correct the matter. If, despite these measures, it fails to comply with the legislation, it will then be subject to forced dissolution. This case thus constitutes a clear exception to the general trend of weak enforcement mechanisms in Norwegian equality legislation.

Various forms of preferential-treatment policies have long been in place in relation to admissions to higher education and hiring within such institutions, as well as within public administration in general. Yet, in 2003, a case before the EFTA court decided against the University of Oslo's targeted earmarking of specific postdoctoral positions. The earmarking arrangement was found to violate the European Economic Area agreement as it reserved certain positions exclusively for women (Norges offentlige utredninger, 2012: 498), and the further interpretation of this decision by the Norwegian authorities put new limitations on a hitherto favoured preferential-treatment tool of Norwegian gender-equality policy.

Quota policies and preferential treatment have also had varying results in terms of ensuring more gender-balanced decision-making. In Norway, as in the other Nordic countries, a discrepancy exists between the relatively balanced representation of men and women in political decision-making, on the one hand, and high levels of vertical gender segregation in the labour market, especially in the business sector, on the other (Teigen and Wängnerud, 2009; Niskanen, 2011; Teigen et al., 2019).

Women's participation in central societal arenas is also a key point in all the reviewed documents. In accordance with this, the strong underrepresentation of women in political decision-making and governing bodies worldwide is presented as a major challenge to gender equality, both in the two ministers' speeches and in the Action Plan. ${ }^{13}$ In the Action Plan, 'women's political rights and empowerment' is singled out as a key priority and thematic area, and as crucial to ensuring all 'their democratic freedoms and rights' (MFA, 2016a: 15). Norway will thus 'engage in normative efforts' in the international arena to foster gender balance in politics, to support actors who engage in the process of increasing the presence of women in political processes, and to ensure a stronger participation among women in peace 
processes and negotiations (MFA, 2016a: 15-17). In line with this, the minister of children and equality stresses the importance of 'gender-balanced government' in the opening passage of her speech at the CSW, while the foreign minister emphasizes how 'power' is crucial for gender equality 'because we cannot accept that women only constitute $22 \%$ of the parliamentarians of the world because we cannot accept the glass ceiling that continues to exist in many places for women in the private sector. ${ }^{14}$

In other words, there is no question that the Norwegian government speaks very clearly about the need to achieve gender balance in political decision-making. Moreover, in this area, Norway is repeatedly depicted as a pioneer country: 'Just think about how our own society has developed because of women's participation in politics,' states the foreign minister in his Action Plan launch speech, ${ }^{15}$ before going on to emphasize how Norway consistently works for women's political participation in the international arena, during times of war and peace, through the UN and through support for human rights activism and social justice. ${ }^{16} \mathrm{On}$ this point, however, there is more ambivalence in the CSW statement: 'Still, even in our prosperous and gender-equal country,' the minister of children and equality notes, 'men dominate positions of power. We see it in finance, law firms, academia, and in our main rural industries - fisheries and agriculture. Where power and money dominate - men prevail.' Although this is just one instance, this is a reminder of the persistent challenges Norway faces regarding both vertical and horizontal gender segregation in the labour market.

Still, what remain consistently silenced both in the speeches and in the Action Plan are the policies that have been instrumental in Norway's 'prosperity' in this area, and how gender-quota policies specifically have been adopted to promote gender balance in decision-making assemblies, from parliaments to corporate boards. ${ }^{17}$

\section{Silencing and voicing patterns revisited}

From our outline above, the gender-equality policy promoted internationally by Norway deviates quite substantially from the priorities of the country's domestic gender-equality policies. Norway has an advanced equality legislation, subscribes to a gender-mainstreaming strategy, and has high rates of female employment and relatively high levels of women's representation in decision-making bodies. Clearly, some of the aims and instruments promoted in the branding documents overlap paths and approaches in gender-equality policy at home. It also makes sense that the Norwegian government in these documents highlights Norway's efforts abroad to support gender-equality initiatives and the judicial and policy frameworks of the UN and other international organizations. Norwegian nation-branding also directs attention to the fact that Norway is a high achiever in the gender-equality area when compared to many other countries, and it is only 
to be expected that the government would highlight these credentials for international audiences.

It is harder to understand why some of the features of Norwegian genderequality policy that are widely recognized as fundamental, and that in research and national policy discussions are considered central to the country's high achievements in the gender-equality area (see Skjeie et al., 2019), are left out. As we have learned from the branding literature, successful nation-branding typically promotes recognized successes and comparative advantages. On this basis, we should expect Norway to boast about its policy innovations and well-functioning approaches and instruments in gender-equality policy. Why are advantages such as an equality and anti-discrimination legislation that emphasizes proactive duties, worklife balance policies set up to enable the combination of equal parenthood and equal labour-market participation, and the contribution made by the introduction of electoral quota policies to women's presence in political decision-making not put forth as major achievements that other countries could learn from? It would appear that some of the characteristics of Norwegian gender equality that would seem the most brandable have been left conspicuously unbranded.

Existing scholarship on gender equality in Nordic-style national branding suggests that branding patterns may reflect a toning down of radical feminist questioning of gender and sexuality norms that are unpopular and controversial among some home audiences. On this point, there may be some non-trivial inter-Nordic differences. To our knowledge, all the Nordic countries brand themselves as gender-equality promoters to the international community. However, whereas Sweden, for example, explicitly brands its foreign policy as 'feminist', Norway has been reluctant to use that term (Skjelsbæk and Tryggestad, 2019). The difference between Norway and Sweden accords with a general finding of differences between the Norwegian and Swedish gender-equality discourses. The differences between the two are harder to detect, however, when it comes to actual policies and gender relations (Teigen and Wängnerud, 2009; Teigen and Skjeie, 2017; Goul Andersen and Shamshiri-Petersen, 2020). Further, gender-equality policies in the Nordic region - family and quota policies and equality legislation - are well-known among national audiences, have the characteristics of 'social democracy' (Holst, 2018) and are not particularly controversial at home. National policies to promote improvements in gender equality receive relatively high support across voter segments (Hellevik and Hellevik, 2012; Midtbøen and Teigen, 2019). Thus, it is hard to see why there would be a need to downplay them and some of their well-known merits to placate domestic audiences and avoid controversy.

Existing studies of gender equality in Norwegian nation-branding also point at relationships between branding patterns and distinctive historical legacies - for example, how Norway over the centuries has been highlighted as a forerunner when it comes to women's participation in political 
and economic life (Larsen, 2017). Still, it is not clear why this legacy would rule out straightforward talk about the policy and legislative prerequisites of participatory credentials.

For attempts to understand this omission, we believe postcolonial interventions in feminist theorizing (Zuckerwise, 2014; see also Martinsson et al., 2016) can be helpful. One prominent strand of postcolonial feminist critique has argued that Western feminism and gender-equality ideology has prioritized Western problems above gender and other injustices and developmental challenges in other regions and cultural contexts. However, also an almost opposite pitfall has been highlighted in the claim that Western gender-equality proponents have failed or hesitate to recognize that problem definitions and struggles for gender equality in both non-Western and Western contexts may have shared features. In these instances, the underlying conception of the world seems to be that the 'non-Western' situation is, for one thing, somehow and overall shared, and, second, fundamentally different from the more advanced situation in the West. This worldview is then combined with a linear narrative in which 'they' are positioned at a 'less developed' stage, not yet ready to be introduced to 'our' more developed problems and policy exchanges. These assumptions are all obviously problematic given the great variation in cultural, social and policy contexts in both Western and non-Western parts of the world that result in similarities and differences across countries and regions that do not fit easily into any simple linear, dichotomous scheme. However, it is a perspective that may assist us in illuminating the more puzzling aspects of the branding patterns we have identified. Seemingly, it could make sense to leave out even the most recognized of policy successes, such as the merits of Nordic-style family policy. This may even be the case on occasions where a central rationale is to make 'our nation' shine, if the fundamental contentions are that these successes are not remotely relevant to 'them', since their situation and policy challenges are of an essentially different and 'early-stage' kind.

\section{Conclusion}

In this chapter, we have investigated how the branding abroad of four main areas of Norwegian gender-equality policy corresponds with - or deviates from - our knowledge of policy qualities and effects recognized in research and national policy discourse. With some exceptions, we found that Norwegian national experiences regarding policy failures, as well as instances where Norway has been at the receiving end of international policy diffusion, are largely put aside. This is not surprising in the light of scholarship on national branding that sees 'good' branding as emphasizing successes while downplaying negative effects. The almost systematic downplaying of Norwegian policy achievements in the gender-equality area - from family policies to quota arrangements - is harder to make sense of. Inspired by postcolonial feminist theory, we suggest that a certain linear narrative that 
distinguishes between 'our' advanced policies and policy problems, on the one hand, and 'their' less-advanced challenges, on the other, can help us illuminate this key aspect of the identified branding patterns.

There are some limits to our study and analysis. For one thing, our approach would benefit from an analysis of more branding documents and an expansion of the range of methods used - to include, for example, interviews with relevant governmental staff - which would enable us to check the extent and strength of the patterns identified here. Comparative studies between the Nordic countries would also be useful.

Still, despite these limitations, we believe the descriptive conclusions that we have presented from our research so far deserve attention and follow-up studies. They also raise new research questions. There may, for example, be feedback loops between how policies are presented and branded to the outside world and national policy conceptions (Marklund, 2017).

Competing accounts of the patterns identified in the present study must also be considered more closely. First, it could be argued that in this chapter we have placed too high demands on political speeches and generally framed action plans of the kind we have been analysing. We find that the documents we have studied address the policy and regulatory levels of gender-equality politics only in very limited ways, and maybe this is no less than we should expect in the type of discourse we have scrutinized. Yet, even if the documents we have reviewed have a sketchy approach to policy, they touch upon a range of substantive policy references and priorities. It is difficult to see how also including references to Norwegian family policy or some of the more detailed characteristics of the national equality legislation would somehow be discursively 'impossible'.

Second, differences between policy areas and between the focus of specific ministries - for example, between the Ministry of Foreign Affairs and the Ministry of Children and Equality - may play a role. Yet, our broader reading so far suggests that the inter-ministerial differences on this point are limited. ${ }^{18}$ It is also possible that the political colour of the government matters. Conservative governments, for example, may tend to emphasize female entrepreneurship and girls' equal access to education more than quota and family policies. Still, foreign affairs is among the policy fields least characterized by party-political cleavages.

Importantly, it could be argued that some of the branding patterns that have puzzled us reflect how criticism from postcolonial feminism and similar corners has actually been taken on board by Norwegian policy-makers and is reflected in their branding strategies. We should not ethnocentrically assume that policies that work in the Nordic region - be these parental-leave schemes or gender quotas in corporate boards - are realistic, workable options in other parts of the world. Hence, maybe the omissions we find, for example, in the Action Plan are quite sensible given the social and cultural situations and policy contexts that are addressed therein. 
Yet it is not obvious that the policies that are listed in plans and emphasized in speeches are easier to implement and would work better outside the Nordic region (the strategy of gender mainstreaming, mentioned repeatedly in the Action Plan, is known to have failed in most contexts so far). Considering the recent wide spread of electoral quotas all over the globe (Dahlerup, 2006; Krook, 2008) and the international diffusion of work-life balance norms, also in UN contexts, we should also be careful to think of measures such as quotas and parental-leave schemes as 'utopic' proposals once we leave the Nordic context.

\section{Notes}

1 This choice of themes obviously leaves out other core areas, such as violence against women, gender perspectives on health and equal-pay policies. Still, we argue that the four areas on which we focus have been particularly central to official gender-equality policy and allegedly Nordic innovations (Skjeie et al., 2019).

2 A low threshold implies that it is easy and free to make a complaint about discrimination.

3 The system of enforcement of the equality low threshold means that it is easy to make a complaint; however, the system is only able to decide upon whether discrimination has occurred and lacks sanction mechanisms.

4 UN Sustainable Development Goal 5 is to 'achieve gender equality and empower all women and girls'.

5 'Når det kommer til likestilling, er Norge en supermakt.' 'Norge er en global leder. Vi er i front for jenters rett til utdanning.'

6 'Frihet fordi alle mennesker skal bestemme over eget liv. Likestilling gir frihet til både kvinner og menn.... Muligheter fordi alle jenter og kvinner skal kunne bruke sine evner. Alle jenter og kvinner skal kunne gi sine fullverdige bidrag til samfunnet. Vi kan ikke tolerere at religion, kultur eller tradisjon brukes for å diskriminere jenter og kvinner. Dette er kjernen av problemet. Dette må motarbeides uansett hvor det skjer. Menneskerettighetene er universelle. De gjelder for alle. Overalt. I FNs bærekraftsmål nummer 5 forplikter vi oss til å oppnå likestilling for jenter og kvinner.'

7 For example, when it is stated that 'Norway will promote the development of non-discriminatory legislation through the UN's normative processes and support at country level, [and] compliance with, and implementation of, legislation relating to women's rights' (MFA, 2016a: 17).

8 The argument was that the Norwegian parental-leave benefit is not an employment or working condition in the context of the equal-treatment directive. Hence, the activity requirement for the mother is not in violation of the directive. For the EFTA decision, see EFTA Court (2019).

9 For example, in the general introduction to the Action Plan:

The fundamental aim of Norway's gender equality-efforts is to increase the opportunities available to women and girls, promote their right to selfdetermination and further their empowerment.... Norway will help to ensure that women gain a stronger position in the family, in the community and in the international arena.

(MFA, 2016a: 5) 
10 'Women encounter various obstacles that prevent them from participating in business activities and in the labour market in general, and are overrepresented among those working under unacceptable conditions. There are political, economic, legal, cultural and other structural obstacles to women's participation in the labour market. Women in fragile situations are at particular risk of discrimination and exclusion. Women have less control over the world's resources than men. They also have a greater work load in the family than men, both in developed and in developing countries. This means that they compete in the labour market on less advantageous terms than men. In many countries, disparities in economic, political and legal rights, and social and cultural obstacles, are the greatest barriers to women starting up, running and further developing their own businesses. Examples include women's lack of property rights and restrictions on women's access to bank accounts. This means that the transition from the informal to the formal sector is often time-consuming' (MFA, 2016a: 18).

11 Norfund is an investment company owned by the Ministry of Foreign Affairs.

12 'Experience shows that mainstreaming the gender perspective is challenging. The approach to this work has not been strategic enough. In addition to the priority areas set out in the Action Plan, the Ministry will identify specific areas for active mainstreaming of gender equality and women's empowerment. In other areas, we will carry out risk assessments of projects to ensure that they do not have any negative consequences for gender equality and women's empowerment. These steps are necessary in order to concentrate our efforts and ensure that they produce results' (MFA, 2016a: 31).

13 However, 'a slight increase in the number of women members of parliament' is recognized: 'The figure today is $23 \%$ compared with $12 \%$ in 1995 .'

14 'Makt fordi vi ikke kan akseptere at kvinner kun utgjør 22 prosent av verdens parlamentarikere, fordi vi ikke kan akseptere at glasstaket fortsatt er intakt mange steder for kvinner i privat sektor.'

15 'Det andre området i planen er kvinners politiske deltakelse. Det å ha en stemme til å påvirke beslutninger er essensielt. Tenk bare på hvordan vårt eget norske samfunn har utviklet seg på grunn av kvinners deltakelse i politikken.'

16 'Norge arbeider for kvinners politiske deltakelse, i situasjoner med krig og konflikt, så vel som i fred og utvikling... Vi vil fortsette å ta dette opp i FN. Vi vil fortsette å støtte menneskerettighetsforsvarere som står i fremste linje i kampen mot urett.'

17 Gender quotas have also gained a prominent position internationally as a way of regulating gender balance in political decision-making and corporate boards (Hughes et al., 2017; Piscopo and Clark Muntean, 2018; see also International IDEA, n.d.), and are an important factor in the increase in women's presence in politics in many countries. Interestingly, the latter is highlighted in the Action Plan, but not connected to the significance of quota measures.

18 Consider, for example, Minister of Children and Equality Solveig Horne's speech at the She Decides conference in Brussels, 2017, where the persistent challenges of gender segregation in Norway were left unmentioned.

\section{References}

Borchorst A and Siim B (2016) Woman-friendly policies and state-feminism: Theorizing Scandinavian gender equality. Feminist Theory 9(2): 207-224. doi:10.1177/1464700108090411.

Borchorst A, Freidenvall L, Kantola J, Reisel L and Teigen M (2012) Institutionalizing intersectionality in the Nordic countries? Anti-discrimination and equality in 
Denmark, Finland, Norway and Sweden. In: Krizsan A, Skjeie H and Squires J (eds) Institutionalizing Intersectionality? The Changing Nature of European Equality Regimes. Basingstoke: Palgrave Macmillan, 59-88.

Dahlerup D (ed.) (2006) Women, Quotas and Politics. London: Routledge.

Danielsen H, Larsen E and Owesen IW (2015) Norsk likestilling 1814-2013. Bergen: Fagbokforlaget.

EFTA Court (2019) Dom i sak E-1/18 EFTAs overvåkningsorgan v Norge. Domstolen avviser ESAs anmodning om norske foreldrepenger. Pressemelding 04/2019. 13 December. Available at: https://eftacourt.int/wp-content/uploads/2019/12/1_18_ PR_NO.pdf (accessed 17 August 2020).

Ellingsæter A-L (2014) Nordic earner-carer models: Why stability and instability? Journal of Social Policy 43(3): 555-574.

EUR-Lex (2015) Judgment of the Court (Fourth Chamber) in Case C-222/14, Konstantinos Maïstrellis v Ypourgos Dikaiosynis, Diafaneias kai Anthropinon Dikaiomaton, 16 July 2015; available at: https://eur-lex.europa.eu/legal-content/ EN/TXT/?uri=CELEX\%3A62014CJ0222 (accessed 17 August 2020).

Fan Y (2005) Branding the nation: What is being branded?' Journal of Vacation Marketing 12(1): 5-14.

Fetscherin M (2009) The determinants and measurement of a country brand: The country brand strength index. International Marketing Review 27(2): 466-479.

Goul Andersen J and Shamshiri-Petersen D (2020) Danskerne utgør Skandinaviens bagtrop. Holdninger til ligestilling blandt befolkningerne i Danmark, Sverige og Norge. In: Dahlerup D and Borchorst A (eds) Konflikt og konsensus. Det danske ligestillingspolitisk regime. Fredriksberg: Frydenlund Academics, 221-252.

Hafner-Burton EM and Pollack MA (2002) Mainstreaming gender in global governance. European Journal of International Relations 8(3): 339-373.

Hafner-Burton EM and Pollack MA (2009) Mainstreaming gender in the European Union: Getting the incentives right. Comparative European Politics 7(1): 114-138.

Hellevik T and Hellevik O (2012) Holdninger til likestilling. In: Hansen T and Slagsvold B (eds) Likestilling Hjemme. NOVA-rapport 8/2012. Oslo: NOVA Norsk institutt for forskning om oppvekst, velferd og aldring, 117-159. Available at: https://www.researchgate.net/publication/264713176_Likestilling_hjemme (accessed 17 August 2020).

Hellum A (2021) Not so exceptional after all? Nordic gender equality and controversies linked to the Convention on the Elimination of All Forms of Discrimination against Women. In: Larsen E, Moss SM and Skjelsbæk I (eds) Gender Equality and Nation-Branding in the Nordic Region. Abingdon: Routledge, 173-190.

Hellum A and Blaker Strand V (2017) Solberg-regjeringens forslag til reformer på diskrimineringsfeltet. Kritisk Juss 43(1): 4-34.

Holst C (2002) Statsfeminismens moralske grammatikk. In: Holst C (ed.) Kjønnsrettferdighet. Utfordringer for feministisk politikk. Oslo: Gyldendal Akademisk, 54-88.

Holst C (2018) Scandinavian feminism and gender partnership. In: Witoszek, N and Midttun A (eds) Sustainable Modernity. The Nordic Model and Beyond. London: Routledge, 102-118.

Holst C (2020) Fra Helga Hernes til \#metoo. Tidsskrift for kjønnsforskning 44(1): 68-73. doi:10.18261/issn.1891-1781-2020-01-06.

Hughes MM, Paxton P and Krook ML (2017) Gender quotas for legislatures and corporate boards. Annual Review of Sociology 43: 331-352. doi: 10.1146/ annurev-soc-060116-053324. 
International IDEA (n.d.) Gender quotas database. Available at: https://www.idea. int/data-tools/data/gender-quotas (accessed 30 December 2020).

Jezierska K and Towns A (2018) Taming feminism? The place of gender equality in the 'Progressive Sweden' brand. Place Branding and Public Diplomacy 14: 55-63.

Ketscher K (2019) Uden titel. Diskriminering? Nej tak! In: Holst C, Skjeie H and Teigen M (eds) Europeisering av nordisk likestillingspolitikk. Oslo: Gyldendal Akademisk, 78-105.

Krizsan A, Skjeie H and Squires J (eds) (2012) Institutionalizing Intersectionality. The Changing Nature of European Gender Equality Regimes. London: Palgrave Macmillan.

Krook ML (2008) Quota laws for women in politics: Implications for female practice. Social Politics 15(3): 345-368.

Larsen E (2017) 'A brand-new nation state': Women's suffrage as international branding. Paper presented at the Nordic Branding Kick-Off Conference, University of Oslo, 12-13 June.

Leira A (2002) Working Parents and the Welfare State: Family Change and Policy Reform in Scandinavia. Cambridge: Cambridge University Press.

Leira A (2012) Omsorgens institusjoner, omsorgens kjønn. In: Ellingsæter AL and Widerberg K (eds) Velferdsstatens familier. Nye sosiologiske perspektiver. Oslo: Gyldendal Akademisk, 76-93.

Lister R (2009) A Nordic Nirvana? Gender, citizenship, and social justice in the Nordic welfare states. Social Politics 16(2): 242-278.

Marklund C (2017) The Nordic model on the Nordic market of ideas: The welfare state as Scandinavia's best brand. Geopolitics 22(3): 623-639.

Martinsson L, Griffin G and Giritili Nygren K (2016) Challenging the Myth of Gender Equality in Sweden. Bristol: Bristol University Press.

Midtbøen AH and Teigen M (2019) Verdipolarisering i norsk kontekst? Avstand mellom elite og befolkning i holdninger til innvandring og likestilling. Politica 51(1): 61-81.

Moss S (2017) Nordic branding of gender: Social representation, identities and political usage in diplomacy. Paper presented at the Nordic Branding Kick-Off Conference, University of Oslo, 12-13 June.

Niskanen K (2011) Gender and Power in the Nordic Countries: With Focus on Politics and Business. Oslo: NIKK Publications.

Norges offentlige utredninger (2011) Struktur for likestilling. NOU 2011: 18. Oslo: Departementenes servicesenter, Informasjonsforvaltningen.

Norges offentlige utredninger (2012) Politikk for likestilling. NOU 2012: 15. Oslo: Departementenes servicesenter, Informasjonsforvaltningen.

Norwegian Ministry of Children and Equality (2018) CSW: National StatementNorway by Former Minister Linda Hofstad Helleland. Oslo: Norwegian Ministry of Children and Equality. Available at: https://www.regjeringen.no/no/aktuelt/ csw-national-statement---norway/id2593814/ (accessed 10 August 2020).

Norwegian Ministry of Foreign Affairs (MFA) (2016a) Freedom, Empowerment and Opportunities: Action Plan for Women's Rights and Gender Equality in Foreign and Development Policy 2016-2020. Oslo: Norwegian Ministry of Foreign Affairs. Available at: https://www.regjeringen.no/globalassets/departementene/ud/ vedlegg/fn/womens_rights.pdf (accessed 10 August 2020).

Norwegian Ministry of Foreign Affairs (MFA) (2016b) Innlegg under lanseringen av Frihet, makt og muligheter, 2 September 2016. Oslo: Norwegian Ministry of 
Foreign Affairs. Available at: https://www.regjeringen.no/no/aktuelt/innlegg_ handlingsplan/id2510275/ (accessed 10 August 2020).

Piscopo JM and Clark Muntean S (2018) Corporate quotas and symbolic politics in advanced democracies. Journal of Women, Politics and Policy 39(3): 285-389. doi: 10.1080/1554477X.2018.1477396.

Reisel L (2019) Stabilitet og endring $i$ det kjønnsdelte arbeidsmarkedet. Oslo: Institute for Social Research. Available at: https://samfunnsforskning.brage.unit.no/ samfunnsforskning-xmlui/handle/11250/2632471 (accessed 11 July 2020).

Skevik A and Hatland A (2003) Family policies in Norway. In: Ostner I and Schmitt $\mathrm{C}$ (eds) Family Policies in the Context of Family Change: The Nordic Countries in Comparative Perspective. Wiesbaden: Verlag für sicialwissenscaft. Available at: https://www.researchgate.net/publication/239570482_Family_Policies_in_Norway (accessed 11 July 2020).

Skjeie H and Teigen M (2012) Duties to promote equality. In: Freidenvall L and Micheletti M (eds) Comparisons, Quotas and Critical Change. Stockholm: Stockholm University, 55-61.

Skjeie H, Holst C and Teigen M (2017) Benevolent contestations: Mainstreaming, judicialization and Europeanization in the Norwegian gender+ equality debate. In: MacRae H and Weiner E (eds) Towards Gendering Institutionalism. London: Rowman \& Littlefield International, 121-141.

Skjeie H, Holst C and Teigen M (2019) Splendid isolation? On how a non-member is affected by - and affects - EU gender equality policy. In: Dustin M, Ferreira $\mathrm{N}$ and Millns S (eds) Gender and Queer Perspectives on Brexit. Cham: Palgrave Macmillan, 439-461.

Skjelsbæk I and Tryggestad TL (2018) Norway's peace engagement: What gender has to do with it? Paper presented at the Nordic Branding Annual Meeting, Copenhagen, 12-13 June 2017.

Skjelsbæk I and Tryggestad TL (2019) Likestilling og Norges fredsengasjement - en balansekunst. Tidsskrift for kjønnsforskning 43(4): 306-320.

Syse KL (2017) Nordic masculinity: Exploring and devouring Nordic nature. Paper presented at the Nordic Branding Kick-Off Conference, University of Oslo, 12-13 June.

Teigen M (2018) The 'natural' prolongation of the Norwegian gender equality policy institution. In: Lépinard E and Rubio-Marin R (eds) Transforming Gender Citizenship: The Irresistible Rise of Gender Quotas in Europe. Cambridge: Cambridge University Press, 341-365.

Teigen M and Wängnerud L (2009) Tracing gender equality cultures: Elite perceptions of gender equality in Norway and Sweden. Politics \& Gender 5(1): 21-44.

Teigen, M and Skjeie, H (2017) The Nordic Gender Equality Model. In: Knutsen, $\mathrm{O}$ (ed.) The Nordic Models in Political Science. Challenged but still viable? Oslo: Fagbokforlaget, 125-147.

Teigen, Mari, Skjeie, Hege, and Karlsen, Rune (2019) Framing and feedback: increased support for gender quotas among elites. European Journal of Politics and Gender, 2 (3): 399-418, doi: 10.1332/251510819X15639713867651.

Towns AE (2002) Paradoxes of (in)equality: Something is rotten in the gender equal state of Sweden. Cooperation and Conflict 37(2): 157-179.

Towns AE (2017) Branding Sweden through a feminist foreign policy. Paper presented at the Nordic Branding Kick-Off Conference. University of Oslo, 12-13 June. 


\section{Cathrine Holst and Mari Teigen}

Tryggestad TL (2014) State feminism going global: Norway on the United Nation's Peacebuilding Commission. Cooperation and Conflict 49(4): 464-482.

Vollset G (2011) Familiepolitikkens historie - fra 1970 til 2000. NOVA-rapport 1/2011. Oslo: NOVA - Norsk institutt for forskning om oppvekst, velferd og aldring. Available at: https://fagarkivet-hioa.archive.knowledgearc.net/bitstream/handle/ 20.500.12199/3362/4479_1.pdf?sequence=1\&isAllowed=y (accessed 10 August 2020).

Walby S (2004) The European Union and gender equality: Emergent varieties of gender regimes. Social Politics 11(1): 4-29.

Walby S (2009) Globalization and Inequalities: Complexity and Contested Modernities. London: Sage.

Zuckerwise LK (2014) Postcolonial feminism. The Encyclopedia of Political Thought. Wiley Online Library. Available at: https://onlinelibrary.wiley.com/doi/ abs/10.1002/9781118474396.wbept0812 (accessed 10 August 2020). 


\title{
9 Not so exceptional after all?
}

\author{
Nordic gender equality and \\ controversies linked to the \\ Convention on the Elimination \\ of All Forms of Discrimination \\ Against Women
}

Anne Hellum

In the 1970s, the Nordic countries were among the first in the world to pass general laws that prohibited gender discrimination and sought to promote gender equality. They also played an active role in the drafting of UN gender policies and the Convention on the Elimination of All Forms of Discrimination Against Women (CEDAW), which was enacted by the UN General Assembly in 1979. These legal achievements feature in the Nordic success story regarding gender equality in fields like politics, work, education and family life, both at home and abroad (see more about this development in Chapter 8 of this volume by Holst and Teigen). They are also central elements in the image of a Nordic gender-equality model, which is associated with strong state feminism ${ }^{1}$ accompanied by laws and policies that promote substantive equality in all areas. Gender-equality and anti-discrimination legal frameworks could thus have been part of a strong women-friendly regional brand.

It is therefore puzzling that, in many respects, the Nordic countries' equality and anti-discrimination laws and policies are lagging behind the dynamic developments that are taking place in international equality and anti-discrimination law, particularly CEDAW and European Union law (Nielsen, 2012; Hellum, 2013; Nousiainen and Pentikäinen, 2013; Svensson and Gunnarsson, 2018). The Nordic states' argument that legislation that would have the effect of making CEDAW and other conventions apply directly in national law would skew the balance between the judiciary and the parliament and as such undermine representative democracy has been termed the Nordic human rights paradox (Føllesdal and Wind, 2009; Skjeie, 2009; Langford and Schaffer, 2013; Bailliet, 2016). This argument can be seen as a breach with being international heavyweights on gender equality.

Since the 1980s, and through the increased internationalization and Europeanization of equality and anti-discrimination laws and policies, the image of Nordic gender-equality exceptionalism has been increasingly challenged. In a context where 189 states have ratified CEDAW, gender equality has become a legal principle to which most states ascribe. Yet, whereas they were 
among the first to initiate and ratify CEDAW, the Nordic countries have in later years resisted the CEDAW Committee's call for legislation that ensures that the Convention applies directly in national law and takes precedence when coming into conflict with national law. This chapter will describe this development by outlining how different images and legal representations of gender equality have travelled back and forth between the Nordic countries and the UN from the 1970s to the present, and what this might entail for branding the countries and region as champions of gender equality.

The empirical starting point is an examination of the CEDAW Committee's responses to the periodic state reports of Nordic countries. The overall focus is on contestations regarding the relationship between CEDAW and these Nordic countries' gender-equality and anti-discrimination laws. An in-depth study of how Norway has responded to critical comments from the CEDAW Committee is supplemented with an analysis of responses from Sweden, Denmark and Finland. The chapter shows how the homecoming of international equality and anti-discrimination standards that these countries support at the international level is often met with resistance at the national level. There is a mismatch between the image as gender-equal champions at home and the international critique of national law. A comparison between these Nordic countries' responses to the CEDAW Committee's critique shows that, unlike the other countries, Norway has to some extent changed its equality and anti-discrimination laws to bring them into line with the Committee's recommendations. An examination of public debates in Norway regarding the status of CEDAW in Norwegian law suggests that Norway's reputation as an international champion of women's rights and human rights is a factor that influences law and policy-making. Bringing the country's actions in line with the brand as a superpower on gender equality is seen as a factor that may have influenced this motivation.

\section{The trajectory of anti-discrimination law in the Nordic countries}

The Nordic countries' enactment of general gender-equality and antidiscrimination laws in the 1970s and 1980s signalled the start of a strategic shift from specific and programme-based to general and rights-based gender-equality strategies. ${ }^{2}$ Until that time, gender equality had been promoted through a combination of piecemeal abolition of laws and policies that constituted formal discrimination against women and political measures. A characteristic feature of the Nordic countries' approach to equality was the use of corporative agreements and programmes that involved the state, labour unions and women's organizations.

While all of the Nordic countries have had gender-equality and antidiscrimination laws in place since the 1980s, the histories, legal and political origins, designs and enforcement systems of their various legal frameworks 
vary. Combining both gender-neutralized and gender-specific elements, the 1978 Norwegian Gender Equality Act set out to promote gender equality and improve the position of women. In 2017, it was replaced by a single law, the Equality and Anti-Discrimination Act, that covered discrimination on grounds that included gender, sexual orientation, gender identity, pregnancy, care, ethnicity, disability and combinations of these factors so-called intersectional discrimination. The new act, which also combines both gender-neutralized and gender-specific elements, sets out to improve the position of women, minorities and people with disabilities. The Swedish Sex Equality Act of 1980 was replaced in 2009 by a single law, the Discrimination Act, that covered seven grounds of discrimination, but not combinations of these grounds.

Unlike Norway and Sweden, Finland and Denmark have maintained separate gender-equality acts. Finland's 1986 Act on Equality between Women and Men was a direct result of the country's ratification of CEDAW. A gender-neutralized act, however, was seen as the most appropriate means of promoting gender equality. In Denmark, the 1975 Act on Equal Pay and the 1978 Act on Equal Treatment in the Labour Market were the first acts that prohibited gender discrimination. In 2006, these two acts were merged into a single Act on Equal Treatment in the Labour Market. This was in 2009 replaced by the Equal Rights Act, which also applies in areas outside the labour market. Neither the Finnish nor the Danish acts provide protection against intersectional discrimination.

Through their inputs to the preamble to the Convention on the Elimination of All Forms of Discrimination Against Women, the Nordic countries promoted the ideal of a family model where men and women worked outside the home and shared responsibilities for care and housework at home. Indeed, Sweden prompted the inclusion of the 14th paragraph of the preamble, according to which the states parties to the Convention declare that they are 'aware that a change in the traditional role of men as well as the role of women in society and in the family is needed to achieve full equality between men and women' (Rehof, 1993: 40). This formulation was influenced by Swedish sociologist, politician and diplomat Alva Myrdahl and her efforts to work for both Swedish and international reforms where individual liberty (especially for women) went hand in hand with shared responsibility for children both between the parents as well as between the family and the community. Denmark, Finland and Norway followed Sweden and shared the aim of emphasizing the importance of 'the role of both parents in the family and the upbringing of children' embedded in the 14th paragraph of the preamble. Sweden stated that 'true equality between men and women could not be introduced by means of measures dealing exclusively with women: some measures aiming to bring about changes in the traditional role of men would be required' (Rehof, 1993: 56). The Nordic countries thus supplemented the gender-specific prohibition against discrimination 
'against women' in Article 1 of CEDAW with a gender-neutralized and symmetric conception of equality.

\section{Critiquing the champions}

Since ratifying CEDAW, the Nordic countries have regularly submitted periodic state reports to the CEDAW Committee that monitors states' compliance with the Convention (Byrnes, 2012; Hellum and Ikdah1, 2019). These reports describe the progress of their efforts to respect, promote and fulfil the rights of women to substantive equality and protection against all forms of discrimination. The CEDAW Committee reviews these reports and issues concluding observations, which form an assessment of the states' performance.

In its concluding observations on the reports from the four Nordic countries, the CEDAW Committee has expressed similar types of critiques regarding the shortcomings of the gender equality and anti-discrimination laws of each country. Below, we will take a closer look at three sets of criticisms that have set off controversies about the role of CEDAW in Nordic law. These controversies provide a window into changing external and internal gender images and the representation of gender equality as a hallmark of the Nordic states in general, and of Norway in particular.

The first set of contestations derive from the CEDAW Committee's requirement that states parties to the Convention facilitate the independent participation of women's rights organizations in the state reporting procedure. While the Nordic countries, through the provision of development aid, have provided economic support to enable women's rights organizations in the global South to participate in the state reporting procedure, such support was not given to Nordic women's organizations. This practice shows how CEDAW was initially viewed by the Nordic states as a tool to promote women's rights in the global South and not in the Nordic countries.

The second controversy derives from the CEDAW Committee's call for constitutional and statutory measures to ensure that the Convention takes precedence over national laws that come into conflict with the principle of gender equality expressed in the Convention. National resistance to this requirement epitomizes tensions between the Nordic image of gender equality as an overall national value and political and legal traditions based on strong state prerogatives and popular majoritarian democracy.

The third controversy illustrates the tense relationship between, on the one hand, the CEDAW Committee's call for gender-specific and intersectional equality and anti-discrimination laws and, on the other, the Nordic countries' strong emphasis on gender-neutralized and one-dimensional equality and anti-discrimination laws, as well as policies that are premised on the sociocultural notion of sameness. 


\section{The first controversy: why does civil society's ability to hold states accountable matter more in the South than in the North?}

The CEDAW Committee, like other human rights treaty bodies, requires that the states parties to the Convention facilitate the independent participation of national human rights institutions and civil society in the state reporting procedure. The CEDAW Committee has paid particular attention to the states parties' duty to include women's rights organizations. The aim of this requirement is to promote state accountability through a balanced procedure whereby civil society - particularly women's organizations from all parts of the world - has access to international law. Initially, as a part of their international gender policies, the Nordic states provided economic support to women's rights organizations in what were termed third world countries so that they could participate in the CEDAW Committee's scrutiny of their states' reports. In the Nordic countries, with their imagined gender equality, such support was not provided. This was due partly to the fact that CEDAW was viewed by Nordic policy-makers as a tool for women's development in the third world and partly to the state-feminist approach to equality, with its blurred boundaries between state and civil society.

Since the 1980s, CEDAW has constituted the backbone of the Nordic countries' rights-based international gender policies. While Denmark has been criticized by the CEDAW Committee for its lack of attention to CEDAW's role in development policies. Norway, Finland and Sweden have been commended for their promotion of women's human rights in their development cooperation activities. ${ }^{3}$ Initially, the Nordic countries saw lack of state transparency and accountability as a phenomenon that stood in the way of gender equality in third world countries. Supporting the competence of women in the third world to write independent shadow reports and participate in the state reporting process was thus a central part of Finland, Sweden and Norway's international gender-equality policies. An example is the 2007 Action Plan for Women's Rights and Gender Equality in Development Cooperation (Ministry of Foreign Affairs, Norway, 2007). Like the earlier Strategy for Women and Gender and Equality in Development Cooperation (Ministry of Foreign Affairs, Norway, 1997), it was anchored in CEDAW. In the Foreword to the Action Plan, Minister of Development Erik Solheim stated that

The Government wants Norway to be a fearless champion of women's rights and gender equality. Accordingly, the rights, participation and influence of women will be at the core of Norway's development cooperation efforts. Our aim is to ensure the realization of the rights of women that are set out in international human rights conventions.

(Ministry of Foreign Affairs, Norway, 2007: 7) 
The Action Plan saw human rights and democracy as mutually constitutive. It stated that Norway would use the CEDAW Committee's concluding observations on Norway's partner countries in development cooperation as the point of departure for dialogue and priority-setting. Civil society, particularly women's organizations, was identified as a key actor in development and democracy-building. By providing economic support to enhance the competence and capacity of women's organizations to write independent shadow reports and participate in CEDAW's state reporting procedure, the Action Plan set out to promote democracy in terms of accountability vis-à-vis national authorities.

The state reporting procedures in the Nordic countries were for a long time a different ball game. Initially, women's organizations were not given an opportunity to present independent reports but were consulted as part of the preparation of the state report. This state-feminist approach, characterized by a blurring of the boundaries between state and civil society, did not sit well with the CEDAW Committee's call for independent NGO participation. It also differed from the approach favoured within the international gender policy of the Nordic countries where independent NGO reporting was actively promoted.

The Norwegian case study shows how democratic flaws in the statefeminist policy were challenged by the CEDAW Committee, which insisted that Norwegian women's rights organizations be given economic support to write independent shadow reports and participate in the proceedings (Hellum, 2013: 604). ${ }^{4}$ An in-depth study of the participation of Norwegian women's organizations in the CEDAW reporting process between 1982 and 2008 reveals that that the participation of nongovernmental women's organizations in these processes was severely limited (Halsaa and Thun, 2010). The study also shows that, for the most part, comments from the women's organizations were not included as separate attachments to the state's CEDAW report but were incorporated within the report without any specific reference being made to the statements made by the actual organizations. ${ }^{5}$ In 2007, Norwegian women's organizations wrote their first shadow report to the CEDAW committee without state funding. ${ }^{6}$ Owing to this lack of funding, however, the women's organizations were unable to present their shadow report in the Committee's preparatory meeting in New York. The Norwegian shadow report was thus presented to the Committee by the Malaysian representative of the international network International Women's Rights Action Watch (IWRAW). In its concluding comments on Norway's seventh periodic report, the CEDAW Committee took notice of 'the absence of Norwegian NGOs at the session, apparently for lack of funding. ${ }^{7}$ In 2011, for the first time, 32 women's organizations coordinated by the NGO FOKUS received funding from the Ministry of Family and Equality to produce and present an NGO shadow report to the CEDAW Committee. In its concluding comments on Norway's eighth periodic report, the Committee commended 'the State party for its financial 
support of women's organizations (NGOs) for the finalization of a shadow report and for travelling expenses to both the pre-session working group and the session'. ${ }^{8}$

The Norwegian case reveals the disjuncture between the country's national and international gender policies. It suggests that the Norwegian state's self-image as a pioneer of gender equality stood in the way of critical scrutiny of democratic flaws in the existing state-feminist policy according to which women's organizations were regarded as an integrated part of a corporate political culture. Rather than seeing Norway as exceptional in the light of its high score on global gender indexes, the CEDAW Committee insisted that Norway follow the same standards for Norwegian women's organizations as it did for third world women in relation to the right to independent access to international law. The fact that the CEDAW Committee saw the state-feminist approach as depriving Norwegian women's organizations of the right to independent democratic participation drew the attention of international women's rights organizations such as the IWRAW. Such negative international attention was a factor that motivated Norway to change its practice in order to reassert its reputation as a promoter of gender equality at home and abroad.

\section{The second controversy: why do the Nordic states resist incorporation of CEDAW into national law?}

Through their ratification of CEDAW and other human rights instruments, all of the Nordic states have agreed to implement international standards of gender equality and non-discrimination in national law. Human rights principles such as the rights to equality, self-determination, integrity and dignity are values that are shared by different political parties, different civil society organizations, different branches of government and different schools of jurisprudence in the Nordic region. It is therefore a puzzle that most of the Nordic countries have resisted the CEDAW Committee's call to incorporate CEDAW into their domestic legal systems to make it directly applicable in national law. The reluctance of Sweden, Denmark and Norway to make CEDAW directly applicable in national law speaks to the ambiguous and contested relationship between gender equality and national identity in those countries. The Norwegian controversy over incorporation, however, shows how women's rights organizations and independent human rights institutions can use CEDAW's state reporting procedure as a means of accountability in ways that may result in change.

Article 2 of CEDAW requires all state parties to incorporate the Convention into their domestic legal systems to secure the enforceability of its provisions at the national level. In General Recommendation 28, the Committee urges 'those States parties in which the Convention does not form part of the domestic legal order to consider incorporation of the Convention to render it part of domestic law, for example through a general law on 
equality, in order to facilitate the full realization of Convention rights as required by article 2 '.

In its reviews of state reports from Sweden, Denmark and Norway, the Committee has repeatedly concluded that these countries have failed to ensure that the Convention prevails over national law. Finland's Constitution, which, unlike the constitutions of the other Nordic countries, states that binding human rights conventions apply directly in national law, is unproblematic. ${ }^{9}$ In its concluding comments on Sweden's seventh periodic report, which was followed up by a combined eighth and ninth report, the CEDAW Committee expressed concern that

the provisions of the Convention, even though largely respected, have not yet been fully incorporated into the domestic legal system of the State party and, as a result, are not directly applicable in the national courts. $^{10}$

In its concluding comments on Denmark's reports, the CEDAW Committee has repeatedly called for legal measures that ensure the full incorporation of CEDAW within national law. ${ }^{11}$ In its concluding comments on the country's eighth periodic report, the Committee expressed regret that

notwithstanding its previous recommendation (CEDAW/C/DEN/CO/7, para. 15), the State party decided in October 2014 not to incorporate the Convention into its national legal order. In that regard, the Committee is concerned that the State party's Supreme Court has ruled that nonincorporated treaties do not have the same status in national law as incorporated treaties. ${ }^{12}$

In its consideration of Norway's fifth and sixth periodic reports in $2003,{ }^{13}$ the CEDAW Committee expressed concern that CEDAW had not been incorporated into Norway's Human Rights Act and recommended that the act be revised to incorporate CEDAW. This recommendation, which was not followed up by the Norwegian state, was reiterated by the Committee in its concluding comments on Norway's eighth periodic report. ${ }^{14}$

The Nordic countries have responded in different ways to the CEDAW Committee's call for incorporation. Denmark's wholesale rejection is notable, while Sweden has expressed a political will during dialogue to address the remaining gaps in its incorporation of CEDAW's provisions within national law. ${ }^{15}$ Unlike these countries, after ten years of resistance, Norway decided to follow the CEDAW Committee's call for incorporation of CEDAW into national law. On 19 June 2009, almost 30 years after Norway's ratification of CEDAW, the Women's Convention and the Optional Protocol to the Convention were incorporated into Norway's Human Rights Act. According to Article 2 of that act, in cases of conflict between the Human Rights Act and other provisions of Norwegian law, the former takes precedence. 
In order to understand the process whereby incorporation of CEDAW was promoted, resisted and finally adopted by the Norwegian state, I will take a closer look at the different legal narratives that were invoked by various state and non-state actors at different stages of the debate over the issue, which lasted for ten years. These legal narratives highlight the different imaginaries about the relationships between gender, national law and international law that underlie national legal cultures and subcultures. The concept of a national legal culture refers to ideals that are shared by different state and nonstate actors. A broadly agreed notion is that human rights principles such as equality, freedom, dignity and integrity are cornerstones of national law. The concept of national legal subcultures refers to different understandings among legal scholars or branches of state administration of how international law should be interpreted and applied at the national level.

The first integration controversy was about national hierarches of laws. It began with the enactment of the Human Rights Act in 1999, according to which three international conventions would take precedence in the event of conflict between those conventions and other provisions of Norwegian law. These were the European Convention on Human Rights, the International Covenant on Civil and Political Rights, and the International Covenant on Economic, Social and Cultural Rights. ${ }^{16}$ The decision of the social-democratic Stoltenberg I government to exclude CEDAW, the Convention on the Rights of the Child and the International Convention on the Elimination of All Forms of Racial Discrimination from the Human Rights Act gave rise to a fierce debate. This debate was centred around two strands of arguments that constituted different legal subcultures within the national legal culture. State institutions like the Ministry of Justice and the state legal counsel argued that only the 'main' conventions were suitable for incorporation. CEDAW and other 'specialist' conventions were deemed unsuitable. They referred to the Human Rights Law Commission, which had introduced a distinction between 'main conventions' and 'special conventions' in 1993 (Norges offentlige utredninger, 1993). In this way, they invented a national human rights hierarchy within which, owing to their 'specialist' character, CEDAW, the Convention on the Rights of the Child and the International Convention on the Elimination of All Forms of Racial Discrimination were ranked lower than the 'main conventions'.

This position was criticized by state and non-state actors who argued that all human rights were equal and that, by excluding CEDAW, the $\mathrm{Hu}-$ man Rights Act established a gendered human rights hierarchy that was in conflict with Norway's international reputation as a promoter of women's rights at home and abroad. When the Human Rights Act was passed in 1999, a majority in the Norwegian parliament requested that the Stoltenberg I government incorporate CEDAW and the Convention on the Rights of the Child into Norwegian law 'within reasonable time'. ${ }^{17}$ Most state institutions and independent national human rights institutions such as the Ministry of Education, the Ministry of Children and Family, the Ministry of Foreign 
Affairs and the Gender Equality Ombud shared the view that, since women's rights and gender equality were core principles both in international and in Norwegian law, CEDAW should be incorporated. In spite of this, the Christian Democratic coalition government (Bondevik I) that replaced the Stoltenberg I government lent its ear to the Ministry of Justice and the state legal counsel. These actors were of the view that incorporation of CEDAW and other conventions in the Human Rights Act would undermine Norway's existing legal culture, which was founded on values such as clarity and predictability. The use of metaphors that associated CEDAW with specificity, inferiority, chaos and indecisiveness, as opposed to the clear and general character of the main conventions, speaks to the gendered character of the dominant national legal culture that on the surface appeared gender-neutral.

The second aspect of the integration controversy turned on notions of democracy. In 2003, in its review of Norway's fifth and sixth periodic reports, the CEDAW Committee noted that CEDAW had not been incorporated into the Human Rights Act and recommended that

the State party amend section 2 of the Human Rights Act (1999) to include the Convention and its Optional Protocol, which will ensure that the provisions of the Convention prevail over any conflicting statutes and that its provisions can be invoked in domestic courts. ${ }^{18}$

The same year, a new argument in the controversy was introduced in the report of the Power and Democracy Commission (Norges offentlige utredninger, 2003). The overall concern of the majority in the Commission was that the growing number of international treaties ratified by the Norwegian state curtailed parliamentary democracy. The minority in the Commission, however, argued that international human rights instruments like CEDAW constituted a tool for a fairer distribution of power and resources between women and men and, as such, a means of achieving greater democracy (Skjeie, 2003).

The arguments and concerns articulated by the majority in the Commission became a powerful tool in the hands of the Ministry of Justice and the state legal counsel. They argued that incorporation of CEDAW into the $\mathrm{Hu}-$ man Rights Act would skew the balance between the judiciary and the parliament and accordingly undermine representative democracy. On the basis of advice from these state actors, the Christian Democratic coalition government (Bondevik II) concluded that the rule of precedence, embedded in the Human Rights Act, should in future be restricted to very special cases in relation to incorporation of international conventions:

In the light of certain international bodies' dynamic interpretation of international law - going in directions beyond the scope of what the legislative branch of government at the time of incorporation reasonably 
could foresee - there is ample reason to emphasize the need to be as consistent as possible in relation to the incorporation of international treaties that have a binding effect. The government is of the view that rules giving international law precedence in the event of conflict with other Norwegian law should be used restrictively. ${ }^{19}$

The law and democracy argument breathed new life into the national hierarchy argument that had been rejected by the Norwegian parliament in 1999. Faced with a threat to national popular democracy, the Bondevik II government concluded that it was of the utmost importance to uphold the legal boundary between international and national law. The Ministry of Children and Equality therefore proposed that CEDAW should be incorporated into the Gender Equality Act and not be given precedence in the event of conflict with other provisions of Norwegian law. ${ }^{20}$ This proposal was met with criticism from actors like the Gender Equality Ombud, the Ministry of Foreign Affairs, the Norwegian Centre for Human Rights, the Institute of Women's Law and women's organizations. These actors were of the view that incorporation of CEDAW into the Human Rights Act would strengthen the position of women in law and society, and accordingly strengthen democracy. The Bondevik II government's proposal was approved by a Conservative majority in the Norwegian parliament in 2005, but was opposed by Labour, the Socialist Left Party and the Centre Party.

The third integration controversy was about national status. Could the resistance of the Norwegian state to putting CEDAW on an equal footing with other conventions affect its legitimacy as an internationally acclaimed women's rights champion? This question was invoked by non-state actors that included women's rights organizations and experts in the fields of women's, gender and equal rights studies who were in favour of incorporation.

A key concern in this debate was how the state's resistance to incorporation of CEDAW undermined Norway's efforts to be 'a fearless champion of women's rights and gender equality', as the 2007 Action Plan for Women's Rights and Gender Equality in Development Cooperation put it (Ministry of Foreign Affairs, Norway, 2007: 7). The legitimacy argument was directed at the announcement by the centre-left coalition government (Stoltenberg II) that, to protect national democracy, it needed to reconsider its political promise to incorporate CEDAW into the Human Rights Act. ${ }^{21}$ The government was publicly asked how its changed position would affect its legitimacy as a 'champion of human rights'. The disjuncture between CEDAW's low status in national law and the way in which Norway 'branded' itself as a champion of women's human rights on the international scene was thus brought to the public's attention, in part through a debate between the author and the Minister of Justice. ${ }^{22}$ In spring 2009, the Ministry of Justice and the government legal counsel were publicly criticized for their political resistance and lack of loyalty to the policy of the Stoltenberg II government regarding the incorporation of CEDAW in national law (see Andenæs, 2008; 
Hellum, 2008; Hellum et al., 2009). As a result, the government changed its position, and the Ministry of Justice sent out a White Paper recommending incorporation of CEDAW into the Human Rights Act, which was approved by the parliament. ${ }^{23}$ In his address to the Norwegian parliament, while affirming the centrality of the principle of gender equality as a national value, the minister of justice emphasized that this was the very last convention that would ever be incorporated into the Human Rights Act. ${ }^{24}$

These three aspects of the controversy over CEDAW's incorporation into national law speak to the tense relationship between the Norwegian state's identity as an international champion of women's human rights and the perception of international law as a threat to an 'imagined community' of original Nordic ethnicity. They show how a strong protection of women's human rights can coexist with a weaker protection of other groups, such as people with disabilities or ethnic minorities. A puzzle in this regard is how the internationalization of women's rights and gender equality, on the one hand, blurs the boundaries between Nordic and international law and, on the other, evokes nationalist feelings according to which CEDAW and other human rights conventions are perceived as an external threat to the imagined community of ethnic Nordic gender equality (Kantola and Nousiainen, 2009). This tension between changing laws and sociocultural perceptions suggests that the notion of gender equality in the Nordic countries in practice is premised on the notion that sameness between women and men and between majority and minority groups is necessary if different groups are to get along (Gullestad, 2001; Hellum, 2011).

\section{The third controversy: why are the Nordic countries resisting the CEDAW Committee's call for gender-specific anti- discrimination laws?}

Another contested issue is whether equality and anti-discrimination laws in the Nordic countries should be moulded on a gender-neutralized or a gender-specific legal design. A related issue is whether gender as a ground for discrimination should be constructed on the basis of a single identity or include protection against discrimination that is a result of interplay between gender and other grounds, such as ethnicity, sexual orientation, disability or age - so-called intersectional discrimination. CEDAW is a gender-specific convention that, according to Article 1, prohibits 'all forms of discrimination against women'. The CEDAW Committee, in its review of state reports, emphasizes that a gender-specific legal guarantee is necessary for combating the asymmetrical character of gender relations (Byrnes, 2012; Hellum and Ikdahl, 2019). Recognizing that discrimination of women on the basis of sex and gender is inextricably linked with other factors that affect women, such as race, ethnicity, religion or belief, health, status, age, class, caste, sexual orientation and gender identity, the CEDAW Committee also calls for legal protection against intersectional discrimination. In the following, I will explore tensions and conflicts between the Committee's call 
for gender-specific legislation that provides protection against intersectional discrimination and existing images and legal representation of gender in the Nordic countries.

The gender-neutralized design of most Nordic gender-equality and antidiscrimination legislation is premised on the view that gender equality is a matter of changing the roles of both women and men. To showcase this position, the Nordic states have over the last 15 years systematically selected male candidates to serve on the CEDAW Committee, the majority of whose members are female gender experts. As a result, the candidature of more competent female candidates has not been considered (Bailliet, 2016).

There are, however, tensions between this seemingly gender-neutralized and symmetric position and the CEDAW Committee's emphasis on the need to strengthen the position of women in order to achieve substantive equality.

In its review of the Nordic state reports, the Committee has emphasized the need for legislation that recognizes the skewed distribution of power and resources between women and men. Such concerns were expressed in the Committee's concluding comments on Denmark's eighth ${ }^{25}$ and Finland's fifth and sixth periodic reports. ${ }^{26}$ In its comments on Sweden's combined eighth and ninth periodic reports, the Committee clearly stated that it did not agree with Sweden's view that a gender-neutralized and single discrimination act was the best way of addressing gender discrimination. The Committee recommended that

the State party should also evaluate and, if necessary, revise the scope of protection of its Discrimination Act in order to ensure that it contains a definition of discrimination against women in accordance with article 1 of the Convention, covering inter alia, intersecting forms of discrimination. ${ }^{27}$

Another recurrent critique from the CEDAW Committee is that the onedimensional conception of gender discrimination that is prevalent in the Nordic gender-equality and anti-discrimination legislation is unsuited to addressing the discrimination challenges posed by increasing sociocultural diversity and transnationalism. ${ }^{28}$ In its consideration of Finland's sixth periodic report, the Committee stated that

the Gender Equality Act and the Non-Discrimination Act do not currently provide adequate protection to women against multiple or intersecting forms of discrimination. ${ }^{29}$

In line with this, the Committee urged the Finnish state to

ensure that reforms explicitly affording protection to women against multiple or intersecting forms of discrimination in all national gender equality and anti-discrimination laws are adopted in a harmonised manner. ${ }^{30}$ 
Unlike Sweden, Finland and Denmark, Norway has to some extent taken into consideration the CEDAW Committee's recommendations regarding the need for a gender-specific act that provides protection against intersectional discrimination. Norway's 2017 Equality and Anti-Discrimination Act replaces the Gender Equality Act of 2013. It is a single act that merges four specific anti-discrimination laws into one general equality and antidiscrimination act. The reform process, which was subject to several interventions by the CEDAW Committee, sparked off a series of controversies regarding the construction of gender equality and gender discrimination. The outcome of the process was an act whose aim was in line with CEDAW's call for a gender-specific legal guarantee. According to Article 1 of the 2017 Equality and Anti-Discrimination Act: 'This Act has the particular objective of improving the position of women and minorities.' Furthermore, Article 6 of the act provides protection against intersectional discrimination. The prohibition against discrimination in Article 6 includes discrimination on the basis of 'gender, pregnancy, leave in connection with childbirth or adoption, care responsibilities, ethnicity, religion, belief, disability, sexual orientation, gender identity, gender expression, age or combinations of these factors'.

CEDAW's state reporting procedure clearly fed into longstanding internal contestations regarding gender-specific, gender-neutralized and intersectional legal representations of gender in Norwegian equality and anti-discrimination law. The women's rights movement and the Equality Ombud have made systematic use of CEDAW's state reporting procedure as an arena in which to make different governments accountable for the proposed weakening of women's right to equality and non-discrimination. In the NGO shadow report commenting on Norway's eighth periodic report to the CEDAW Committee, women's organizations argued that the abolition of the Gender Equality Act would be

contrary to the obligation under the CEDAW, which requires dynamic action. Another consequence would be that differential treatment aimed at improving the status of women would be put on par with differential treatment aimed at improving the status of men. ${ }^{31}$

In her Supplementary Report to the Committee, the Equality Ombud commented:

If protection against discrimination on grounds of gender is incorporated in a new comprehensive Act without retaining the 'statement of purpose', the Ombud sees a danger that the work against discrimination of women can be weakened. A neutral statement of purpose in a comprehensive Act will obscure the fact that, as a society, Norway has not achieved full gender equality, and that discrimination has a gender perspective that still requires targeted efforts and measures aimed at improving the position of women in particular. ${ }^{32}$ 
In its concluding comments on Norway's eighth periodic report, the Committee noted the proposed abolition of the Gender Equality Act that set out to promote the position of women and expressed concern about

the use of gender-neutral legislation, policies and programs, which might lead to inadequate protection of women against direct and indirect discrimination and hinder the achievement of substantive equality of women and men. ${ }^{33}$

Against this background, and after a long public debate, the Conservative coalition government (Solberg II) decided to propose a single equality and anti-discrimination act with the specific purpose of improving the position of women, minorities and people with disabilities. It also decided to formalize existing practices in which the Equality Ombud, the Equality Tribunal and the lower courts provided protection against discrimination on a combination of grounds.

All in all, this picture of how the Nordic countries have resisted or adopted the CEDAW Committee's recommendations shows the contested terrain in which different gender images and legal definitions of gender equality travel back and forth between local, national and international legal arenas, and may be influenced by the imaging the countries in question wish to engage in of their own position on gender equality. Norway's adoption of a combined gender-neutralized and gender-specific act that provides protection against intersectional discrimination shows how national legal struggles may be influenced by the desire to maintain an international reputation as a promoter of women's human rights and gender equality. It should be borne in mind that, when the single equality act was passed in 2017, Norway's Prime Minister Erna Solberg was co-chairing with President Nana Addo Dankwa Akufo-Addo of Ghana the UN Secretary General's advocacy group for global goals - the Millennium Development Goals, followed by the Sustainable Development Goals.

\section{A Nordic equality model with five exceptions?}

An examination of the CEDAW Committee's reviews of Nordic state reports has shown that Nordic gender-equality legislation and practices in many instances fall short of international standards. Accordingly, the CEDAW Committee's concluding comments on the periodic reports of the Nordic states constitute a counter-narrative to the global gender indexes that through statistical ranking reproduce the external idea of the Nordic countries as havens of gender equality. An examination of the CEDAW Committee's concluding observations also reveals the disjuncture between the way in which the Nordic countries 'brand' themselves on the international scene and the different ways and degrees to which they resist full integration of international standards in their national laws. Accordingly, the CEDAW 
Committee's critical observations call the picture of the exceptional nature of the Nordic gender-equality model into question.

The diversity of approaches to national equality and anti-discrimination laws within the Nordic countries and their different responses to criticism from the CEDAW Committee also begs the question whether Nordic gender-equality laws, like the Nordic welfare model, should be seen as 'a model with five exceptions' (Christiansen et al., 2006). One puzzle in this context is why the CEDAW Committee, in spite of the strong resistance put up by powerful Norwegian state actors, has had greater impact on Norwegian legislation than in Sweden, Denmark and Finland. The outcome of the Norwegian CEDAW controversies, described in this article, suggests that international reputation and status are factors that under certain circumstances may influence national laws and policies concerning women's rights and gender equality.

\section{Notes}

1 The term 'state feminism' refers to cooperation between the women's movement and state authorities. The idea of the women-friendly Scandinavian welfare states was introduced by Norwegian political scientist Helga Hernes (1987).

2 For an overview of these developments in the Nordic countries, see Nordic Information on Gender (n.d.).

3 See CEDAW Concluding Comments on Denmark's fourth and fifth periodic reports, A/57/38, para. 321; CEDAW/C/FIN/CO/6, para. 165; CEDAW/C/SWE/ $\mathrm{CO} / 8-9$, para. 4.

4 In Sweden, the first independent NGO report was written in 2001 by two Swedish UN organizations on behalf of the country's women's organizations. The first state-supported NGO report was written by the Swedish Women's Lobby. In Finland, the first NGO report was written in 2004 and the second in 2008 (Nousiainen and Pentikäinen, 2013).

5 Norway's fifth periodic report, where comments from the Gender Equality Ombud, the Centre for Gender Equality, the MiRA Resource Centre for Black, Immigrant and Refugee Women, and the Women's Front were attached as an appendix, made an exception.

6 The report was a cooperation between FOKUS, Kompetanse- og ressurssenter i internasjonale kvinnespørsmål (Competence and Resource Centre for International Women's Issues), Kvinnesaksforeningen (the Norwegian Association for Women's Rights), Kvinnefronten (the Women's Front) and Internasjonal kvinneliga for fred og frihet (Women's International League for Peace and Freedom).

7 CEDAW/C/NOR/CO/7, para. 5.

$8 \mathrm{CEDAW} / \mathrm{C} / \mathrm{NOR} / \mathrm{CO} / 8$, para. 3.

9 Under Finland's Constitution, binding human rights conventions take direct effect in national law (Nousiainen and Pentikäinen, 2013).

$10 \mathrm{CEDAW/C/SWE} / \mathrm{CO} / 8-9$, para. 14.

$11 \mathrm{CEDAW} / \mathrm{C} / \mathrm{DEN} / \mathrm{CO} / 7$, para. 15

12 CEDAW/C/DNK/CO/8, para. 11.

13 CEDAW/C/NOR/5 and CEDAW/C/NOR/6, para. 21.

$14 \mathrm{CEDAW} / \mathrm{C} / \mathrm{NOR} / \mathrm{CO} / 7$, para. 14.

15 CEDAW/C/SWE/CO/8-9, para. 4.

16 Proposition to the Odelsting No. 3 (1998-1999).

17 Recommendation No. 51 (1998-1999) to the Odelsting, para 1. 
18 CEDAW/C/NOR/5 and CEDAW/C/NOR/6, para. 21.

19 Report No. 17 (2004-2005) to the Storting, 74-75.

20 Proposition to the Odelsting, No. 35 (2004-2005) 80.

21 This political promise was embedded in the socialist coalition government's political statement for the governing period of 2005-2009, the so-called Soria Moria Declaration of 2005.

22 See the debate between in the Norwegian daily newspaper Dagbladet between Anne Hellum (2007) and Minister of Justice Knut Storberget (2007).

23 Høyring - inkorporering av kvinnediskrimineringskonvensjonen i menneskerettsloven, Ministry of Justice, 7 November 2008.

24 Innst. O. nr. (Recommendation to the Odelsting) 115 (2008-2009).

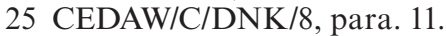

26 CEDAW/C/FIN/CO/6, para. 167.

27 CEDAW/C/SWE/CO/8-9, para. 15.

$28 \mathrm{CEDAW/C/SWE/CO/8,} \mathrm{para.} \mathrm{15;} \mathrm{CEDAW/C/DNK/8,} \mathrm{para.} 12$.

$29 \mathrm{CEDAW} / \mathrm{C} / \mathrm{FIN} / \mathrm{CO} / 7$, para. 10.

$30 \mathrm{CEDAW} / \mathrm{C} / \mathrm{FIN} / \mathrm{CO} / 7$, para. 11.

31 NGO Shadow Report to CEDAW 2011, Supplementing and Commenting on Norway's Eighth Periodic Report on the Implementation of CEDAW at 10.

32 The Equality and Anti-Discrimination Ombud's Report to the Pre-session of the CEDAW. A Supplementary Report on Norway's Eighth Official Report to the CEDAW Committee, p. 7.

33 CEDAW/C/NOR/C08, para. 8.

\section{References}

Andenæs M (2008) Interview with Mads Andenæs, Director of the Norwegian Centre for Human Rights. Klassekampen, 8 June.

Bailliet C (2016) A Nordic approach to promoting women's rights within international law: Internal v. external perspectives. Nordic Journal of International Law 85(4): 368-394.

Byrnes A (2012) CEDAW Article 1. In: Freeman M, Chinkin C and Rudolf B (eds) CEDAW Commentary. Oxford: Oxford University Press, 51-70.

Christiansen NF, Petersen K, Edling N and Haave P (eds) (2006) The Nordic Model of Welfare: A Historical Reappraisal. Copenhagen: Museum Tusculanum Press.

Føllesdal A and Wind M (2009) Nordic reluctance towards judicial review under siege. Nordic Journal of Human Rights 27(2): 131-142.

Gullestad M (2001) Imagined sameness: Shifting notions of us and them in Norway. In: Ytrehus LA (ed.) Forestillinger om 'den andre': Images of Otherness. Oslo: Norwegian Academic Press, 32-57.

Halsaa B and Thun C (2010) Partnering with the state? The role of women's organizations in governmental, CEDAW and CERD consultation processes. FEMCIT Working Paper No. 4. Oslo: Centre for Gender Research University of Oslo.

Hellum A (2007) Politisk spydspiss med sviktende legitimitet. Dagbladet, 8 March.

Hellum A (2008) Konvensjonell sexisme. Dagbladet, 12 June.

Hellum A (2011) The global equality standard meets Norwegian sameness. In: Hellum A, Ali SS and Griffiths A (eds) From Transnational Relations to Transnational Laws. Farnham: Ashgate, 71-93.

Hellum A (2013) Making space and giving voice: The CEDAW in Norwegian law. In: Hellum A and Aasen HS (eds) Women's Human Rights: CEDAW in International, Regional and National Law. Cambridge: Cambridge University Press, 588-625. 
Hellum A and Ikdahl I (2019). Committee on the Elimination of Discrimination Against Women (CEDAW). Max Planck Encyclopedia of International Procedural Law.

Hellum A, Skjeie H and Hernes H (2009) Om å holde ord. Dagbladet, 28 May.

Hernes H (1987) Welfare State and Woman Power: Essays in State Feminism. London: Norwegian University Press.

Holst C and Teigen M (2021) Silenced at the border: Norwegian gender-equality policies in national branding. In: Larsen E, Moss SM and Skjelsbæk I (eds) Gender Equality and Nation-Branding in the Nordic Region. Abington: Routledge, 153-172.

Kantola $\mathbf{J}$ and Nousiainen K (2009) Institutionalising intersectionality in Europe: Legal and political analyses. International Feminist Journal of Politics 11(4): 459-477.

Langford M and Schaffer JK (2013) The Nordic human rights paradox: Moving beyond exceptionalism. University of Oslo Faculty of Law Research Paper No. 2013-25. Available at: https://papers.ssrn.com/sol3/papers.cfm?abstract_id= 2275905\#\# (accessed 14 July 2020).

Ministry of Foreign Affairs, Norway (1997) Strategy for Women and Gender and Equality in Development Cooperation (1997-2005). Oslo: Ministry of Foreign Affairs.

Ministry of Foreign Affairs, Norway (2007) Action Plan for Women's Rights and Gender Equality in Development Cooperation 2007-2009. Extended for the Period 2010-2013. Oslo: Ministry of Foreign Affairs.

Nielsen R (2012) The impact of EU law on Scandinavian law in matters of gender equality. In: Nielsen R and Tvarnø CD (eds) Scandinavian Women's Law in the 21st Century. Copenhagen: Djøf Publishing, 63-90.

Nordic Information on Gender (n.d.) The Nordics: The Nordic gender effect at work. Available at: athttps://nikk.no/en/gender-equality-work-in-the-nordiccountries/ (accessed 6 January 2021)

Norges offentlige utredninger (1993) Lovgivning om menneskerettigheter. NOU 1993 : 18. Oslo: Departementenes servicesenter, Informasjonsforvaltningen.

Norges offentlige utredninger (2003) Makt og demokrati. NOU 2003: 19. Oslo: Departementenes servicesenter, Informasjonsforvaltningen.

Nousiainen K and Pentikäinen M (2013) Rise and fall of the CEDAW in Finland: Time to reclaim its impetus. In: Hellum A and Aasen HS (eds) Women's Human Rights: CEDAW in International, Regional and National Law. Cambridge: Cambridge University Press, 557-588.

Rehof LA (1993) Guide to the Travaux Preparatoires of the United Nations Convention on the Elimination of All Forms of Discrimination against Women. Leiden: Martinus Nijhoff.

Skjeie H (2003) Særuttalelse fra Hege Skjeie. In: Norges offentlige utredninger, Makt og demokrati. NOU 2003: 19. Oslo: Departementenes servicesenter, Informasjonsforvaltningen, 74-87.

Skjeie H (2009) Policy views on the incorporation of human rights conventions: CEDAW in Norwegian law. Nordic Journal of Human Rights 27(2): 260-271.

Storberget K (2007) Politisk kritikk med sviktende legitimitet. Dagbladet, 19 March. Svensson E-M and Gunnarsson $\AA$ (2018) Structuralism versus individualism in Swedish gender equality policy and law. NORA - Nordic Journal of Feminist and Gender Research 26(3): 230-237. 


\title{
10 Creating gender exceptionalism The role of global indexes
}

\author{
Tori Loven Kirkebø, Malcolm Langford and \\ Haldor Byrkjeflot
}

The prevailing discourse of Nordic exceptionalism is saturated by references to the region headlining various global indexes and indicators (Kirkebø et al., 2019). In 2015, Norway topped the Human Development Index and the Economist Intelligence Unit's Democracy Index, was second in two rule of law and human rights indexes, and was third in the World Economic Forum's Global Gender Gap Index (Langford and Schaffer, 2015: 26). This index-infused narrative is not surprising. It fits neatly with the rebranding of the Nordic region that occurred from the 1990s onwards. During the Cold War, the Nordics actively constructed an image for themselves as representing a peaceful middle way between the West and the East - 'market[ing] a brand of rational/modern society and international order' (Browning, 2007: 36). Yet, following the fall of the Soviet Union and the decline of a bipolar world order, this imaginary lost traction - and the region was confronted with a new competition-based multilateral order fuelled by economic globalization, multipolar geopolitics, and rising nationalism (Angell and Mordhorst, 2015). In this competitive environment, indexes provided a ready-to-hand measure of policy achievement across multiple fields, with a high ranking communicating 'excellence' and 'exceptionalism'.

The field of gender equality was soon engulfed by this index-based exceptionalism discourse. Gender equality figures prominently in the global narrative on Nordic exceptionalism. It is 'one of the most prominent hallmarks of the Nordic model' (Melby et al., 2009: 4, quoted in Lister, 2009: 248) and 'integral to Scandinavian citizenship' (Ellingsæter and Leira, 2006: 7; and the Nordics 'have distinguished themselves through their active work to promote gender equality' (Nordic Council of Ministers, 2006: 7). The Nordic gender brand is so powerful that any apparent deviation from gender equality in practice - such as Denmark's poor performance in many indices of gender equality (Kirk, 2019) - is framed as an outlier rather than a challenge to the idea of a Nordic model, or simply not mentioned. Likewise, global indexes are mobilized as central evidence and artefacts in the many descriptions of Nordic gender equality success. Gender equality figured prominently in the early wave of global indexes, and the Nordics performed strongly in the first two, which were launched by the United Nations Development Programme (UNDP) in 


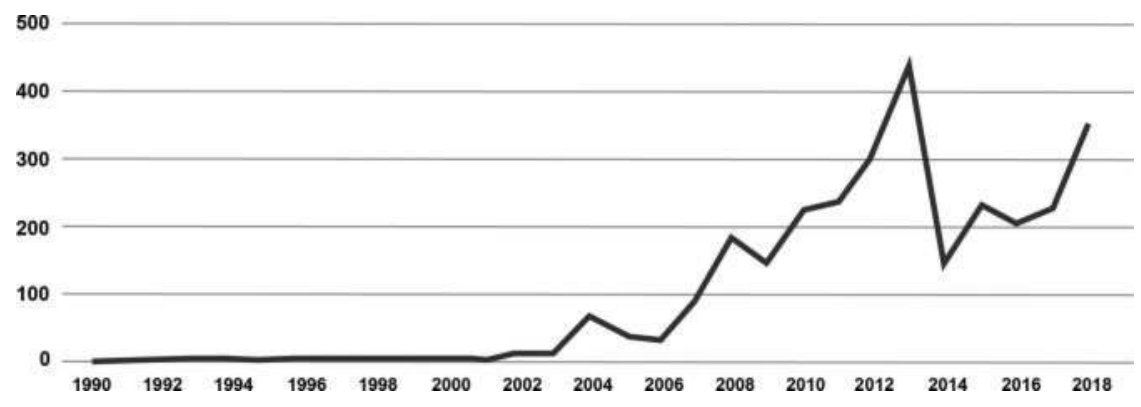

Figure 10.1 Norwegian articles on 'the world's most gender-equal country' over time.

1995: the Gender Development Index and the Gender Inequality Index. The impact of these indexes on the way media reported about gender issues can be witnessed in their distillation into simple slogans or brands (Aspeli, 2018; Bredeveien, 2018). A media analysis in Norwegian newspapers of the phrase 'the world's most gender-equal country' ('verdens mest likestilte') showed a rapid increase in the use of the phrase from 2006 (see Figure 10.1).

In this chapter, we examine critically the rise of global indexes and ask how they helped build and shape the idea of Nordic gender exceptionalism, as the region's members moved from being Cold War-era 'middle way countries' to the 'top of the world' in the age of globalization. In the wake of the index revolution, we find a critical scholarship that raises questions about the material construction of such indices (Apaza, 2009) and a broader social scientific scholarship highlighting their symbolic power in shaping perceptions and policies (Mennicken and Espeland, 2019; Mau, 2020; Davis et al., 2012). As indexes constitute a new form of power, they have naturally attracted sceptical inquiry. Indexes help secure attention and influence, elevate status and moral authority, and, in the process, create new social and symbolic hierarchies, global winners and losers.

We begin the chapter by tracing the rise of global indexes and the literature on their limitations and constructive power, thereafter presenting critically the Nordic rankings across 78 global and 8 gender-specific indexes. This enables us to better understand which features of gender equality are captured by the indicators and what the rankings communicate symbolically. We conclude by analysing the presence of indicators in gender-equality discourse, with a focus on the role of media diffusion. In so doing, we make two principal arguments: (1) that indexes powerfully and peculiarly shape the discourse on Nordic gender exceptionalism and (2) that their constructive limitations and constituent power are often underplayed in policy discussions. 


\section{Ranking the world}

Terms like 'indicator' and 'index' refer to a 'statistic that aims at combining scientific authority with normative authority' (Davies, 2015: 285), a systematic presentation of information that allows for comparison among units over time. Indicators are 'globally circulating knowledge technologies that can be used to quantify, compare and rank virtually any complex field of human affairs' through the creation and defining of social phenomena by naming them and attaching them to data (Davis et al., 2012: 5). Today, they are ubiquitous, ranging from the Sustainable Development Goals to the $\mathrm{Hu}-$ man Development Index (HDI) and the World Bank's Ease of Doing Business Index. Kelley and Simmons (2015) chart a 2,000\% increase in 'global performance indexes' in the period 1994-2014, accompanied by an expansion in themes that move beyond core socio-economic issues.

To be sure, indicators established themselves early in national and international governance (Gates, 1975). However, the creation of global indexes combining a set of indicators in a summary and ranked form - was often the result of one-off experiments by experts in their respective fields without organizational support. This stands in contrast with how index production is integrated today as part of regular and long-term activities of an assemblage of organizations, classified formally as Ranking and Rating Organizations (RROs) (Cooley and Snyder, 2015). These RROs extend beyond international organizations to encompass corporations, civil society organizations and activists, with $75 \%$ of the leading global indexes being produced in the USA (Kelley and Simmons, 2015). Some of these RROs, such as Freedom House, assemble large teams of analysts and expert advisors (up to 125 analysts and 40 advisors in the case of the Freedom in the World Index) (Ringel et al., 2020: 41).

The reasons for this turn to quantification are diverse. Mau (2020) refers to the engines of economization and digitalization as important forces. Economization is represented by the turn towards markets and market mechanisms and the ascendance of evaluation criteria related to efficiency and performance. Digitalization makes the collection, storage and analysis of data substantially more accessible, quicke, and easier. Furthermore, indicators provide a mutually acceptable means of assessment where there is distrust (Rosga and Satterthwaithe, 2009: 280), providing a low-cost means of accountability and control. Advocates and activists can make problems visible; and businesses and governments can monitor and control behaviour. Indexes are also an ideal communications tool. Offering clear, comprehensible and simple snapshots of complex situations, indicators constitute a 'technology of distance' that is 'well suited for communication that goes beyond the boundaries of locality and communication' (Porter, 1995: viii, ix). For news media, indexes helpfully simplify complex issues, provide ready-made narratives (some nations go up, others down), and satiate public interest in issues such as national security and identity. 
Despite playing an important instrumental role, indicators and indexes have two primary limitations, related to their statistical quality (construction) and sociological impact (unintended and intended effects).

First, in relation to statistical quality, it is worth briefly rehearsing the common critiques. Indexes may suffer from a lack of construct validity because they provide a poor or over-simplistic representation of a phenomenon being represented. For example, the global Gender Empowerment Measure measures only the formal (not substantive) participation of women in politics and workplaces. Moreover, indexes may suffer from a lack of reliable and valid data. Recorded observations may not be an accurate reflection of the reality being measured, data may be missing, human bias and error or state interference may have affected data creation, different contexts may affect respondent answers, and the selection of weightings for respondent groups or indicators in an index may be incorrect. Finally, global indexes suffer often from the challenge of excessive aggregation. Seeking to amass many and widely varying countries and issues in a single scale often results in excessive simplification and a lack of differentiation. One common result is data truncation (Barsh, 1993: 102-103; Landman, 2004: 923). High-income countries are bunched at the top of the index, and it is rare to find analysis on whether there are statistically significant differences in the different countries' rankings.

A second set of challenges concern the interpretation and effects of indexes and indicators. What indicators 'actually communicate, and to whom, may not be what their producers and promulgators sought to communicate' (Davis et al., 2012: 11). A common effect is the focus on the measurable. As Davis et al. (2012: 9) remind us, indicators embody a 'theoretical claim about the appropriate standards for evaluating actors' conduct'. If an indicator is loosely matched with a standard or simply achieves prominence, it can quickly take on a normative life of its own. Indicators inevitably become substitutes for the phenomena that they are measuring - 'what gets measured gets managed' - rendering the indicator itself, not what it is measuring, the focus of social action. This includes setting the policy agenda or defining, maintaining and developing a problem field. For example, a consequence of new indexes related to 'good governance' is the introduction of the notion of 'failed' or 'failing' states (Andrews, 2008). Concepts and measurements introduced by RROs gain high salience and will influence how we identify, frame, construct, and respond to global problems.

Another effect of indexes is their mobilization of competitive modes of action and broader use in political economy (Mau, 2020). Global performance indexes are a form of economic and political capital that can be used by various actors for a wide variety of purposes, which may extend beyond the policy problem that initially motivated the creation of a particular index. This secondary use is especially potent in the branding of nations. Rankings help construct a politics of global competition by creating a single political imaginary (Erkkilä and Piironen, 2018) - often through methods such as 
national reputation management and nation-branding. Angell and Mordhorst (2014: 186) explain that national reputation management constitutes a globalization of nationalism in two senses. First, 'it changes the focus of national identity ... to a more external orientation in which the state uses the country's national reputation to promote its interests in the global marketplace'. Second, 'national reputation management moves nationalism out of its traditional political, cultural and ideological field and into the domain of global competition for prosperity - that is, into a commercial field'.

Contemporary indexes facilitate this competition by providing readymade tools for comparison. Indeed, the core of the nation-branding movement is the Nation Brand Index. However, the competition is not confined to pure commercial interests, as indexes have become a new way for states to build political capital and secure political influence (Kelley and Simmons, 2015; Beaumont and Towns, 2018). Indicators create a 'social pressure' by focusing international attention on low-performing nations and organizations, and they provide valuable political capital for states or other actors jostling for political influence (Moss and Langford, 2020).

A final effect is the divergent causal explanations that may be mobilized by the same index or a diversity of indexes. On the one hand, indexes can strengthen or facilitate the circulation of concepts that incorporate the 'core value' in a country's success. A recent and somewhat amusing example is the explosion of interest in and emergence of a global market for the Danish concept of 'hygge' - a common Danish and Norwegian word for a form of comfort. After Denmark was named the happiest country in the world in the 2012, 2013 and 2016 World Happiness Reports, the concept of 'hygge' started to circulate. ${ }^{1}$ Today, there are bestselling books, ${ }^{2}$ webpages ${ }^{3}$ and seminar series ${ }^{4}$ set up in the spirit of - or to sell - 'hygge'. On the other hand, rankings and shifts in them generate, almost instantaneously, a demand for a readily available theory of change. To take the example of the World Happiness Report again, newspaper discussions of why Switzerland was the happiest country in the world in 2015 included the feature of low taxation levels; but, for Denmark in 2016, discussions pointed to the inverse - namely high levels of taxation (Kirkebø et al., 2019). While more serious analyses of the causes of happiness engage with these competing explanations, the conflicting narratives can live on in parallel fashion in the public sphere.

An example of diverse or contradictory explanations can be seen in the field of gender equality. Within the Nordic region, different rankings are mobilized to portray Denmark as either a champion of gender equality or a low performer in comparison with the other Nordic countries. Whereas it is ranked as number 14 in the World Economic Forum's Global Gender Gap Index, which has led to discussions as to why Denmark scores so poorly (Kirk, 2019), other rankings, such as the recent Equal Measures 2030 in which Denmark achieved the top score, made it possible for a campaign to brand Copenhagen as 'the world leader in gender equality'. 5 


\section{Constructing global gender indexes}

To understand the role of rankings in helping shape ideas of Nordic exceptionalism, Byrkjeflot et al. (2018) looked at 78 relevant global indexes. ${ }^{6}$ These were identified in targeted searches and the list assembled by Cooley and Snyder (2015). The indexes were categorized across seven different issue areas: social, economic, infrastructure, governance, global contributions, global perspectives and gender. ${ }^{7}$ The organizations producing the indicators are diverse and were classified as civil society, corporation/interest group, research institute, or international organization. ${ }^{8}$

The average ranking in each category for each Nordic state is shown in Figure 10.2. From a general perspective, there are two notable trends. First, the Nordics perform extremely strong on all indexes, although slightly less so on economic and infrastructure indexes. Second, the performances of Iceland and Finland do not always match those of the other Scandinavian states - which suggests that we might need to think in terms of Scandinavian rather than Nordic exceptionalism.

For present purposes, what is of interest is that Figure 10.2 shows that the highest-ranked category for the Nordics after global contributions (e.g. aid) is gender. This category is composed of eight gender indexes, which are listed in Table 10.1 along with the last-known ranking for each Nordic country. These indexes are: (1) the Gender Empowerment Measure; (2) the Gender Development Index; (3) the Gender Inequality Index; (4) the Gender Equality Index; (5) the Global Gender Gap Index; (6) the Where To Be Born Index; (7) the Mothers Index and (8) the Social Institutions and Gender Index. Not all of these indexes are focused solely on equality (nos 5-6), or are global (nos 7-8) or numerical (no. 8). Nonetheless, the overall pattern is generally clear. In the seven numerical indexes, the Nordics possess an average ranking of 3.6, with the Scandinavian bloc performing most strongly.

When we examine the construction of these eight gender indexes and the reported results more closely, several observations can be made. First, the

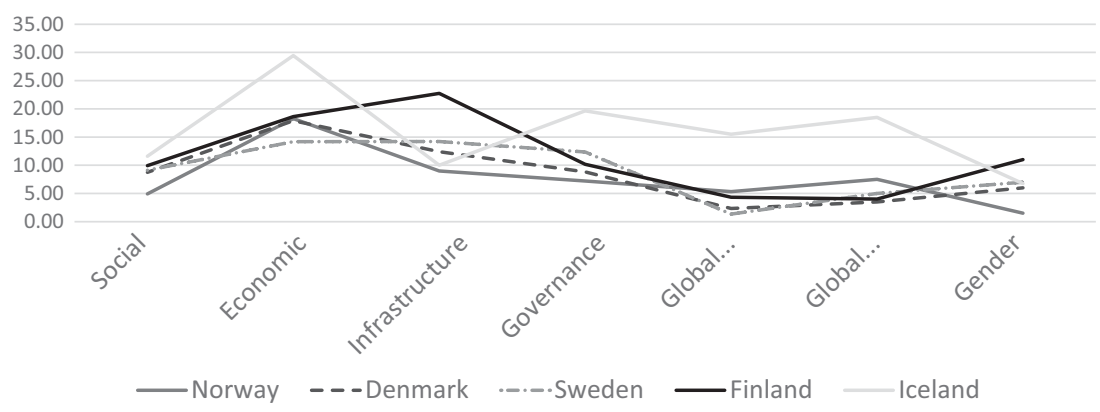

Figure 10.2 Nordic countries' average rank on global indexes. 


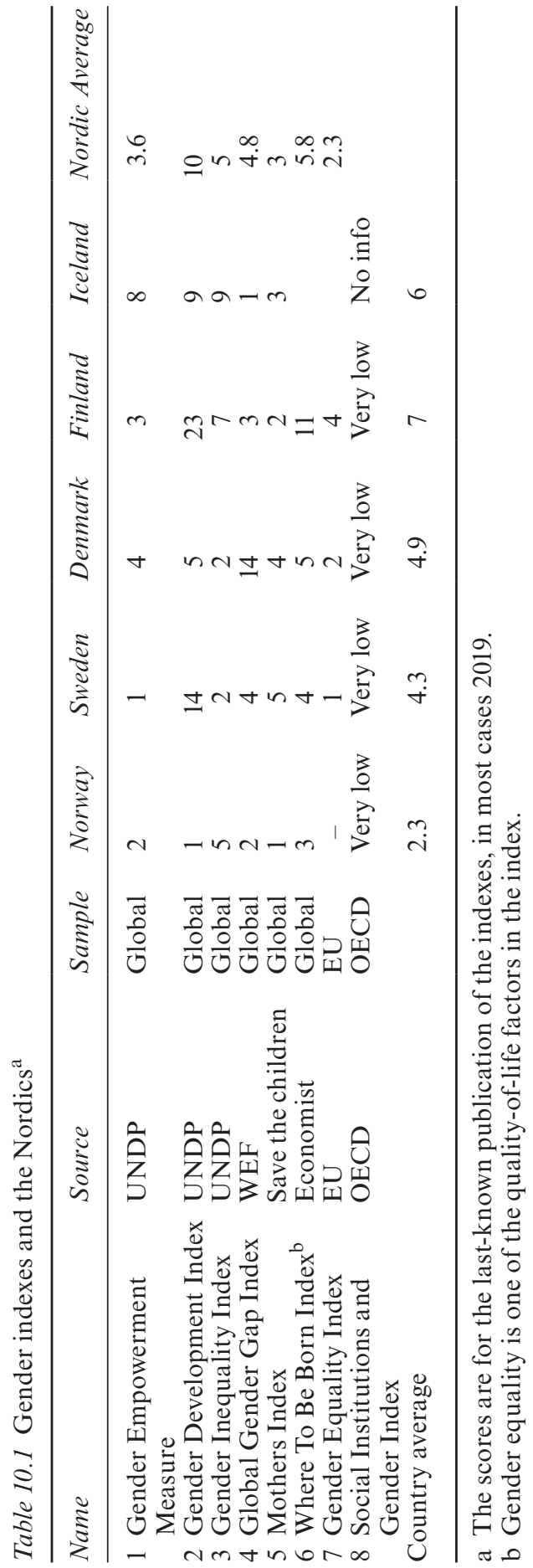


selection and construction of indicators is the subject of critical statistical literature. For example, the UNDP's Gender Development Index (GDI) was first launched in 1995 to adjust the yearly Human Development Index (HDI) scores for the extent to which achievements on income, life expectancy, health and education were shared among men and women.

The GDI faced early criticism though, especially from Bardhan and Klasen (1999), and was subsequently revised. Nonetheless, the same authors later argued that caution should be exercised still in interpreting and applying the revised index in relation to high-performing countries. This is because of concerns with construct validity (choice of constituent indicators) and truncation (small differences between high-income countries in the indicators). 'All this tells us', Bardhan and Klasen continue, 'is that gender bias in the very crude indicators used in the HDI - life expectancy, literacy, gross enrolments, and 'adjusted' income - [is] indeed very small in most rich countries'. Yet, they conclude by noting:

At the same time, this does not mean that more subtle gender inequalities do not exist in rich countries [...] that may have a substantial impact on human development. It is just that the HDI and GDI are too crude to pick up these more subtle inequalities.

(Bardhan and Klasen, 2000: 194)

The implications of these concerns become clear when one compares the Nordics on a neglected indicator such as parental leave. Norway and Sweden have adopted policies that push fathers to take parental leave, while Denmark has taken a very different approach, with a weaker institutionalization of leave conditions and greater focus on individual freedom for each family. In Denmark, the focus is less on gender equality and more on children's rights (Borchorst and Siim, 2008). However, the highly aggregated scores above do not provide this level of understanding or nuance: Denmark significantly outperforms Sweden in the GDI but not on this dimension of gender development.

Likewise, the Gender Empowerment Measure has been criticized on measurement grounds. The index includes formal measures of women's empowerment: share of parliamentary seats; share of administrative, professional, technical and managerial positions; and share of earned income. Yet, even though the index 'captures some aspects of female agency, it is questionable how well the GEM measure at present fully captures economic and political power held by women and their role in the development process' (Bardhan and Klasen, 1999: 1000). This concern, however, is more relevant to those countries with strong use of quotas in formal representative bodies with little power, such as China and Cuba. A more relevant critique for the Nordics is that there are reliability challenges in comparing industries across countries and that indexes do not take into account strong internal regional disparities within countries (Pillarisetti and McGillivray, 1998: 202; Kirkebø and Langford, 2019). 
Second, the choice of data has been subject to critique. A common element in global indexes is expert panels or survey data (Kirkebø and Langford, 2019). The Global Gender Gap Index from the World Economic Forum is a case in point, as it includes surveys of executives alongside statistics from international organizations. The risk is that images of certain countries become reinforcing. In the Global Gender Gap Index, the Nordics score very highly, and their performance is particularly strong on two of the five areas measured: politics and economic participation. Such an index allows Denmark to rank quite highly, yet other long-standing indexes show Denmark lagging significantly behind on pay gap and participation. In relation to equal pay, Denmark is ranked at 52, whereas it is ranked 102 in relation to female participation in business (Kolberg, 2020). Indeed, less than $10 \%$ of businesses have a female leader, with a greater number being led by men called Lars (Knudsen, 2018).

Third, indexes can be interpreted in problematic ways, especially through the conflation of relative and absolute performance. Rankings do exactly what the term suggests - they rank; they do not provide any information about whether the level of performance is satisfactory. In practice, however, they are often interpreted in absolute terms. This unintended consequence was noted early with the Gender Development Index: 'As expected, no country has a GDI as high as its HDI, suggesting that all countries have some gender gaps in at least one of their components' (Bardhan and Klasen, 1999: 989).

\section{The role and power of global gender indexes}

Moving beyond statistical questions, the potential power of indexes on Nordic gender exceptionalism discourse is arguably palpable. To study this, we performed a quantitative media content analysis of the role of indexes in strengthening gender exceptionalism. Using the global m360 media retrieval service, we identified 6,809 articles in English-speaking online media containing the words 'Nordic' and 'index' in the period between January 2012 and 30 June 2018. The most commonly mentioned thematic words - which are the subject of indexes or objects of substantive comparison - are listed in Figure 10.3. Two of the most common themes are the performance of the business and pharmaceutical sectors, but a range of socio-economic themes also feature strongly, such as happiness, work, technology and war. What is most striking, though, is the prominence of gender. 'Women and girls' are the fourth most-mentioned, and 'gender' the sixth most-mentioned.

How are we to interpret these results? A decision tree analysis of linked phrases and words shows not only that gender is prominent, but also how global indexes in general power the discourse of Nordic gender exceptionalism. On the one hand, many media articles refer to specific genderspecific indexes. One newspaper article discussing this index, on female 


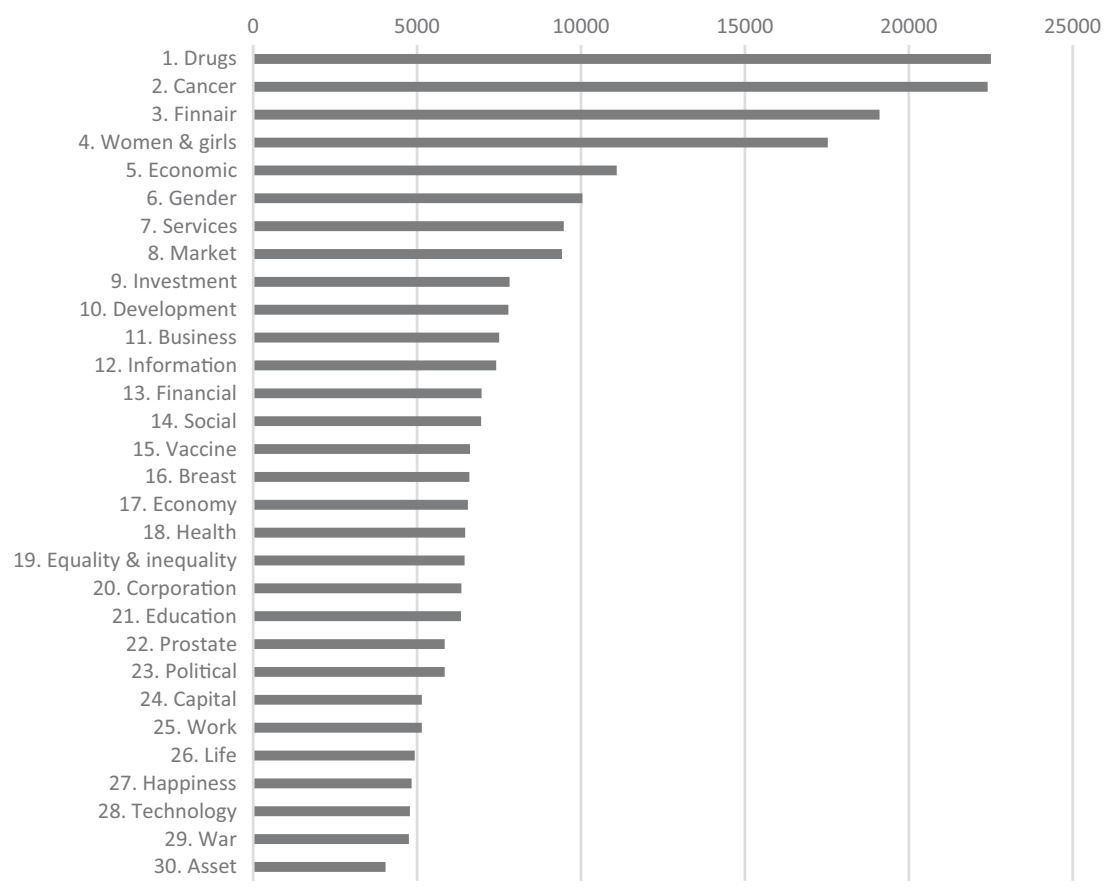

Figure 10.3 Ranking of thematic words in Nordic and index media content analysis (by counts).

participation in the technology industry, contains the following discussion of a low performer:

[India's Global Gender Gap Index ranking has declined with] a widening of its gender gaps in Political Empowerment... healthy life expectancy and basic literacy.

And then a high performer:

[Iceland] has closed more than $87 \%$ of its overall gender gap... the first in the world to [make] 'paying men more than women' illegal.

On the other hand, many of the decision trees concern other non-gender indexes, yet still address gender. When this occurs, the high performers (often some Nordic countries) are mentioned together with low or other performers. For example, looking at a specific article, which discusses a global index on competitiveness, we see one way in which gender enters:

The 2018 Global Talent Competitiveness Index benchmarks how countries and cities expand, attract and retain talent.... The Nordic countries 
score remarkably well on most variables related to collaboration, internal openness, social mobility and gender equality but they struggle in external openness..... Norway again tops the index.

(NBR, 2018, emphasis added)

This broader focus on gender across many different indexes reveals a simple but powerful phenomenon: There is a gender dimension to almost all datasets. Indicators are often disaggregated by gender - as it is the easiest background characteristic to measure (a binary in most cases) and has been measured for a long time. Alternatively, as in the example of the Global Talent Competitiveness Index above, a gender dimension is included in the index. The result is that, in the discussion of virtually any index, there is a good chance that countries that perform well or poorly on its gender dimension are mentioned. Thus, what is powerful for the purposes of discourse is not just the specific gender indexes but gender performance in all indexes.

Moving beyond the role of indexes in diffusing and strengthening Nordic gender exceptionalism, some comments on the broader power of indexes on shaping our understanding of Nordic gender equality are warranted. As foreshadowed, the power of gender indexes to mobilize contrasting images of the Nordics is also apparent. Like Kirk (2019), Teigen and Skjeie (2017) place Denmark consistently below the other Nordic countries on most indicators, and identify Sweden as the frontrunner. Yet, other indexes show Denmark performing at a level that is just as high as that of the other Nordic countries. This illustrates how the Nordic model may be sustained even when there is a controversy related to the performance of some of the countries associated with the model.

Equally, there is the power of indicators in driving causal explanations. For example, examining national statistics from the Nordic countries in the 1990s, Skevik (2006: 260) points out that Nordic mothers raising their child alone are less likely to live in poverty than other mothers in a similar situation. ${ }^{9}$ Skevik attributes this to the Nordic approach to parental leave and the high degree of employment for women, although the analysis does not indicate a causal relationship between the two. Frazer and Marlier (2007) come to a similar conclusion as Skevik, pointing to inclusive family policies, including parental leave, as an explanation for comparatively less family poverty in the Nordic countries. Reflecting on statistics measuring division of labour in the home, Lister (2009: 261) argues, however, that the belief in the effectiveness of policies among the Nordics weighs heavier than the actual effect of the policies.

However, the effect is not only global - it may also be national. The branding of nations may be intentionally or unintentionally directed at a domestic audience (Moss and Langford, 2020). Towns (2002) argues that the gender-equality identity created and branded in Sweden has divisive effects. She argues that "this equality discourse has also become implicated in a new inequality, namely the hierarchical categorization of the population of Sweden into "Swedes" and "immigrants" (Towns, 2002: 157). The gendered 
effects of national self-understanding can also be evident in discussions of LGBT rights. Populist critiques of migrants have politicized the conservatism of certain migrant communities on the question of sexual minorities culminating in the emergence of a homonationalist discourse (Puar, 2007). Interestingly, Freude and Bosch (2020) find that Sweden has the fourthlargest homonational grouping in its population - with a high correlation between LGBT tolerance and racism.

This 'dark side' of index success deserves greater attention. Do positive rankings have a negative effect on willingness to impose new regulation or policy to tackle gender issues, given the comparative achievement of the Nordics, or provide easy ammunition for populist critiques? Moreover, in a global perspective, does the possibility of influencing policy development lead to an overplaying of regional success, as we see, for example, when Norwegian officials cooperate with EU officials to develop European policies on prostitution and gender equality, branding and conceptualizing the Nordic model of criminalisation of sex purchase in the process (Langford and Skilbrei, 2021)?

\section{Conclusion}

This chapter has argued that contemporary understandings of Nordic gender exceptionalism cannot be divorced from the role of global indexes. These indexes are regularly called upon and mobilized to justify images and imaginaries of gender exceptionalism in the Nordic region, as others have also noted in this book. This chapter has argued that global indexes may contribute to the shaping of Nordic gender exceptionalism in two discrete ways.

The first is that the prominence of gender in the reporting of indexes (both general and gender-specific) creates and maintains a 'background' discourse ${ }^{10}$ on Nordic exceptionalism. This is driven by the inherent forces within statistical constructions: Gender is easily operationalizable and thus easily included as an element in an index or a background attribute for disaggregation. It is also shaped by the structure of indicator discourse. Index narratives commonly include high and low performers, or those improving or worsening their position. Thus, the index discourse is arguably constantly skewed towards the production of a narrative on Nordic gender exceptionalism.

The second is that global indexes have created a new discourse for gender exceptionalism: policy characteristics and achievements are often expressed quantitatively in competitive and ranked form. Parsing these developments, this chapter has sought to shed light on the statistical underpinnings and limitations of the indexes and their latent authority in policy discussions - in other words, their constructive and constituent power. It is argued that some caution should be exercised in their naive reception and use. The simplification and resilience of gender indexes occlude a range of gender-equality paradoxes in the Nordic region and the politics behind their mobilization. 


\section{Notes}

1 See Green $(2016,2017)$.

2 See, for example, Wiking (2016); see Higgins (2016) for a list of books on hygge.

3 See https://www.hyggelife.com/.

4 See https://www.hygge.nyc/.

5 For the branding of Copenhagen, see Lubanski (2019); for the ranking, see Equal Measures 2030 (2019).

6 A full overview of indexes and their classification is found online at https:// www.uio.no/english/research/strategic-research-areas/nordic/research/ research-groups/nordic-branding/research-projects/dataset-of-indexes.html. As this chapter focuses on the Nordic countries, indexes that do not include a majority of the Nordic countries have been excluded from the analysis. Most of the Nordic countries are included in all indexes, but Iceland appears in fewer than the rest.

7 Social indexes include those that focus on social issues - that is, social justice, religion, child survival, happiness and hunger. Economic indexes measure degree of globalization, innovation, tax and finance. Infrastructure includes access to internet, connectedness and access to data. Governance indicators deal with issues of democracy, freedom, rule of law and peace. There are comparatively fewer global contributions and global perspectives indexes. For the former, we have included commitment to philanthropy and development; for the latter, passport power and good country/nation brands. The last category on gender includes indexes that have a gender perspective, measuring development, empowerment and gender gaps.

8 No states were directly responsible for their production even though they were included as possible actors in the initial coding manual.

9 In another study, Skevik (2006b: 225) compares poverty in the Nordic countries to that in the UK and Netherlands. In the Nordics, the poverty rate is between $5 \%$ and $17 \%$, while the rate for the UK and the Netherlands is $40 \%$.

10 See Schmidt (2008: 304) on discursive institutionalism and the power of changing ideas in shaping 'background ideational abilities'.

\section{References}

Andrews M (2008) The good governance agenda: Beyond indicators without theory. Oxford Development Studies 36(4): 379-407.

Angell SI and Mordhorst M (2015) National reputation management and the competition state: The cases of Denmark and Norway. Journal of Cultural Economy 8(2): 184-201.

Apaza C (2009) Measuring governance and corruption through the worldwide governance indicators: Critiques, responses, and ongoing scholarly discussion. PS: Political Science and Politics 42(1): 139-143.

Aspeli I (2018) Ny, norsk forskning: Det er ganske slående funn i et av verdens mest likestilte land. $V G, 2$ July. Available at: https://www.vg.no/nyheter/innenriks/i/ gPAv1A/ny-norsk-forskning-det-er-ganske-slaaende-funn-i-et-av-verdens-mestlikestilte-land (accessed 9 November 2020).

Bardhan K and Klasen S (1999) UNDP's gender-related indices: A critical review. World Development 27(6): 985-1010.

Bardhan K and Klasen S (2000) On UNDP's revisions to the gender-related development index. Journal of Human Development and Capabilities 1(2): 191-195. 
Barsh RL (1993) Measuring human rights: Problems of methodology and purpose. Human Rights Quarterly 15: 87-121.

Beaumont P and Towns A (2018) All these rankings yet the bodies keep piling up: Rankings, public diplomacy and the soft-power industrial complex. Paper presented at 12th Pan-European Conference on International Relations, Prague, 12-15 September.

Borchorst A and Siim B (2008) Woman-friendly policies and state feminism: Theorizing Scandinavian gender equality. Feminist Theory 9(2): 207-224.

Bredeveien JM (2018) Verdens mest likestilte land - bare ikke i næringslivet. Dagsavisen, 6 September. Available at: https://www.dagsavisen.no/nyheter/innenriks/ verdens-mest-likestilte-land-bare-ikke-i-neringslivet-1.1198175 (accessed 9 November 2020).

Browning C (2007) Branding Nordicity: Models, identity and the decline of exceptionalism. Cooperation and Conflict 42(1): 27-51.

Byrkjeflot H, Langford M and Kirkebø TL (2018) Indexes and Nordic exceptionalism. Paper presented at the workshop 'Nordic Models in the Age of Populism', Boston University, 27-28 September.

Cooley A and Snyder J (eds) (2015) Ranking the World. Cambridge: Cambridge University Press.

Davies W (2015) Spirits of neoliberalism: 'Competitiveness' and 'wellbeing' indicators as rival orders of worth. In: Rottenburg R, Merry SE, Park S-J and Mugler $\mathrm{J}$ (eds) The World of Indicators: The Making of Governmental Knowledge Through Quantification. Cambridge: Cambridge University Press, 283-306.

Davis K, Kingsbury B and Merry SE (eds) (2012) Governance by Indicators: Global Power Through Classification and Rankings. Oxford: Oxford University Press.

Ellingsæter AL and Leira A (2006) Introduction: Politicising parenthood in Scandinavia. In: Ellingsæter AL and Leira A (eds) Politicising Parenthood in Scandinavia: Gender Relations in Welfare States. Bristol: Policy Press, 1-24.

Equal Measures 2030 (2019) Harnessing the power of data for gender equality: Introducing the 2019 EM2030 SDG Gender Index. Available at: https://data. em2030.org/wp-content/uploads/2019/05/EM2030_2019_Global_Report_ENG. pdf (accessed 9 November 2020).

Erkkilä T and Piironen O (2018) Rankings and global knowledge governance. In: Erkkilä $\mathrm{T}$ and Piironen $\mathrm{O}$ (eds) Rankings and Global Knowledge Governance. Cham: Palgrave Macmillan, 219-249.

Frazer H and Marlier E (2007) Tackling child poverty and promoting the social inclusion of children in the EU. September. Available at: https://ec.europa.eu/ employment_social/social_inclusion/docs/experts_reports/synthesis1_2007_ en.pdf (accessed 30 December 2020).

Freude L and Bosch NV (2020) Homonationalism in Europe? A quantitative comparison of the values of Europeans. Sexuality \& Culture 24: 1292-1314.

Gates B (1975) Knowledge management in the technological society: Government by indicator. Public Administration Review 35(6): 589-593.

Green P (2016) Move over, Marie Kondo: Make room for the hygge hordes. New York Times, 24 December. Available at: https://www.nytimes.com/2016/12/24/fashion/ wintering-the-danish-way-learning-about-hygge.html (accessed 9 November 2020).

Green P (2017) Hygge gets heave-ho as Swedes, Norwegians join the fun. New York Times, 14 December. Available at: https://www.nytimes.com/2017/12/14/style/ 
lykke-is-the-new-hygge-scandinavian-lifestyle-books.html (accessed 9 November 2020).

Higgins C (2016) The hygge conspiracy. The Guardian, 22 November. Available at: https://www.theguardian.com/lifeandstyle/2016/nov/22/hygge-conspiracy-denmarkcosiness-trend (accessed 9 November 2020).

Kelley JG and Simmons BA (2015) Politics by number: Indicators as social pressure in international relations. American Journal of Political Science 59(1): 55-70.

Kirk L (2019) Denmark falls behind in gender-equality ranking. EU Observer, 18 December. Available at: https://euobserver.com/nordic/146958 (accessed 19 October 2020).

Kirkebø TL and Langford M (2019) Children's rights indexes: Measuring Norway's performance. In: Langford M, Skivenes M and Søvig K (eds) Children's Rights in Norway: An Implementation Paradox? Oslo: Universitetsforlag, 42-104.

Kirkebø TL, Langford M and Byrkjeflot H (2019) Indexes and Nordic exceptionalism. Paper presented at the Law \& Society Association Annual Conference, Boston, MA, June.

Knudsen JS (2018) Multinational firms. Paper presented at the workshop 'Nordic Models in the Age of Populism', Boston University, 27-28 September.

Kolberg M (2020) Likestillingsministeren i Danmark har også ansvar for fisk, matproduksjon og nordisk samarbeid. NRK, 22 October. Available at: https:// www.nrk.no/urix/likestillingsministeren-i-danmark-har-ogsa-ansvar-for-fisk_matproduksjon-og-nordisk-samarbeid-1.15209106 (accessed 13 November 2020).

Landman T (2004) Measuring human rights: Principles, practice and policy. Human Rights Quarterly 26: 906-931.

Langford M and Schaffer JK (2014) The Nordic human rights paradox: Moving beyond exceptionalism. University of Oslo Faculty of Law Research Paper No. 2013-25. Available at: https://papers.ssrn.com/sol3/papers.cfm?abstract_ $\mathrm{id}=2275905$ (accessed 30 December 2020).

Langford M and Skilbrei ML (2021) Branding the Nordic model of prostitution policy. In: Byrkjeflot H, Pedersen K, Mordhorst M and Mjøset L (eds) The Making and Circulation of Nordic Models. Abingdon: Routledge. Forthcoming.

Lister R (2009) A Nordic Nirvana? Gender, citizenship, and social justice in the Nordic welfare states. Social Politics 16(2): 242-278.

Lubanski N (2019) Denmark is world leader in gender equality. Copenhagen Capacity, 4 June. Available at: https://www.copcap.com/news/denmark-is-world-leaderin-gender-equality (accessed 2 November 2020).

Mau S (2020) Numbers matter! The society of indicators, scores and ratings. International Studies in Sociology of Education 29(1-2): 19-37.

Mennicken A and Espeland WN (2019) What's new with numbers? Sociological approaches to the study of quantification. Annual Review of Sociology 45: 223-245.

Moss SM and Langford M (2020) Militæraktivisme brandet som fredsaktivisme? Norges kampanje for en plass i FNs sikkerhetsråd. Internasjonal Politikk 78(3): 1-14.

NBR (2018) New Zealand ranked for talent and inclusive development. 25 January. Available at: https://www.nbr.co.nz/opinion/davos-2018-new-zealand-rankedtalent-and-inclusive-development (accessed 13 November 2020).

Nordic Council of Ministers (2006) Nordic Gender Equality Programme 2006-10. Copenhagen: Nordic Council of Ministers. 
Pillarisetti J and McGillivray M (1998) Human development and gender empowerment: Methodological and measurement issues. Development Policy Review 16(2): 197-203.

Porter TM (1995) Trust in Numbers: The Pursuit of Objectivity in Science and Public Life. Princeton, NJ: Princeton University Press.

Puar J (2007) Terrorist Assemblages: Homonationalism in Queer Times. Durham, NC: Duke University Press.

Ringel L, Brankovic J and Werron T (2020) The organizational engine of rankings: Connecting 'new' and 'old' institutionalism. Politics and Governance 8(2): 36-47.

Rosga A and Satterthwaithe M (2009) The trust in indicators: Measuring human rights. Berkeley Journal of International Law 27: 253-315.

Schmidt V (2008) Discursive institutionalism: The explanatory power of ideas and discourse. Annual Review of Political Science 11: 303-326.

Skevik A (2006) Lone motherhood in the Nordic countries: Sole providers in dualbreadwinner regimes. In: Ellingsæter AL and Leira A (eds) Politicising Parenthood in Scandinavia: Gender Relations in Welfare States. Bristol: Policy Press, 241-264.

Teigen M and Skjeie H (2017) The Nordic gender equality model. In: Knutsen O (ed.) The Nordic Models in Political Science: Challenged, but Still Viable? Bergen: Fagbokforlaget, 125-147.

Towns A (2002) Paradoxes of (in)equality: Something is rotten in the gender equal state of Sweden. Cooperation and Conflict 37(2): 157-179.

Wiking M (2016) The Little Book of Hygge: The Danish Way to Live Well. London: Penguin. 


\title{
Afterword \\ Gendering the brand?
}

\author{
Halvard Leira
}

What is the role of gender and gender equality in branding the Nordic states? This is a question of obvious political significance and academic interest. In setting out to answer it, the editors of this collection have had high ambitions - ambitions that have been met over the preceding pages, in part by rephrasing the question. As demonstrated in the different chapters of this book, we should probably rather ask, 'What roles do gender and gender equality play in the relations between the Nordic states and the world?' The answers provided are far from straightforward, and, as with all good intellectual answers, they bring out additional puzzles. Over the next few pages, I will highlight some of these puzzles. I would nevertheless like to preface my concluding comments by emphasizing that these puzzles arise from a set of tightly argued, conceptually informed and empirically strong chapters. This collection demonstrates in full the benefits of bringing together a diverse team of scholars to study one fairly specified topic from a number of different angles.

To better be able to evaluate the practices discussed in this volume, we need to engage with the basic conceptual frameworks, starting with the notion of place branding, which is a fairly new concept in the social sciences. Its attraction lies in its capacity for increasing our understanding of how cities, regions and states seek to create affective connections between places and people. In its most basic sense, place branding is about creating a bond between a place and consumers willing to pay to experience and/or share in the perceived qualities of said place. It is also a concept based on a market understanding of competition: one place's gain is most likely some other place's loss. Typically associated with efforts to attract tourists, entrepreneurs and investments, it has recently also been associated with states' efforts to increase influence or improve reputation (Dinnie, 2015). At that stage, the concept comes in touch with other ways of conceptualizing state behaviour or capacity directed at other countries and populations, such as public diplomacy and soft power. The boundary between place branding and public diplomacy in particular is blurry (but see Szondi, 2008; Cull, 2019). To be very crude, one could argue that public diplomacy is about winning hearts and minds, while nation-branding is about winning the wallet. 
What is often lost in conceptual discussions like this, however, is the simple question of why? Why, beyond profit or affection, do states want to be seen and recognized?

One potentially productive way of framing the debates about nationbranding and public diplomacy is to consider them both subsumed under the broader motivations of status, prestige and reputation. Going back to Hobbes, it has been assumed that states seek not only power and wealth, but also status. Recent theoretical discussions have led to an appreciation of status as an autotelic goal: it does not have to be explained as subservient to any other goal, it is its own goal. ${ }^{1}$ While status has often been associated with great-power aspirations and conflicts, there are many reasons why one would assume status to be even more important to small powers and middle powers (Wohlforth et al., 2018). For those states, moral authority, rather than brute force, is the sought-after source of status. And, to return to the case at hand, gender equality has become one of the many dimensions along which moral authority at the state level is conferred (Towns, 2010).

Reframing the questions about gender and gender equality in the external activities of the Nordic countries in terms of status has at least three immediate advantages. The first advantage is that status expands the scope and reduces the reliance on agency. Analysing processes in the light of public diplomacy and nation-branding requires a strategic outlook, active agency and an underlying premise that states are pursuing specific actions (like promoting gender equality) to achieve something else (like increasing profits). The analytical lenses of status and status-seeking, on the other hand, allow us to make sense of less explicitly goal-oriented activities and mixed motivations. ${ }^{2}$ The second advantage is that status, as currently perceived, is social and relational, where nation-branding and, to some extent, public diplomacy are unidirectional. A status lens highlights complexity at home and abroad. On the one hand, it emphasizes how domestic politics can shape status-seeking and how the domestic resonance of status-seeking matters to its likelihood of success (Beaumont, 2020). On the other hand, it leads our attention to the external recognition of status, how it can be associated with circles of recognition, club membership and relative ranking (Røren, 2020), and also how there is a marked difference between formally equal-status relationships and relationships more in the teacher-pupil mould. The third advantage is reducing anachronism. Public diplomacy and nation-branding are relatively new concepts of both practice and analysis. Applying them to activities from before the middle of the twentieth century can create interesting juxtapositions but can also lead us to misguided analyses. Status and reputation, on the other hand, have been acknowledged motivations of state behaviour for centuries. As was noted in the Norwegian parliament in 1864, for smaller states, 'honour and prestige are even more important than for the greater powers' (cited in Leira, 2015: 22).

Turning to the preceding chapters, status does unlock a number of what might seem puzzling insights if the latter are viewed solely through the 
lens of nation-branding. To start with a combination of all of the points above, reforms pushing gender equality and other gendered topics were not originally conceptualized for external strategic aims. On the contrary, as Larsen demonstrates in her chapter, it took American activists to make the case for the Nordics as pioneers. Gender equality was not originally conceived as a branding strategy. It was something that these states engaged in, which gradually became part of national identity/self-images and much later seemed to possibly be usable in public diplomacy/nation-branding to increase status/prestige. And it is not as if these states were not statusconscious at the time when gender equality was first put on the agenda. When one of the Norwegian foreign policy intellectuals discussed a future foreign policy in the run-up to Norwegian independence in 1905, he wanted to emphasize international law, not necessarily to stake a claim as a 'pioneering people', but to emphasize, 'it will be our honour to have partaken in creating a new age and an era of peace among men' (cited in Leira, 2013: 344). As small states, the Nordics wanted to be recognized; gender equality was just not one of the fields that they considered to offer such recognition. In recent years, however, policies such as the Swedish rape legislation have been crafted with at least some consideration for the example to be set, as demonstrated by Skilbrei. But even while the Nordics are eager to promote their high ranking on different gender performance indexes, as discussed by Kirkebø, Langford and Byrkjeflot, it is not obvious that this self-perceived and index-reinforced exceptionalism has any instrumental consequences beyond status affirmation.

Many of the chapters touch upon the domestic side of status-seeking. To be effective, status-seeking must be built around something that the domestic audience acknowledges as salient to the self-image. While gender equality is certainly part of the self-image of the Nordic states, it is expressed in different ways and also 'usable' for diplomats in different ways. As Jezierska and Towns demonstrate, the place of gender in the different national narratives is, so to speak, 'on brand' (with Norway focusing on nature, Sweden on progress, Finland on function, and so on). Domestic politics also spill over into how the state projects outwards. While it is, for instance, relatively uncontroversial for a centre-left Swedish government to engage in a 'feminist' foreign policy, for a similar Norwegian government such a label would not fly domestically. There, 'gender equality' is the commonly accepted frame. As explored in different ways in the chapters by Moss and by Skjelsbæk and Tryggestad, similar hesitations influence how diplomats are able to utilize gender issues. To use the Norwegian case as an example, it seems that, in diplomatic practice, the self-identity as a 'peace nation' trumps the selfidentity as gender-progressive.

Turning to the outside, it becomes even more obvious how gender and gender equality have seldom been about branding at all. As Ginalski demonstrates, the Nordic policies on gender quotas (which have never been pushed hard as examples by the Nordic states) have been used actively in 
Swiss debates. This illustrates on one hand the lack of Nordic control over foreign uptake of their policies, on the other the importance of how the Nordics have pursued different policies. The lack of control over uptake is also obvious in how sexual liberation at home has been perceived as promiscuity abroad. In general, the Nordics have been gender-progressive, but in different ways, leading them to be 'usable' in debates and as examples in different ways. The lack of control is also obvious in what we could call the 'boomerang effect', or the feedback loop of claiming status as a pioneer, as demonstrated by Hellum. Promoting a norm like gender equality globally might come back to challenge you at home when global norms move beyond your position. At that stage, as Erlingsdóttir discusses, internal actors might use outside perceptions to change domestic policy. The perceived foreign association of Iceland with gender equality could be utilized domestically to push for even further equality.

In more indirect ways, the different chapters also demonstrate the importance of a differentiated approach to the analysis of status-seeking. The Nordic countries generally form each other's most important circle of recognition. This implies that relative ranking within the group, albeit friendly, is paramount (Røren, 2020). With Sweden leading the way with a feminist foreign policy, the other states might just decide to focus elsewhere. The regional dynamics also imply that gender issues might not be seen as 'usable' for status purposes by the individual states. Moving beyond the region and approaching the rest of the world, as discussed by Holst and Teigen, there is a distinct teacher-pupil dynamic in play in how the Nordics push the gender agenda. Even though diplomats might want to tone down the notion of 'moral superiority', the states have been reluctant to accept that other states have advanced the agenda of gender equality beyond the Nordic example.

Overall, this volume demonstrates in detailed and varied ways how gender issues and gender equality have been interweaved with how the Nordic states present themselves to the world. Being gender-equal is obviously part of the self-image of the Nordic states, and it also matters for how they interact with the world. Self-consciousness of being pioneers matters to regional identitybuilding and branding, but is on the other hand not necessarily something the individual states can mobilize to increase status. Paradoxically, the Nordic brand has been thoroughly gendered, but, for status-seeking purposes, gender has proved surprisingly unhelpful. Perhaps if everyone knows that you are the most gender-equal countries in the world, there is little to gain by demonstrating that you have become even more equal?

\section{Notes}

1 Structuring the discussion, we could then start from the assumption that states care about status (or prestige/image/reputation). One of the ways in which states have tried to increase or retain their status over the last decades is through public diplomacy. One specific form of public diplomacy (or possibly an activity that overlaps to some degree with public diplomacy) is place branding. 
2 Status could, for instance, help to make sense of the promotion of gender equality as a case of a combination of utilitarian norm-diffusion and self-interested status-seeking.

\section{References}

Beaumont P (2020) The Grammar of Status Competition: International Hierarchies as Domestic Practice. PhD thesis, Norwegian University of Life Sciences.

Cull NJ (2019) Public Diplomacy: Foundations for Global Engagement in the Digital Age. Cambridge \& Medford, MA: Polity.

Dinnie K (2015) Nation Branding: Concepts, Issues, Practice, 2nd edn. London \& New York: Routledge.

Leira H (2013) 'Our entire people are natural born friends of peace': The Norwegian foreign policy of peace. Swiss Political Science Review 19(3): 338-356. doi:10.1111/ spsr.12044.

Leira H (2015) The formative years: Norway as an obsessive status-seeker. In: De Carvalho B and Neumann IB (eds) Small State Status Seeking: Norway's Quest for International Standing. Abingdon: Routledge, 22-42.

Røren P (2020) Socializing Status in World Politics: Collectives, Orders, and Recognition. PhD thesis, University of Southern Denmark.

Szondi G (2008) Public diplomacy and nation branding: Conceptual similarities and differences. Discussion Papers in Diplomacy. The Hague: Clingendael. Available at: https://www.clingendael.org/sites/default/files/pdfs/20081022_pap_in_dip_ nation_branding.pdf (accessed 10 November 2020).

Towns AE (2010) Women and States: Norms and Hierarchies in International Society. Cambridge: Cambridge University Press.

Wohlforth WC, De Carvalho B, Leira H and Neumann IB (2018) Moral authority and status in international relations: Good states and the social dimension of status seeking. Review of International Studies 44(3): 526-546. doi:10.1017/ S0260210517000560. 

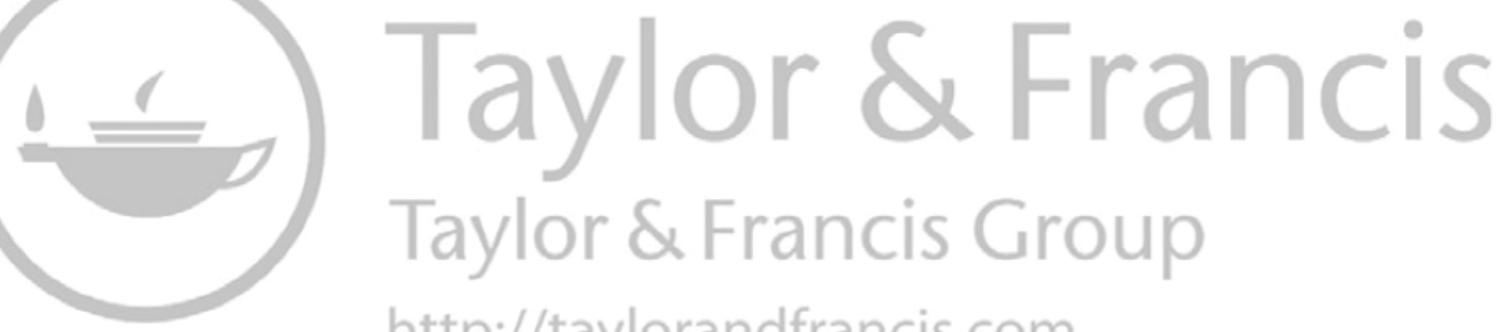

http://taylorandfrancis.com 


\section{Index}

Note: Italic page numbers refer to figures and page numbers followed by "n" refer to notes

Action Plan for Women's Rights and Gender Equality in Development Cooperation (Norway) 177, 183

Act on Equality between Women and Msen (Finland) 175

Act on Equal Pay (Denmark) 175

Act on Equal Treatment (Denmark) 175

Act on Equal Treatment in the Labour

Market (Denmark) 175

Act on Violence Against Women 76 anti-discrimination law in Nordic countries 174-176

Australia 20, 24, 26, 31, 121

Beijing Declaration 103

branding: brand equity 63 ; gendered national rebranding 96-98; nation-branding 2, 39-57, 153

business: corporate boards and gender equality 134 ; rise of gender quotas in $135-138$

'business masculinity' 137

CEDAW Committee 174; and Nordic countries 176; on Nordic countries difference between national and international gender policies 177-179; Nordic countries resistance to genderspecific anti-discrimination laws 184-187; Nordic countries resistance to incorporation of CEDAW into national law 179-184; Nordic genderequality model 187-188

'Centenary of Icelandic Independence and Sovereignty' 54

Charter of Fundamental Rights 157
Cold War 10, 102

Commission on the Status of Women (CSW) 153

Confederation of Danish Industry 43

Convention on the Elimination of All Forms of Discrimination Against Women (CEDAW) 9, 10n1, 173-174, 175; Article 2 of 179-180

Convention on the Rights of the Child 181

Copé-Zimmerman Law 137, 148

corporate boards and gender equality 134

Council for the Promotion of Sweden 48

Council of Europe 103

COVID-19 pandemic 97

Danish Ministry of Foreign Affairs 57n2

Danish Women's Suffrage Society 26

Denmark 1, 121-122; 'Action Plan for the Global Marketing of Denmark' 42; Act on Equal Pay 175; Act on Equal Treatment in the Labour Market 175; equality legislation 155; Equal Rights Act 175; gender equality 191; gender quotas in 138; Global Gender Gap Index 199; trusting 42-44

Denmark.dk 42-43, 52, 56

Discrimination Act (Sweden) 175

\#DontTravelToSweden 80

Ease of Doing Business Index 193

Egon Zehnder 136, 138

Equality and Anti-Discrimination Act 175 
equality legislation: Act on Equality between Women and Men 175; Act on Equal Treatment in the Labour Market 175; Denmark 155, 175; Gender Equality Act 136, 160, 162, 175, 183; Gender Equality and AntiDiscrimination Acts 107n20, 175, 185; Iceland 155; Norway 155, 156-158; Sex Equality Act 175; Sweden 155

Equal Rights Act (Denmark) 175

European Convention on Human Rights 181

European Court of Justice 158

European Economic Area agreement 162

European Free Trade Association Surveillance Agency (ESA) 158

Federal Commission for Women's Issues 135

female quotas, corporate boards: Norway 137, 141, 147; Sweden 137; in Switzerland 135, 140-142; in Switzerland after 2007-2008 financial crisis 142-144

financial crisis: global 91

Finland 1, 20, 121-123; Act on Equality between Women and Men 175; functional 51-54; revolutionary 27-29

Finland Country Image Communications Workbook (Anderson) 51

Finland.fi 52

Finland Promotion Board 51-52

Finland's Country Branding Strategy 201752

Finnish Labour Party 21

Finnish Women's Rights Federation 21

Food and Agriculture Organization (FAO) 161

Gender Development Index (GDI) 192, 198

Gender Empowerment Measure (GEM) 198

Gender Equality Act (Norway) 136, 162 , 175, 182, 186-187

'Gender Equality in Sweden' 49-50

Gender Equality Ombud (Norway) 156,182

gender-equality policies: gender balance in decision-making 162-163; gender mainstreaming 160-161; and nationbranding 153-167; work-life balance $158-160$
Gender Equality Tribunal 156

gender exceptionalism 191-202; Nordic 2-4

Gender Inequality Index 192

gender mainstreaming 160-161

gender quotas $168 \mathrm{n} 17$; in business

135-138; in Denmark 138; in Norway

136-137, 141, 147; Sweden 137;

Switzerland 135, 140-144

Global Gender Gap Index 191, 199

global gender indexes 196-199, 197; role and power of 199-202

global performance indexes 194

Group of Experts on Action against

Violence against Women and

Domestic Violence (GREVIO) 81

HeForShe campaign 103

Hernes, Helga Marie 118-119

Human Development Index (HDI) 191, 193, 198

Human Rights Act (Norway) 180-184

Human Rights Law Commission 181

'hygge' 195

Ibrahimovic, Zlatan 50

Iceland 1, 121, 123; creating 'equal rights paradise' 98-101; elevation of gender equality in foreign policy 101-104; equality legislation 155; gendered national rebranding 96-98; inspirational 54-55; national rebranding and international reification 90-105; overview 90-92; resurrection of women's movement after financial crisis 94-96; sexualized imaginaries of the nation 92-93

Iceland foreign policy: elevation of gender equality in 101-104

Icelandic gender-equality imaginaries 90-105

Iceland.is 54, 55

'Iceland Naturally' marketing programme 54

indexes 193-195; Global Gender Gap Index 191, 199; global gender indexes 196, 196-199, 197; global performance indexes 194; role and power of 199-202

Innovation Norway 45

International Convention on the Elimination of All Forms of Racial Discrimination 181 
International Council of Women (ICW) $14,22-23,31$

International Covenant on Civil and Political Rights 181

International Covenant on Economic, Social and Cultural Rights 181

International Monetary Fund (IMF) 94-95

International Woman Suffrage Alliance (IWSA) 14, 23-26

International Women's Rights Action Watch (IWRAW) 178

International Women's Strike 101

Istanbul Convention 81, 84

Jus Suffragii 26, 27, 30

LGBTQI+ community 99

LGBTQI+ rights 40-41, 44, 49, 55, 104

likestilling 21

Millennium Development Goals 193

Mission for Finland 51

moral superiority, balancing perceptions of $1,2,7,65-66,210$

Muhammad cartoon crisis 41

Napoleonic Wars 19

National American Woman Suffrage

Association (NAWSA) 23

National Queer Association of Iceland 99

Nation Brands Index 5, 195

NATO 102-103

New Zealand 20, 24, 26, 31

NGO FOKUS 178

Ni Una Menos collective 101

Norden $34 \mathrm{n} 1$

Nordic Council of Ministers 13, 32, 39, $56,98,103$

Nordic exceptionalism 2-4

Nordic foreign policy: new arena for 29-31

Nordic gender brand in action 63-65

Nordic gender image 20-22

Nordicity: challenges of, in Scandinavian diplomacy 62-73

'Nordic models' 2, 3, 13, 62, 191, 201, 202

Nordic national action plans (NAPs) $114,120,121-124,132-133$

Nordic Women Mediators (NWM) network 8, 114, 124-127
Norway 1, 20; Common Marriage Act 16; equality legislation 155 , 156-158; foreign policy $114-115$; gender balance in decision-making 162-163; and gender equality 114 , 118-120; gender mainstreaming 160-161; gender quotas in 136-137; as 'haven of gender equality' 1; Human Rights Act 180-184; nation-branding 126; natural 44 48; Norwegianstyle peacebuilding 114-118; peace engagement 116-117; trusting 27-29; work-life balance 158-160; and WPS 113

Norway.no 45

Norwegian Centre for Conflict Resolution (NOREF) 125

Norwegian Centre for Human Rights 182

Norwegian foreign policy 114-115

Norwegian Ministry of Foreign Affairs 153

Norwegian National Suffrage Association (NNSA) 14

Norwegian National Woman Suffragist Association 28

Norwegian National Women's Council 24

Norwegian Public Diplomacy Commission (omdømmeutvalget) 45

Norwegian Public Diplomacy Forum (omdømmeforumet) 45

Norwegian-style peacebuilding 114-118

Peace Research Institute Oslo (PRIO) 125

Promote Iceland Act 54

Ranking and Rating Organizations (RROs) 193

rape 78-81; and legal innovation as nation-branding 75-86

Realpolitik 104

Red Associates 42

Reykjavík Women Leaders Global Forum 104

Scandinavian diplomacy: balancing perceptions of moral superiority 65-66; downplaying Nordic to achieve gender results 66-69; internal Nordic differences and competition 69-70; 
Nordic gender brand in action 63-65;

Nordicity and gender equality in

62-73; Nordics can make the message count $70-71$

sexualized imaginaries of Iceland 92-93

sexual violence 75

social indexes $203 \mathrm{n} 7$

social media 1

'Sri Lanka Unit' 117

state feminism 119, 188n1

Strategy for Women and Gender and

Equality in Development Cooperation (Norway) 177

Study in Norway site 46

Sweden 1, 114; alternative to Norwegian model of quota system 144-147; bad at rape 78-81; Criminal Code 76 ; equality legislation 155 ; feminist foreign policy 121; gender quotas 137 ; harming reputation of genderprogressive 78-81; legislation as inspiration 75-78; nation-branding 126; progressive 48-51; on promoting women in peacebuilding efforts 122 ; rape and legal innovation as nationbranding 75-86; taking charge of image 81-85; Women's Mediation Network 126

Sweden Democrats 79

Sweden's Image Abroad 48

Swedish Code of Corporate Governance 137

Swedish Criminal Code 85

Swedish Institute 48-49

Swedish Ministry for Foreign Affairs (MFA) 40, 62, 116-117

Swedish national identity 19, 79

Swedish Sex Equality Act 175

Swiss Employers Confederation 135, 146-147

Swiss Federal Council 144

Switzerland 134; conservatism in relation to women rights 138-140; debating female business quotas in parliament 140-142; female quotas for corporate boards 134,138
'Team Finland' network 51

ThisisFINLAND 52

Tourism Board of Finland 51

'Track One' 129n12

UN Convention on the Elimination of all forms of Discrimination against Women 157

UN General Assembly 173

UN human rights conventions 157

UN Human Rights Council 104

United Nations 1; Sustainable Development Goals 157, 167n4; World Happiness Report 47

United Nations Development Programme (UNDP) 191

United Nations Gender Equality Studies and Training Programme (GEST) 102

United Nations Industrial Development Organization (UNIDO) 161

universal female suffrage $34 \mathrm{n} 3$

UN Security Council 64, 73n1

UN Security Council Resolution 1325 on Women, Peace and Security 8, 113, 120,121

Visitnorway.com/Visitnorway.no. 40, 45, 48

women: in economic decision-making positions 135; gendered national rebranding 96-98; and Iceland 96-98; participation in central societal arenas 162 ; in peacebuilding efforts and Sweden 122; rights and Switzerland 138-140; see also gender equality

Women, Peace and Security (WPS) agenda 113, 123; and Norway 113; overview 113-114

Women's Alliance 90, 100-102

work-life balance 158-160

World Development Report 2011119

World Economic Forum 98-99; Gender Gap Index 95, 104, 106n8; Global Gender Gap Index 91; Global Gender Gap Report 55

World War I 14, 20, 31 